\title{
Navigation Study, Colorado Locks, Colorado River, Matagorda, Texas
}

Randy McCollum

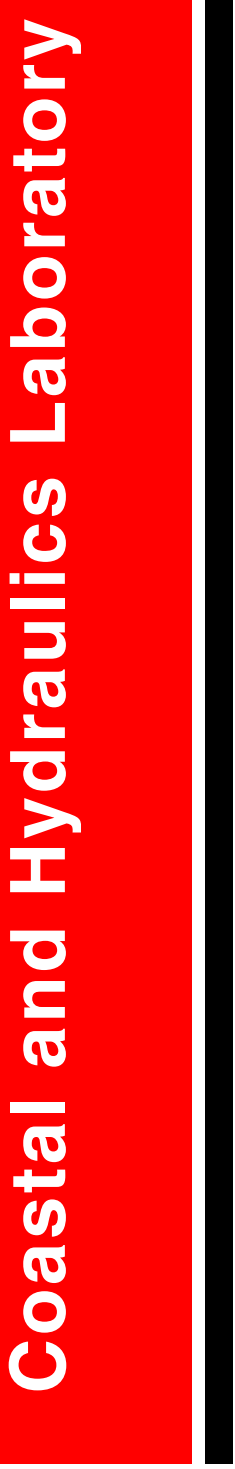

Approved for public release; distribution is unlimited. 
The contents of this report are not to be used for advertising, publication, or promotional purposes. Citation of trade names does not constitute an official endorsement or approval of the use of such commercial products.

The findings of this report are not to be construed as an official Department of the Army position, unless so designated by other authorized documents. 


\section{Navigation Study, Colorado Locks, Colorado River, Matagorda, Texas}

by Randy McCollum

Coastal and Hydraulics Laboratory

U.S. Army Engineer Research and Development Center 3909 Halls Ferry Road

Vicksburg, MS 39180-6199

Final report

Approved for public release; distribution is unlimited 


\section{Contents}

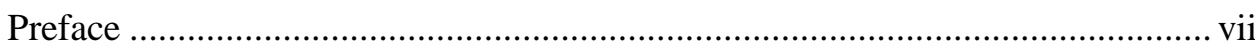

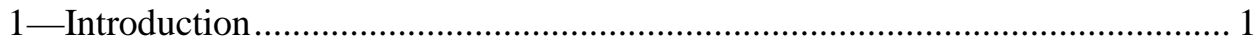

Location and Description of Prototype …................................................... 1

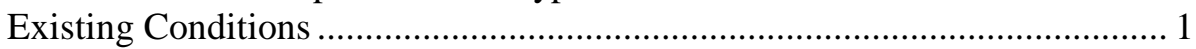

Need for and Purpose of Model Study........................................................ 4

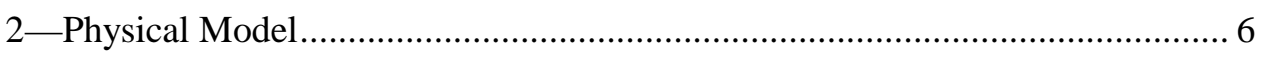

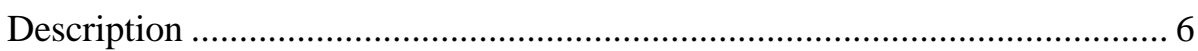

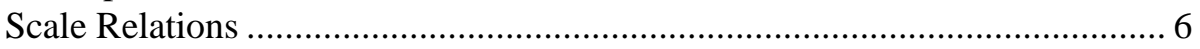

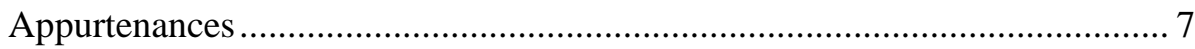

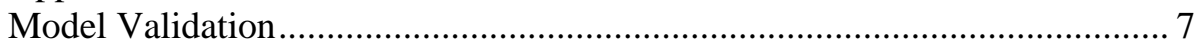

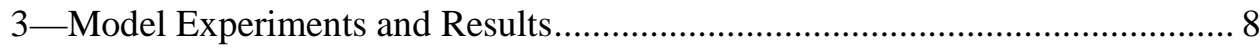

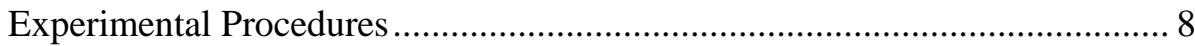

Base Experiments (Existing Conditions) ……............................................ 10

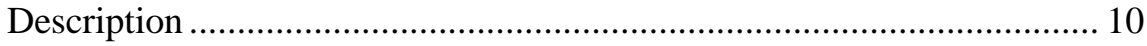

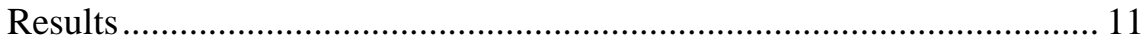

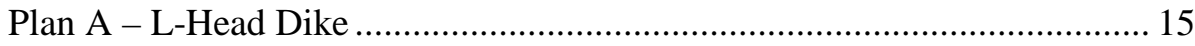

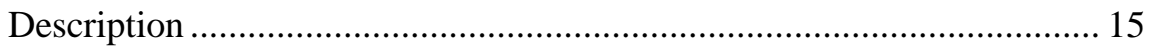

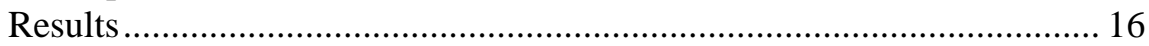

Plan B - Dredging Intersection............................................................... 19

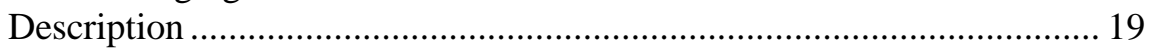

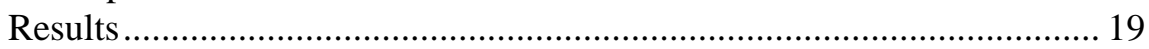

Plan B-1 - Dredging and L-Head Dike .................................................... 21

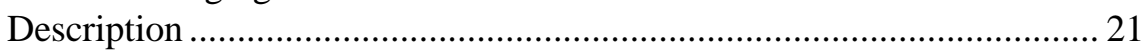

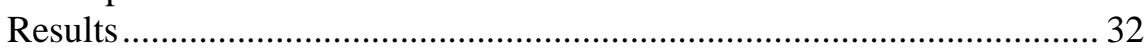

Flow through the East and West Locks ................................................. 34

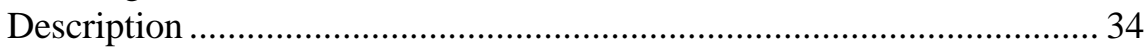

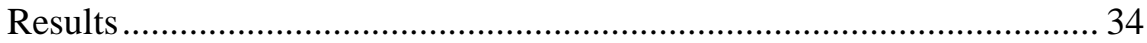

Plan C - Reconstruction of Southwest Corner ……................................. 36

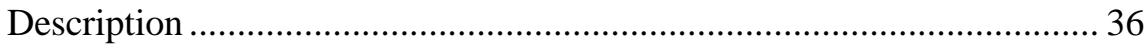

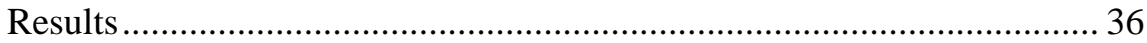

Plan D - Training Structures for GIWW/Bypass Improvements ................... 38

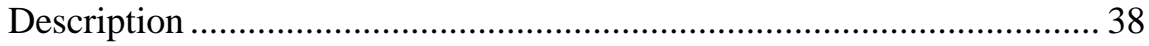




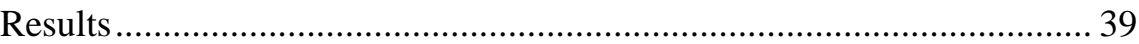

Plan E - Removal of Southeast and Southwest Corners............................... 41

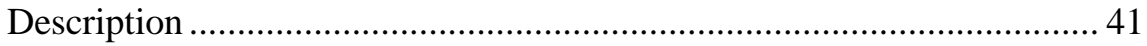

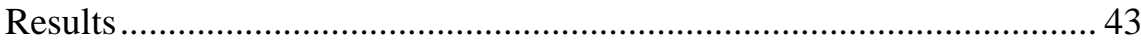

Plan F - Relocation of the Bypass Channel ............................................... 43

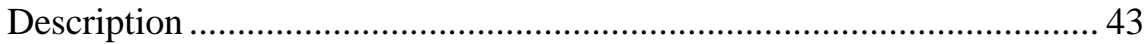

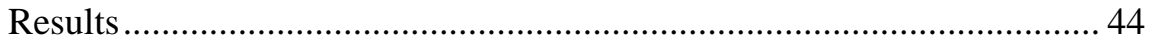

Plan G - Removal of South Gate of West Lock ........................................ 47

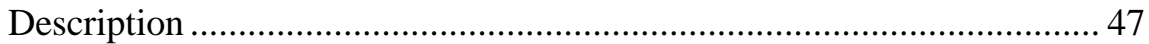

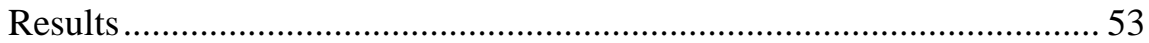

Plan G-1 - Removal of Both Eastern Gates, West Lock ............................... 53

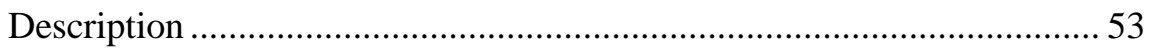

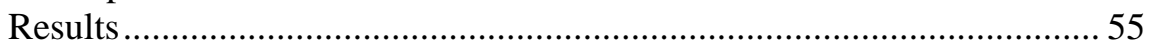

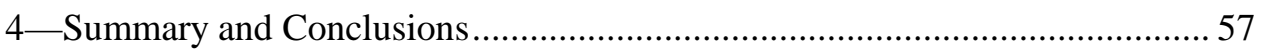

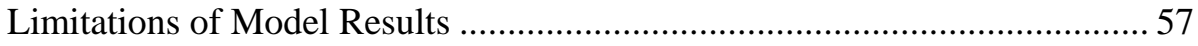

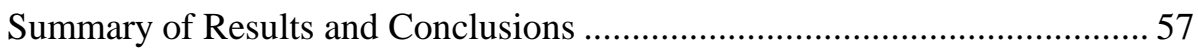

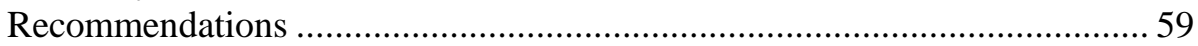

Plates 1-76

Appendix A: Colorado River Southwest Corner Stabilization ........................... A1

SF 298

\section{List of Figures}

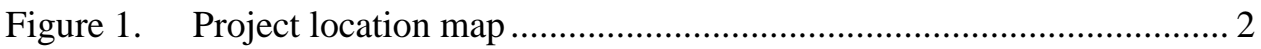

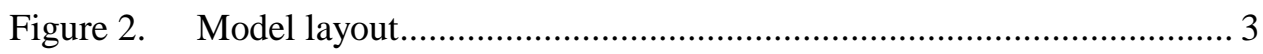

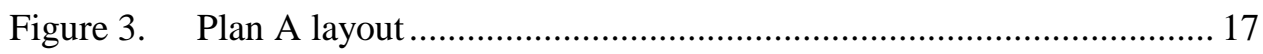

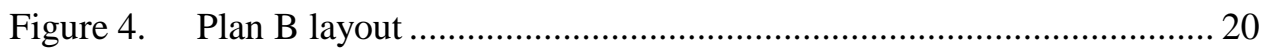

Figure 5. 6,000 cfs flow, no dredging, velocities at $8 \mathrm{ft}$ below WS ................ 22

Figure 6. 6,000 cfs flow, no dredging, velocities at $14 \mathrm{ft}$ below WS .............. 23

Figure 7. 6,000 cfs flow, dredged channel, velocities at $8 \mathrm{ft}$ below WS ......... 24

Figure 8. 6,000 cfs flow, dredged channel, velocities at $14 \mathrm{ft}$ below WS ....... 25

Figure 9. 6,000 cfs flow, dredged channel, velocities at $22 \mathrm{ft}$ below WS ........ 26

Figure 10. 10,000 cfs flow, no dredging, velocities at $8 \mathrm{ft}$ below WS .............. 27 
Figure 11. 10,000 cfs flow, no dredging, velocities at $14 \mathrm{ft}$ below WS

Figure 12. 10,000 cfs flow, dredged channel, velocities at $8 \mathrm{ft}$ below WS ....... 29

Figure 13. 10,000 cfs flow, dredged channel, velocities at $14 \mathrm{ft}$ below WS ..... 30

Figure 14. 10,000 cfs flow, dredged channel, velocities at $22 \mathrm{ft}$ below WS ...... 31

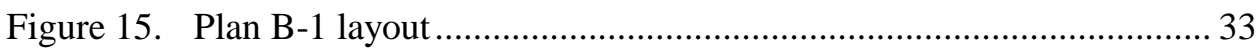

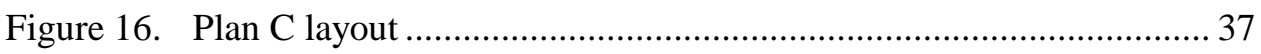

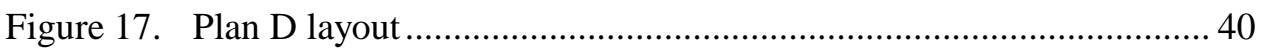

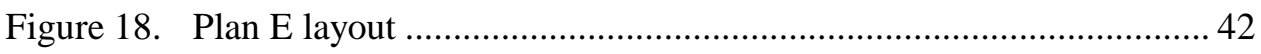

Figure 19. Flow east to west with bridge three tow lengths from confluence, tow moving east to west ................................................................. 45

Figure 20. Flow east to west with bridge two tow lengths from confluence, tow moving east to west 45

Figure 21. Flow east to west with bridge one tow length from confluence, tow moving east to west 46

Figure 22. Flow east to west with bridge three tow lengths from confluence, tow moving west to east 46

Figure 23. Flow east to west with bridge two tow lengths from confluence, tow moving west to east 48

Figure 24. Flow east to west with bridge one tow length from confluence, tow moving west to east

Figure 25. Flow west to east with bridge three tow lengths from confluence, tow moving east to west

Figure 26. Flow west to east with bridge two tow lengths from confluence, tow moving east to west

Figure 27. Flow west to east with bridge one tow length from confluence, tow moving east to west 50

Figure 28. Flow east to west with bridge three tow lengths from confluence, tow moving west to east 50

Figure 29. Flow east to west with bridge two tow lengths from confluence, tow moving west to east 
Figure 30. Flow east to west with bridge one tow length from confluence, tow moving west to east ................................................................. 51

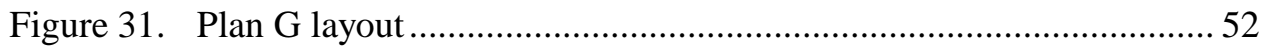

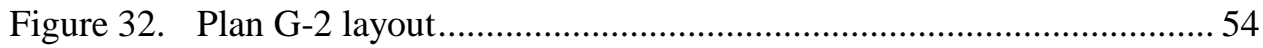




\section{Preface}

This study was conducted for the U.S. Army Engineer District, Galveston, in the Coastal and Hydraulics Laboratory (CHL) of the Engineer Research and Development Center, (ERDC), Vicksburg, MS, during the period April 1997 through August 1999.

During the course of the model study, representatives of the Galveston District and various navigation interests visited ERDC at different times to observe model operations and discuss experiment results. The Galveston District was kept informed of the progress of the study through monthly progress reports, periodic e-mail and telephone conversations, and briefings held during the course of the study.

The investigation was conducted under the general supervision of Dr. James R. Houston, former Director, CHL, Mr. Thomas W. Richardson, Acting Director, CHL, Mr. C. E. Chatham, Jr., Chief, Navigation and Harbors Division, and under the direct supervision of Dr. Sandra K. Knight, Chief, Navigation Branch. The principal investigator in charge of the model and preparation of the report was Mr. R.A. McCollum, assisted by Mr. B.T. Crawford, and Ms. Sally Harrison, all of the Navigation Branch.

At the time of publication of this report, Dr. James R.Houston was director of ERDC, and COL James S. Weller, EN, was Commander.

The contents of this report are not to be used for advertising, publication, or promotional purposes. Citation of trade names does not constitute an official endorsement or approval of the use of such commercial products. 


\section{Introduction}

\section{Location and Description of Prototype}

The Colorado River flows into the Gulf of Mexico, crossing the Gulf Intracoastal Waterway (GIWW) near Matagorda, TX (Figure 1). Two $365.8 \mathrm{~m}$ by $22.9 \mathrm{~m}(1,200 \mathrm{ft}$ by $75 \mathrm{ft})$ locks, one on each side of the Colorado River crossing of the GIWW, are provided to control flow into the GIWW and improve naviga-

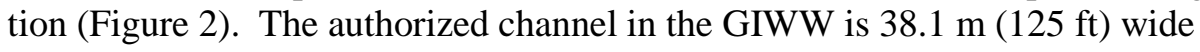
and is typically about $3.7 \mathrm{~m}$ ( $12 \mathrm{ft}$ ) deep. The original course of the Colorado River southward of the GIWW was south-southwesterly through the Matagorda Peninsula into the Gulf of Mexico. In the early 1990s, a diversion channel was dredged from the intersection of the Colorado River and GIWW southwesterly to the Matagorda Bay. The old channel was dammed just south of the intersection. A Bypass Channel was dredged between the GIWW, just east of the East Lock, and the old Colorado River channel southeastward of the Diversion Dam. [Until about 1990, flow from the Colorado passed southeastward into the East Matagorda Bay. At that time, a channel was dredged (Diversion Channel), starting at the Colorado River/GIWW intersection and going almost due south to the Matagorda Bay. The entrance to the old channel, immediately below the intersection was dammed. A short channel was dredged (Bypass Channel) between the GIWW, eastward of the East Lock and the old channel to East Matagorda Bay to provide access to East Matagorda Bay by commercial fishermen and pleasure craft. Prior to this, there was no tidal flow from East Matagorda Bay into the GIWW near the East Lock.] Diversion of flow into Matagorda Bay was performed to route the heavy sediment load into the bay to create shallow wetlands for environmental improvements of biologic productivity.

\section{Existing Conditions}

Navigation prior to and following construction of the Diversion and Bypass Channels is difficult when flows in the Colorado River are high, especially during the spring rainy season. Tows transiting the GIWW usually include one to four barges, varying in length from about $121.9 \mathrm{~m}$ (400 ft) up to $335.3 \mathrm{~m}$ $(1,100 \mathrm{ft})$ long, up to $16.5 \mathrm{~m}(54 \mathrm{ft})$ wide, and drafting up to $3.0 \mathrm{~m}(10 \mathrm{ft})$. An average tow is typically two or three barges, which depending on whether the

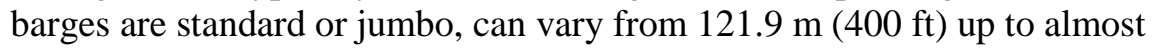
$121.9 \mathrm{~m}(900 \mathrm{ft})$. A typical push boat is about $21.3 \mathrm{~m}(70 \mathrm{ft})$. Restrictions are 


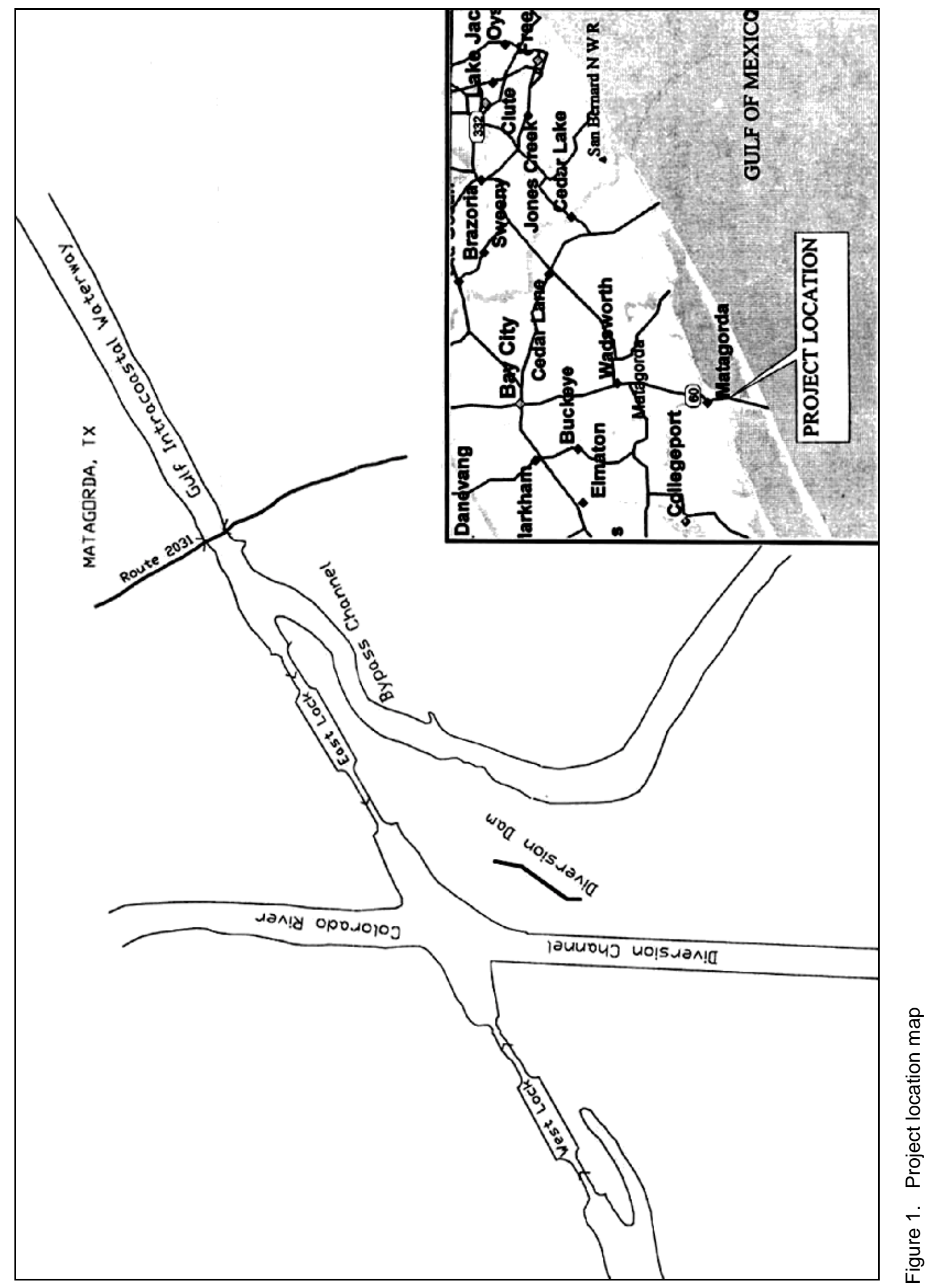




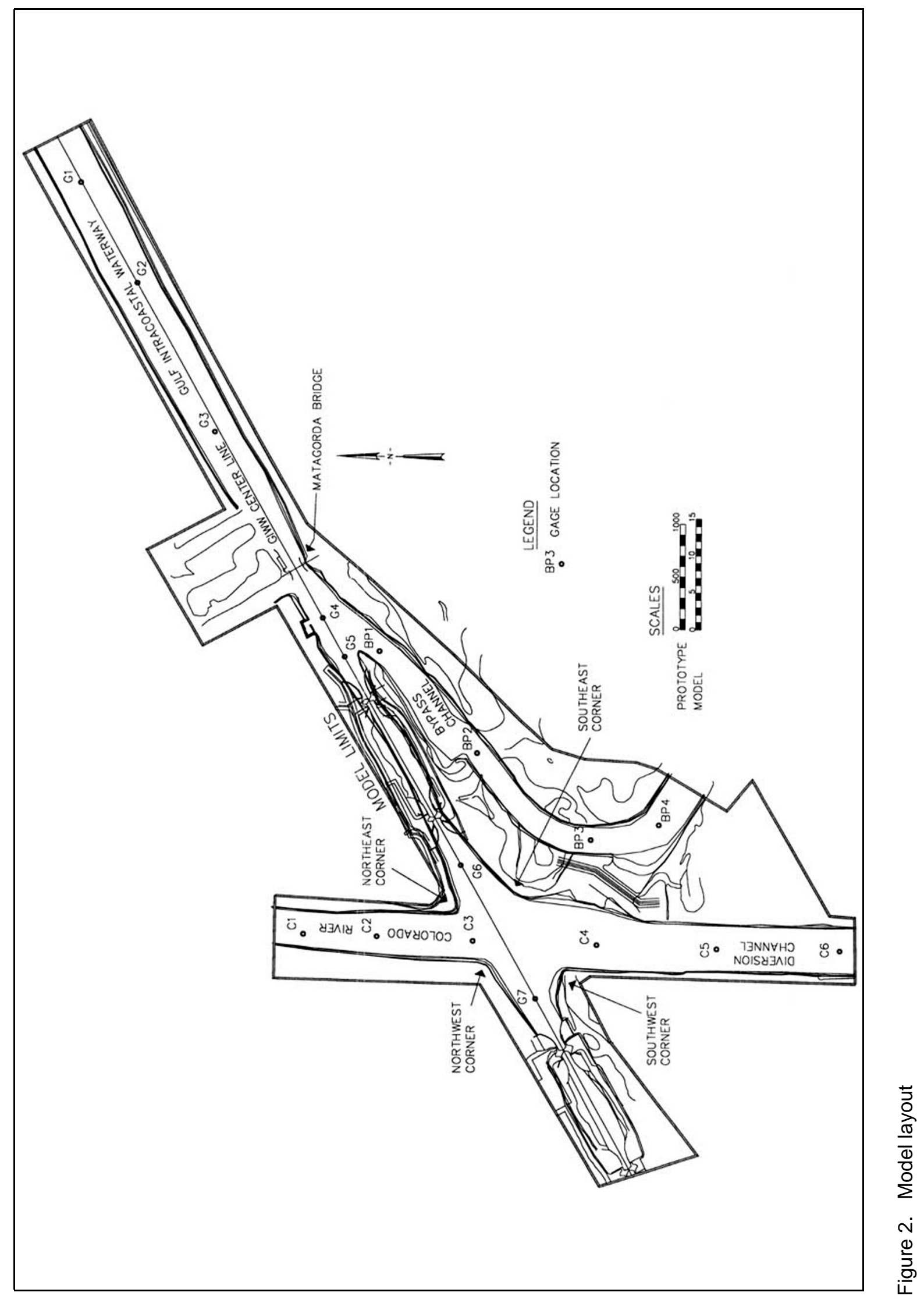


placed on the size of a tow that can cross the Colorado River when current speed in the river immediately upstream of the intersection is equal to or greater than $3.21 \mathrm{~km} / \mathrm{hr}(2.0 \mathrm{mph})$ or $0.9 \mathrm{~m} / \mathrm{sec}(3.0 \mathrm{fps})$. These restrictions require that only up to two empty barges or one loaded barge can cross, unless a helper boat is provided or a bow thruster is available. This then requires multibarge, loaded tows to be broken down into singles and "tripped" one at a time across the river.

Conditions worsened, according to tow pilots, shortly after the project to dredge the Diversion Channel, dam the entrance to the old channel, and dredge the Bypass Channel was completed. It was noted by tow pilots, the lockmaster, and the lock personnel that the southwest corner of the Colorado River/GIWW intersection started eroding almost immediately after the project was completed. After a period of one to two years, the tow pilots noted increasing difficulty in navigating across the intersection, especially when going east to west. The pilots also noted that navigation past the opening to the Bypass Channel, located midway between the east end of the East Lock and the floating pontoon highway bridge on Route 2031, was difficult when strong tidal currents were running in the Bypass Channel.

\section{Need for and Purpose of Model Study}

Navigation conditions at both the GIWW/Bypass Channel intersection and the Colorado River/GIWW intersection have changed considerably with the modifications made for diversion of flow into the Matagorda Bay. Long periods of high flow through the Colorado River that require "tripping" place a serious economic impact on operation of tows through the reach. A tow simulation study, ${ }^{1}$ along with a TABS-2 current model, ${ }^{2}$ was performed prior to completion of dredging of the Diversion Channel by the U.S. Army Engineer Research and Development Center (ERDC), Coastal and Hydraulics Laboratory (CHL). These studies did not indicate any significant increase in difficulty of navigation through the Colorado River/GIWW intersection but did note significant increase of difficulty in navigation past the Bypass Channel and suggested threshold velocities that would restrict traffic. In actual operation, as noted previously, tow pilots noted little change in difficulty in the Colorado/GIWW intersection immediately after the Diversion Channel was opened, but did notice changes shortly thereafter. At the request of the towing industry in July 1998, the U.S. Army Corps of Engineers dropped all restrictions on traffic past the Bypass Channel due to tidal flow, even though navigation during high tidal flow is still difficult.

At the request of the U.S. Army Engineer, Galveston, navigation studies were proposed. A physical model study was recommended due to the complexities of this reach. A 1:70 scale undistorted model using a radio controlled model towboat and barges would be used to:

\footnotetext{
1 Thevenot, Michelle M., and Daggett, Larry L., "Navigation Simulation Study, Mouth of the Colorado River, Matagorda, Texas," Technical Report CHL-97-6, March 1997.

2 Hauck, Larry M., "Hydrodynamics at Mouth of Colorado River, Texas, Project," Technical Report HL-92-11, September 1992.
} 
a. Examine alternatives for improvement of navigation conditions in the Colorado River/GIWW intersection.

$b$. Examine alternatives for improvement of navigation conditions between the Matagorda Bridge, Bypass Channel, and East Lock. 


\section{Physical Model}

\section{Description}

The model (Figure 2) reproduced about $0.8 \mathrm{~km}$ ( 0.5 miles) of the Colorado River immediately upstream of the intersection with the GIWW and approximately $1.2 \mathrm{~km}$ ( 0.75 miles) of the Diversion Channel south of the intersection. The model also reproduced both the East and West Locks, along with approximately $2.6 \mathrm{~km}$ (1.6 miles) of the GIWW eastward of the East Lock and the Bypass Channel from the junction with the GIWW for approximately $1.5 \mathrm{~km}$ (0.9 miles). The model was of the fixed-bed type with overbank areas and channels molded of sand cement mortar to sheet metal templates set to the proper grade. Portions of the model where changes in bank alignment and placement of new structures could be anticipated were molded in sand and overlaid with a thin layer of sand cement mortar to facilitate modifications necessary to determine navigation conditions associated with the various plans. The locks and guide walls were constructed of sheet metal and/or Plexiglas and set at the proper grade. The lock gates were simulated schematically with simple vertical sheet metal slide-type gates. The channel portion of the model was molded to conform to a hydrographic survey dated April 1997, and the overbanks were molded to a topographic survey dated August 1997.

\section{Scale Relations}

The model was built to an undistorted linear scale of 1:70, model to prototype. This scale allows accurate reproduction of velocities, eddies, and crosscurrents that would affect navigation. Other scale ratios resulting form the linear scale ratio are given in the following tabulation.

\begin{tabular}{|c|c|c|}
\hline Characteristic & Ratio $^{1}$ & $\begin{array}{l}\text { Scale Relations } \\
\text { Model:Prototype }\end{array}$ \\
\hline Length & 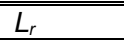 & $1: 70$ \\
\hline Area & $A_{r}=L_{r}^{2}$ & $1: 4,900$ \\
\hline Velocity & $\mathrm{V}_{\mathrm{r}}=\mathrm{L}_{\mathrm{r}}{ }^{1 / 2}$ & $1: 8.3667$ \\
\hline Time & $\mathrm{T}_{\mathrm{r}}=\mathrm{L}_{\mathrm{r}}^{1 / 2}$ & $1: 8.3667$ \\
\hline Discharge & $Q_{r}=L_{r}^{5 / 2}$ & $1: 40,996$ \\
\hline Roughness (Manning's n) & $\mathrm{N}_{\mathrm{r}}=\mathrm{L}_{\mathrm{r}}^{1 / 6}$ & $1: 2.03$ \\
\hline
\end{tabular}


Measurements of discharges, water-surface elevations, and current velocities can be transferred quantitatively from model to prototype using these scale relations.

\section{Appurtenances}

Water was supplied to the model by a 0.28 -cu $\mathrm{m} / \mathrm{s}-(10-\mathrm{cfs}-)$ pump operating in a recirculating system. The discharge was controlled and measured by a valve and a 0.15 by $0.075 \mathrm{~m}$ ( 6 by 3 in.) venturi meter. Water-surface elevations were measured by piezometer gages located in the model channel (Figure 2) and connected to a centrally located gage pit. For controlling the water-surface elevation in the Colorado River-Diversion Channel, a tailgate was provided at the end of the model. To enter flow or regulate water-surface in the GIWW/Bypass Channel, a flap-type tailgate and a 0.075 m- $(3$ in.) Van Leer weir were provided at both the eastern end of the GIWW and at the southern end of the Bypass Channel so flows could be reproduced for both the flood and ebb tide conditions.

\section{Model Validation}

The surface of the model was constructed of brushed cement mortar to provide a roughness (Manning's $n$ ) of about 0.0135 , which corresponds to a roughness in the prototype of about 0.030 . With the existing East and West Locks, Diversion Channel, and Bypass Channels in place, the model was operated to compare with prototype velocity measurements that were taken during April 1997. Measured model velocities compared favorably with prototype recorded at various positions in the Colorado/GIWW intersection, GIWW, and Bypass Channels. The results indicated that the model reproduced with a reasonable degree of accuracy conditions in the prototype at a discharge of approximately $934 \mathrm{cu} \mathrm{m} / \mathrm{s}(33,000 \mathrm{cfs})$. Velocities recorded in the prototype while a tow was passing or the lock gates were being operated were not used for comparisons with the model.

Time-lapse videotape recorders and cameras were installed from April through December 1997 at three sites at the project including the following:

a. East end of the East Lock, looking toward the Matagorda Bridge.

$b$. West end of the East Lock, looking across the intersection toward the West Lock.

c. East end of the West Lock, looking across the intersection toward the East Lock.

The cameras and videotape recorders were used to record the path and maneuvering required for tows to pass through the study area over an extended period of time and flow conditions. This information was then used to compare to model data taken from tows making similar passages entering and leaving the locks with various flow conditions. The comparison of the videotapes to the model operations of the tow indicate navigation conditions are reproduced with a reasonable degree of accuracy. 


\section{Model Experiments and Results}

\section{Experimental Procedures}

The primary objectives of the experiments were to a) study flow patterns, b) measure velocities, c) evaluate navigation conditions through the Matagorda Bridge, past the entrance to the Bypass Channel, and into the East Lock and the passage from the East Lock to the West Lock crossing the Colorado River, and d) evaluate modifications that might improve navigation conditions through these areas.

Flows from the Colorado River were reproduced by introducing the proper discharge and manipulating the tailgate at the end of the Diversion Channel until the required river stage elevation near the intersection of the Colorado River and GIWW was obtained. During base conditions (existing conditions), the Colorado River stages were controlled at Gage C3, near the intersection of the Colorado River and GIWW and for subsequent experiments, the water surface was controlled at Gage C6, near the end of the Diversion Channel to elevations obtained during the base experiments. For the GIWW and Bypass Channels, the river stages were controlled at Gage G5, near the eastern entrance to the East Lock and during subsequent experiments were controlled at either Gage G1 or B4, depending on the direction of flow being reproduced (Gage locations shown in Figure 2).

A selection of representative flows were used for experiments based on information furnished by the Galveston District and also from previous tow simulation modeling, as follows:

\begin{tabular}{||l|l|}
\hline Colorado River flow, cu m/s (cfs) & River Stage Near Intersection, m (ft) \\
\hline \hline $170(6,000)$ & $0.61(2.0)$ \\
\hline $283(10,000)$ & $0.76(2.5)$ \\
\hline $425(15,000)$ & $1.07(3.5)$ \\
\hline $566(20,000)$ & $1.22(4.0)$ \\
\hline $708(25,000)$ & $1.37(4.5)$ \\
\hline
\end{tabular}

Tidal flow through GIWW/Bypass, cu m/s (cfs) GIWW Stage Near East Lock, m (ft)

\begin{tabular}{|l|l}
\hline $62 \mathrm{~m}^{3} / \mathrm{s}(2,200 \mathrm{cfs})(1.61 \mathrm{~km} / \mathrm{hr}(1.0 \mathrm{mph})$ maximum velocity) & $0.91(3.0)$
\end{tabular}

\begin{tabular}{|l|l|l}
\hline $25 \mathrm{~m}^{3} / \mathrm{s}(4,400 \mathrm{cfs})(2.82 \mathrm{~km} / \mathrm{hr}(1.75 \mathrm{mph})$ maximum velocity) & $0.91(3.0)$
\end{tabular}

\begin{tabular}{|l|l|l}
\hline $159 \mathrm{~m}^{3} / \mathrm{s}(5,600 \mathrm{cfs})(4.03 \mathrm{~km} / \mathrm{hr}(2.5 \mathrm{mph})$ maximum velocity) & $0.91(3.0)$
\end{tabular}

Note: Velocity measured in entrance to Bypass Channel. 
Flow conditions for the GIWW/Bypass Channels were established by obtaining the appropriate velocity just inside Bypass Channel, near the confluence with the GIWW, at the same position where a realtime velocity gaging station is located. At the time this study was initiated, $3.22 \mathrm{~km} / \mathrm{hr}$ $(2.0 \mathrm{mph})$ or greater currents, as measured at the prototype gaging station, would require tripping. These restrictions were dropped at the request of the towing industry in July 1997. The velocities of $1.61,2.82,4.03 \mathrm{~km} / \mathrm{hr}(1.0,1.75$, and $2.5 \mathrm{mph}$ ) were previously used as the velocity conditions for the tow simulation study. The lock operator gives information to passing tows on the current velocity and direction of flow in the Bypass Channel. The flow conditions used for the GIWW/Bypass Channel will be identified in this report by the current speed and direction rather than by discharge.

Current directions were determined by tracking the path of lighted floats, weighted to draft $3.0 \mathrm{~m}(10 \mathrm{ft})$, with respect to ranges established for that purpose with the video camera tracking system mounted over the model. Velocities were computed by a desktop computer, which calculates velocity using the time required by floats to pass over a measured distance. This method provided detailed information on the currents that would affect tows moving through the reach. In the interest of clarity, in the case of plots of currents in turbulent areas or where eddies or crosscurrents existed, only the main trends are shown.

When needed, point velocities were taken with an accoustic doppler velocity meter. The meter sends out an accoustic signal obliquely to the probe which is reflected by minute dirt particles or a "seeding" material in the water back to the probe sensors. The shift in the reflected accoustic signal can then be used to determine two-dimensional velocities. The resultants of the two-dimensional ( $x$ and $y$ ) velocities yields the magnitude and direction of the velocities. The probe can be used to record velocities to within $3 \mathrm{~mm}$ of the model bed and within $5 \mathrm{~mm}$ of the water surface.

A radio-controlled towboat and barges were used to evaluate and demonstrate the affects of currents on navigation. The towboat was equipped with twin screws, Kort nozzles, forward and reverse rudders, and powered by two small electric motors operating from batteries in the tow. The speed of each engine and direction of the rudders were remotely controlled, and the towboat could be operated in forward and reverse at speeds comparable to those that could be expected to be used by typical tows in the study reach. The tow used in the study represented a makeup of three $89.9-\mathrm{m}$ - (295-ft-) long by $16.5-\mathrm{m}$ - (54-ft-) wide jumbo barges, with a $21.3-\mathrm{m}(70-\mathrm{ft})$ pusher. This provided an overall size tow of 291.1-m (955 ft) long by 16.5-m (54-ft) wide loaded to a draft of $3.0 \mathrm{~m}(10 \mathrm{ft})$. The model towboat provided an accurate representation of the maneuvering characteristics of prototype towboats based on comparisons with the time-lapse video recorded in the prototype and discussions with pilots. This was later confirmed by pilots when they viewed the model and operated the model towboat. The towboat was calibrated to the speed of a comparable size prototype towboat moving in slack water and was powered to be operated at 1.61 to $3.22 \mathrm{~km} / \mathrm{hr}$ (1 to $2 \mathrm{mph}$ ) above the speed of the currents to maintain rudder control but not overpower the currents. A model tow does not have a specific horsepower rating but is controlled to provide only enough power to keep the tow 
moving at a speed sufficient to maintain rudder control. The video tracking system was used to track the model tow and provide vessel track plots for evaluation of navigation conditions.

\section{Base Experiments (Existing Conditions)}

\section{Description}

Base experiments were conducted with the model reproducing existing conditions as shown in Figure 2. The purposes of the experiments were to verify that the model was reproducing known prototype conditions and provide information and baseline data that could be used to evaluate the effect of the proposed modification on water-surface elevations, current direction and velocities, and navigation conditions. The principal features reproduced in the model, as shown in Figure 2, include the following:

a. The East and West Locks, each with a clear chamber dimension of $22.9 \mathrm{~m}$ $(75 \mathrm{ft})$ wide by $365.8 \mathrm{~m}(1,200 \mathrm{ft})$ long with an approximately $304 \mathrm{~m}$ $(1,000 \mathrm{ft})$ timber piling guide wall between the miter gates of each lock. The sill elevation of the locks is -15 mean low tide (mlt) ${ }^{1}$ with the top of the miter gate walls at 16 mlt.

$b$. The Matagorda Bridge, which consists of a series of pilings that support the approaches to the floating, retractable pontoon bridge, protected by fenders with a clearance between the fenders of $41.1 \mathrm{~m}(135 \mathrm{ft})$, on the north and south banks of the GIWW, approximately $426.7 \mathrm{~m}(1,400 \mathrm{ft})$ eastward of the east miter gates of the East Lock.

c. The Diversion Dam, which closes the old Colorado River channel to flow from the Colorado, with an earthen dam with a crest elevation of 16 mlt.

Most tow runs were made assuming the tow had been locked through with no flow through the lock or open lock condition. Some evaluations were made with flow passing through the East and West Locks to determine how the flow through the locks would influence navigation conditions as compared with "no flow" conditions.

Tow traffic that crosses the Colorado River/GIWW intersection is now restricted to "tripping" when velocities in the Colorado River are $3.2 \mathrm{~km} / \mathrm{hr}$ $(2.0 \mathrm{mph})[0.91 \mathrm{~m} / \mathrm{s}$ ( $3.0 \mathrm{fps})]$ or greater. The $283 \mathrm{cu} \mathrm{m} / \mathrm{s}(10,000 \mathrm{cfs})$ flow condition reproduced in the model replicates this critical condition. Velocities using the $425 \mathrm{cu} \mathrm{m} / \mathrm{s}(15,000 \mathrm{cfs})$ flow condition were up to $1.22 \mathrm{~m} / \mathrm{s}(4.0 \mathrm{fps})$. It was determined early in the study that improvements to navigation in the crossing with velocities this high and greater was unlikely. Examination of reported accidents at the intersection by Galveston District personnel also determined that most accidents occurred when flow from the Colorado River was

${ }^{1}$ All elevations (el) cited herein are in feet referenced to the National Geodetic Vertical Datum (NGVD) (To convert feet to meters, multiply number of feet by 0.3048). 
from 170 to $283 \mathrm{cu} \mathrm{m} / \mathrm{s}$ (6000 to $10,000 \mathrm{cfs}$ ) when velocities in the crossing are less the $0.91 \mathrm{~m} / \mathrm{s}(3.0 \mathrm{fps})$ threshold. Evaluation of navigation conditions, using the model tow, only used two of the discharges, 170 and $283 \mathrm{cu} \mathrm{ms}(6,000$ and $10,000 \mathrm{cfs})$.

For evaluation of the GIWW/Bypass Channel, current directions and velocities were taken for the three flow conditions established, 1.61, 2.82, and $4.03 \mathrm{~km} / \mathrm{hr}(1.0,1.75$, and $2.5 \mathrm{mph})$. During preliminary evaluations, it was determined that navigation past the Bypass Channel was not extremely difficult with the 1.61 and $2.82 \mathrm{~km} / \mathrm{hr}(1.0$ and $1.75 \mathrm{mph})$ flow conditions. To expedite the study, it was further decided that evaluation of navigation conditions for the base condition and any subsequent improvement plans with the use of the model towboat should be reserved for the most difficult event, the $4.03 \mathrm{~km} / \mathrm{hr}(2.5 \mathrm{mph})$ current with both the ebb and flood tide conditions.

Minor changes in the water-surface elevations [normally less than $0.03 \mathrm{~m}$ $(0.1 \mathrm{ft})$, prototype] brought about by the plan proposals were not considered when evaluating the plans. Water-surface elevation was not considered as part of the design criteria in development or evaluation of any plan condition. Watersurface elevations as recorded for the existing conditions are presented in Table 1, but will not be discussed in the results.

\begin{tabular}{|c|c|c|c|c|c|c|c|c|c|c|c|}
\hline Gage No. & $\begin{array}{l}170 \mathrm{cu} \mathrm{m} / \mathrm{s} \\
(6,000 \mathrm{cfs})\end{array}$ & $\begin{array}{l}283 \mathrm{cu} \mathrm{m} / \mathrm{s} \\
(10,000 \mathrm{cfs})\end{array}$ & $\begin{array}{l}425 \mathrm{cu} \mathrm{m} / \mathrm{s} \\
(15,000 \mathrm{cfs})\end{array}$ & $\begin{array}{l}566 \mathrm{cu} \mathrm{m} / \mathrm{s} \\
(20,000 \mathrm{cfs})\end{array}$ & $\begin{array}{l}708 \mathrm{cu} \mathrm{m} / \mathrm{s} \\
(25,000 \mathrm{cfs})\end{array}$ & $\begin{array}{l}\text { Ebb } \\
1.61 \\
\mathrm{~km} / \mathrm{hr} \\
(1.0 \mathrm{mph})\end{array}$ & \begin{tabular}{|l} 
Ebb \\
$2.83 \mathrm{~km} / \mathrm{hr}$ \\
$(1.75 \mathrm{mph})$
\end{tabular} & \begin{tabular}{|l} 
Ebb \\
$4.03 \mathrm{~km} / \mathrm{hr}$ \\
$(2.75 \mathrm{mph})$
\end{tabular} & $\begin{array}{l}\text { Flood } \\
1.61 \\
\mathrm{~km} / \mathrm{hr} \\
(1.0 \mathrm{mph})\end{array}$ & $\begin{array}{l}\text { Flood } \\
2.83 \mathrm{~km} / \mathrm{hr} \\
(1.75 \mathrm{mph})\end{array}$ & $\begin{array}{l}\text { Flood } \\
4.03 \mathrm{~km} / \mathrm{hr} \\
(2.75 \mathrm{mph})\end{array}$ \\
\hline C1 & 2.1 & 2.6 & 3.4 & 74.2 & 74.9 & T* & T* & T* & $\overline{T *}$ & * & "* \\
\hline$\overline{\mathrm{C} 2}$ & 2.1 & 2.6 & 3.4 & 4.2 & 4.9 & * & * & * & * & * & * \\
\hline \begin{tabular}{|l|}
$\mathrm{C} 3$ \\
\end{tabular} & 2.0 & 2.5 & 3.4 & 4.1 & 4.9 & * & * & * & * & * & * \\
\hline C4 & 2.0 & 2.5 & 3.3 & 4.0 & 4.8 & * & * & * & * & * & * \\
\hline C5 & 1.9 & 2.4 & 3.1 & 3.8 & 4.4 & * & * & * & * & * & * \\
\hline C6 & 1.9 & 2.4 & 3.0 & 3.7 & 4.3 & * & * & * & * & * & * \\
\hline G1 & * & * & * & * & * & 3.0 & 3.1 & 3.2 & 2.9 & 2.9 & 2.8 \\
\hline G2 & * & * & * & * & * & 3.0 & 3.1 & 3.2 & 3.0 & 2.9 & 2.9 \\
\hline G3 & * & * & * & * & * & 3.0 & 3.1 & 3.1 & 3.0 & 3.0 & 2.9 \\
\hline G4 & * & * & * & * & * & 3.0 & 3.0 & 3.0 & 3.0 & 3.0 & 3.0 \\
\hline G5 & * & * & * & * & * & 3.0 & 2.9 & 3.0 & 3.0 & 3.0 & 3.0 \\
\hline $\begin{array}{l}\text { G7 } \\
\text { (East Lock } \\
\text { approach) }\end{array}$ & 2.0 & 2.5 & 3.3 & 4.1 & 4.9 & * & * & $*$ & * & * & * \\
\hline $\begin{array}{l}\text { G8 } \\
\text { (West Lock } \\
\text { approach) }\end{array}$ & 2.0 & 2.5 & 3.3 & 4.1 & 4.9 & * & * & * & * & * & * \\
\hline BP1 & * & * & * & * & * & 2.9 & 2.9 & 2.9 & 3.0 & 3.0 & 3.1 \\
\hline BP2 & * & * & * & * & * & 2.8 & 2.8 & 2.8 & 3.0 & 3.0 & 3.1 \\
\hline BP3 & * & * & * & * & * & 2.8 & 2.8 & 2.7 & 3.0 & 3.0 & 3.2 \\
\hline BP4 & * & * & * & * & * & 2.7 & 2.7 & 2.6 & 3.1 & 3.1 & 3.2 \\
\hline
\end{tabular}

\section{Results}

\section{Current directions and velocities, GIWW/Bypass Channel .}

Ebb tide. The $1.61 \mathrm{~km} / \mathrm{hr}(1.0 \mathrm{mph})$ condition (Plate 1) indicates velocities of up to $0.40 \mathrm{~m} / \mathrm{s}(1.3 \mathrm{fps})$ near the entrance to the Bypass Channel, $0.37 \mathrm{~m} / \mathrm{s}$ 
(1.2 fps) through the bridge, and generally $0.31 \mathrm{~m} / \mathrm{s}(1.0 \mathrm{fps})$ or less eastward of the bridge. Currents are generally parallel to the bank lines before being impinged by the bridge. The $2.82 \mathrm{~km} / \mathrm{hr}(1.75 \mathrm{mph})$ condition (Plate 2) indicates velocities of near $0.73 \mathrm{~m} / \mathrm{s}(2.4 \mathrm{fps})$ near the entrance to the Bypass Channel, $0.76 \mathrm{~m} / \mathrm{s}$ (2.5 fps) through the bridge, generally about $0.61 \mathrm{~m} / \mathrm{s}(2.0 \mathrm{fps})$ or less eastward of the bridge, and a slow clockwise eddy formed in the approach to the East Lock. The $4.03 \mathrm{~km} / \mathrm{hr}$ (2.5 mph) condition (Plate 3) indicates velocities near the entrance to the Bypass Channel of up to $1.13 \mathrm{~m} / \mathrm{s}(3.7 \mathrm{fps}), 1.10 \mathrm{~m} / \mathrm{s}(3.6 \mathrm{fps})$ through the bridge, and generally $0.91 \mathrm{~m} / \mathrm{s}(3.0 \mathrm{fps})$ or less eastward of the bridge. The clockwise eddy in the lock approach increased velocity slightly as compared with the $2.82 \mathrm{~km} / \mathrm{hr}(1.75 \mathrm{mph})$ condition. The currents at the entrance to the Bypass Channel appear to concentrate along the right descending bank line of the Bypass Channel as they enter the channel for the $4.03 \mathrm{~km} / \mathrm{hr}(2.5 \mathrm{mph})$ flow.

Flood tide. The $1.16 \mathrm{~km} / \mathrm{hr}(1.0 \mathrm{mph})$ condition (Plate 4$)$ indicates velocities of $0.43 \mathrm{~m} / \mathrm{s}(1.4 \mathrm{fps})$ near the entrance of the GIWW/Bypass, $0.46 \mathrm{~m} / \mathrm{s}(1.5 \mathrm{fps})$ through the bridge, and generally from 0.31 to $0.37 \mathrm{~m} / \mathrm{s}$ (1.0 to $1.2 \mathrm{fps}$ ) eastward of the bridge. Currents coming eastward from the Bypass Channel tend to stay parallel to the southern bank line of the Bypass Channel, turning to parallel the GIWW as they come through the bridge. The $2.22 \mathrm{~km} / \mathrm{hr}(1.75 \mathrm{mph})$ condition (Plate 5) indicates currents of up to $0.76 \mathrm{~m} / \mathrm{s}$ (2.5 fps) near the confluence, $0.76 \mathrm{~m} / \mathrm{s}(2.5 \mathrm{fps})$ through the bridge, and generally from $0.67 \mathrm{~m} / \mathrm{s}(2.2 \mathrm{fps})$ near the bridge to $0.49 \mathrm{~m} / \mathrm{s}(1.6 \mathrm{fps})$ at the eastern model limits of the GIWW. A small counterclockwise eddy has formed just riverward of the Corps boathouse. The $4.03 \mathrm{~km} / \mathrm{hr}(2.5 \mathrm{mph})$ condition (Plate 6$)$ indicates velocities of up to $1.25 \mathrm{~m} / \mathrm{s}(4.1 \mathrm{fps})$ near the confluence, $1.13 \mathrm{~m} / \mathrm{s}(3.7 \mathrm{fps})$ through the bridge, and gradually decreasing currents from about $0.98 \mathrm{~m} / \mathrm{s}(3.2 \mathrm{fps})$ about $305 \mathrm{~m}$ $(1,000 \mathrm{ft})$ eastward of the bridge to $0.70 \mathrm{~m} / \mathrm{s}(2.3 \mathrm{fps})$ near the eastern model extents of the GIWW. A large counterclockwise eddy has formed from the Corps boathouse, approximately midway between the bridge and the East Lock, to almost the wing walls of the approach to the East Lock.

Current directions and velocities, Colorado/Diversion Channel. For the $170 \mathrm{cu} \mathrm{m} / \mathrm{s}(6,000 \mathrm{cfs})$ condition (Plate 7), velocities were up to $0.56 \mathrm{~m} / \mathrm{s}$ (1.9 fps) along the left descending bank line of the Colorado immediately upstream of the crossing, approximately 0.46 to $0.49 \mathrm{~m} / \mathrm{s}$ ( 1.5 to $1.6 \mathrm{fps})$ in the center of the crossing, and 0.49 to $0.55 \mathrm{~m} / \mathrm{s}$ (1.6 to $1.8 \mathrm{fps}$ ) near the right descending bank of the Diversion Channel immediately downstream of the crossing. A small counterclockwise eddy was noted near the southeast and southwest corners of the intersection.

With the $283 \mathrm{cu} \mathrm{m} / \mathrm{s}(10,000 \mathrm{cfs})$ flow (Plate 8), velocities were up to $0.88 \mathrm{~m} / \mathrm{s}(2.9 \mathrm{fps})$ along the left bank line of the Colorado, up to $0.73 \mathrm{~m} / \mathrm{s}$ $(2.4 \mathrm{fps})$ in the center of the intersection, and up to $0.77 \mathrm{~m} / \mathrm{s}(2.6 \mathrm{fps})$ near the center of the channel and slightly toward the right bank of the Diversion Channel just downstream of the intersection. Two distinct eddies formed in the East Lock approach. The large, faster one moves counterclockwise along the edge of the current flow between the northeast and southeast corners, and the small, clockwise eddy, driven by the large eddy, is formed about midway between the East 
Lock and the intersection. A large clockwise eddy has formed in the West Lock approach and covers about half of the approach starting from the edge of the downstream current flow to approximately midway between the intersection and the West Lock.

The $425 \mathrm{cu} \mathrm{m} / \mathrm{s}(15,000 \mathrm{cfs})$ condition (Plate 9) has currents of up to $1.22 \mathrm{~m} / \mathrm{s}$ (4.0 fps) along the left bank of the Colorado, up to $1.07 \mathrm{~m} / \mathrm{s}$ (3.5 fps) near the center of the intersection, and up to $1.10 \mathrm{~m} / \mathrm{s}(3.6 \mathrm{fps})$ well downstream into the Diversion Channel. A large, counterclockwise eddy has formed between the edge of the downstream currents and the approach to the East Lock, with a smaller clockwise eddy formed eastward toward the East Lock. A large, slow clockwise eddy has formed in the approach to the West Lock.

For the $566 \mathrm{cu} \mathrm{m} / \mathrm{s}(20,000 \mathrm{cfs})$ flow condition (Plate 10), velocities are up to $1.59 \mathrm{~m} / \mathrm{s}$ (5.2 fps) along the left bank of the Colorado, $1.25 \mathrm{~m} / \mathrm{s}(4.1 \mathrm{fps})$ in the center of the intersection, and in excess of $1.22 \mathrm{~m} / \mathrm{s}$ ( $4.0 \mathrm{fps})$ entering the Diversion Channel. The counterclockwise eddy in the east approach has remained about the same size as with the $425 \mathrm{cu} \mathrm{m} / \mathrm{s}(15,000 \mathrm{cfs})$ condition, but is significantly stronger, as is the eddy in the west approach.

The $708 \mathrm{cu} \mathrm{m} / \mathrm{s}(25,000 \mathrm{cfs})$ condition (Plate 11) has velocities up to $1.86 \mathrm{~m} / \mathrm{s}(6.1 \mathrm{fps})$ along the left bank of the Colorado, $1.52 \mathrm{~m} / \mathrm{s}(5.0 \mathrm{fps})$ in the center of the intersection, and in excess of $1.83 \mathrm{~m} / \mathrm{s}(6.0 \mathrm{fps})$ in the Diversion Channel. Eddies in the east and west lock approaches have somewhat enlarged in size as compared with the $566 \mathrm{cu} \mathrm{m} / \mathrm{s}(20,000 \mathrm{cfs})$ flow condition.

Navigation conditions, GIWW/Bypass Channel. As stated previously, no seriously adverse navigation conditions were noted with the 1.67 and $2.82 \mathrm{~km} / \mathrm{hr}$ (1.0 and $1.75 \mathrm{mph}$ ) flow conditions. With the ebb tide, $4.03 \mathrm{~km} / \mathrm{hr}(2.5 \mathrm{mph})$ condition, and the tow moving westward toward the lock (Plate 12), the strong currents require a relatively high tow speed to maintain steerage. If the tow is positioned near the center of the span between the bridge fenders, it is extremely difficult to keep the tow from being set down into the entrance of the Bypass Channel. The most successful approaches were made by keeping the tow as far northward as possible while coming through the bridge. There is no opportunity to slow the tow much as it comes into the eastern gate of the East Lock without becoming more susceptible to the current running out the Bypass Channel.

The $4.03 \mathrm{~km} / \mathrm{hr}(2.5 \mathrm{mph})$ condition with ebb tide and the tow moving eastward from the East Lock (Plate 13), the best approach was made by keeping the tow as far northward as possible to give maneuvering room when the tow starts setting southward. The stern of the tow must be allowed to come southward to control the set on the head of the tow, then as head of the tow gets between the fenders, the stern can be steered northward. If the tow is steered near midchannel of the GIWW, it is very difficult to keep from striking the southern bridge fender.

The $4.03 \mathrm{~km} / \mathrm{hr}(2.5 \mathrm{mph})$ condition with flood tide and the tow moving westward toward the lock (Plate 14) is not nearly as difficult as with the ebb tide condition. The tow can be driven slower into current and maintain steerage. The 
flow through the bridge slows the tow even more. The best approach appeared to be slightly south of the center line of the GIWW while approaching the bridge. The current sets the tow northward, but is not extremely difficult to manage. As the tow passes through the bridge, the current effect is markedly reduced and entrance into the East Lock is not difficult.

With the $4.03 \mathrm{~km} / \mathrm{hr}(2.5 \mathrm{mph})$ condition, flood tide, and the tow travelling from west to east (Plate 15), the best approach appeared to be turning the tow slightly into the current so that the northward set on the head of the tow as it approached the bridge was easier to control. As the head of the tow passed through the bridge fenders, the stern could be steered southward into the current. This brought the tow close to the northern bridge fenders. It was difficult to turn the head of the tow further southward before reaching the bridge since it was already being influenced by the currents coming from the Bypass Channel before the stern of the tow cleared the lock and became more maneuverable.

Navigation conditions, Colorado/Diversion Channel. With the $170 \mathrm{cu} \mathrm{m} / \mathrm{s}$ $(6,000 \mathrm{cfs})$ flow condition and tows moving east to west (Plate 16), the tow coming out of the East Lock is turned slightly into the current. As the tow gets about midlength into the intersection, the current starts setting the head of the tow

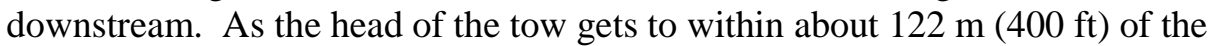
miter gate of the West Lock, the set on the head of the tow is gone and the set on the stern of the tow is controlled by steering up into the current. At this point, speed can be reduced and the head of the tow brought into the West Lock without great difficulty.

With the $170 \mathrm{cu} \mathrm{m} / \mathrm{s}(6,000 \mathrm{cfs})$ flow condition and the tows moving west to east (Plate 17), the head of the tow is maneuvered slightly north of the GIWW center line as the stern of the tow passes out of the West Lock. The head of the tow starts setting downstream just as the stern clears the lock and becomes fully maneuverable. As the head of the tow reaches a point due south of the northeast corner, the set on the head of the tow is diminished. As the stern comes out into the intersection, the set is again controllable by steering into the current. The stern of the tow gets out of the current set as the head comes to within about $122 \mathrm{~m}$ (400 ft) of the East Lock miter gate, slightly eastward of the East Lock wing walls. From this point, getting into alignment to get into the lock is not difficult.

With the $283 \mathrm{cu} \mathrm{m} / \mathrm{s}(10,000 \mathrm{cfs})$ flow condition and tow traffic moving from east to west (Plate 18), the tow is brought out somewhat slowly to allow the counterclockwise eddy that works in the approach to rotate the head of the tow northward until the tow clears the lock chamber. As the tow clears the lock, the engines are set for the maximum permissible power. This power setting was determined during preliminary evaluations by using specific throttle settings and comparing crossing times between the East and West Locks in the model to crossings recorded on the video monitoring systems installed on the locks. The throttle settings were adjusted until the passage time between the East and West Locks corresponded to typical crossings in the prototype, then this throttle setting was used as the maximum amount of power available. As the tow clears the lock, the stern is steered southward to push the head of the tow further north and 
obtain a larger angle into the current before the tow gets out into the intersection. As approximately one-third of the tow gets out into the intersection, the current set starts become noticeable. The stern of the tow is then steered hard right to resist the set on the head. As the tow gets about two-thirds of it's length into the intersection, the entire tow moves laterally downstream. As the head of the tow passes westward of the northwest corner, the set on the head of the tow is greatly diminished. At this point, the rudder on the towboat is reversed to hard left to hold the stern up against the current set. This hard left rudder must be maintained, along with full power to keep the tow from being set down on the southwest corner. If the head of the tow is slightly too far north of the GIWW center line when it stops setting, it is very difficult to keep from hitting the north wing wall on the West Lock. This is because the tow does not get completely out of the current until the head of the tow is within the 22.9-m (75-ft) width section of the wing wall and the stern of the tow cannot be steered northward into the currents. If the head of the tow is slightly too far south of the GIWW center line when the set stops, it becomes difficult to keep from grounding on the southwest corner or striking the south wing wall of the West Lock. Hitting the south wing wall happens if the stern is not allowed to set southward to turn the head of the tow northward and grounding on the southwest point happens if the stern of the tow is set too far southward.

For the $283 \mathrm{cu} \mathrm{m} / \mathrm{s}(10,000 \mathrm{cfs})$ flow condition and tows moving west to east (Plate 19), it is difficult to position the tow to steer into the current. The tow has limited steering maneuverability while still in the lock and the head of the tow is almost out into the current before the stern clears the lock and wing walls. The head of the tow starts setting southward as it passes the northwest corner. The towboat must be steered hard left to help limit the amount of set on the head of the tow. The tow starts setting laterally as approximately the first half of it gets into the intersection. The tow sets southward until the head of the tow passes eastward of the northeast corner and the set on the head is diminished. The stern of the tow is then steered hard right to keep the stern from setting further south. The stern of the tow will not move northward against the current until the stern gets out of the currents, which is when the head of the tow is about 91.4 to 121.9 $\mathrm{m}$ (300 to $400 \mathrm{ft}$ ) from the miter gate of the East Lock. Once the stern is clear of the currents, the tow can be slowed and brought into alignment to enter the East Lock with moderate difficulty. There is some difficulty in keeping the tow from striking the north wing wall on the East Lock if the head of the tow is slightly too far north of the GIWW center line when the stern comes out of the currents in the intersection or from grounding on the southeast corner if the tow is allowed to set too far south of the GIWW center line. The difficulty of the transit from east to west is significantly greater than that of transit from west to east with this flow condition.

\section{Plan A - L-Head Dike}

\section{Description}

After completion of base condition evaluations, the model was operated to evaluate placement of structures in the Colorado River, immediately upstream of 
the intersection or somewhere in the intersection, that would a) divert flow from the right descending bank line before it entered the intersection, b) reduce velocities of currents in the intersection, and/or c) increase the size of the eddy that normally forms in the approach to the West Lock. These were attempts to provide a larger zone of lower velocity or near slack currents in the approach to the West Lock so that the three-barge tow would have the stern of the tow out of the currents or would have less of the tow in the currents as the head of the tow entered between the wing walls of the West Lock. Several iterations of various placements of training structures were considered. The structure that appeared to provide the most benefit was an L-head type dike, placed on the right descending bank upstream of the intersection (Figure 3). The spur portion of the dike was $365.8 \mathrm{~m}(1,200 \mathrm{ft})$ upstream of the GIWW center line, as measured parallel to the right descending bank line, perpendicular to the bank line, with a length of $18.3 \mathrm{~m}(60 \mathrm{ft})$. The trailing leg of the dike was approximately $233.1 \mathrm{~m}(765 \mathrm{ft})$ long and slightly curved toward the left descending bank line. The crest elevation of the dike was $0.76 \mathrm{~m}(2.5 \mathrm{ft}) \mathrm{mlt}$. This elevation was used to maximize the effect of the dike at the critical flow condition of $283 \mathrm{cu} \mathrm{m} / \mathrm{s}$ $(10,000 \mathrm{cfs})$ and to minimize the effects of the dike as the discharge and river stage got higher.

\section{Results}

Current directions and velocities. For the $170 \mathrm{cu} \mathrm{m} / \mathrm{s}$ (6,000 cfs) flow condition (Plate 20), the currents along the left descending bank line, adjacent to the dike were up to $0.88 \mathrm{~m} / \mathrm{s}$ ( $2.9 \mathrm{fps})$. The dike concentrated flow toward the left descending side of the intersection and had a maximum velocity of $0.73 \mathrm{~m} / \mathrm{s}$ ( $2.4 \mathrm{fps})$ near the center of the intersection. Currents entering the Diversion Channel were generally about $0.61 \mathrm{~m} / \mathrm{s}(2.0 \mathrm{fps})$ or less. The eddy in the East Lock approach was much stronger and better defined than with the base conditions. The eddy in the West Lock approach extends further eastward toward the intersection than with the base conditions.

For the $283 \mathrm{cu} \mathrm{m} / \mathrm{s}(10,000 \mathrm{cfs})$ flow condition (Plate 21), currents along the left descending bank adjacent to the dike were up to $1.28 \mathrm{~m} / \mathrm{s}$ ( $4.2 \mathrm{fps})$. The flow is again concentrated along the left descending side of the intersection with the maximum velocity near the center of the intersection of $1.04 \mathrm{~m} / \mathrm{s}(3.4 \mathrm{fps})$. Currents entering the Diversion Channel were generally about $0.82 \mathrm{~m} / \mathrm{s}(2.7 \mathrm{fps})$. The eddy in the East Lock approach is very similar to that with the base conditions. The eddy in the West Lock approach is greatly enlongated along the center line of the GIWW and extends well eastward into the intersection.

Navigation conditions. Tows moving east to west with the $170 \mathrm{cu} \mathrm{m} / \mathrm{s}$ $(6,000 \mathrm{cfs})$ flow condition (Plate 22) experienced a greater set as compared with the base conditions as the tow entered the intersection. This greater set was offset by the increased size of the eddy in the West Lock approach. The stern of the tow moved into the near slack water as the head came within about $61.0 \mathrm{~m}$ $(200 \mathrm{ft})$ from the eastward ends of the West Lock wing walls. The larger eddy in the West Lock approach allowed the tow to be slowed and steered into alignment with the lock without undue difficulty. 


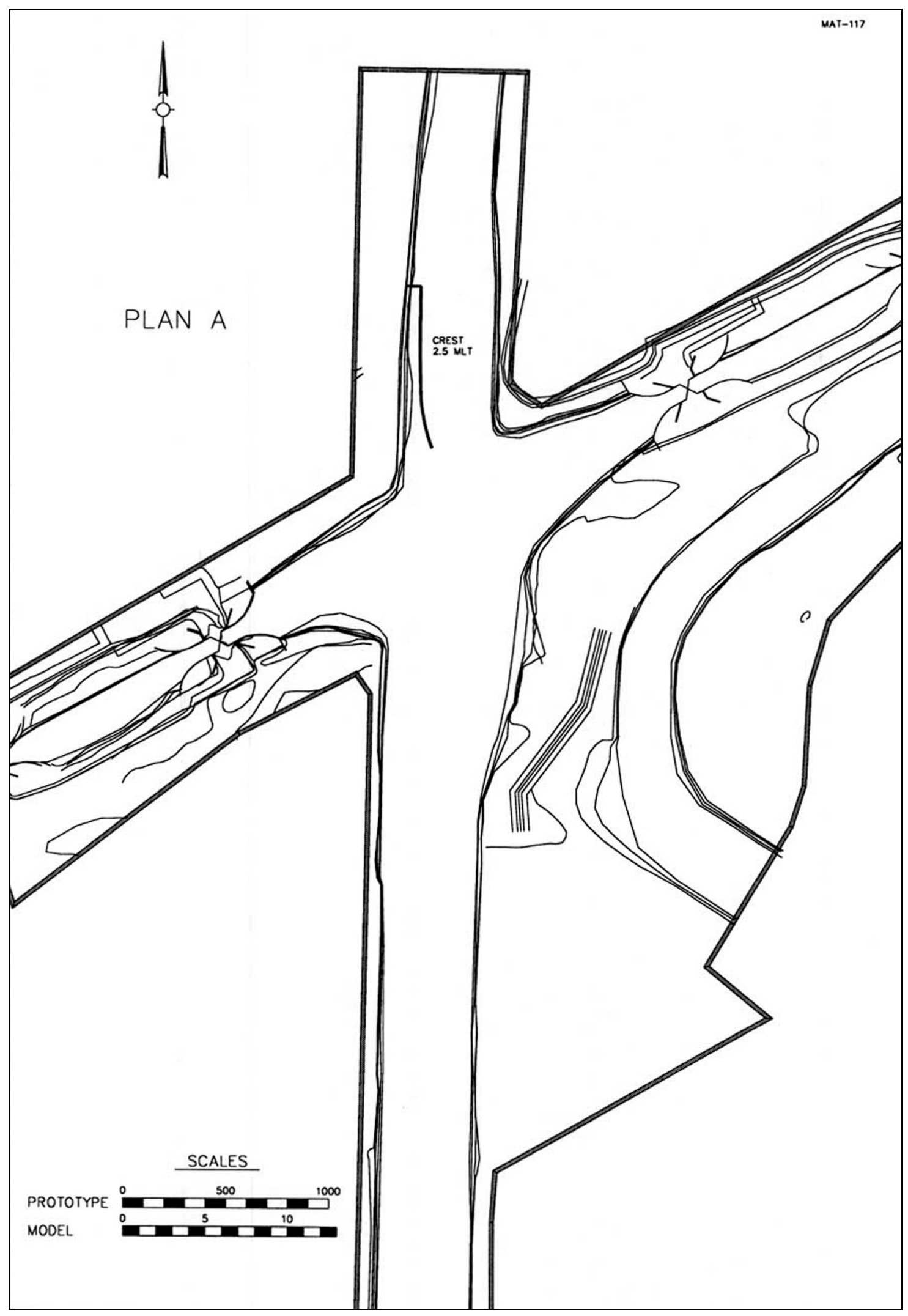

Figure 3. Plan A layout 
With tows moving west to east (Plate 23), the tow clears the lock chamber and can be steered into the currents. Again the set on the eastward half of the intersection is greater than with the base conditions. The stern of the tow passes out of the current set as the head of the tow reaches the western ends of the East Lock wing walls. The tow can then be slowed and maneuvered to align with the lock with no major difficulty.

For the $283 \mathrm{cu} \mathrm{m} / \mathrm{s}(10,000 \mathrm{cfs})$ flow condition and tows moving east to west (Plate 24), the tow again comes slowly out of the East Lock and takes advantage of the counterclockwise eddy to push the head of the tow northward. As the head of the tow passes the northeast corner, the tow starts setting southward. As the head of the tow reaches the eddy in the West Lock approach, the set on the head diminishes. This allows the stern of the tow to be steered hard left into the current earlier than with the base conditions. The stern of the tow comes into the slack currents in the West Lock approach as the head is just reaching the eastern ends of the West Lock wing walls. The tow can then be steered into alignment to enter the lock with moderate difficulty. Placement of the head of the tow slightly north or south of the GIWW center line is not quite as critical as with the base conditions, since the tow is completely out of the currents and more maneuverable just before the head of the tow comes inside the West Lock wing walls.

With the $283 \mathrm{cu} \mathrm{m} / \mathrm{s}(10,000 \mathrm{cfs})$ flow condition and tows moving west to east (Plate 25), the tow can completely clear the constraint of the lock and wing walls and be steered northward into the current before reaching the crosscurrents. As the head of the tow comes into the crosscurrent, the tow starts setting southward and the stern is steered hard left to control the set. As the head of the tow passes eastward of the northeast corner, the set on the head of the tow diminishes and the stern can be steered hard right to hold up against the current set. The stern comes out of the current set as it passes the northeast corner and the head of the tow is entering between the East Lock wing walls. Positioning of the head on the center line of the GIWW is slightly more critical than with the base conditions since there is a slight reduction in the distance that the eddy in the East Lock approach extends from the East Lock, limiting maneuvering room before the head of the tow comes inside the 22.9-m $(75-\mathrm{ft})$ width section between the wing walls.

This plan was installed in the model and presented to representatives of navigation industry users in meetings during 16 and 17 September 1998. The representatives of the towing industries did not feel that the extra maneuvering room gained in the West Lock approach was enough to offset concerns about the increased current speed and additional set experienced along the left side of the intersection. They also were concerned that any improvements made on east to west travel might come at the expense of slightly increased difficulty in west to east travel. There were also concerns that a fixed structure could become a hazard to navigation. There were no attempts made to turn a tow coming out of the East Lock into the Colorado River, so this might also be a concern. 


\section{Plan B - Dredging Intersection}

\section{Description}

The Galveston District proposed a plan to provide an increased crosssectional area in the intersection to compensate for lost flow area during the passage of a tow. This plan called for dredging the intersection of the Colorado/ Diversion Channel starting in the Colorado River approximately $246.9 \mathrm{~m}(810 \mathrm{ft})$ upstream of the center line of the GIWW with a $30.5-\mathrm{m}-(100-\mathrm{ft}-)$ wide cut. This cut started at the existing bed elevation of approximately -12 mlt and went down on a 1 to 25 slope to $-25 \mathrm{mlt}$, then widened along the next $121.9 \mathrm{~m}$ (400 ft) from 30.5 to $61.0 \mathrm{~m}$ (100 to $200 \mathrm{ft})$. The $61.0-\mathrm{m}$ - (200-ft-) width carried downstream for $152.4 \mathrm{~m}(500 \mathrm{ft})$ at $-25 \mathrm{mlt}$, then, using a 1 on 25 slope, went back up to the existing bed elevation of approximately $-12 \mathrm{mlt}$ in the Diversion Channel (Figure 4).

\section{Results}

Current directions and velocities. With the $170 \mathrm{cu} \mathrm{m} / \mathrm{s}(6,000 \mathrm{cfs})$ flow condition (Plate 26) velocities along the left descending bank of the Colorado were up to $0.73 \mathrm{~m} / \mathrm{s}(2.4 \mathrm{fps}), 0.55 \mathrm{~m} / \mathrm{s}(1.8 \mathrm{fps})$ near the center of the intersection, and generally about 0.46 to $0.55 \mathrm{~m} / \mathrm{s}$ ( 1.5 to $1.8 \mathrm{fps}$ ) in the Diversion Channel. A small counterclockwise eddy formed in the East Lock approach and a clockwise eddy formed in the West approach. Flow through the intersection appeared to concentrate over the dredged channel and the eddy in the West Lock extended further eastward than with the base conditions.

With the $283 \mathrm{cu} \mathrm{m} / \mathrm{s}(10,000 \mathrm{cfs})$ flow condition (Plate 27) velocities in the Colorado near the left bank reached up to $0.91 \mathrm{~m} / \mathrm{s}(3.0 \mathrm{fps}), 0.64 \mathrm{~m} / \mathrm{s}(2.1 \mathrm{fps})$ in the center of the intersection and approximately $0.61 \mathrm{~m} / \mathrm{s}(2.0 \mathrm{fps})$ near the entrance to the Diversion Channel. The counterclockwise eddy in the East Lock approach is somewhat slower than with the base conditions and there is no significant eddy at all in the West Lock approach. The currents tend to follow the direction of the dredge cut through the intersection, slightly more westward than with the base conditions.

Navigation conditions. With the $170 \mathrm{cu} \mathrm{m} / \mathrm{s}(6,000 \mathrm{cfs})$ flow condition and the tow moving east to west (Plate 28), navigation conditions are very similar to the base conditions. The tow experienced some set as it got well out into the intersection, but not quite as much as with the base conditions. This was also true with the tows moving west to east (Plate 29).

With the $283 \mathrm{cu} \mathrm{m} / \mathrm{s}(10,000 \mathrm{cfs})$ flow condition and tows moving east to west (Plate 30) the tow moved from the East Lock and out into the intersection with less set than with the base conditions. This made getting into alignment for entering the West Lock less difficult. With the tows moving west to east (Plate 31), the amount of set was also reduced, making getting into alignment with the East Lock less difficult than the base conditions. 


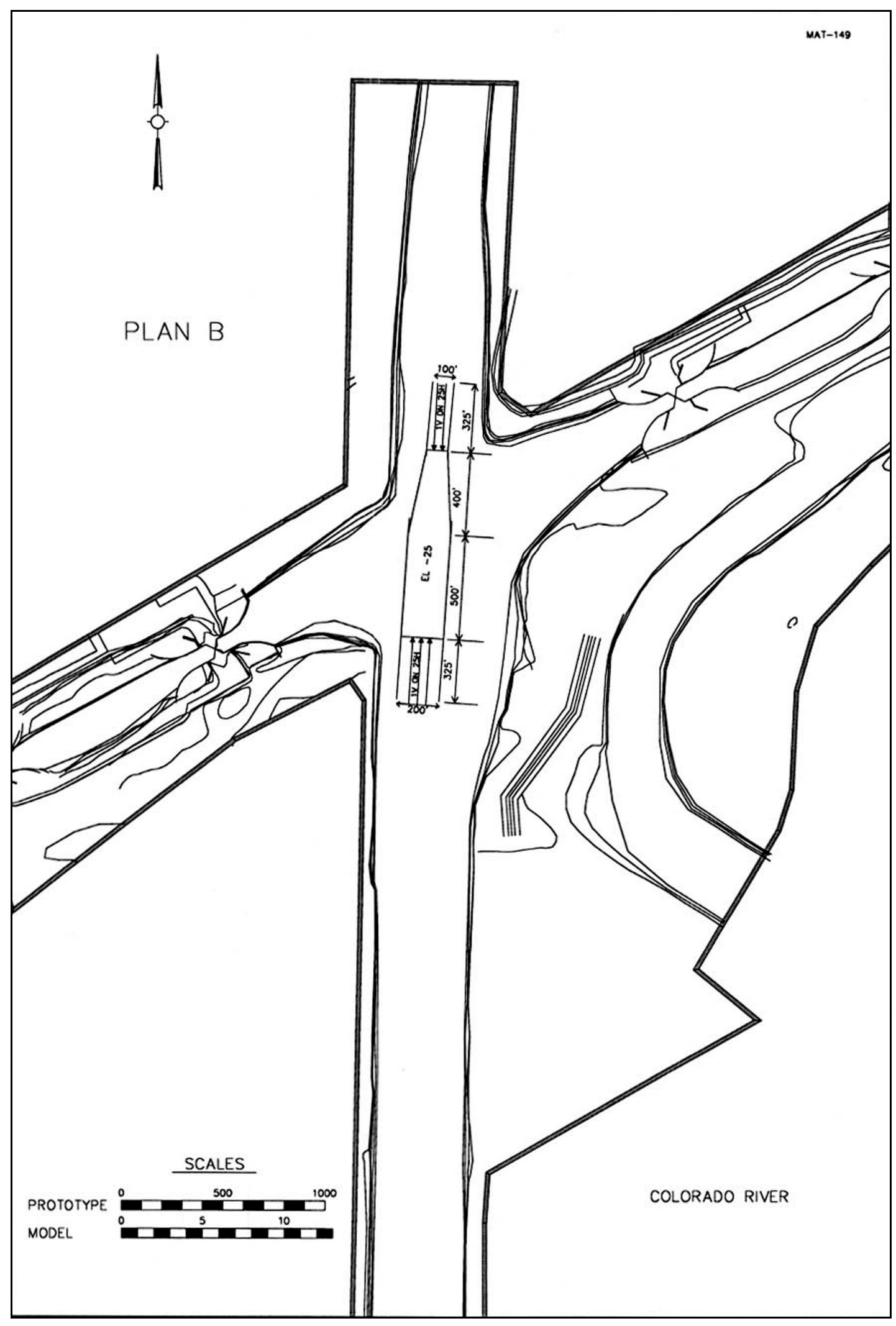

Figure 4. Plan B layout 
The difficulty of making the runs with this plan, either east to west or west to east, was less than compared to the $283 \mathrm{cu} \mathrm{m} / \mathrm{s}(10,000 \mathrm{cfs})$ base conditions, but greater when compared to the $170 \mathrm{cu} \mathrm{m} / \mathrm{s}(6,000 \mathrm{cfs})$ base conditions. It

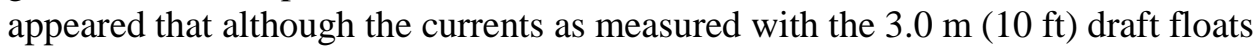
were not significantly changed between the base conditions and Plan B, the additional cross-sectional area allowed more flow to go underneath the tow, as indicated by the point velocities, and reduced the current's effect on the tow as it crossed the intersection.

Velocities in the intersection. While this plan was in the model, the Galveston District requested that point velocities be taken in the intersection with a loaded, three-barge tow across the intersection with the dredging in place and also with the predredged channel in place. This was done to determine how much the flow was influenced by the channel dredging. To accomplish this, the three-barge tow was tied in place across the intersection where it most fully blocked the flow coming down the Colorado, angled slightly upstream into the flow, and positioned approximately where it would typically be during a transit from east to west. An acoustic Doppler velocity meter was used to collect velocities at stations $30.5 \mathrm{~m}$ (100 ft) upstream and downstream of the tow. Velocities were taken on the right and left edges and the center of the dredge cut at depths of $2.4,4.3$, and $6.7 \mathrm{~m}(8,14$, and $22 \mathrm{ft})$ below the water surface with flow conditions of 170 and $283 \mathrm{cu} \mathrm{m} / \mathrm{s}(6,000$ and 10,000 cfs). After this was completed, the dredged cut was filled with sand and coated with a thin layer of cement to the bed configuration of the 1997 survey. The same information was collected at the same stations, except for velocities at a $6.7-\mathrm{m}-(22-\mathrm{ft}-)$ depth, which does not exist with the undredged channel. The velocity vectors indicate the relative angle the velocities were moving. The magnitudes of the velocities are recorded in feet per second (fps). The arrowhead points are the actual position of the velocity measurements.

Velocities with the $170 \mathrm{cu} \mathrm{m} / \mathrm{s}(6,000 \mathrm{cfs})$ flow condition (Figures 5-14) indicate that the dredging did not affect the currents at the $2.4-\mathrm{m}-(8-\mathrm{ft}-)$ depth to any significant degree. At the 4.3-m- (14-ft-) depth, velocities with the dredged channel showed a significant increase over the undredged channel. Velocities near the bottom of the dredged cut were only slightly less than at the $4.3-\mathrm{m}-$ (14-ft-) depth level. With the $283 \mathrm{cu} \mathrm{m} / \mathrm{s}(10,000 \mathrm{cfs})$ flow condition (Figures 10-14) there was a pronounced drop in velocities upstream of the tow at the 2.4-m- (8-ft-) depth with the dredged channel, especially along the right descending side of the dredge cut. Velocities at the 4.3-m- (14-ft-) depth were much greater both upstream and downstream with the dredged cut. As with the $170 \mathrm{cu} \mathrm{m} / \mathrm{s}(6,000 \mathrm{cfs})$ flow condition, the velocities near the bottom of the dredge cut were very similar to those recorded at the 4.3-m- (14-ft-) depth.

\section{Plan B-1 - Dredging and L-Head Dike}

\section{Description}

The Colorado River carries a heavy sediment load and the dredged intersection would likely be subject to shoaling. Shoaling problems are 


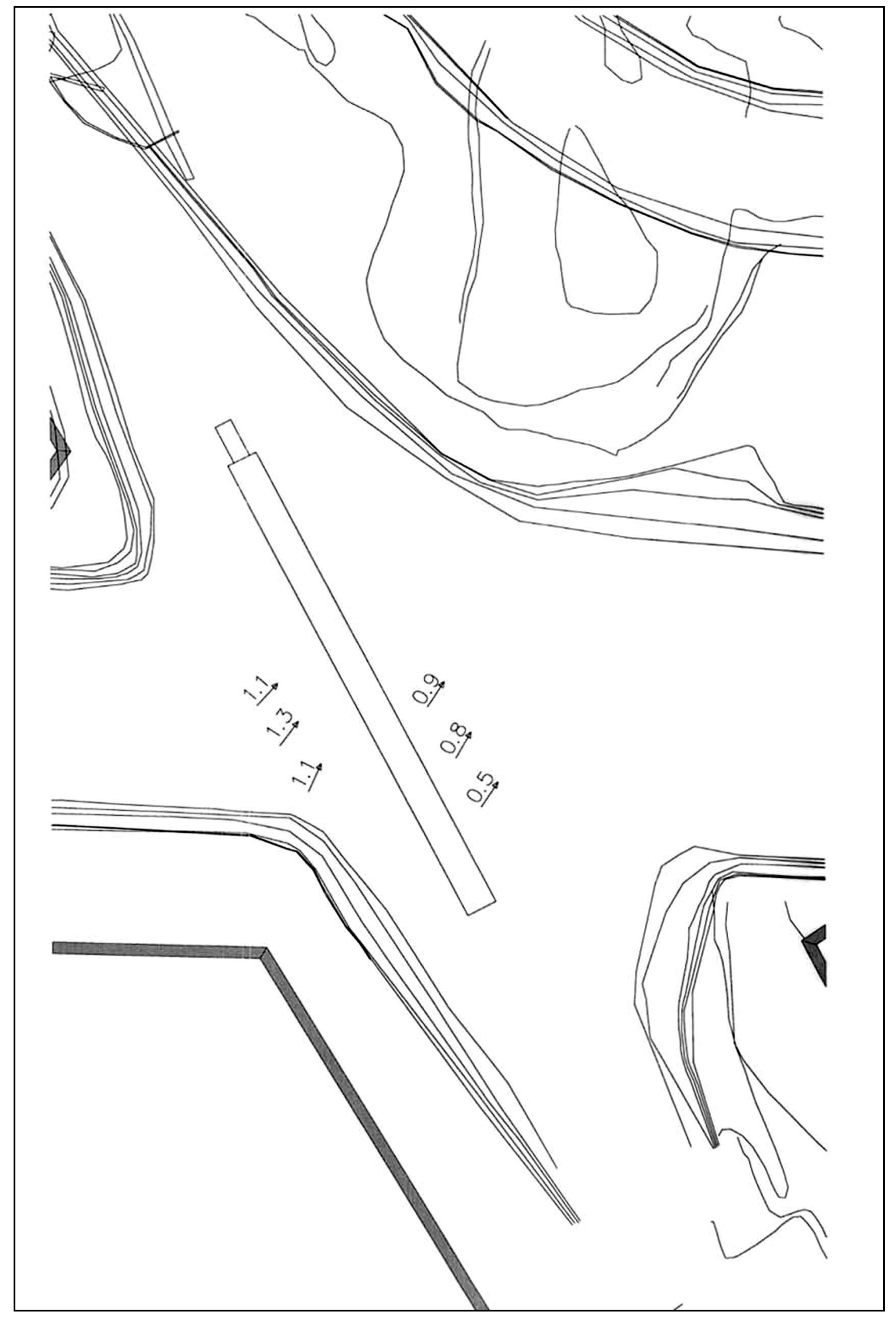

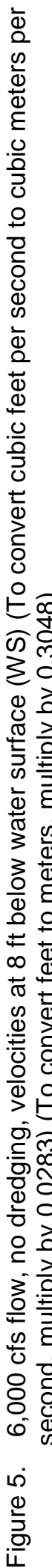




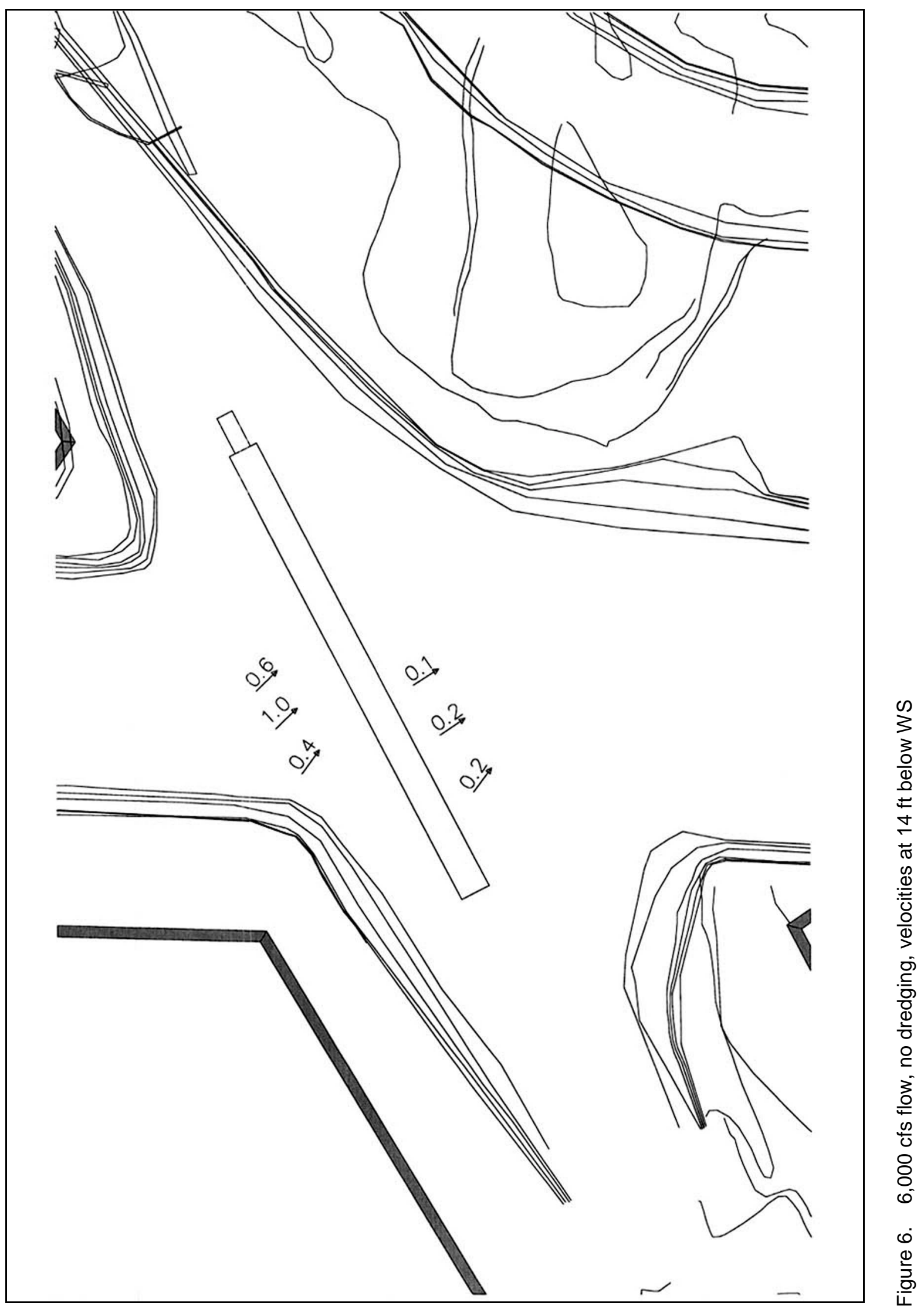




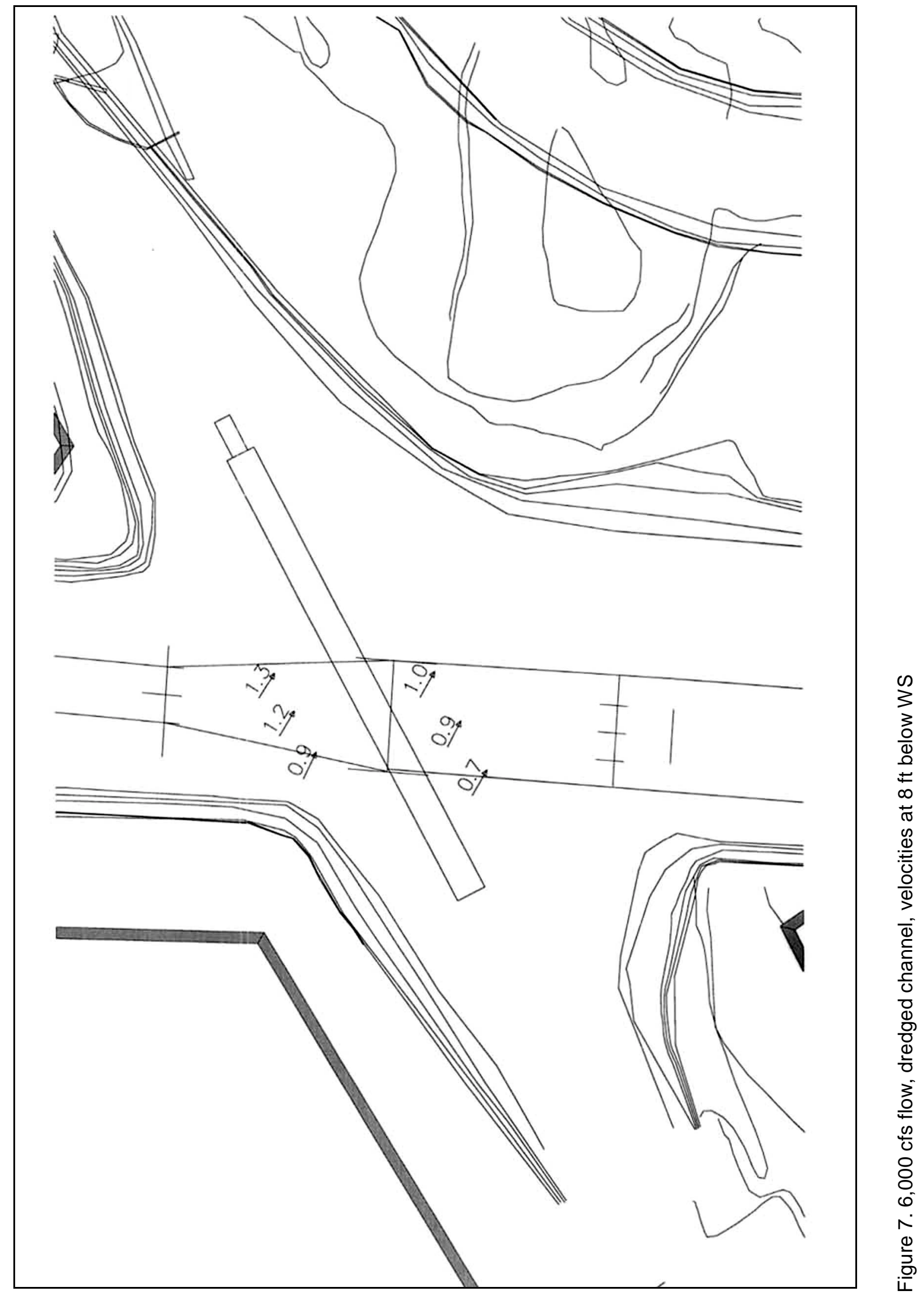




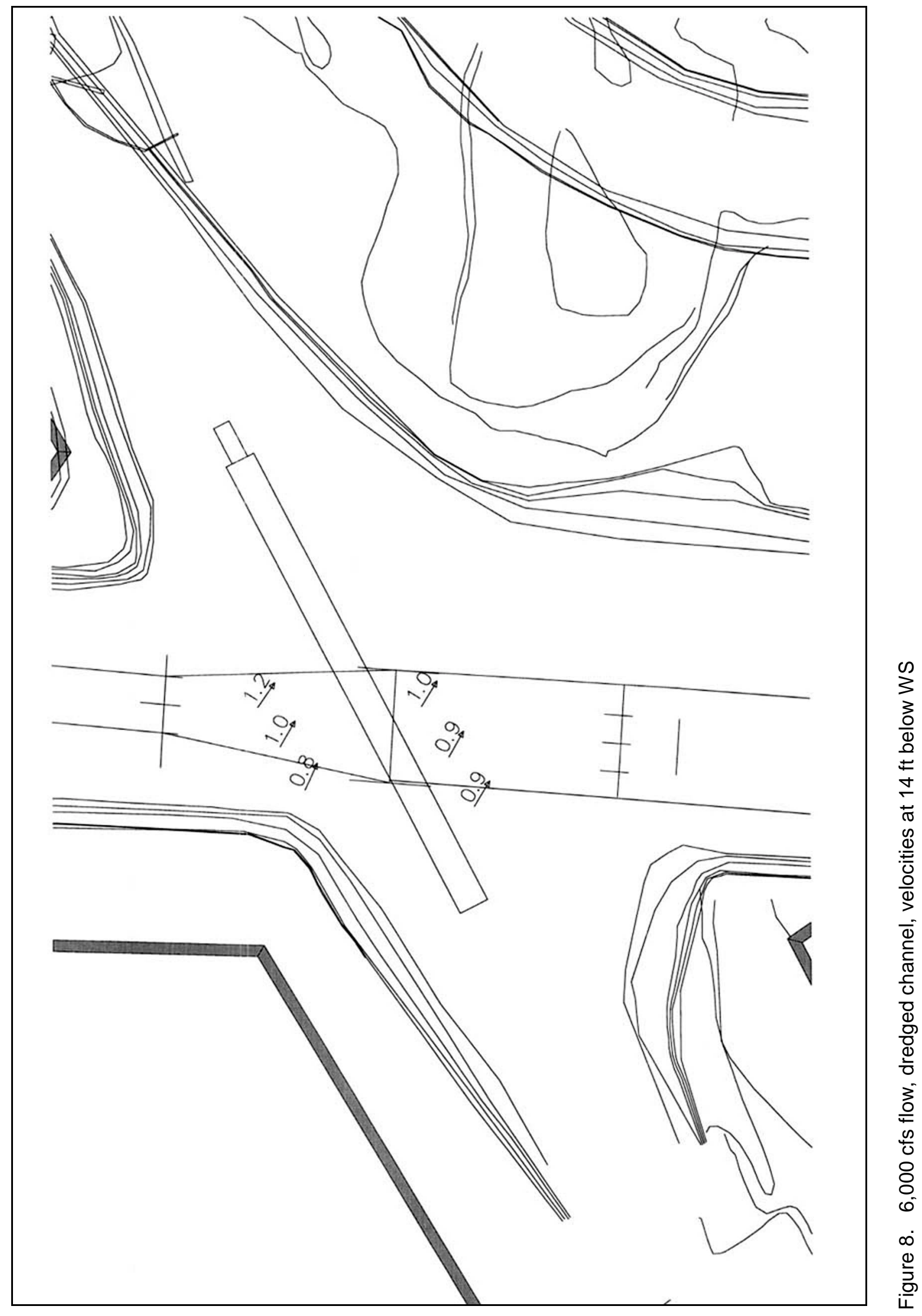




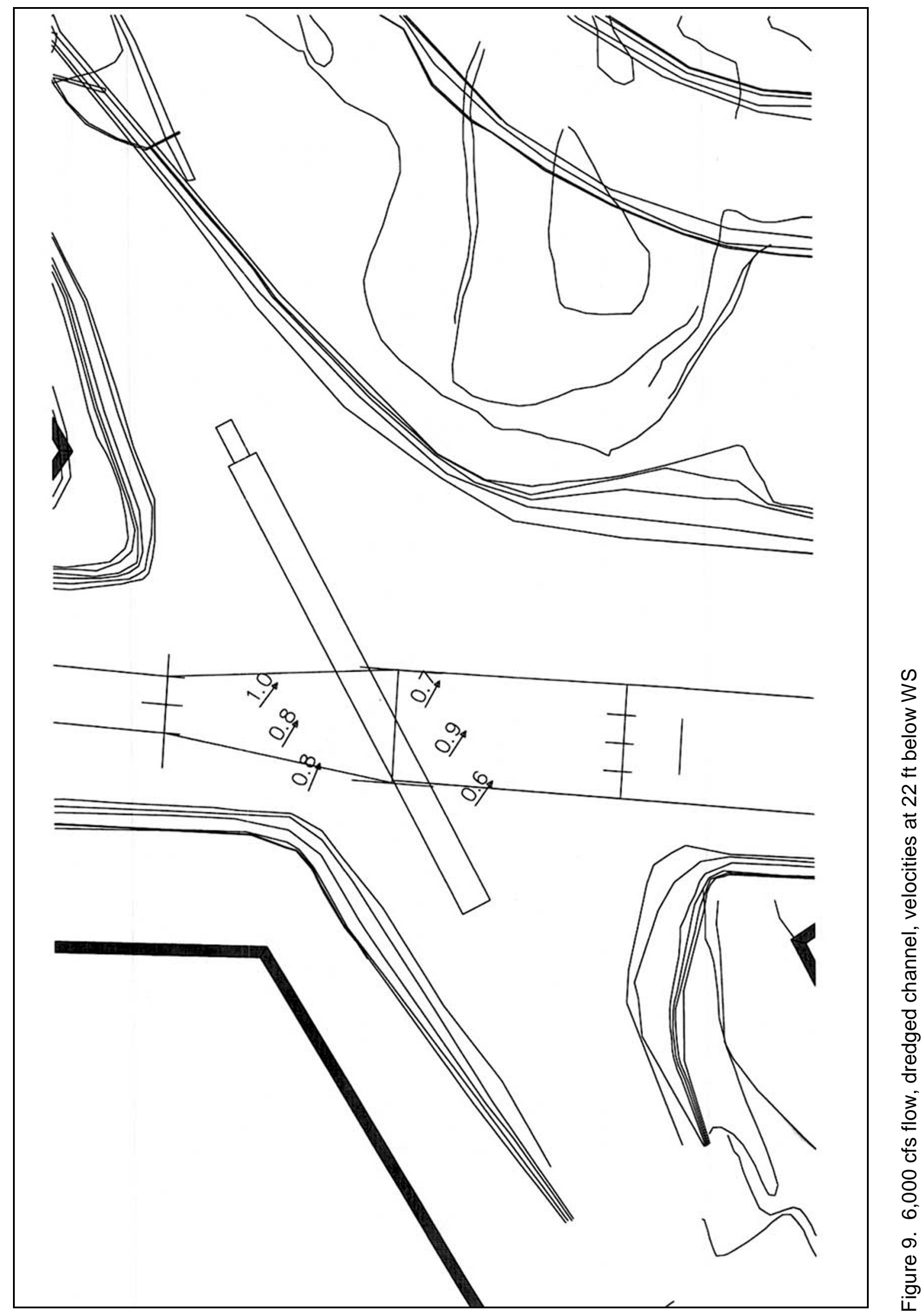




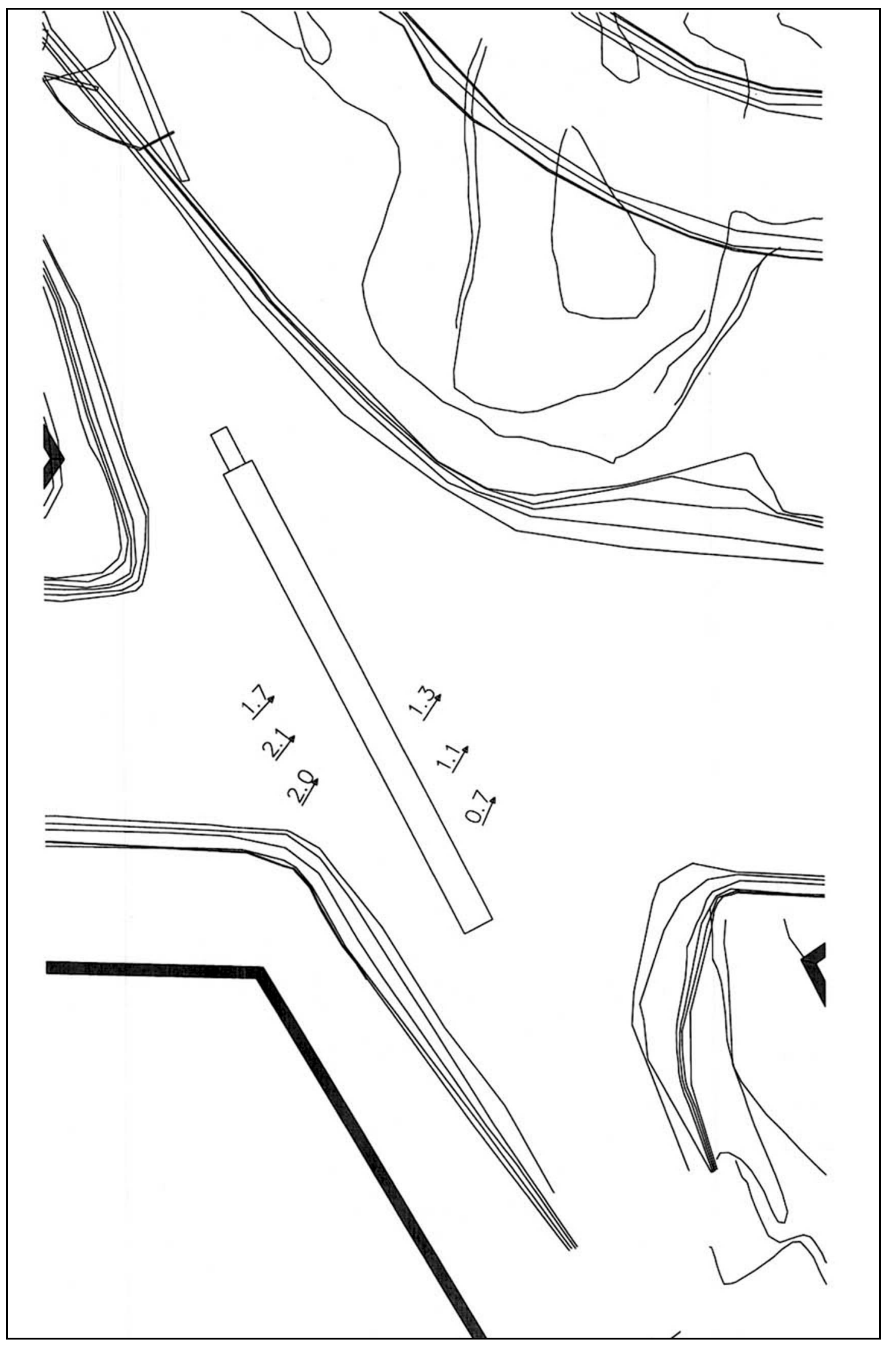

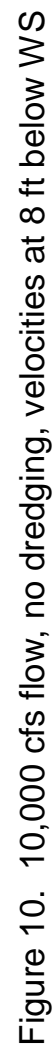




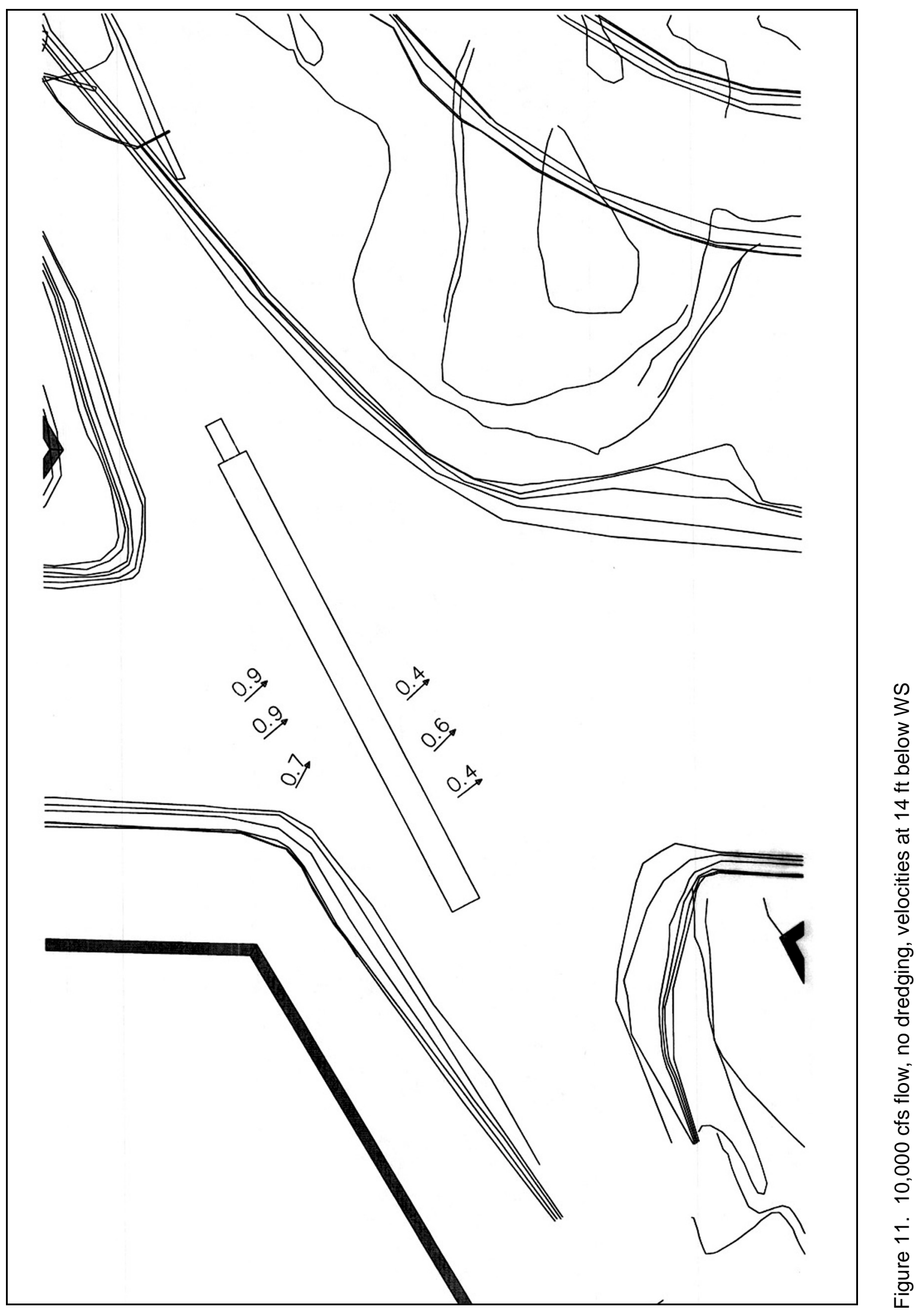




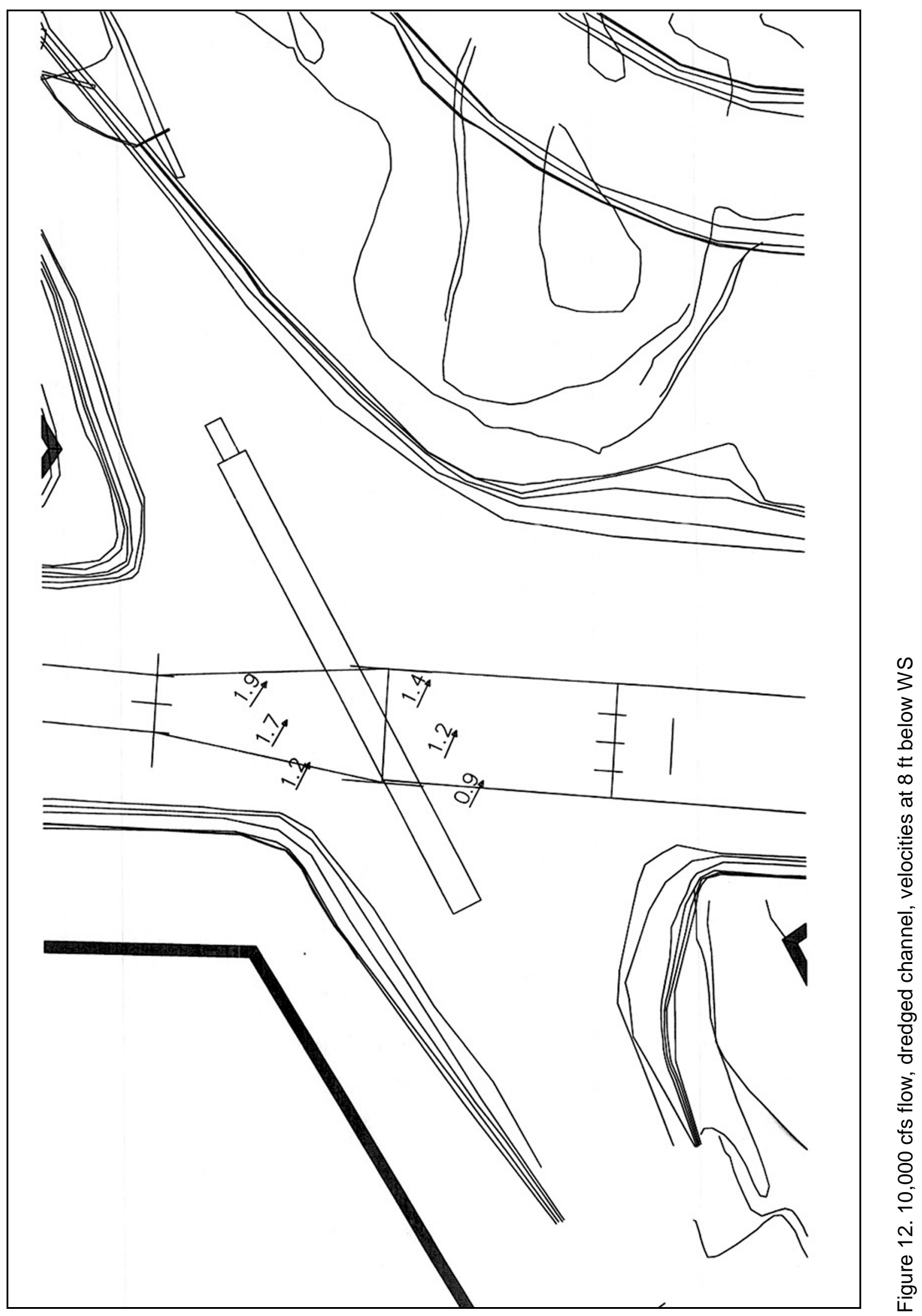




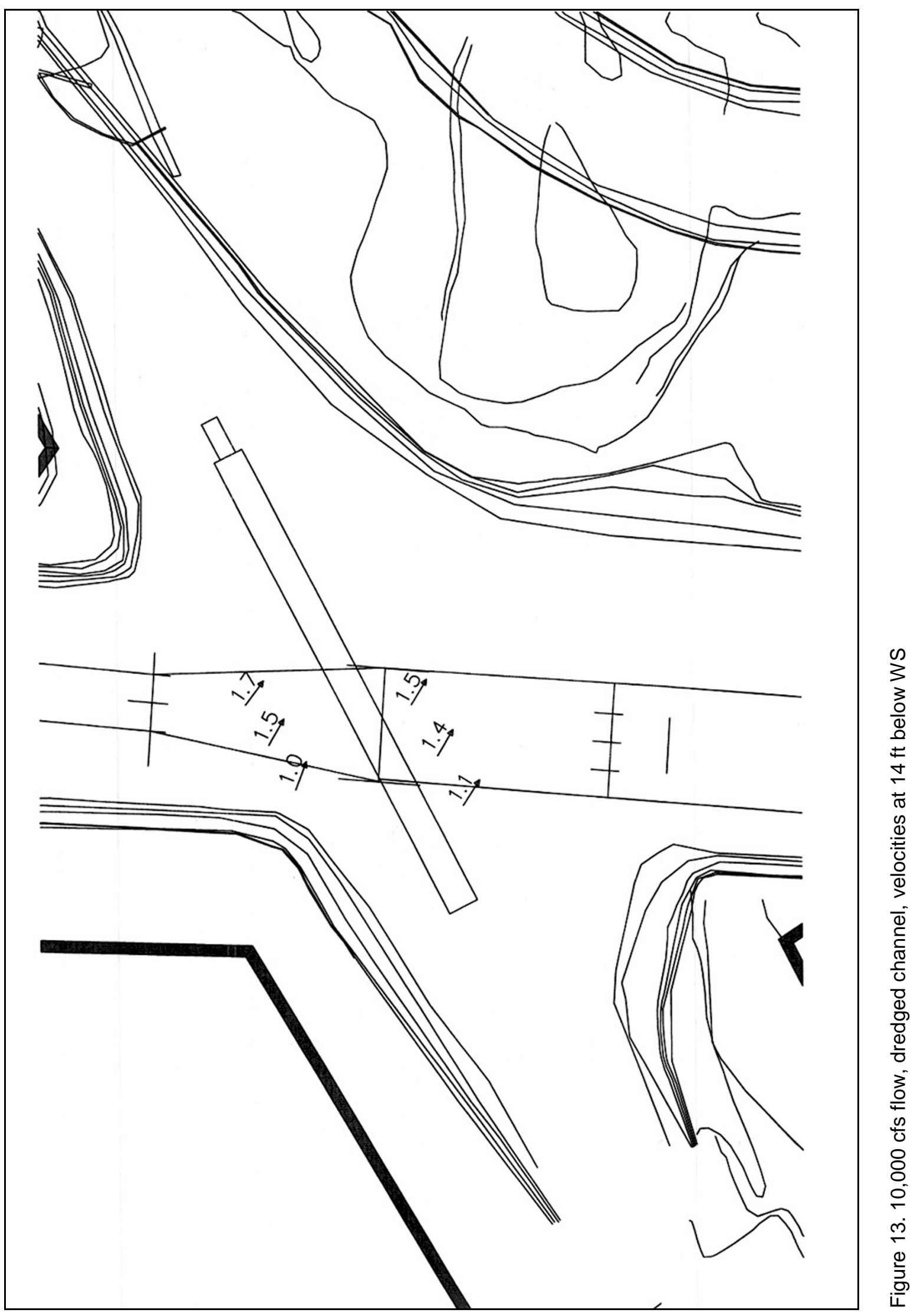




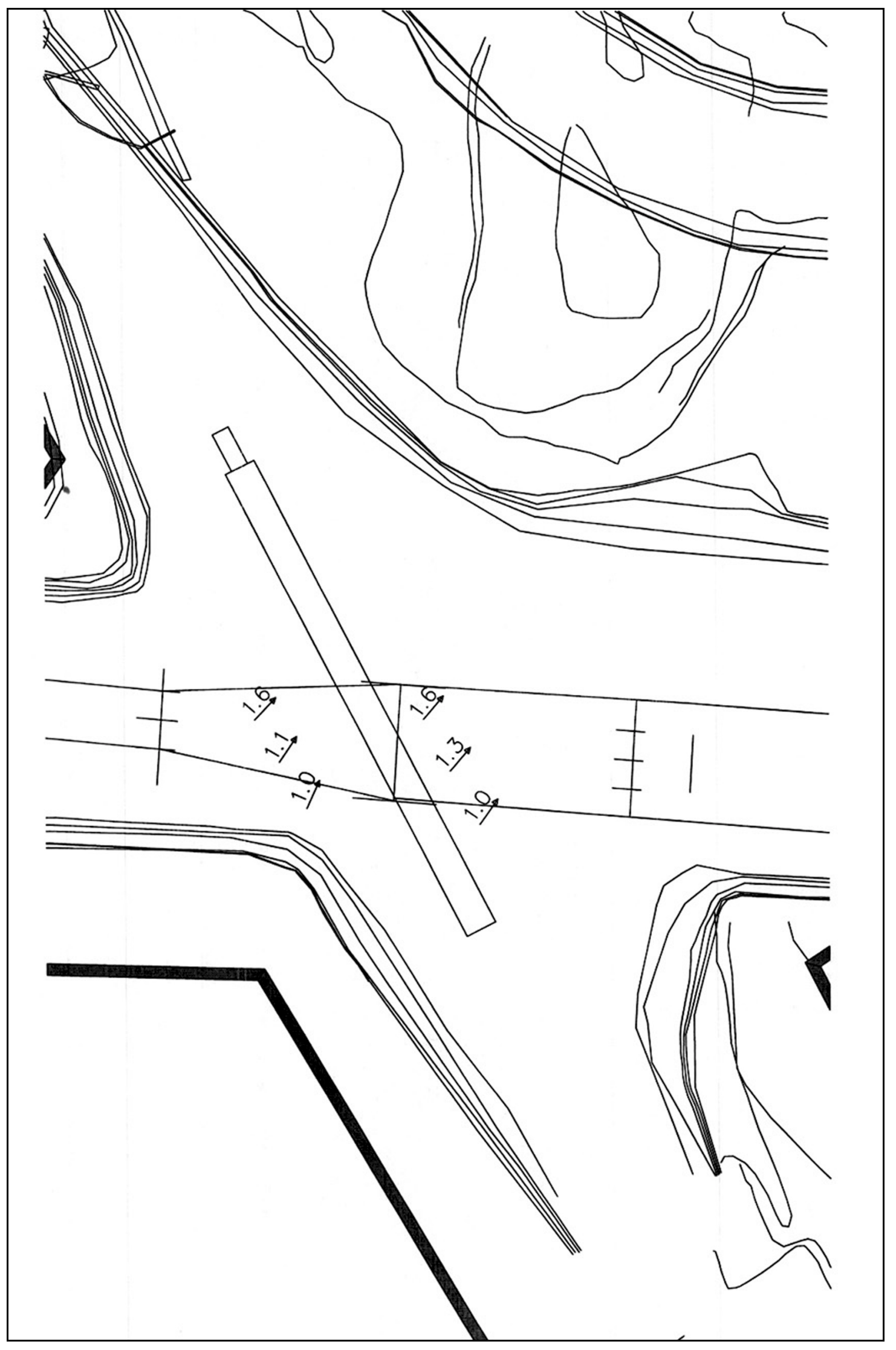

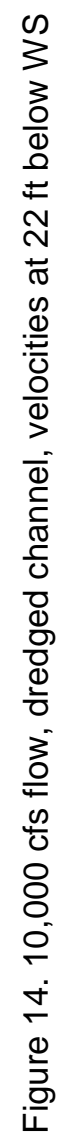


commonly controlled by the use of contraction works, similar to the L-head dike as evaluated in Plan B. Although this model could not address the effectiveness of this dike in maintenance of the deepened channel in the intersection, it could be used to evaluate how the combination of a training structure and dredging might affect navigation. Plan B-1 (Figure 15) consisted of the dredged channel as used for Plan B and the L-head dike as used for Plan A.

\section{Results}

Current directions and velocities. With the $170 \mathrm{cu} \mathrm{m} / \mathrm{s}(6,000 \mathrm{cfs})$ flow condition (Plate 32) velocities along the left descending bank of the Colorado were up to $0.73 \mathrm{~m} / \mathrm{s}$ (2.4 fps), $0.58 \mathrm{~m} / \mathrm{s}$ (1.9 fps) near the center of the intersection, and generally about 0.47 to $0.55 \mathrm{~m} / \mathrm{s}$ (1.6 to $1.8 \mathrm{fps})$ in the Diversion Channel. A small counterclockwise eddy formed in the East Lock approach and a small, slow clockwise eddy formed in the West approach. Flow through the intersection appeared to concentrate over the dredged channel, and the eddy in the West Lock extended further eastward than with the base conditions.

With the $283 \mathrm{cu} \mathrm{m} / \mathrm{s}(10,000 \mathrm{cfs})$ flow condition (Plate 33), velocities in the Colorado near the left bank reached up to $1.04 \mathrm{~m} / \mathrm{s}(3.4 \mathrm{fps}), 0.82 \mathrm{~m} / \mathrm{s}(2.7 \mathrm{fps})$ in the center of the intersection and approximately 0.61 to $0.76 \mathrm{~m} / \mathrm{s}$ (2.0 to $2.5 \mathrm{fps})$ in the Diversion Channel. The counterclockwise eddy in the East Lock approach was somewhat slower than with the base conditions and there were two slow, counterrotating eddies in the West Lock approach. The currents tended to follow the direction of the dredge cut through the intersection and were concentrated slightly more eastward than with the base conditions.

Navigation conditions. With the $170 \mathrm{cu} \mathrm{m} / \mathrm{s}(6,000 \mathrm{cfs})$ flow condition and the tow moving east to west (Plate 34), navigation conditions were similar to that with the Plan B conditions. The tow experienced a significant set as it moved further into the intersection, but was able to get into alignment with the West Lock when the stern got into the near slack currents along the western edge of the intersection. For tows moving west to east (Plate 35), the head of the tow could be turned northward before the head reached the crosscurrents. The set as the tow came into the intersection was not excessive or difficult to manage and getting into alignment to enter the East Lock was not overly difficult.

With the $283 \mathrm{cu} \mathrm{m} / \mathrm{s}(10,000 \mathrm{cfs})$ flow condition and tows moving east to west (Plate 36), the tow moved from the East Lock and out into the intersection with somewhat less set than noted with the base conditions. Getting into alignment for entering the West Lock was somewhat less difficult since the amount of set was reduced and the slow clockwise eddy in the West Lock approach extended slightly further eastward than with the base conditions. This allowed the stern to get out of the crosscurrents before the head of the tow got within the West Lock wing walls. With the tows moving west to east (Plate 37), the head of the tow could be turned northward before coming into the crosscurrents. The amount of set is similar to that with the Plan B condition and the difficulty in getting aligned and into the East Lock is also about the same as with Plan B conditions. The difficulty of making the runs either east to west or west to east is 


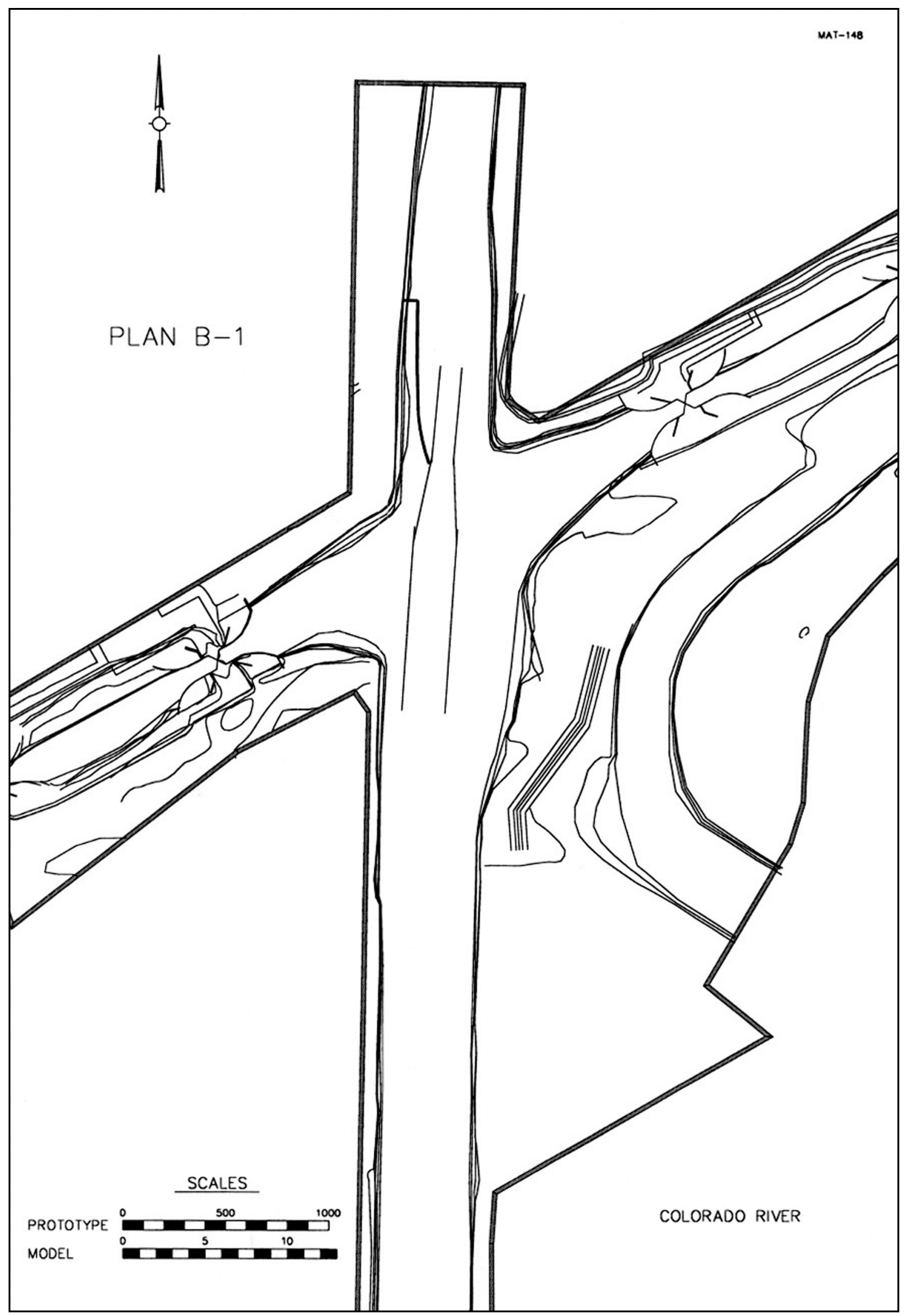

Figure 15. Plan B-1 layout 
somewhat less than with the $283 \mathrm{cu} \mathrm{m} / \mathrm{s}(10,000 \mathrm{cfs})$ base conditions, but slightly more difficult than with just the dredging of Plan B.

This plan would involve construction of a fixed training work which might be considered as a navigation hazard by the towing industry. As with Plan B, evaluation of a tow turning from the East Lock into the Colorado River was not performed and could be adversely affected.

\section{Flow through the East and West Locks}

\section{Description}

Preliminary evaluations of navigation conditions were made with the East Lock open with existing conditions at the sponsor's request prior to installation of Plan B and after removal of the L-head dike of Plan A. During that evaluation, the gates of the East Lock were opened, an ebbing $1.61 \mathrm{~km} / \mathrm{hr}(1.0 \mathrm{mph})$ flow was established in the GIWW/Bypass Channel, and the $283 \mathrm{cu} \mathrm{m} / \mathrm{s}$ $(10,000 \mathrm{cfs})$ flow condition was established in the Colorado River. The controlled stage in the GIWW, east of the East Lock was $3.0 \mathrm{mlt}$ and the stage in the Colorado was $2.5 \mathrm{mlt}$. This set up a flow east to west through the East Lock. For this preliminary evaluation, current directions and velocities were recorded only in the East Lock approach and about midway into the intersection.

During evaluation of Plan B, a question was raised of how flow through the West Lock while tow traffic was either entering from the east or exiting to the east would affect navigation. The model design assumed that flow through the West Lock was negligible and no means for passing flow through the lock was provided. To perform these evaluations, the Galveston District provided estimates of flow velocity in the West Lock chamber for flow conditions of 170 and $283 \mathrm{cu} \mathrm{m} / \mathrm{s}(6,000$ and 10,000 cfs). The velocities through the lock provided for these flow conditions are 0.31 and $0.61 \mathrm{~m} / \mathrm{s}$ ( $1.0 \mathrm{fps}$ and $2.0 \mathrm{fps})$, respectively. The model was configured for the existing conditions and the correct discharge and stage was maintained in the Colorado for the 170 and $283 \mathrm{cu} \mathrm{m} / \mathrm{s}(6,000$ and 10,000 cfs) flow conditions. A pump was placed at the far west end of the West Lock to draw water out of the lock. The pump had a valve in the outflow line that was used to regulate the discharge. The discharge of the pump was adjusted until surface current velocities entering the West Lock reached the required magnitude. Determination of the velocity was performed by timing paper confetti floating on the water surface over a known distance.

\section{Results}

Current directions and velocities. Current velocities with flow through the East Lock with the $283 \mathrm{cu} \mathrm{m} / \mathrm{s}(10,000 \mathrm{cfs})$ flow condition (Plate 38) show that flow through the East Lock eliminated the counterclockwise eddy in the East Lock approach and had velocities coming from the East Lock toward the intersection of from 0.31 to $0.43 \mathrm{~m} / \mathrm{s}$ (1.0 to $1.4 \mathrm{fps})$. 
Current velocities for the $170 \mathrm{cu} \mathrm{m} / \mathrm{s}(6,000 \mathrm{cfs})$ flow condition and flow through the West Lock (Plate 39) along the left descending bank line of the Colorado River immediately upstream of the intersection are up to $0.64 \mathrm{~m} / \mathrm{s}$ (2.1 fps), up to $0.53 \mathrm{~m} / \mathrm{s}(1.8 \mathrm{fps})$ in the center of the intersection, and approximately 0.37 to $0.43 \mathrm{~m} / \mathrm{s}$ (1.2 to $1.4 \mathrm{fps})$ in the Diversion Channel. A slow, counterclockwise eddy formed in the East Lock approach and an elongated clockwise eddy formed in the West Lock approach.

For the $283 \mathrm{cu} \mathrm{m} / \mathrm{s}(10,000 \mathrm{cfs})$ flow condition and flow through the West Lock (Plate 40), a velocity of up to $0.91 \mathrm{~m} / \mathrm{s}(3.0 \mathrm{fps})$ was recorded along the left bank of the Colorado, up to $0.79 \mathrm{~m} / \mathrm{s}(2.6 \mathrm{fps})$ in the center of the intersection and approximately 0.49 to $0.55 \mathrm{~m} / \mathrm{s}$ (1.6 to $1.8 \mathrm{fps}$ ) in the Diversion Channel. A large counterclockwise eddy formed in the East Lock approach. Flow comes out of the Colorado and runs almost straight into the West Lock. A small clockwise eddy formed between the north bank line just east of the West Lock and the center line of the GIWW.

Navigation conditions. For tows moving east to west with flow through the East Lock (Plate 41), the current through the lock made it more difficult to get the head of the tow turned northward into the current. With traffic moving west to east (Plate 42), the tow was slowed as it entered the East Lock approach by the currents coming from the lock, which exposed the tow to the crosscurrents coming down the Colorado River for a longer period, increasing the difficulty of the transit. Flow through the East Lock increased the difficulty of navigation for tows in both directions. The level of difficulty of transits without flow through the lock during the $283 \mathrm{cu} \mathrm{m} / \mathrm{s}(10,000 \mathrm{cfs})$ flow condition was considered to be more representative of the normal navigation conditions. Flow through the lock presented a more extreme condition that could be evaluated if plan proposals provided significant improvements for the less extreme, but still difficult navigation conditions with no flow through the locks.

With the $170 \mathrm{cu} \mathrm{m} / \mathrm{s}(6,000 \mathrm{cfs})$ flow condition, flow through the West Lock, and tows moving east to west (Plate 43), passage out of the East Lock and through the intersection was the same as with the West Lock gates closed. Flow through the West Lock tended to help draw the head of the tow into alignment with the lock and made the transit from the center of the intersection into the lock somewhat less difficult than with no flow through the lock. With the tow moving west to east (Plate 44), the speed the tow could attain exiting the lock was reduced by the flow coming into the lock. This reduced the speed the tow entered the intersection, causing the tow to be exposed for a longer time to the crosscurrents. This produced a greater set than noted with no flow through the West Lock, making it more difficult to get into alignment to enter the East Lock.

With the $283 \mathrm{cu} \mathrm{m} / \mathrm{s}(10,000 \mathrm{cfs})$ flow condition, flow through the West Lock, and tows moving east to west (Plate 45), passage out of the East Lock and into the intersection was the same as with no flow through the West Lock. As noted with the $170 \mathrm{cu} \mathrm{m} / \mathrm{s}(6,000 \mathrm{cfs})$ flow condition, the current being pulled into the lock also tended to pull the head of the tow into the lock. This again made entering the West Lock somewhat less difficult than with no flow through the lock. With the tows moving west to east (Plate 46), the current coming into 
the lock forced the tow to come out of the lock very slowly. It was extremely difficult to turn the tow into the current and the slow exit speed from the lock also slowed the crossing time across the intersection, exposing the tow longer to the crosscurrents. It was very difficult to hold first the head of the tow up into the current, then the stern as it passed into the intersection. This in turn made it difficult to get aligned into the East Lock, much more so than with no flow through the West Lock.

\section{Plan C - Reconstruction of Southwest Corner}

\section{Description}

Representatives of the towing industry and tow pilots made statements during the course of this study that navigation conditions between the East and West Locks was not nearly so difficult prior to the dredging of the Diversion Channel and damming of the old Colorado River Channel. They also made statements that transits were not as difficult even shortly after the Diversion Channel was opened. They did note that the southwest corner of the intersection of the Colorado River and GIWW soon started eroding and navigation conditions got worse shortly thereafter. The erosion of the point has been of considerable concern to the towing industry. This corner provides a landing point to work off of if the tow cannot get into alignment to get into the West Lock. At the start of this study, it was estimated that only about $42.67 \mathrm{~m}$ (140 ft) of the bank line that extended from the south wing wall of the West Lock toward the intersection remained. To determine how this bank line would affect present navigation conditions, the bank line along the southwest corner was restored to the 1980 survey conditions (Figure 16).

After completion of the navigation study, a study was conducted to determine if there are measures that can be taken to provide erosion resistance to the Southwest Corner without providing potential dangers to tows that would occasionally strike or rub along it. This work will help determine if the Southwest Corner can be enhanced and maintained in a cost-effective manner and with no increase of danger to tow traffic. The results of this study are attached to this report as Appendix A.

\section{Results}

Current directions and velocities. For the $170 \mathrm{cu} \mathrm{m} / \mathrm{s}(6,000 \mathrm{cfs})$ flow condition (Plate 47), velocities in the Colorado along the left descending bank line were up to $0.67 \mathrm{~m} / \mathrm{s}(2.2 \mathrm{fps}), 0.53 \mathrm{~m} / \mathrm{s}(1.7 \mathrm{fps})$ near the center of the intersection, and generally about 0.52 to $0.61 \mathrm{~m} / \mathrm{s}(1.7$ to $2.0 \mathrm{fps})$ past the southwest corner and into the Diversion Channel. A large, slow counterclockwise eddy formed in the East Lock approach and a large, slow clockwise eddy formed in the West Lock approach. The current direction showed a slight tendency toward the left descending bank line of the Diversion Channel. 


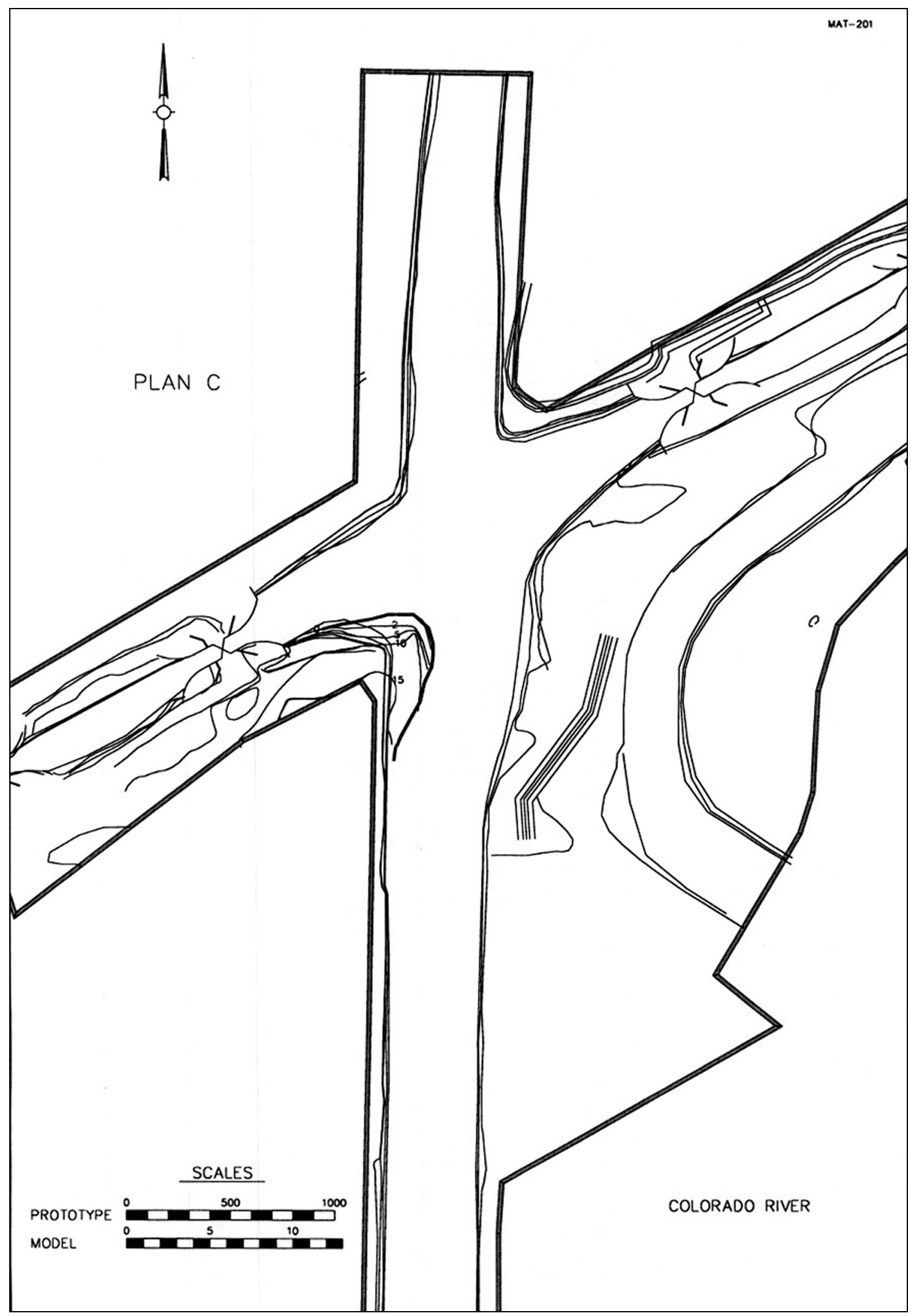

Figure 16. Plan C layout 
For the $283 \mathrm{cu} \mathrm{m} / \mathrm{s}(10,000 \mathrm{cfs})$ flow condition (Plate 48), velocities in the Colorado were up to $0.91 \mathrm{~m} / \mathrm{s}$ ( $3.0 \mathrm{fps}), 0.67 \mathrm{~m} / \mathrm{s}(2.2 \mathrm{fps})$ in the center of the intersection, and from 0.73 to $0.85 \mathrm{~m} / \mathrm{s}$ ( 2.4 to $2.8 \mathrm{fps}$ ) off the southwest corner and downstream into the Diversion Channel. A slow counterclockwise eddy formed in the East Lock approach adjacent to the intersection and caused a small, slow clockwise eddy to form on its eastward side. A large, slow clockwise eddy formed in the West Lock approach. Currents showed a definite shift toward the left descending bank of the Diversion Channel because of the protrusion of the enlarged southwest point.

Navigation conditions. Tow runs performed with the $283 \mathrm{cu} \mathrm{m} / \mathrm{s}$ $(10,000 \mathrm{cfs})$ flow condition and the tow moving from east to west (Plate 49) indicate conditions to be very similar to that of the base conditions. Currents along the right descending bank line of the Colorado and into the intersection are almost unaffected by the enlarged southwest point. The change of direction of the current occurred mostly eastward of the southwest point and south of the track of the tows. Currents in the intersection along the path the tows must take were practically the same as the base conditions and therefore navigation conditions were about the same. The use of the enlarged southwest point for the tow to use as a "landing zone" if the tow could not get into alignment with the West Lock and the ability of a tow to work off this bank line and into the lock could not be evaluated in this model. For tows moving west to east (Plate 50), navigation conditions are again almost the same as with the base conditions with no appreciable increase or decrease in navigation difficulty noted. To expedite the study, evaluation with the $170 \mathrm{cu} \mathrm{m} / \mathrm{s}(6,000 \mathrm{cfs})$ flow condition was not performed since navigation conditions using the enlarged southwest point and the $283 \mathrm{cu} \mathrm{m} / \mathrm{s}(10,000 \mathrm{cfs})$ flow condition were almost totally unchanged as compared with the base conditions.

\section{Plan D - Training Structures for GIWW/Bypass Improvements}

\section{Description}

To determine if placement of training structures could improve navigation conditions between the Matagorda Bridge, Bypass Channel, and East Lock, a series of structures were temporarily placed in the model in various positions, elevations, and combinations of more than one structure. Dye and confetti were then put in the model to observe how the structures affected the current patterns and if these effects might improve navigation conditions. When the dye and confetti indicated possible improvements, then the model tow was operated to observe the effects on the tow. These preliminary evaluations were performed using the maximum ebb and flood tide conditions of up to $4.05 \mathrm{~km} / \mathrm{hr}(2.5 \mathrm{mph})$ $[1.16 \mathrm{~m} / \mathrm{s}(3.8 \mathrm{fps})]$. From these preliminary evaluations, a plan was developed which consisted of installing a spur dike, perpendicular to the GIWW center line, $152 \mathrm{~m}$ (500 ft) westward of the center line of the Matagorda Bridge, with an elevation of $3.0 \mathrm{mlt}$ and a length of $15.2 \mathrm{~m}(50 \mathrm{ft})$. A vane dike was added channelward of the spur dike, in the same alignment as the spur dike, with a 
spacing of $15.2 \mathrm{~m}(50 \mathrm{ft})$ between the spur and vane dike, with a length of $15.2 \mathrm{~m}$ $(50 \mathrm{ft})$ and an elevation of $3.0 \mathrm{mlt}$. Plan D is shown in Figure 17.

\section{Results}

\section{Current directions and velocities.}

Ebb Tide. With the $2.82 \mathrm{~km} / \mathrm{hr}(1.75 \mathrm{mph})$ condition (Plate 51), velocities about $152 \mathrm{~m}(500 \mathrm{ft})$ east of the bridge were up to $0.76 \mathrm{~m} / \mathrm{s}(2.5 \mathrm{fps}), 0.85 \mathrm{~m} / \mathrm{s}$ ( $2.8 \mathrm{fps})$ through the bridge, $0.91 \mathrm{~m} / \mathrm{s}(3.0 \mathrm{fps})$ off the end of the dike, and $0.98 \mathrm{~m} / \mathrm{s}$ (3.2 fps) in the entrance to the Bypass Channel. Currents stayed aligned with the GIWW until they passed the end of the dike, then diverted down the Bypass Channel. A slow clockwise eddy formed in the approach to the east lock. With the $4.03 \mathrm{~km} / \mathrm{hr}(2.5 \mathrm{mph})$ condition (Plate 52), velocities about $152 \mathrm{~m}$ $(500 \mathrm{ft})$ eastward of bridge are up to $0.91 \mathrm{~m} / \mathrm{s}(3.0 \mathrm{fps}), 1.04 \mathrm{~m} / \mathrm{s}(3.4 \mathrm{fps})$ through the bridge, $1.07 \mathrm{~m} / \mathrm{s}(3.5 \mathrm{fps})$ off the end of the dike, and about $1.25 \mathrm{~m} / \mathrm{s}$ (4.1 fps) in the entrance to the Bypass Channel. The currents remain aligned with the GIWW until passing the dike. A slow clockwise eddy formed in the East Lock approach.

The combination of dikes helped keep currents aligned with the GIWW longer during the ebb tide conditions, and with the gap between the dikes, helped reduce the angle at which the ebb tide flow left the GIWW and entered the Bypass Channel.

Flood tide. With the $2.82 \mathrm{~km} / \mathrm{hr}(1.75 \mathrm{mph})$ condition (Plate 53), velocities in the entrance to the Bypass Channel were up to $0.85 \mathrm{~m} / \mathrm{s}(2.8 \mathrm{fps}), 0.98 \mathrm{~m} / \mathrm{s}$ (3.2 fps) off the end of the dike, $0.85 \mathrm{~m} / \mathrm{s}(2.8 \mathrm{fps})$ through the bridge, and $0.85 \mathrm{~m} / \mathrm{s}(2.8 \mathrm{fps})$ about $152 \mathrm{~m}(500 \mathrm{ft})$ eastward of the bridge. Currents were aligned with the GIWW about $76 \mathrm{~m}(250 \mathrm{ft})$ westward of the bridge. With the $4.03 \mathrm{~km} / \mathrm{hr}(2.5 \mathrm{mph})$ condition (Plate 54), velocities in the entrance to the Bypass Channel are up to $1.22 \mathrm{~m} / \mathrm{s}(4.0 \mathrm{fps}), 1.13 \mathrm{~m} / \mathrm{s}(3.7 \mathrm{fps})$ off the end of the dike, $1.46 \mathrm{~m} / \mathrm{s}$ (4.8 fps) through the bridge, and up to $1.26 \mathrm{~m} / \mathrm{s}(4.2 \mathrm{fps})$ about 152 $\mathrm{m}(500 \mathrm{ft})$ eastward of the bridge. Currents were slightly stronger just westward of the bridge and through the bridge than they were with the base conditions.

\section{Navigation conditions.}

Ebb tide. With the $2.82 \mathrm{~km} / \mathrm{hr}(1.75 \mathrm{mph})$ condition and tows moving east to west (Plate 55), passage through the bridge and past the entrance to the Bypass Channel was not extremely difficult. By keeping the tow slightly north of the GIWW center line while coming through the bridge, the current effect from the Bypass Channel was minimal. With tows moving west to east (Plate 56), the best transits were made by keeping the tow northward of the GIWW center line after coming out of the East Lock. Controlling the set on the head of the tow was not difficult, but the stern was set southward as it came out into the currents. Passage through the bridge tended to be north of the GIWW center line, but there was no incidence of striking or rubbing along the north side bridge fenders. 


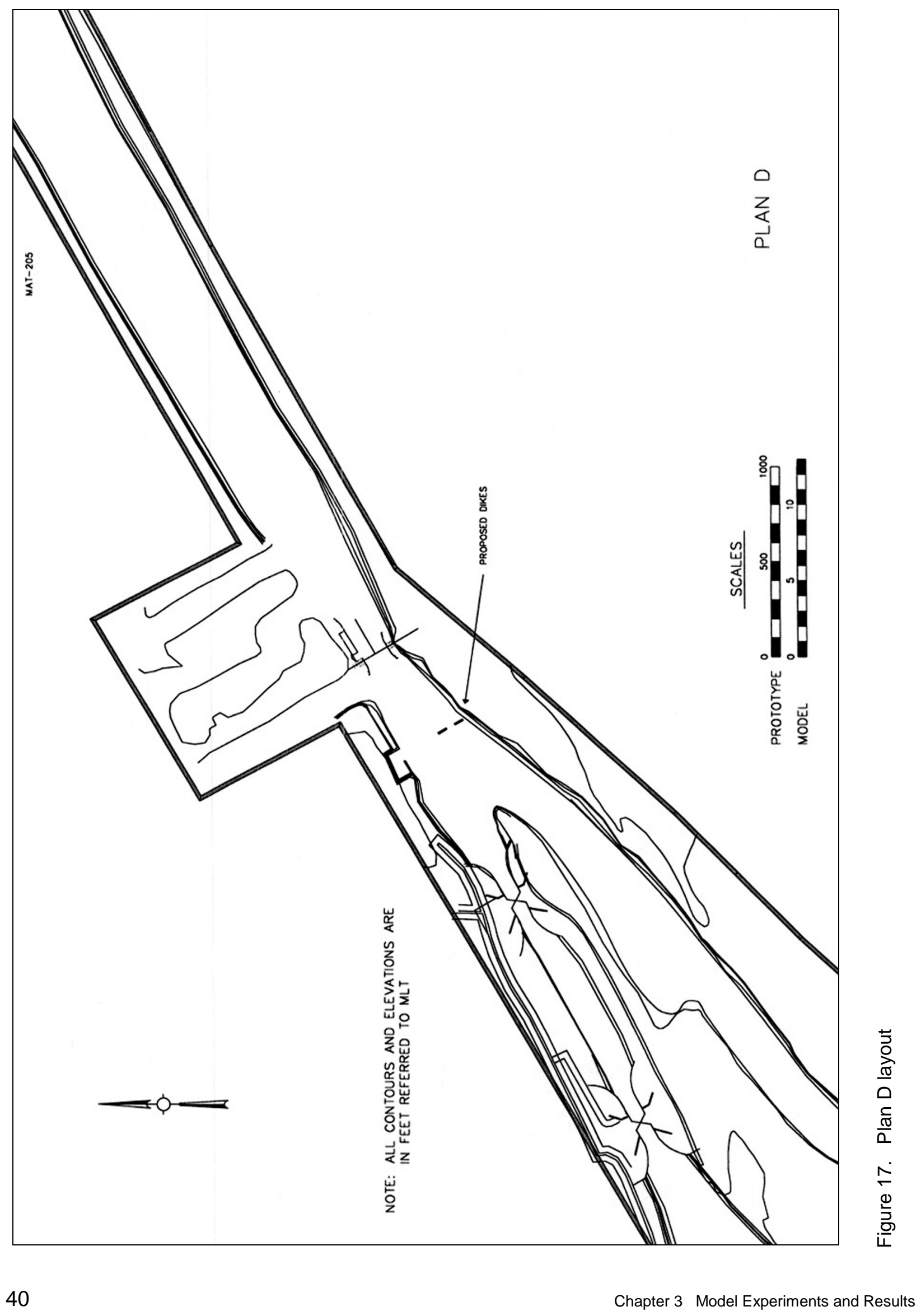


With the $4.03 \mathrm{~km} / \mathrm{hr}(2.5 \mathrm{mph})$ condition and tows moving east to west (Plate 57), the best transits were again made by coming through the bridge slightly north of the GIWW center line. The current flow around the end of the dike offset the pull of the current going westward into the Bypass Channel. The tows experienced some set on the stern of the tow as it passed westward of the dike, but not enough to present any significant difficulty. For tows moving west to east (Plate 58) the best approach was again to stay north of the GIWW center line. The head of the tow had little set induced by the flow, but the stern was pulled southward somewhat toward the Bypass Channel. This tended to make the tow pass close along the northern bridge fenders, but there were no incidences of touching the fender.

Flood tide. With the $2.82 \mathrm{~km} / \mathrm{hr}(1.75 \mathrm{mph})$ flow condition and tows moving east to west (Plate 59), the best approach was made by steering the tow slightly north of the GIWW center line through the bridge. There was little effect on the tow by either the dike or current flow from the Bypass Channel. With the tow moving west to east (Plate 60) the stern of the tow was set well north of the GIWW center line as it passed the entrance to the Bypass Channel, but the head of the tow could be held at a fairly constant distance from the center line. This allowed the tow to be brought through the bridge slightly north of the GIWW center line without much difficulty.

For the $4.03 \mathrm{~km} / \mathrm{hr}(2.5 \mathrm{mph})$ condition and tows moving east to west (Plate 61), the tow could be steered through the bridge near the GIWW center line, experience a slightly northward set as the tow passed the dike and entrance to the Bypass Channel, then get into alignment to enter the East Lock without significant difficulty. For the tows moving west to east (Plate 62), the tows were set slightly north as they came out of the East Lock, but were able to steer the head of the tow southward to come through the bridge near the GIWW center line without significant difficulty.

Overall, transits of tows with ebb tide conditions were slightly less difficult than with base conditions, and transits with flood tide conditions were similar to that of the base conditions. During evaluation of base conditions in the model, the ebb tide flows were determined to be more difficult than those with flood tide. The dike design attempted to improve navigation conditions during the ebb tide flows without degrading the conditions for flood tide flows. If the dike was built as a typical armored design, fendering or a dolphin might be considered for the channelward end to reduce the risk to a barge striking the dike. The use of a "soft dike" using sand-filled geotextile bags could be also considered as an alternative to a typical dike.

\section{Plan E - Removal of Southeast and Southwest Corners}

\section{Description}

Plan E consisted of the complete removal of the southwest and southeast corners of the Colorado/GIWW intersection (Figure 18). The bank lines were 


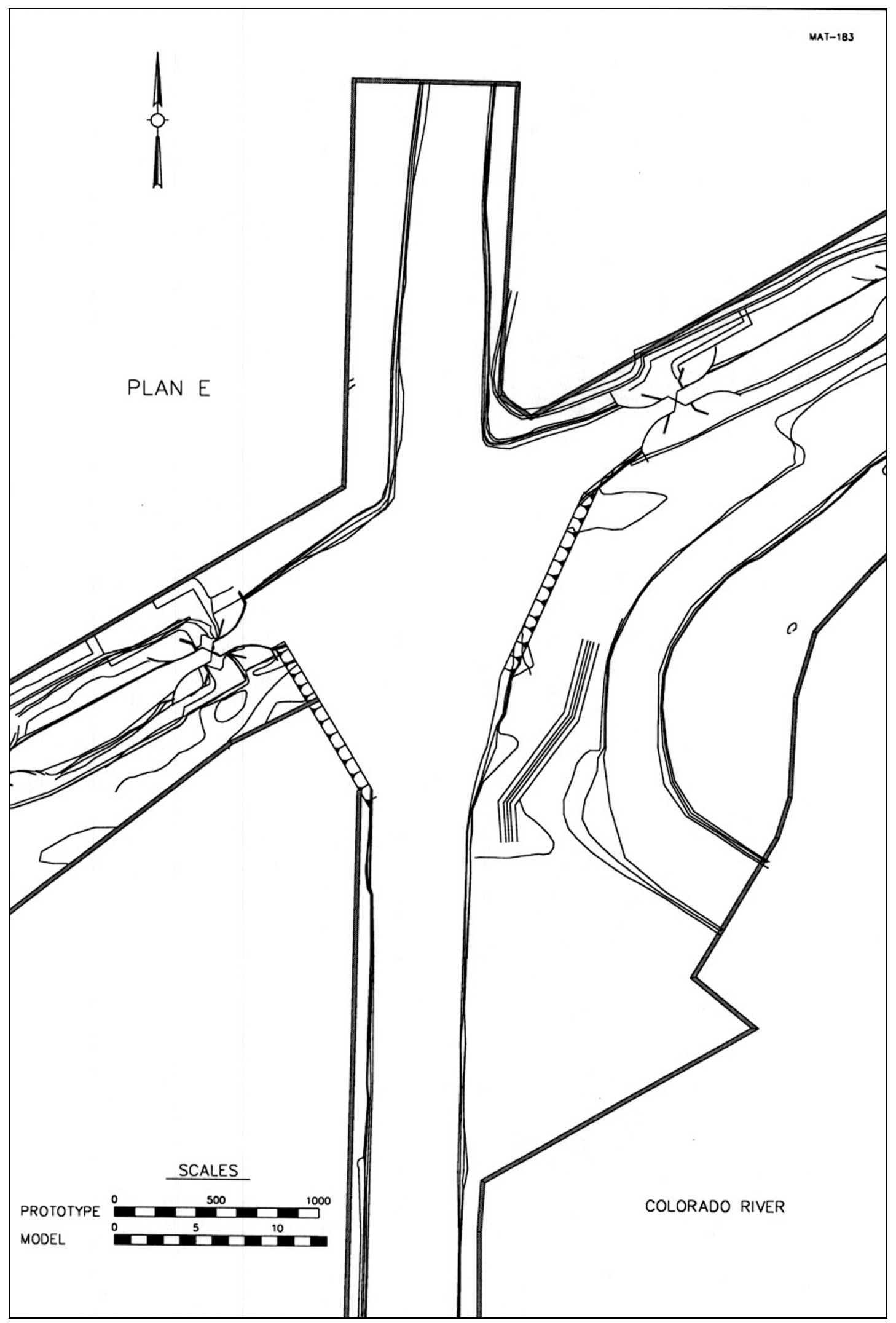

Figure 18. Plan E layout 
placed to an alignment provided by the Galveston District, cut to a slope of 1 on 3 , and the depth of the dredged channel was $3.66 \mathrm{~m} \mathrm{(-12} \mathrm{ft)} \mathrm{mlt.}$

\section{Results}

Current directions and velocities. With the $170 \mathrm{cu} \mathrm{m} / \mathrm{s}(6,000 \mathrm{cfs})$ flow condition (Plate 63) velocities along the left bank were up to $0.73 \mathrm{~m} / \mathrm{s}(2.4 \mathrm{fps})$, $0.52 \mathrm{~m} / \mathrm{s}(1.7 \mathrm{fps})$ near the center of the intersection, and up to $0.58 \mathrm{~m} / \mathrm{s}(1.9 \mathrm{fps})$ in the Diversion Channel. A large, slow counterclockwise eddy formed along the left descending side of the intersection from the northeast corner down to the southeast limit of the new southeast bank line. A slow clockwise eddy formed in the West Lock approach. With the $283 \mathrm{cu} \mathrm{m} / \mathrm{s}(10,000 \mathrm{cfs})$ flow condition (Plate 64), velocities along the left descending bank line of the Colorado were up to $0.91 \mathrm{~m} / \mathrm{s}(3.0 \mathrm{fps}), 0.73 \mathrm{~m} / \mathrm{s}(2.4 \mathrm{fps})$ in the center of the intersection, and generally $0.61 \mathrm{~m} / \mathrm{s}(2.0 \mathrm{fps})$ and greater in the Diversion Channel. A large counterclockwise eddy formed in the East Lock approach that extended from almost the western ends of the East Lock wing walls to the most downstream point of the bank line cut along the left descending bank of the Diversion Channel. A similar, clockwise eddy was formed in the West Lock approach with almost the same extents. Between these eddies, the flow in the intersection appeared almost compressed into a somewhat narrow band of higher currents.

Navigation conditions. Tows moving east to west with the $283 \mathrm{cu} \mathrm{m} / \mathrm{s}$ (10,000 cfs) flow condition (Plate 65) had somewhat more difficulty in making the transit as compared with the base conditions. The set on the tow was more pronounced as the tow entered into the intersection and the tow could not get out of the current before the head of the tow reached the West Lock wing walls. For the west to east tows using the $283 \mathrm{cu} \mathrm{m} / \mathrm{s}(10,000 \mathrm{cfs}$ ) flow condition (Plate 66), the crossings were also more difficult than with the base conditions. The tow could not be turned north to get an attack angle into the current from the Colorado. The tow was set well down into the intersection and tended to have the head of the tow slightly north of the GIWW center line as the tow approached the East Lock wing walls. The stern of the tow could not be steered upward into the current, even as the head of the tow was almost at the wing walls. This tended to cause the head of the tow to strike the north wing wall. To expedite the study, evaluation with the $170 \mathrm{cu} \mathrm{m} / \mathrm{s}(6,000 \mathrm{cfs})$ flow condition was not performed since navigation conditions for the more critical $283 \mathrm{cu} \mathrm{m} / \mathrm{s}(10,000 \mathrm{cfs})$ flow condition were not improved.

\section{Plan F - Relocation of the Bypass Channel}

\section{Description}

During the study, the State of Texas Highway Department was developing plans for construction of a new bridge to replace the floating pontoon bridge currently in use. An idea was put forward that if a new bridge was to be constructed, the possibility of rerouting the Bypass Channel to join the GIWW eastward of the present bridge could be considered. How far this confluence 
should be from the bridge to provide adequate navigation conditions was to be determined by the model. The as-built model for the GIWW did not provide adequate length eastward of Matagorda Bridge for this determination and due to the placement of the model in the shelter, additional length could not be added. To obtain this information, an existing sandbed flume was modified to replicate the GIWW from approximately the East Lock to 2,440 m (8,000 ft) eastward of the lock at a 1:70 scale. The channel cross sections of the GIWW at several locations along the GIWW were compared with each other and determined to be fairly symmetric and uniform in width. A typical, symmetric cross section was used to make a template to mold the GIWW channel to the same scale as the fixed-bed model. A typical section was taken about $305 \mathrm{~m}(1,000 \mathrm{ft})$ eastward of the bridge and represented the cross section of the Bypass Channel used to mold the Bypass Channel. The Bypass Channel /GIWW confluence was molded to replicate the existing confluence. The Bypass Channel was placed at approximately the midlength of the molded GIWW channel. A series of marking pins was placed in alignments along with spacings to represent the bridge pilings and fenders that make up the existing pontoon bridge. The distance that these markings pins were placed from the confluence was varied from one tow length $291 \mathrm{~m}$ (955 ft) up to three tow lengths $873 \mathrm{~m}(2,865 \mathrm{ft})$ to represent from one to three tow lengths from the bridge. The model tow was operated and recorded using a video camera mounted just westward of the bridge sites. The $4.03 \mathrm{~km} / \mathrm{hr}$ $(2.5 \mathrm{mph})[116 \mathrm{~m} / \mathrm{s}$ (3.8 fps)] velocity condition was used for both the ebb and flood tide condition as determined by the highest velocities measured in the Bypass Channel. A point gage was set up over the model and adjusted to allow the monitoring and control of the water-surface elevation. This model site was not equipped to allow collection of current direction and velocity data or collection of water-surface profiles.

\section{Results}

\section{Navigation conditions.}

Ebb Tide, tows moving east to west. With the bridge at three tow lengths from the Bypass Channel (Figure 19), the tow was set well toward the Bypass Channel as it passed, but the tow recovered and was in alignment to pass through the bridge approximately two tow lengths eastward of the bridge. With the bridge at two tow lengths (Figure 20), again the tow had a strong set toward the Bypass Channel but was able to come into alignment with the bridge about one tow length eastward of the bridge. With the bridge at one tow length (Figure 21) the tow was set toward the Bypass Channel, but the head of the tow was almost at the bridge fenders before the stern of the tow passed clear of the current set going out the Bypass Channel. Although the bridge fender was not struck, the maneuvering to avoid colliding was difficult.

Ebb Tide, tows moving west to east. With the bridge at three tow lengths from the Bypass Channel (Figure 22) the tow passed through the bridge with no difficulty and had plenty of room to prepare for the set toward the Bypass Channel. The set on the stern of the tow was not extremely difficult to control and passage eastward of the Bypass Channel was not difficult. With the bridge at 


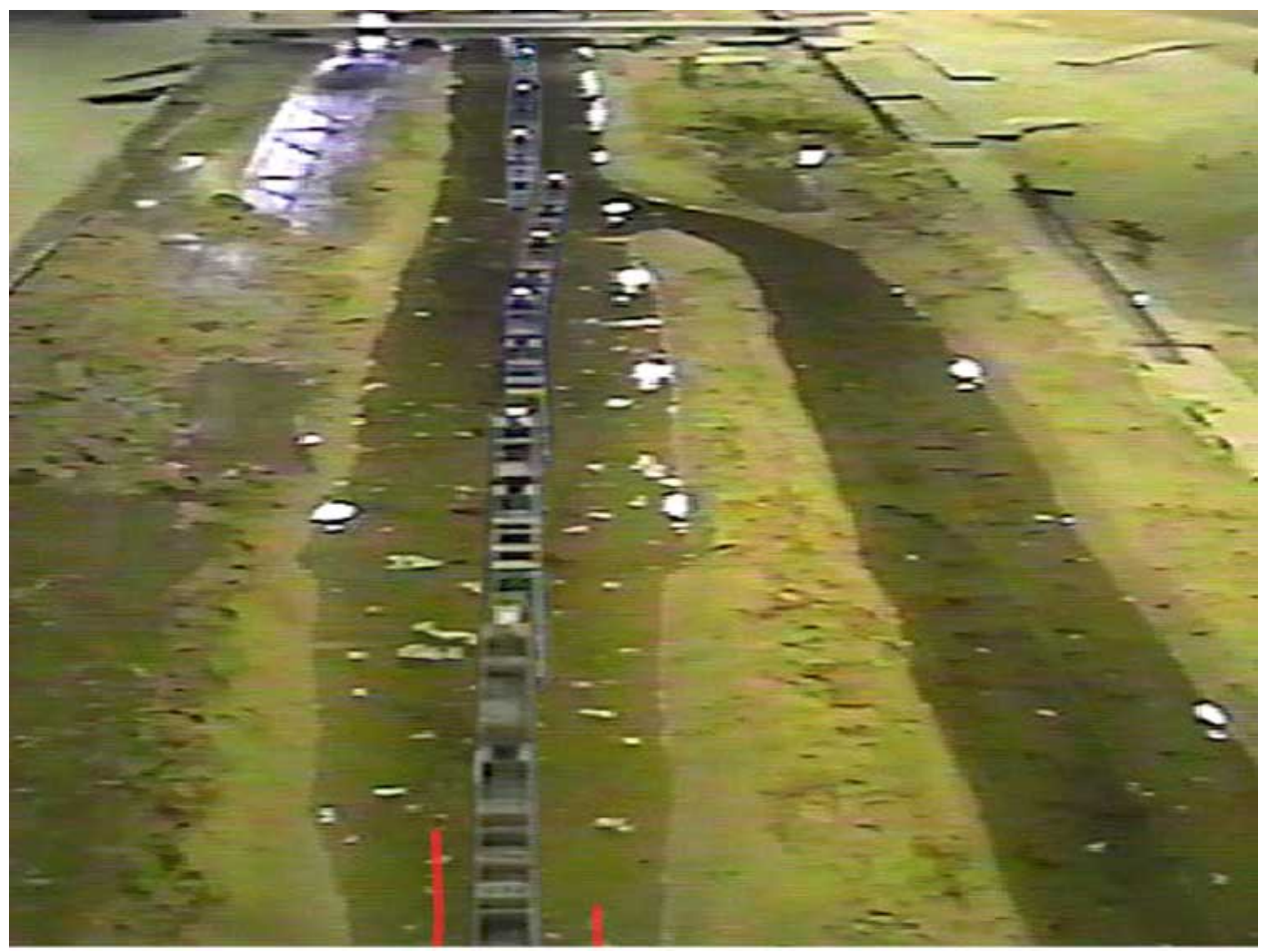

Figure 19. Flow east to west with bridge three tow lengths from confluence, tow moving east to west

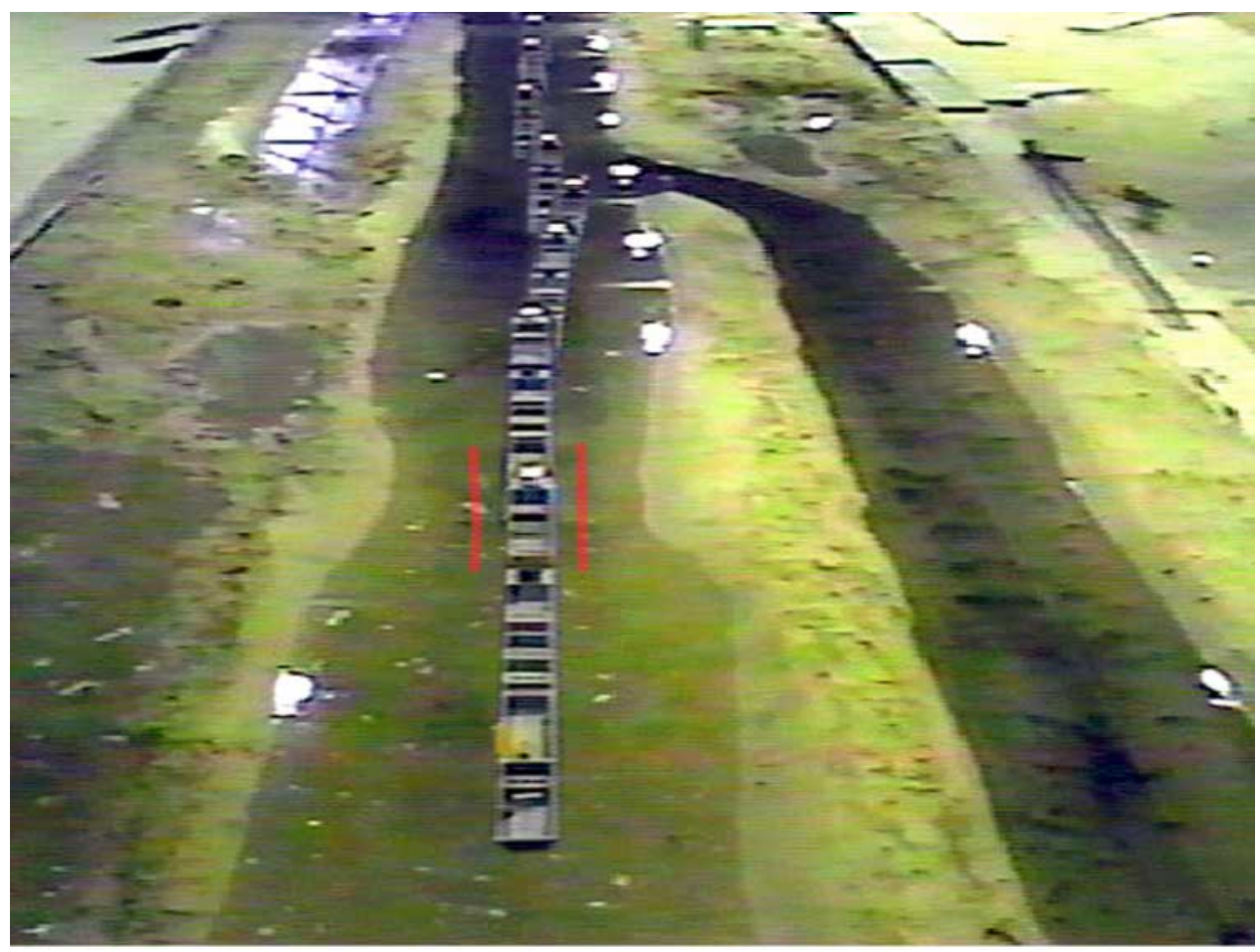

Figure 20. Flow east to west with bridge two tow lengths from confluence, tow moving east to west 


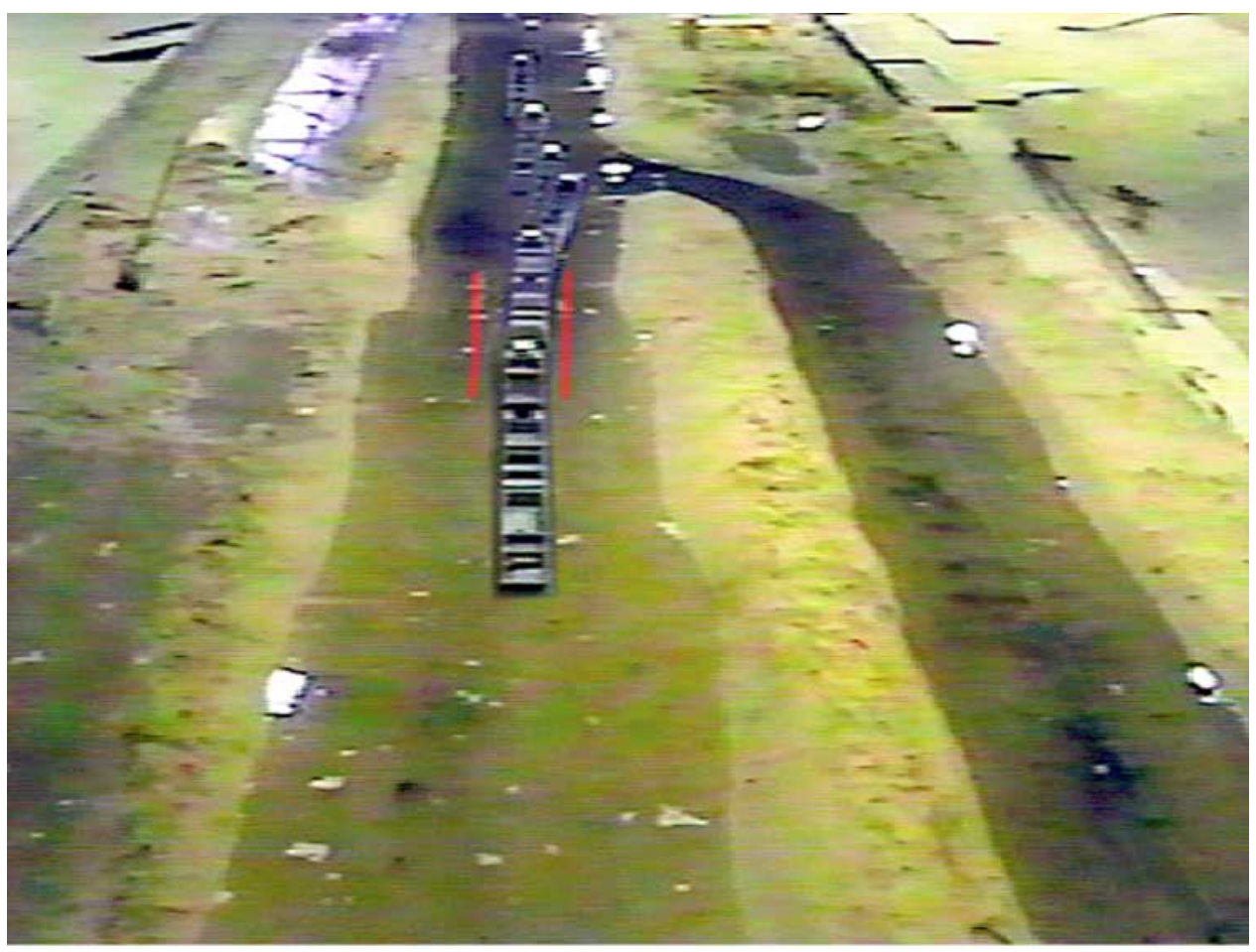

Figure 21. Flow east to west with bridge one tow length from confluence, tow moving east to west

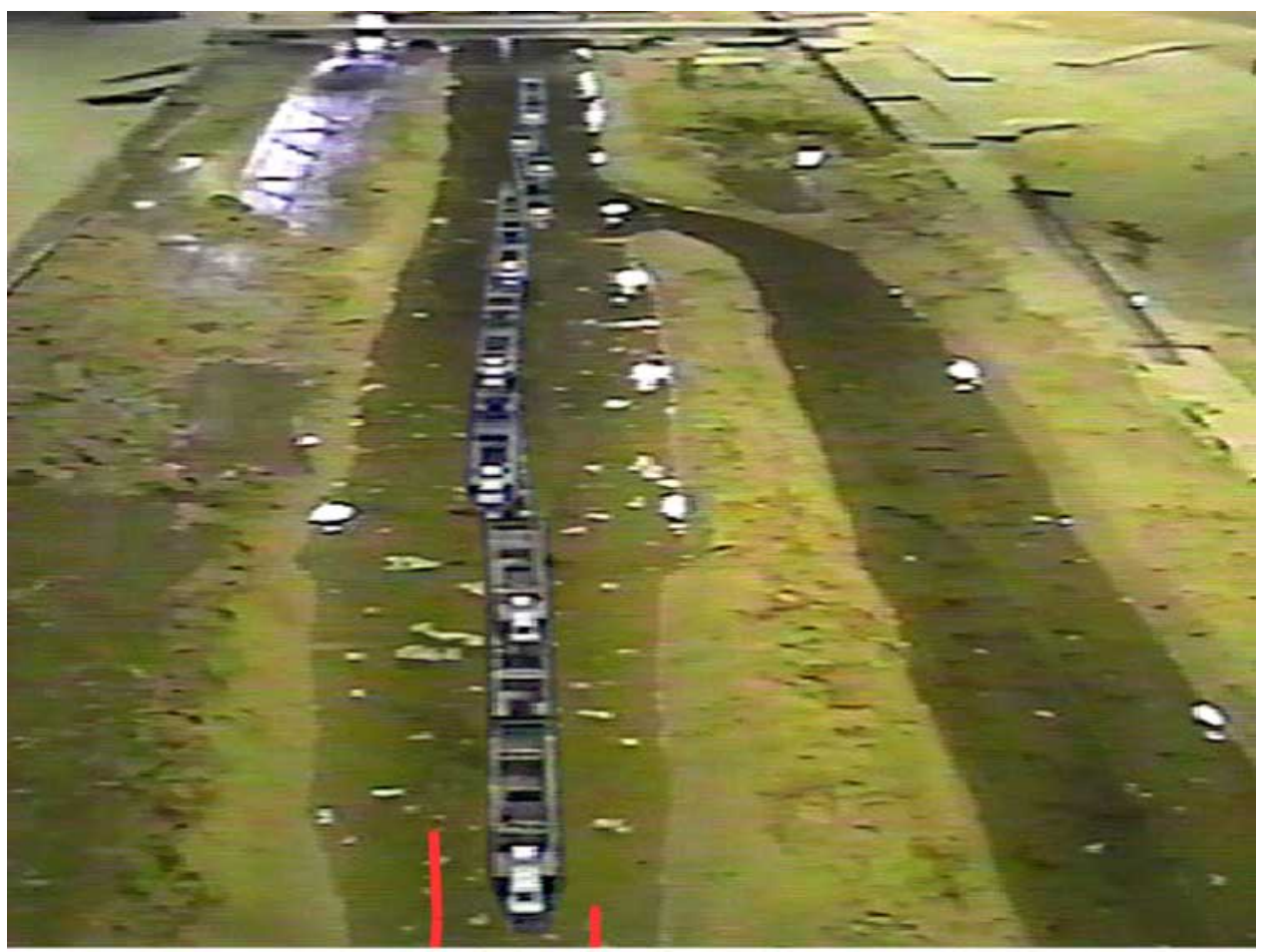

Figure 22. Flow east to west with bridge three tow lengths from confluence, tow moving west to east 
two tow lengths (Figure 23), the tow still had sufficient room to come through the bridge, then maneuver in preparation of the anticipated set into the Bypass Channel. With the bridge at one tow length from the Bypass Channel (Figure 24), the tow could pass safely through the bridge, but as the stern cleared the bridge fenders, the head of the tow was subjected to set from current passing down the Bypass Channel. Holding the head of the tow, then the stern of the tow against the current set was not dangerously difficult, but was more difficult than with the bridge being two tow lengths from the Bypass Channel.

Flood Tide, tows moving east to west. With the bridge at three tow lengths from the Bypass Channel (Figure 25) the tow was set northward by the flood flow from the Bypass Channel, but there was sufficient distance to the bridge that the tow came into alignment at almost 2.5 tow lengths from the bridge.

Navigating past the current set of the Bypass Channel was performed with only moderate difficulty. With the bridge at two tow lengths (Figure 26), the set on the tow was not very difficult to manage and the tow came into alignment with the bridge by approximately 1.5 tow lengths eastward of the bridge. With the bridge at one tow length from the bridge (Figure 27) the set from the flood current was not difficult to control, but the head of the tow was only about onehalf tow length from the bridge before the tow was completely in alignment to pass the bridge.

Flood Tide, tows moving west to east. With the bridge at three tow lengths from the Bypass Channel (Figure 28) the tow passed through the bridge and had a large amount of room to prepare for the strong set from the flood current. The tow was pushed well northward while passing the Bypass Channel, but maintaining control of the tow and managing the set was not overly difficult. With the bridge at two tow lengths (Figure 29) the tow had sufficient room to clear the bridge and prepare for the current set from the Bypass Channel. With the bridge at one tow length from the Bypass Channel (Figure 30) the head of the tow was starting to be set northward as the stern of the tow was just clearing the bridge. The transits were made successfully but with greater difficulty than with the bridge being at two tow lengths or greater from the Bypass Channel.

\section{Plan G - Removal of South Gate of West Lock}

\section{Description}

Plan G (Figure 31) removed the south miter gate and wing wall from the east end of the West Lock, leaving the north gate and wing wall intact. This plan would be similar to the original design from the late 1940s of only single flood control gates in the GIWW on both the east and west side of the Colorado River. At that time, tows could not push through the flood gate against the current and a second set of gates were installed on either side of the Colorado closer to the intersection, forming the now existing East and West Lock. The bottom width of the channel was $38.1 \mathrm{~m}(125 \mathrm{ft})$ and an elevation of $-15 \mathrm{mlt}$ and the left bank line from the southwest point of the Colorado/GIWW intersection to the west gate of the West Lock was cut on a 1 on 3 slope from -15 mlt to top bank. This made the channel through the West Lock asymmetrical to the center line of the GIWW, but 


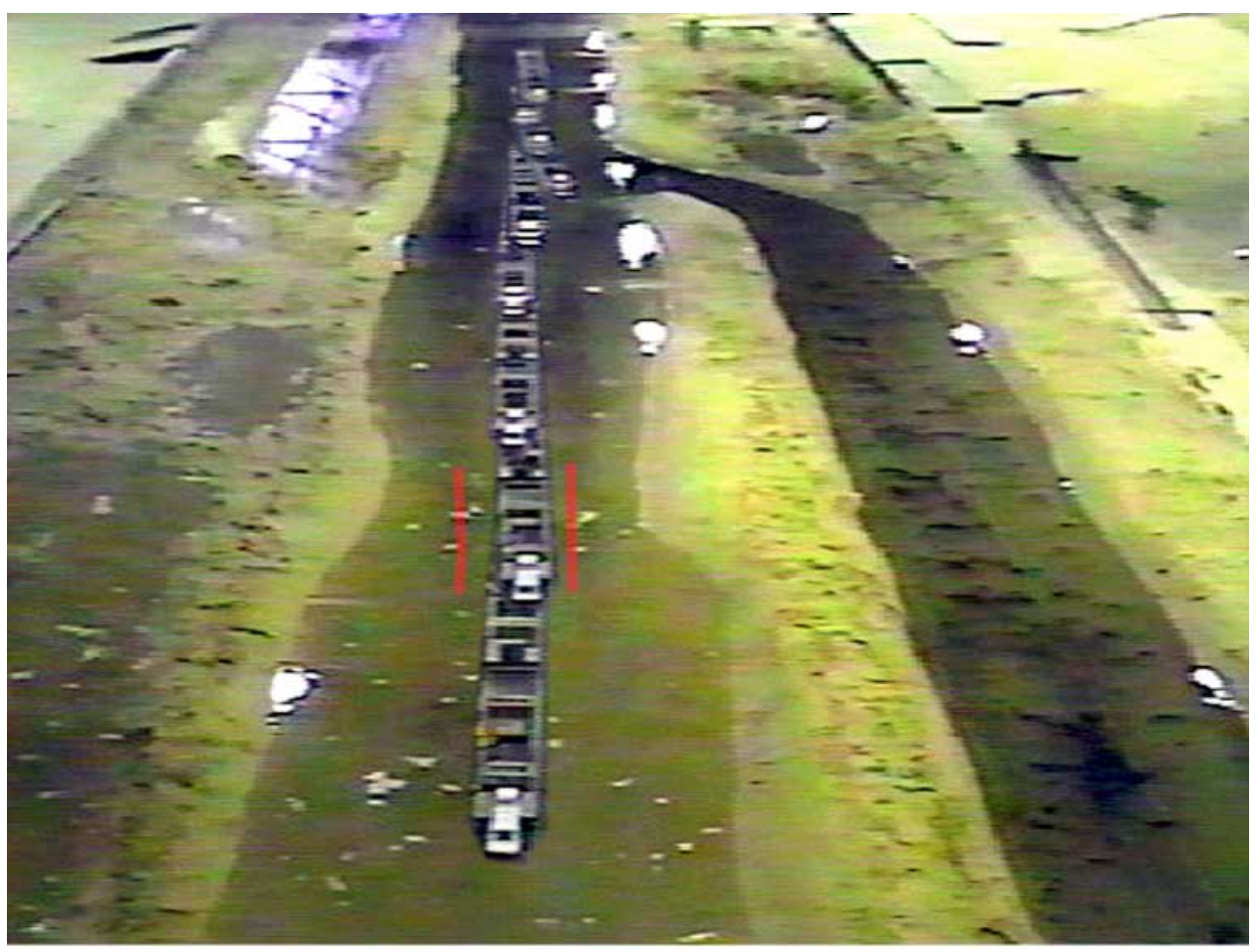

Figure 23. Flow east to west with bridge two tow lengths from confluence, tow moving west to east

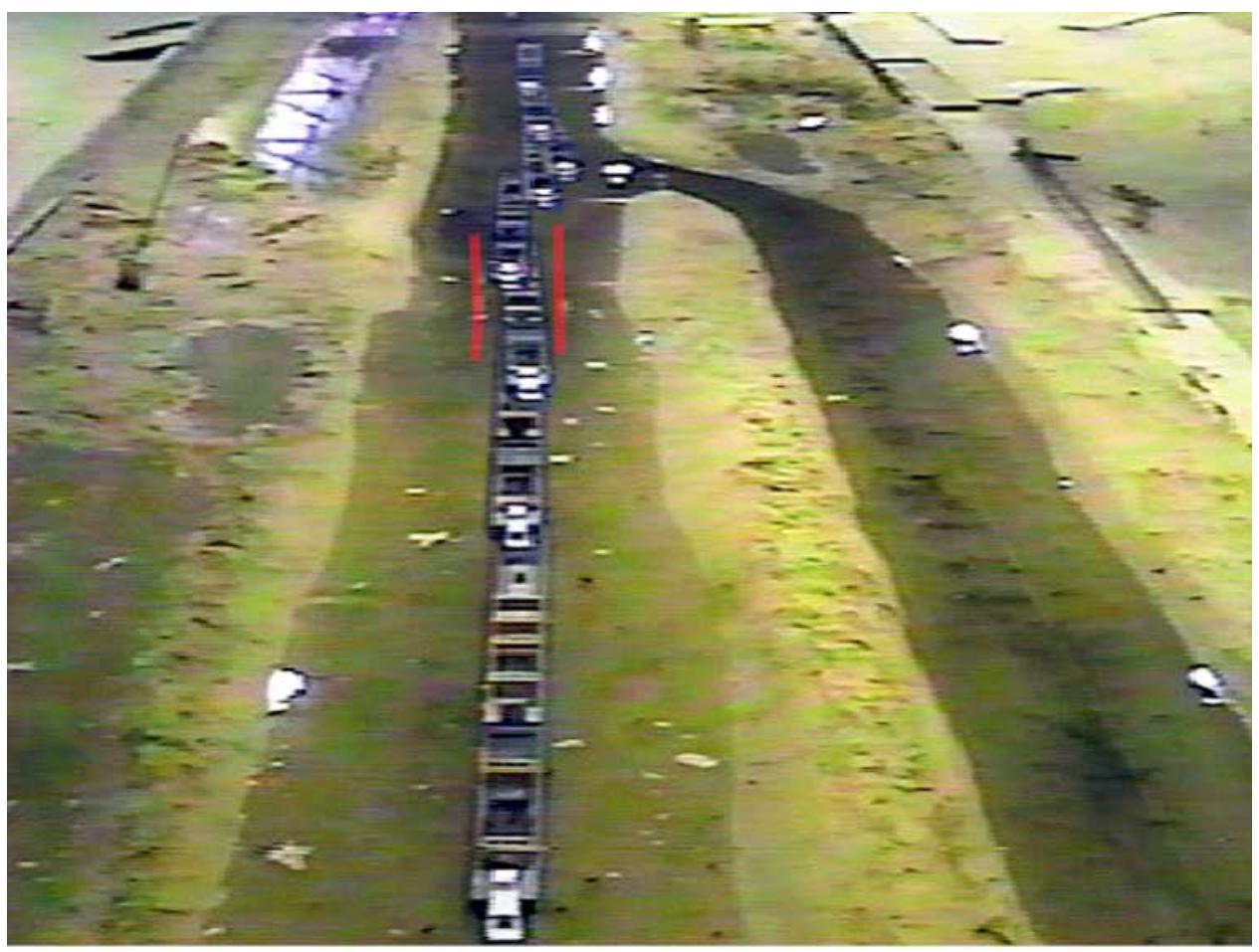

Figure 24. Flow east to west with bridge one tow length from confluence, tow moving west to east 


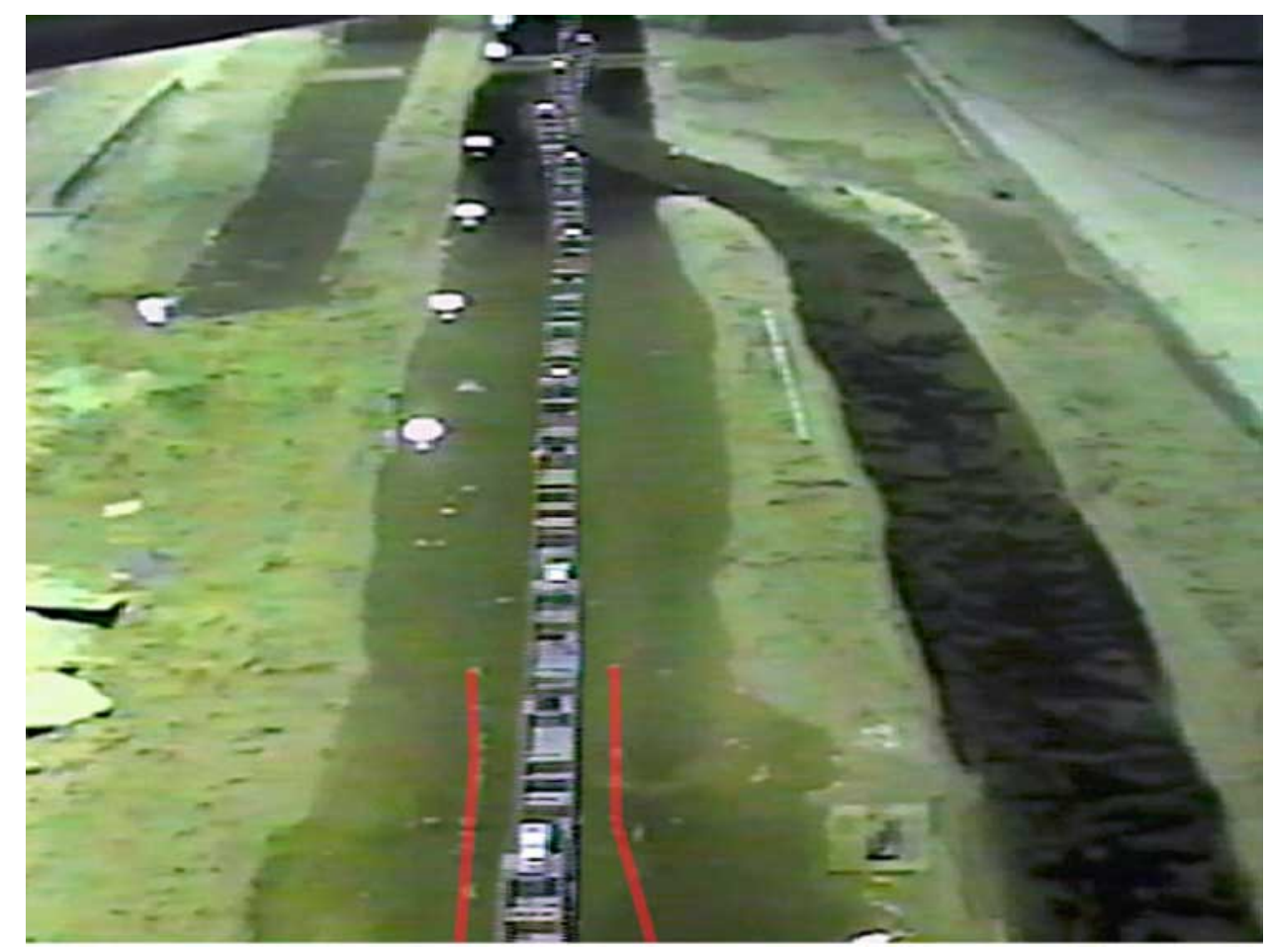

Figure 25. Flow west to east with bridge three tow lengths from confluence, tow moving east to west

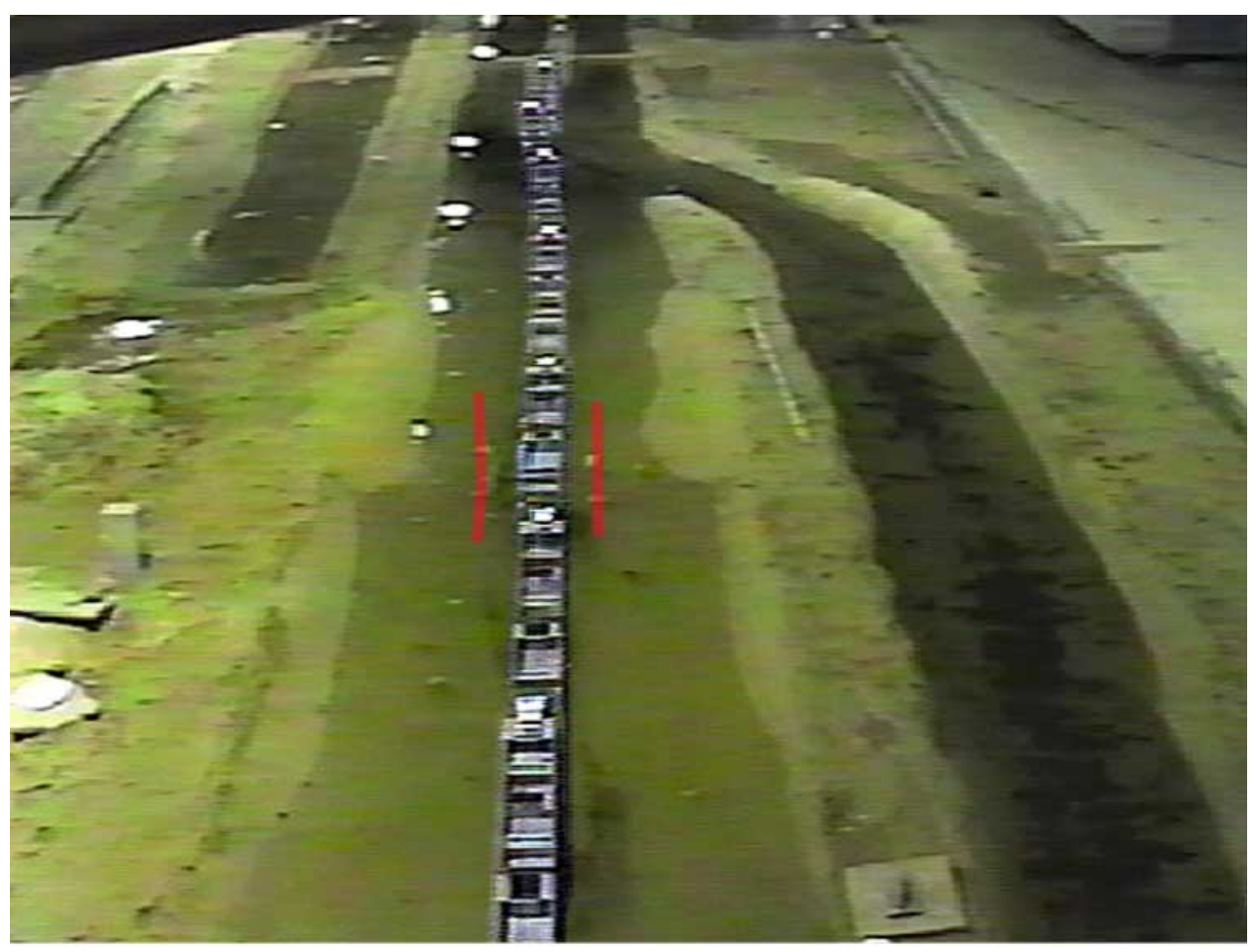

Figure 26. Flow west to east with bridge two tow lengths from confluence, tow moving east to west 


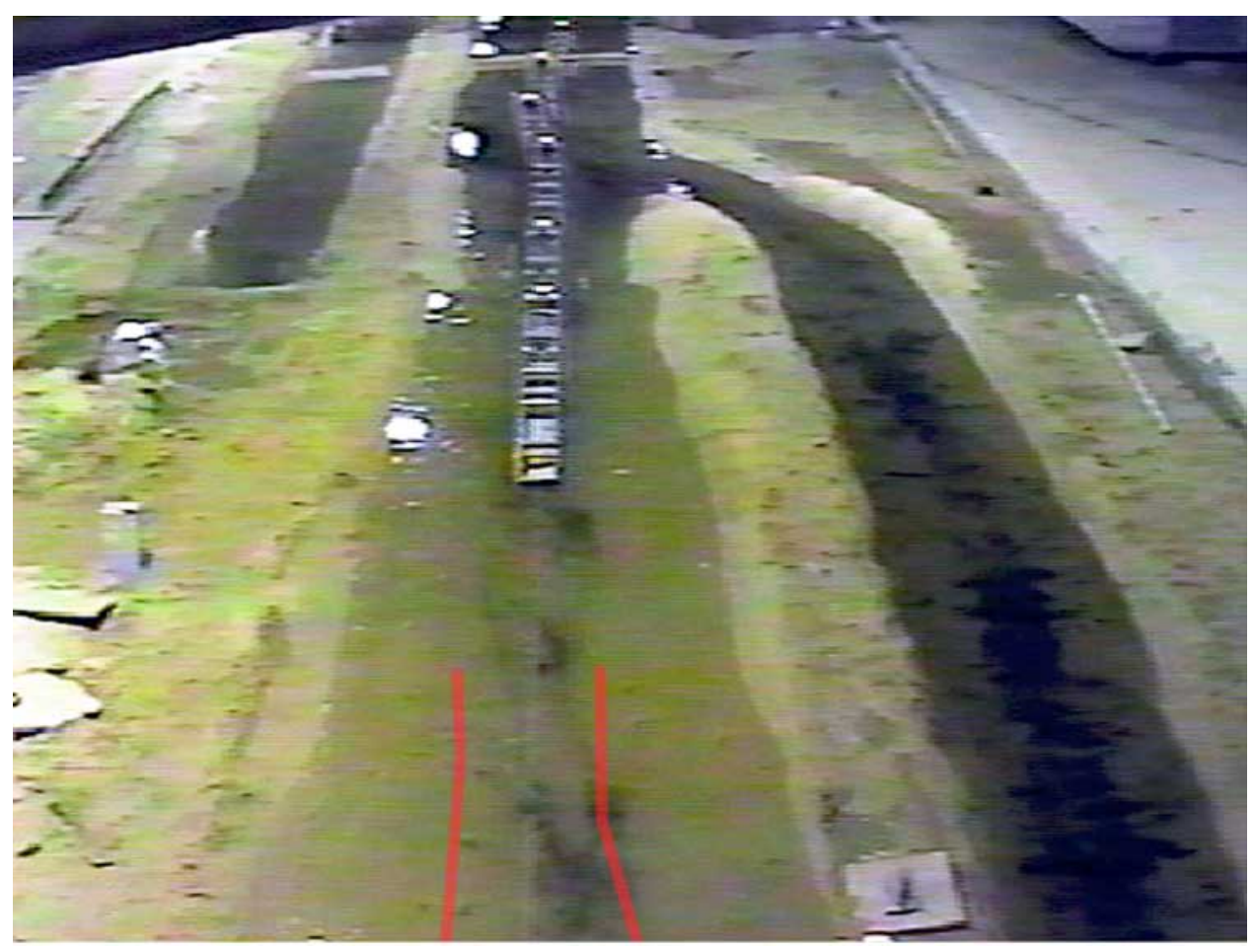

Figure 27. Flow west to east with bridge one tow length from confluence, tow moving east to west

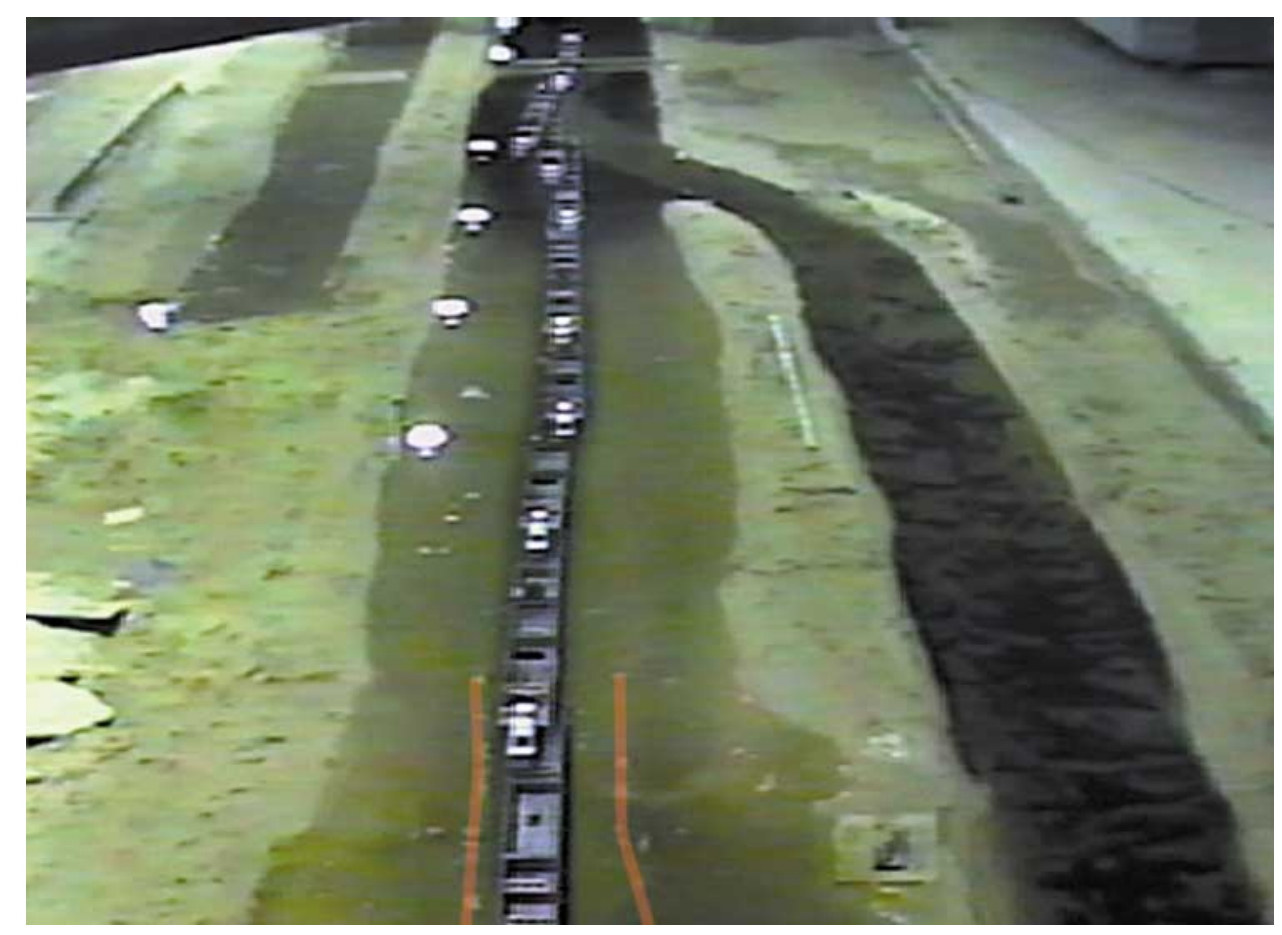

Figure 28. Flow east to west with bridge three tow lengths from confluence, tow moving west to east 


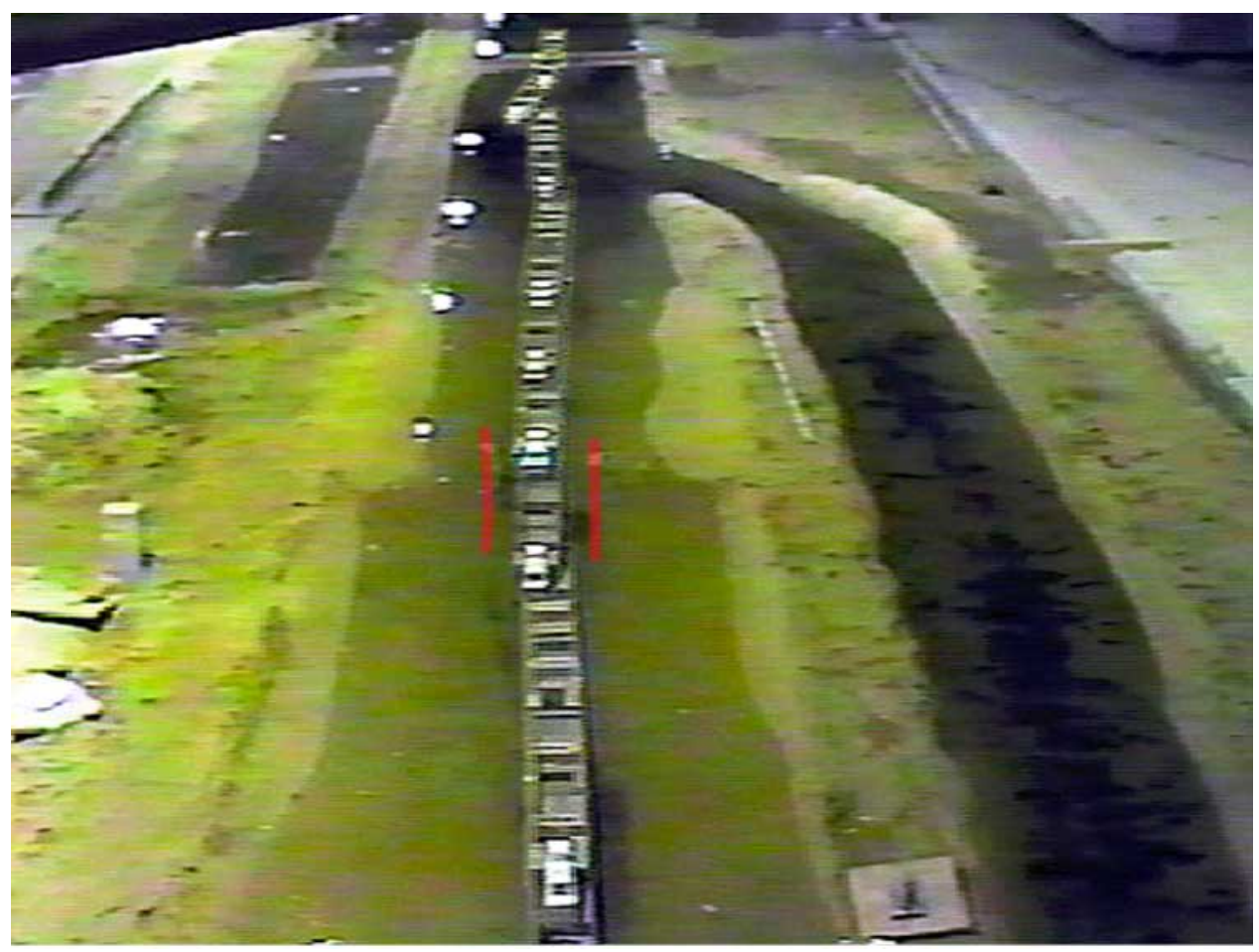

Figure 29. Flow east to west with bridge two tow lengths from confluence, tow moving west to east

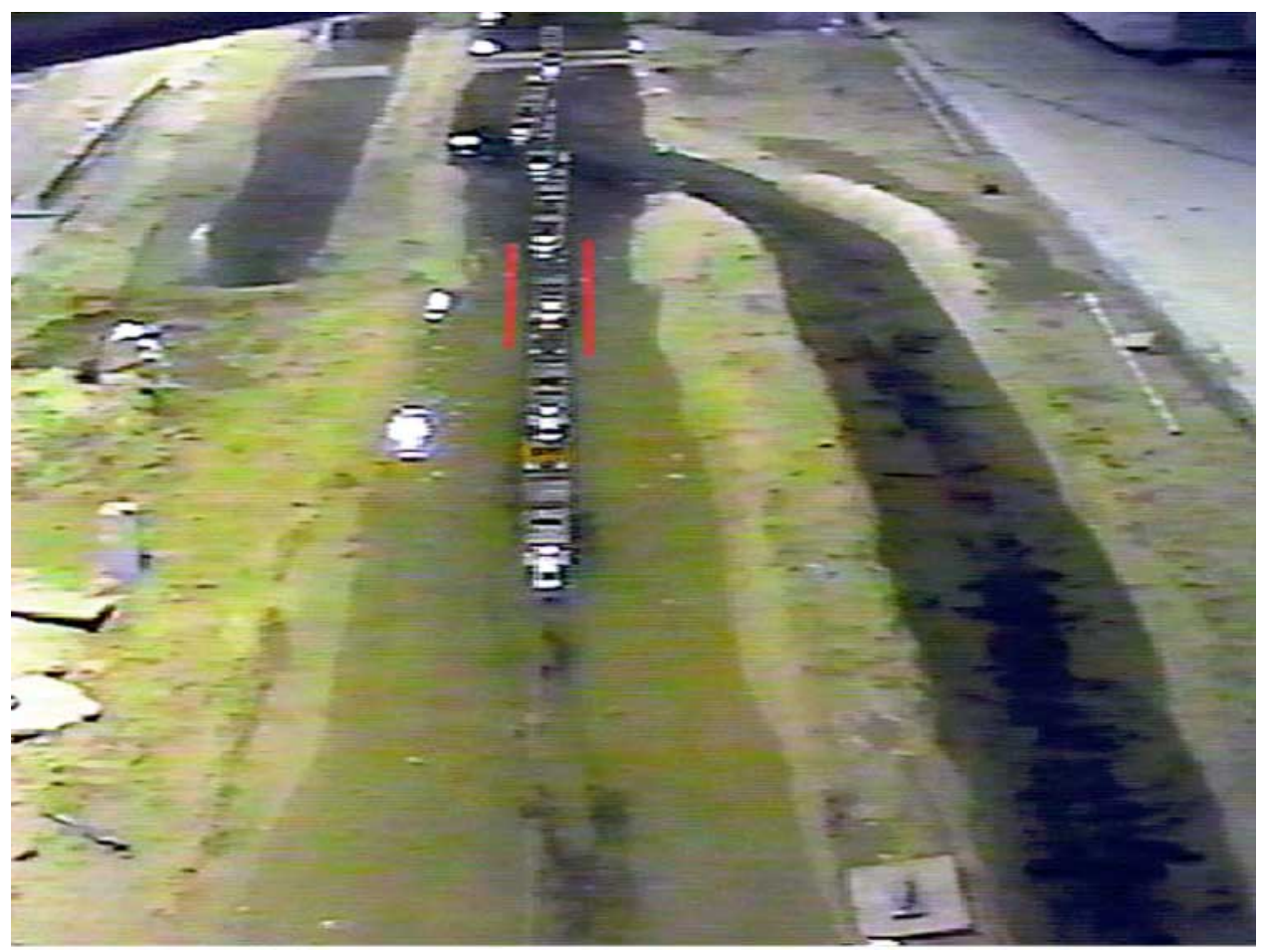

Figure 30. Flow east to west with bridge one tow length from confluence, tow moving west to east 


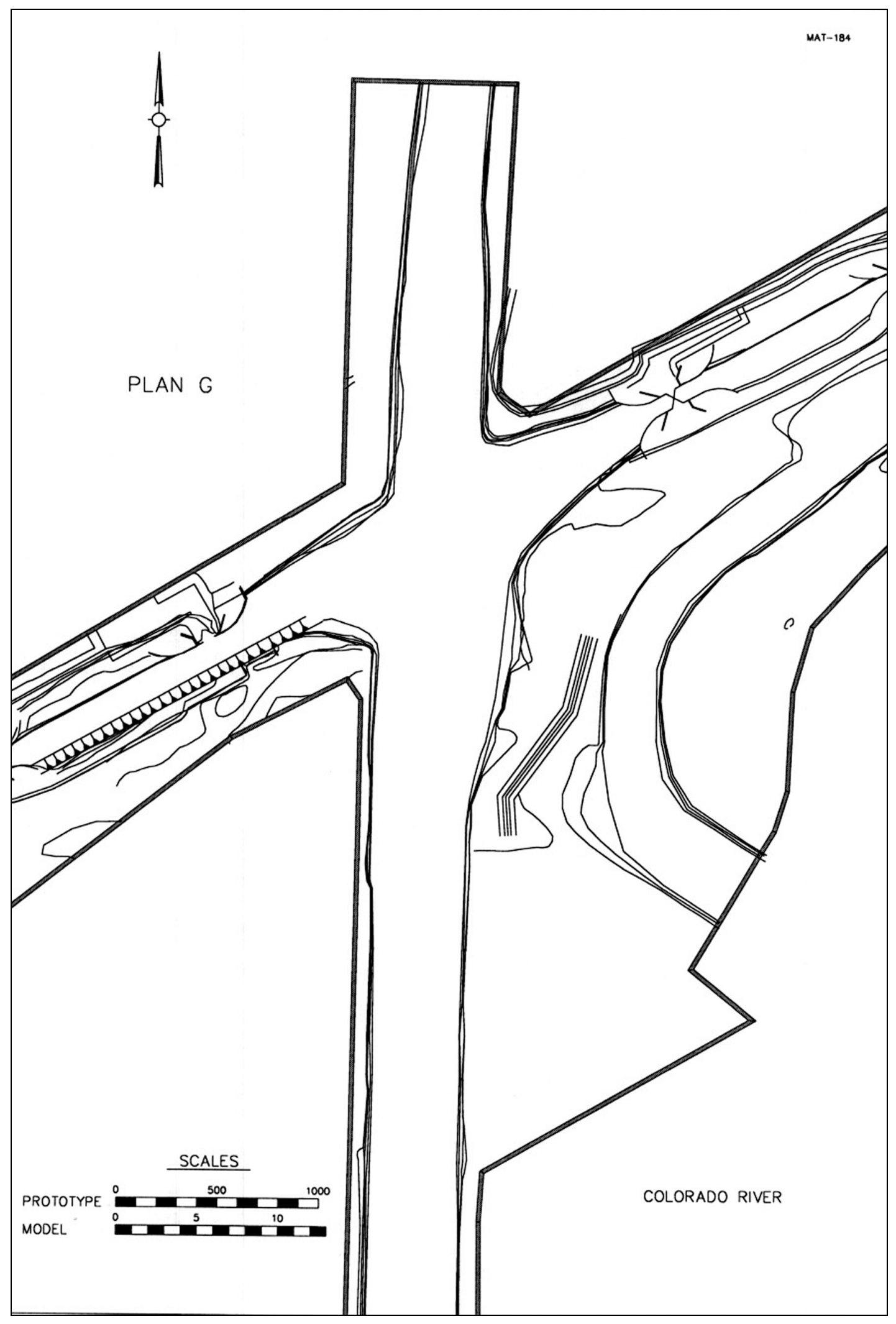

Figure 31. Plan G layout 
it reduces construction costs considerably. This plan could not be examined to determine how tows would be affected by flow coming through the remaining gate because of model limitations and lack of shelter space.

\section{Results}

Current directions and velocities. For the $170 \mathrm{cu} \mathrm{m} / \mathrm{s}(6,000 \mathrm{cfs})$ flow condition (Plate 67) velocities along the left bank were up to $0.58 \mathrm{~m} / \mathrm{s}(1.9 \mathrm{fps})$, $0.46 \mathrm{~m} / \mathrm{s}(1.5 \mathrm{fps})$ near the center of the intersection, and 0.67 to $0.73 \mathrm{~m} / \mathrm{s}(2.2$ to $2.4 \mathrm{fps}$ ) near the entrance to the Diversion Channel. There were almost no signs of an eddy in the East Lock approach, and only a slow clockwise eddy in the West Lock approach. For the $283 \mathrm{cu} \mathrm{m} / \mathrm{s}$ (10,000 cfs) flow condition (Plate 68), velocities were up to $0.95 \mathrm{~m} / \mathrm{s}(3.1 \mathrm{fps})$ along the left descending bank line of the Colorado, $0.64 \mathrm{~m} / \mathrm{s}(2.1 \mathrm{fps})$ near the center of the intersection, and $0.79 \mathrm{~m} / \mathrm{s}$ ( $2.6 \mathrm{fps}$ ) near the entrance to the Diversion Channel. A small counterclockwise eddy formed adjacent to the straight-line currents in the East Lock approach and was driving a larger, clockwise eddy between it and the East Lock. A large, slow clockwise eddy formed in the West Lock approach.

Navigation conditions. For the $283 \mathrm{cu} \mathrm{m} / \mathrm{s}(10,000 \mathrm{cfs})$ flow conditions and tows moving east to west (Plate 69), the tows still experienced the strong set in the intersection, but had more maneuvering room in the West Lock approach. Although there was more room, the tows still did not get the stern completely out of the current until the head of the tow was near the north wing wall. If the head of the tow was slightly too far north of the GIWW center line when the head stopped setting southward, the tow still had a tendency to hit the north wingwall. The extra channel width that was gained by removal of the south miter gate cannot be fully taken advantage of because the tow tended to ground on the southwest corner if the head of the tow was south of GIWW center line. For tows moving west to east (Plate 70), the tow had maneuvering room to angle the tow into the current before the head of the tow reached the current. This allowed the head of the tow to start out north of the GIWW center line and gradually set down into alignment with the East Lock. By having room for the head of the tow to set, the stern did not have to be steered as hard to the left to hold the head of the tow up in the current. The stern did not set as far as with the base conditions and the tow was easier to get into alignment to enter the East Lock. To expedite the study, evaluation with the $170 \mathrm{cu} \mathrm{m} / \mathrm{s}(6,000 \mathrm{cfs})$ flow condition was not performed since navigation conditions for the more critical $283 \mathrm{cu} \mathrm{m} / \mathrm{s}$ $(10,000 \mathrm{cfs})$ flow condition were not sufficiently improved.

\section{Plan G-1 - Removal of Both Eastern Gates, West Lock}

\section{Description}

Plan G-1 (Figure 32) removed both the north and south gates from the east end of the West Lock, removing the gates, lock walls, and wing walls, creating a 


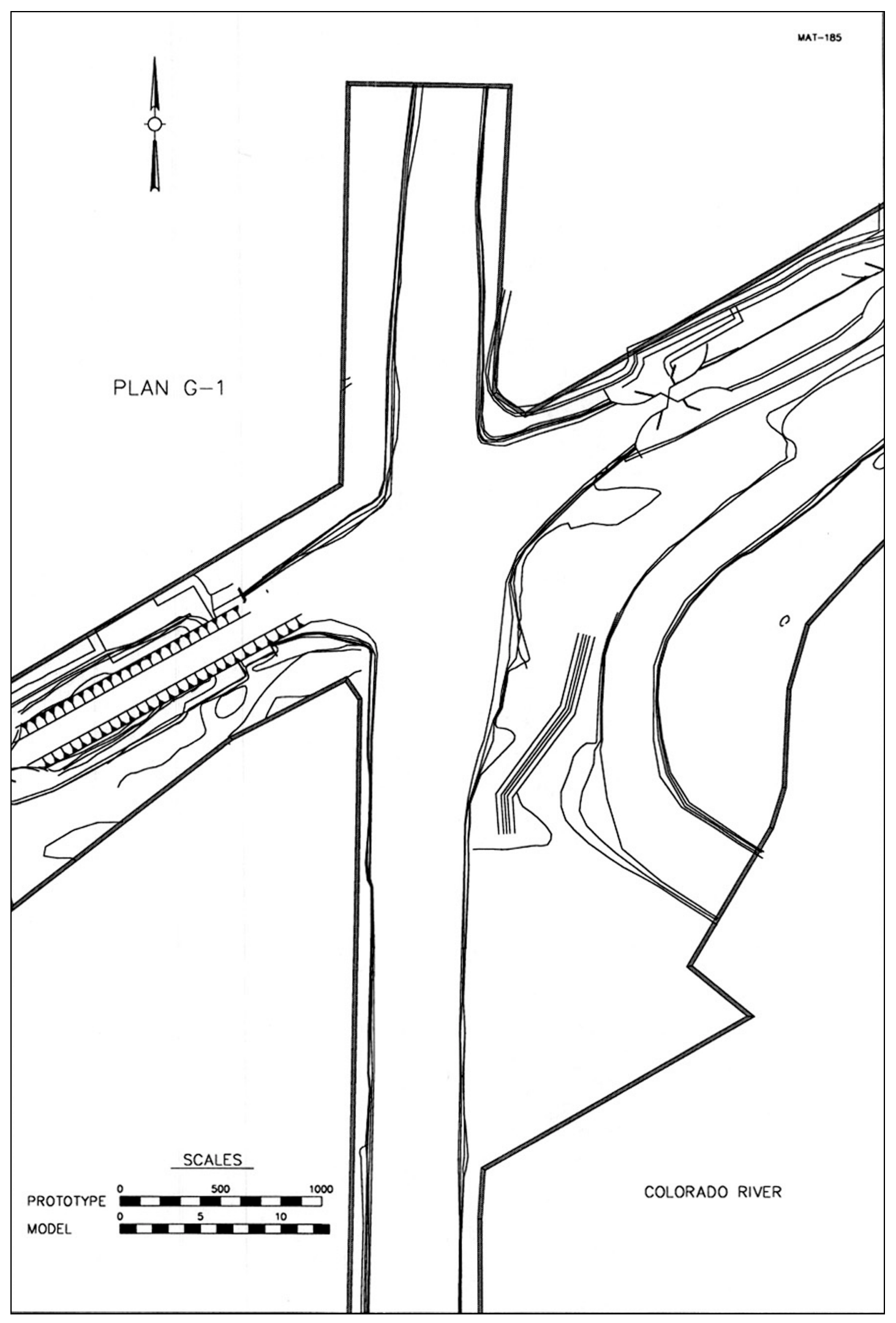

Figure 32. Plan G-2 layout 
symmetrical channel about the GIWW center line. The bottom width of the channel was $38.1 \mathrm{~m}(125 \mathrm{ft})$, centered on the GIWW center line, with an elevation of $-15 \mathrm{mlt}$ and the left and right bank lines from the northwest and southwest points of the Colorado/GIWW intersection to the west gate of the West Lock was cut on a 1 on 3 slope from -15 mlt to top bank. As with Plan G, no evaluation of how the tow might be affected by flow through the remaining set of miter gates could be performed.

\section{Results}

Current directions and velocities. With the $170 \mathrm{cu} \mathrm{m} / \mathrm{s}(6,000 \mathrm{cfs})$ flow condition (Plate 71), velocities along the left bank were up to $0.61 \mathrm{~m} / \mathrm{s}(2.0 \mathrm{fps})$, $0.52 \mathrm{~m} / \mathrm{s}(1.7 \mathrm{fps})$ near the center of the intersection, and up to $0.76 \mathrm{~m} / \mathrm{s}(2.5 \mathrm{fps})$ near the entrance to the Diversion Channel. There was only a very small counterclockwise eddy in the East Lock approach and no clearly discernable eddy in the West Lock approach. The $283 \mathrm{cu} \mathrm{m} / \mathrm{s}$ (10,000 cfs) flow condition (Plate 72) indicated velocities along the left descending bank of the Colorado to be up to $1.01 \mathrm{~m} / \mathrm{s}(3.3 \mathrm{fps}), 0.76 \mathrm{~m} / \mathrm{s}(2.5 \mathrm{fps})$ near the center of the intersection, and 0.85 to $1.04 \mathrm{~m} / \mathrm{s}$ ( 2.8 to $3.4 \mathrm{fps}$ ) entering the Diversion Channel. A large, slow counterclockwise eddy formed adjacent to the straight-line currents in the East Lock approach. This eddy was driving a small clockwise eddy further eastward in the approach. A large, slow clockwise eddy formed in the West Lock approach.

Navigation conditions. With the $170 \mathrm{cu} \mathrm{m} / \mathrm{s}(6,000 \mathrm{cfs})$ flow condition and tows moving east to west (Plate 73), the tows could come out of the East Lock and turn slightly into the current before the head of the tow got out into the current. Controlling the set of the tow was not difficult and getting the tow in alignment to enter the 38.1-m (125-ft) channel that approached the remaining West Lock miter gate was not difficult. With the tows moving west to east (Plate 74), the tow had plenty of maneuvering room before getting into the currents. The tow could be steered slightly into the current and allowed to set. Control of the tow and getting into alignment to enter the East Lock was not difficult.

With the $283 \mathrm{cu} \mathrm{m} / \mathrm{s}(10,000 \mathrm{cfs})$ flow condition and tows moving east to west (Plate 75), the tows still experienced the same current set in the intersection as with the base conditions and Plan G. With both miter gates of the West Lock removed, the head of the tow could make safe passage into the channel that was the West Lock chamber, even if the head of the tow was slightly too far north of the GIWW center line when the head stopped setting southward. If the head of the tow was slightly too far south of the GIWW center line, the stern could be allowed to set southward and rotate the head to the north, or with the extra channel width and no wall to strike, the tow could be brought into the old lock chamber without great difficulty, as long as the stern had not set so far southward in the intersection that the tow grounds on the southwest corner. Navigation from east to west still required steering the tow into the current as the tow cleared the East Lock approach and the tow pilot had to countersteer to regulate the set of the tow with the currents. The difficulty in entering the $22.9-\mathrm{m}(75-\mathrm{ft})$ width 
opening of the West Lock and the wing walls with the base conditions was greatly reduced by removal of the wing walls and the miter gates and increasing the width of the channel to $38.1 \mathrm{~m}(125 \mathrm{ft})$. With the tows moving west to east (Plate 76), navigation conditions were almost the same as with Plan G. The extra maneuvering room created by the removal of the miter gates and wing walls and the extra 15.2-m (50-ft) width of the channel allowed the tow to be steered into the currents before the head of the tow got out into the current. This made controlling the set of the tow much less difficult than with the base conditions. By better controlling the set, it was much less difficult to get the tow into alignment to enter the East Lock. 


\section{Summary and Conclusions}

\section{Limitations of Model Results}

Analysis of the results of this investigation was based on a study of the effects of various plans and modifications on current directions and velocities and the effects of the resulting currents on the behavior of the model towboat and tow. In evaluating experimental results, it should be considered that small changes in current directions and velocities were not necessarily changes produced by a modification of the plan since several floats introduced at the same point may follow different paths and move at somewhat different velocities because of pulsating current and eddies. Slight variations in the discharge can also be introduced into the model due to the use of a venturi meter that has an accuracy of about plus or minus 5 percent to measure the discharge. Current directions and velocities shown in the plates were obtained with floats submerged to a depth of a loaded barge [3.0 $\mathrm{m}(10 \mathrm{ft})]$ prototype and are indicative of the currents that would affect the behavior of tows.

The small scale of the model and the limited number of flow conditions evaluated made it difficult to reproduce all of the unique hydraulic characteristics of the prototype or to measure water-surface elevations within an accuracy greater than about $\pm 0.03 \mathrm{~m}(0.1 \mathrm{ft})$ prototype. Current directions and velocities taken from the model were based on steady flows and river stage, and predominately no flow through the locks. The model was of the fixed-bed type and was not designed to reproduce overall sediment movement that might occur in the prototype with the various plans; therefore, changes in channel configuration resulting from scouring and deposition caused by these plans and any resulting changes in current directions and velocities were not evaluated.

The results and conclusions reached on the various plans evaluated in the model are presented for planning purposes and should not be used for final design of the project without additional model experiments to verify navigation conditions with the proposed modification.

\section{Summary of Results and Conclusions}

The following results and conclusions were developed during the investigation: 
a. Plan A. L-head dike. The training dike as examined for Plan A (Figure 3) appeared to provide moderate improvements to navigation, based on operation of the model tow. This plan was presented to representatives of the towing industry during meetings in September 1998. Based on their observations of transits between the locks with the model tow, they determined that the increase in velocities along the eastern side of the intersection offset any gains in relatively slack water along the western side.

b. Plan B. Dredging intersection. Dredging of the intersection for Plan B (Figure 4) decreased the effective currents on the crossing tows and provided moderate improvements to navigation. The model examined only the "as dredged" condition. As the intersection shoals, which will likely occur from the heavy sediment load carried by the Colorado River, navigation conditions will return to that of the existing conditions.

c. Plan B-1. Dredging and L-head dike. The addition of the dike used for Plan A with the dredging used for Plan B, as done for Plan B-1

(Figure 15), provided navigation conditions slightly better than the existing conditions but not as good as with just the dredging alone. As mentioned previously, the model could not be used to determine how effective the dike would be at reducing shoaling in the intersection, but could be used to determine how such a structure would impact navigation. Also, the model did not reflect any channel bed changes that might have occurred from either shoaling or scouring as the result of the dike and the subsequent current pattern changes that they would cause.

d. Flow through the locks. Model evaluations demonstrated that navigation conditions become worse when there is significant flow through the locks. This suggests that closure of the second gate of a lock during conditions where there can be significant flow through that lock could provide some improvement of navigation conditions in the prototype.

e. Velocity comparisons of existing conditions and Plan B. Velocity measurements taken in the intersection of the Colorado River and GIWW (Figures 5-14) show that dredging the channel provides greater water transport underneath the tow than with the existing conditions, reducing the effect of the currents on the tow and reducing the difficulty of navigating across the intersection.

f. Plan C. Reconstruction Southwest Corner. Restoration of the southwest corner on the Colorado River/GIWW intersection for Plan C (Figure 16) did not significantly improve navigation conditions. The channel bed was not modified to reflect any scouring that might occur off the channelward edge of the corner or along the southeast corner down to the closure dam. Any scour that might occur from the restoration of this point might have an influence on navigation conditions. Potential benefits to navigation of having the corner as an enhanced "landing zone" or pivoting a tow off the enlarged corner could not be evaluated in the model. 
g. Plan D. Training Structures for GIWW/Bypass Improvements. The dikes installed and evaluated for Plan D (Figure 17) moderately improved navigation conditions past the Bypass Channel during ebb tide flows. Navigation conditions with flood tide flows were approximately the same as with the existing channel conditions.

h. Plan E. Removal of Southeast and Southwest Corners. Removal of the southeast and southwest corners of the Colorado River/GIWW intersection for Plan E (Figure 18) significantly degrades navigation conditions as compared with the existing conditions.

i. Plan F. Relocation of Bypass Channel. Evaluation of placement of the Bypass Channel in relation to the placement of the Matagorda Bridge for Plan F (Figures 19-30) determined that the Bypass Channel should be no less than two tow lengths eastward of the bridge for adequate navigation conditions.

j. Plan G. Remove south gate from West Lock. Removal of the south miter gate from the West Lock and widening the approach to $38.1 \mathrm{~m} \mathrm{(125 \textrm {ft } )}$ assymetrically to the GIWW center line for Plan G (Figure 31) provided significant navigation improvements for tows moving west to east and moderate improvement for tows moving east to west. The tendency for tows to strike the north wing wall of the West Lock was still present with this plan.

k. Plan G-1. Removal of both eastern gates, West Lock. Removal of both the north and south miter gates from the West Lock and widening the channel to $38.1 \mathrm{~m}(125 \mathrm{ft})$ symmetrically to the GIWW center line for Plan G-1 (Figure 32) significantly improved navigation conditions for both directions of travel. The model did not allow evaluation of navigation through the remaining set of miter gates for the West Lock. Since the original design had only the single set of miter gates to be used as a flood control gate and tows at that time could not pass through against a strong current, it is suggested that further study be devoted to examining navigation through the remaining gates.

\section{Recommendations}

Plan G-1 (removal of the east gates of the West Lock), as evaluated in the navigation model, appeared to provide the most significant improvement to navigation conditions of any of the plans examined, but would likely be the most expensive to construct. Further study to determine if use of a single flood gate would provide acceptable navigation conditions when there is significant head differential between the GIWW and Colorado River would be required.

Plan A (installing a training structure along the right bank of the Colorado River) could not consider how this training structure would change the bed scour and deposition patterns in and below the intersection. Typically with a structure of this type, there would be an expectation of some scour along the channelward 
edge and immediately downstream of the trailing end of the dike. Some indication of how this scour might influence current velocities can be seen in the evaluation of Plan B-1 (dredging in intersection and training work from Plan A). Velocities in the intersection were reduced from a peak of $1.04 \mathrm{~m} / \mathrm{s}(3.4 \mathrm{fps})$ with only the training work of Plan A in place to $0.82 \mathrm{~m} / \mathrm{s}(2.7 \mathrm{fps})$ with the training work and dredging of Plan B-1.

The navigation study also could not predict how the shoaling that has occurred in the entrance to the old Colorado River channel near the base of the Diversion Dam would be affected. None of the plans examined, except for total removal of the southeast and southwest corners for Plan E, considered any potential for scouring or shoaling in this area. Enhancement of the southwest corner, as performed for Plan C, might have an impact on this shoaled area. If this material were to be dredged or scoured away, flow through the intersection might tend to be directed more toward the old channel briefly before coming back into the Diversion Channel. This would be a condition similar to that when the project was first completed, a time in which the tow operators say that navigation conditions were better than at present.

If an effective protection plan is developed for an enhanced Southwest Corner, it is recommended that numerical hydrodynamic and sediment studies be performed to determine how this improvement will affect currents at the intersection and the shoaled area near the base of the Diversion Dam. If this shoaled material is shown to have some tendencies to scour it is suggested that evaluation of dredging of this shoaled material be considered to determine if the area will maintain itself, scour or shoal, and if so, at what date. Based on plan comparisons of changes to current speed and direction through the intersection may indicate conditions that might improve navigation. It is also recommended that some type of training work along the right bank of the Colorado River be evaluated with both sediment and current models in conjunction with results from the enhancement of the Southwest Corner and dredging/ scouring in the old channel. If the sediment and current modeling yield favorable results, it would then be recommended that the final plan be installed in the navigation model to qualify navigation conditions. 


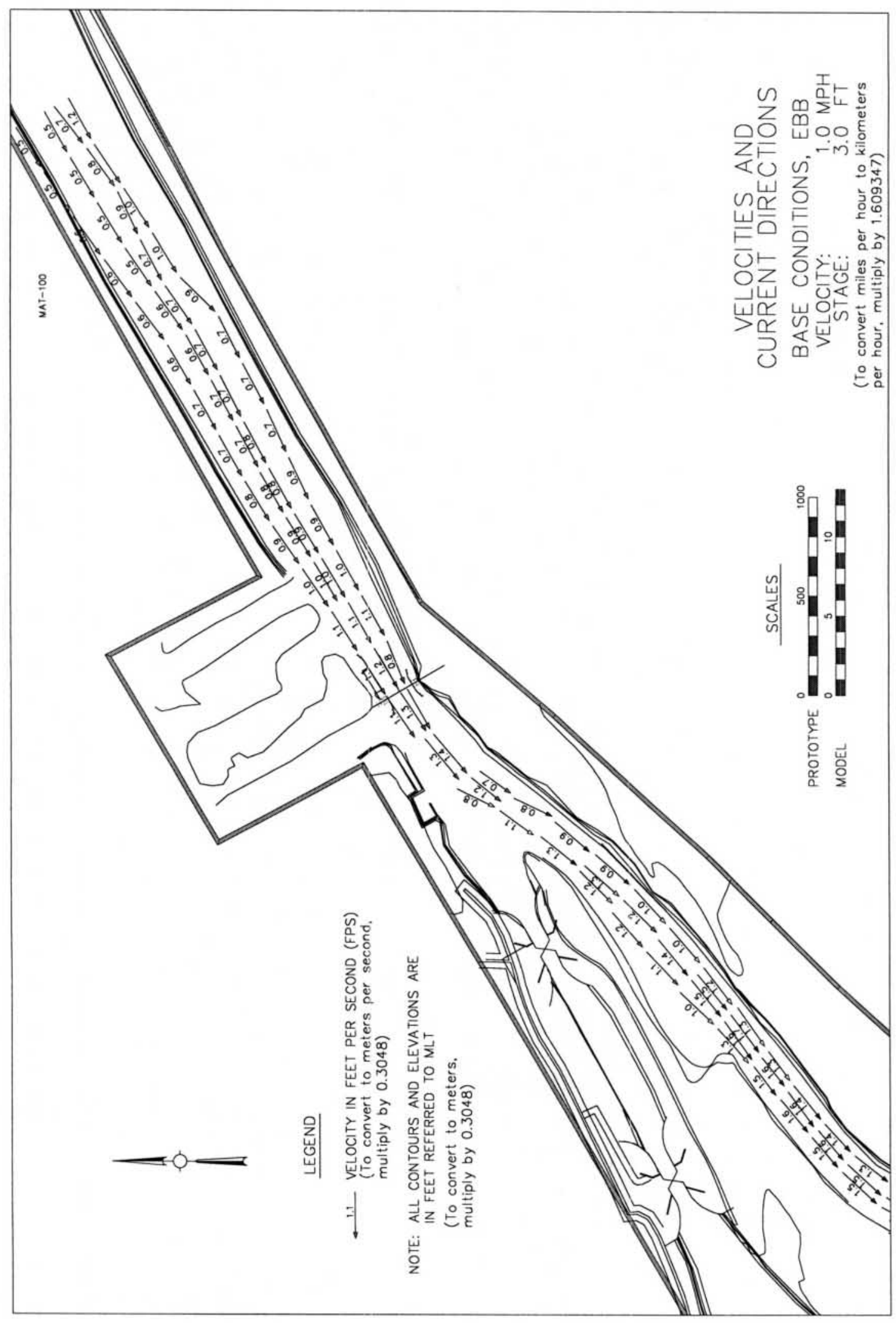

Plate 1 


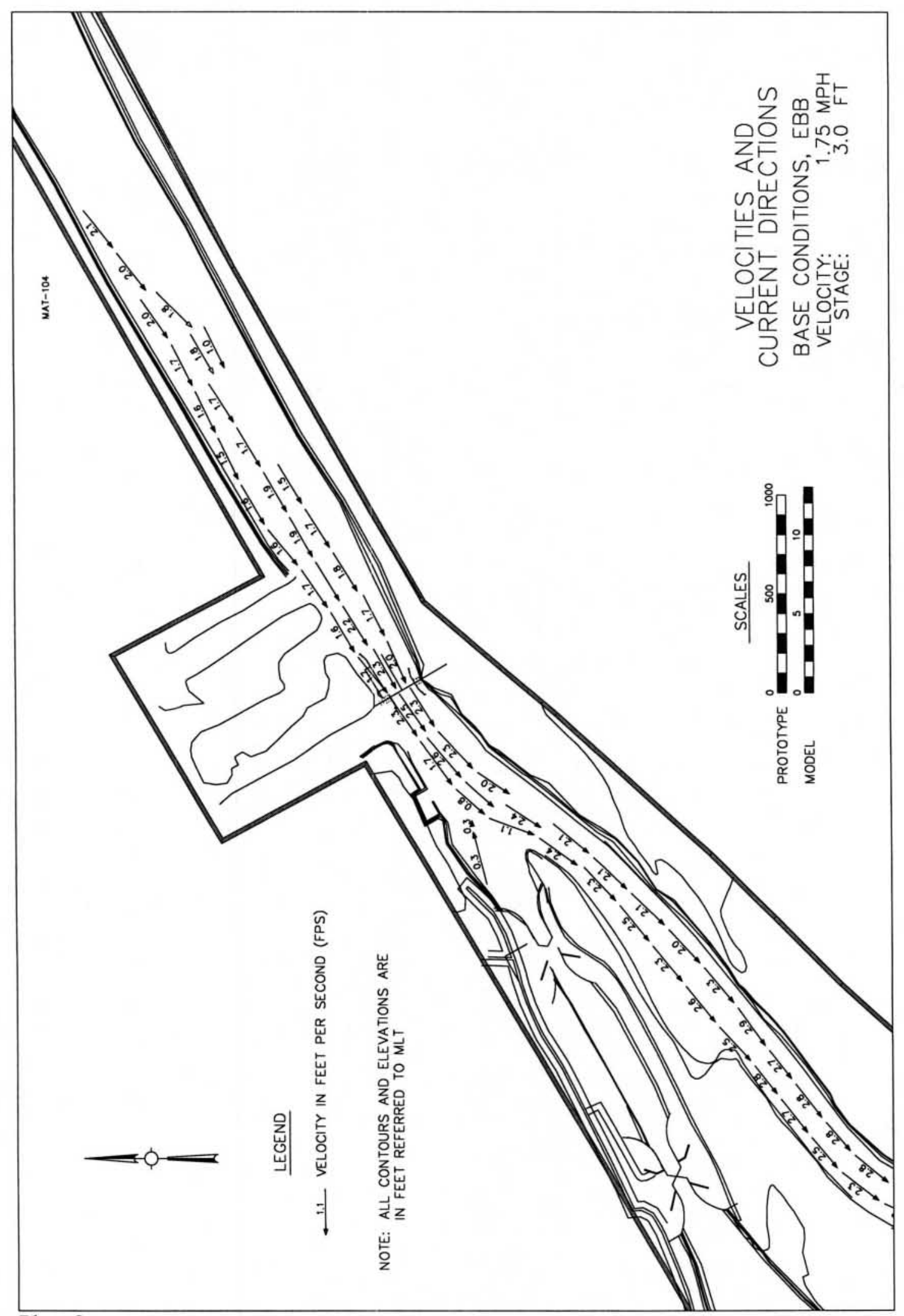

Plate 2 


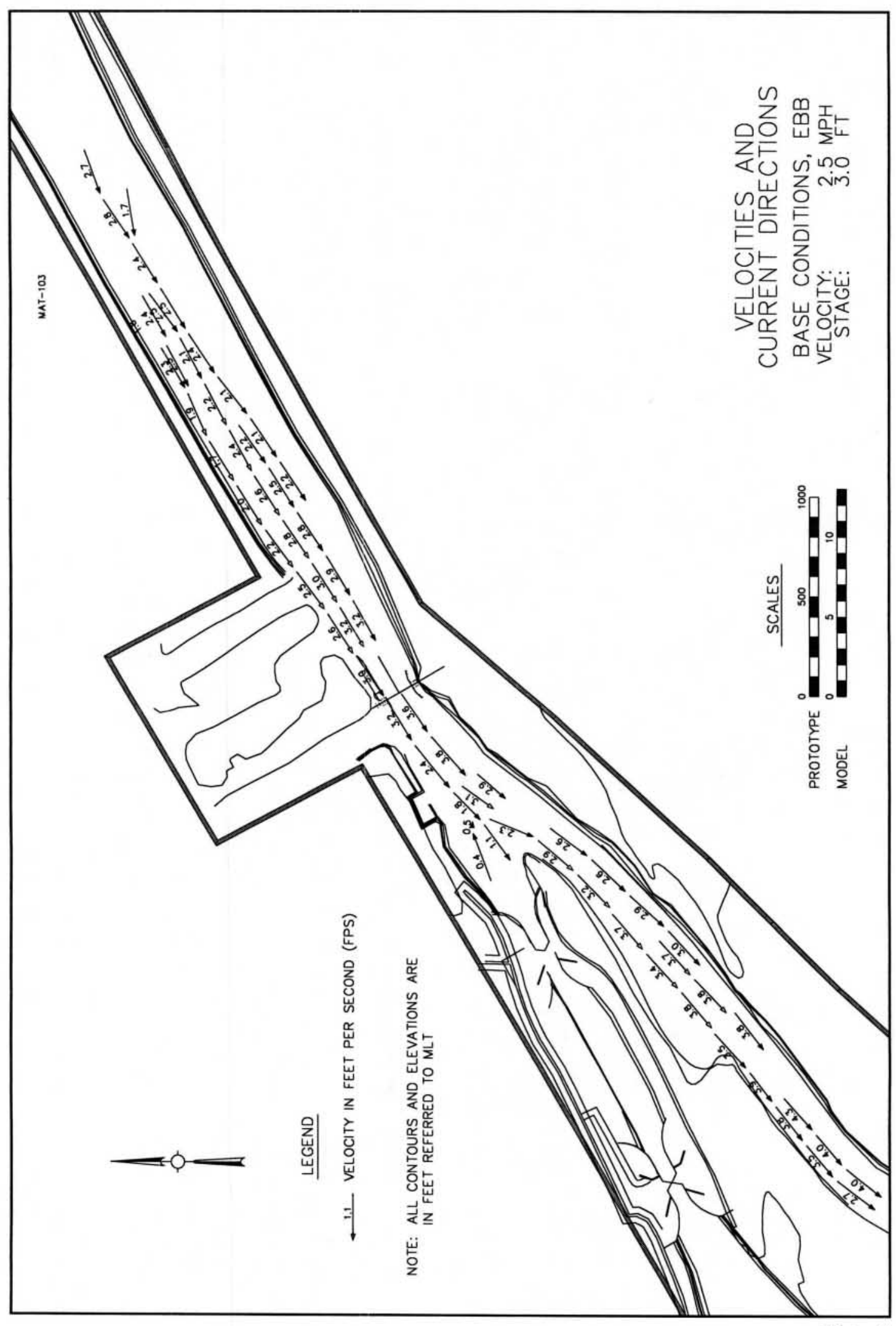

Plate 3 


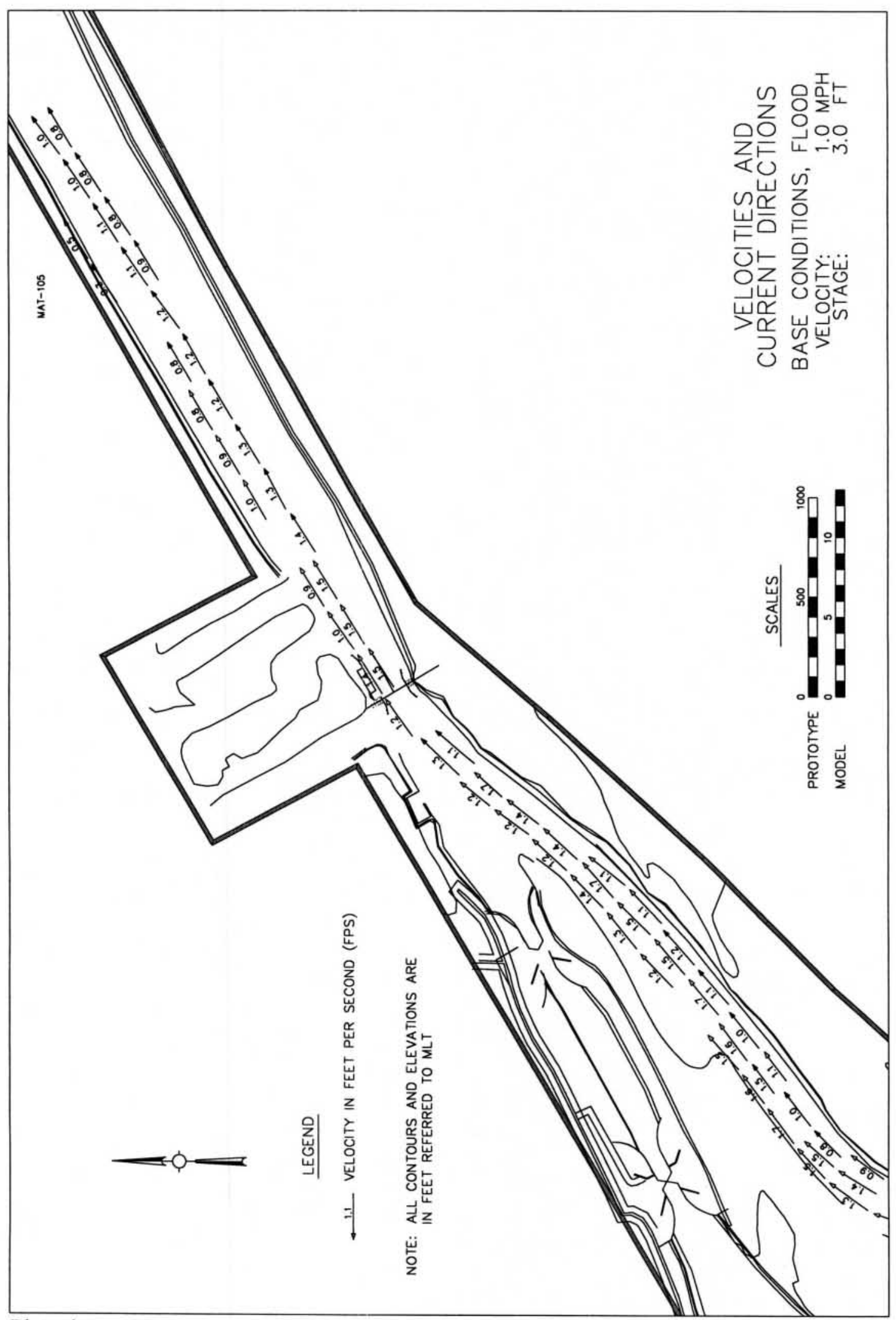

Plate 4 


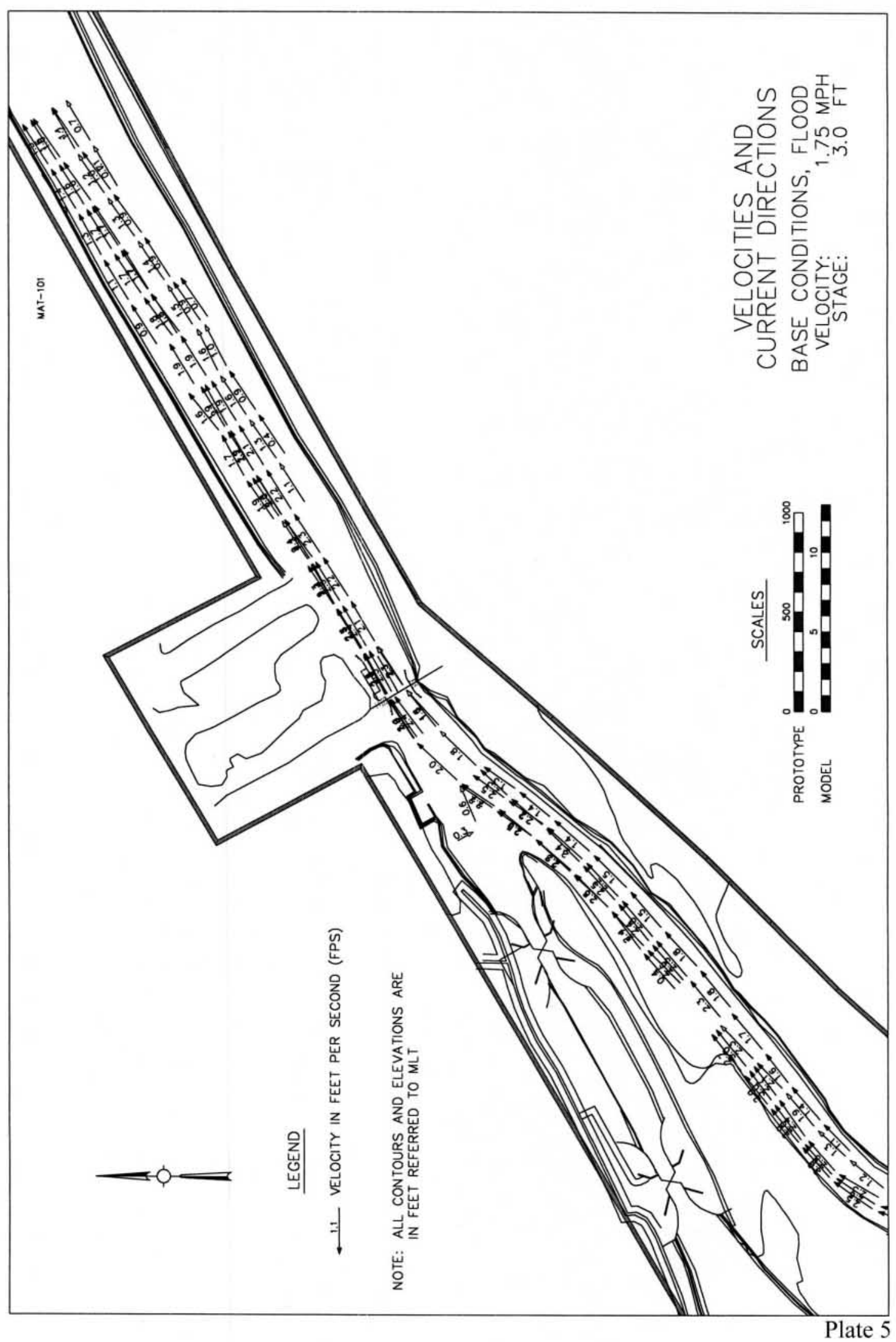




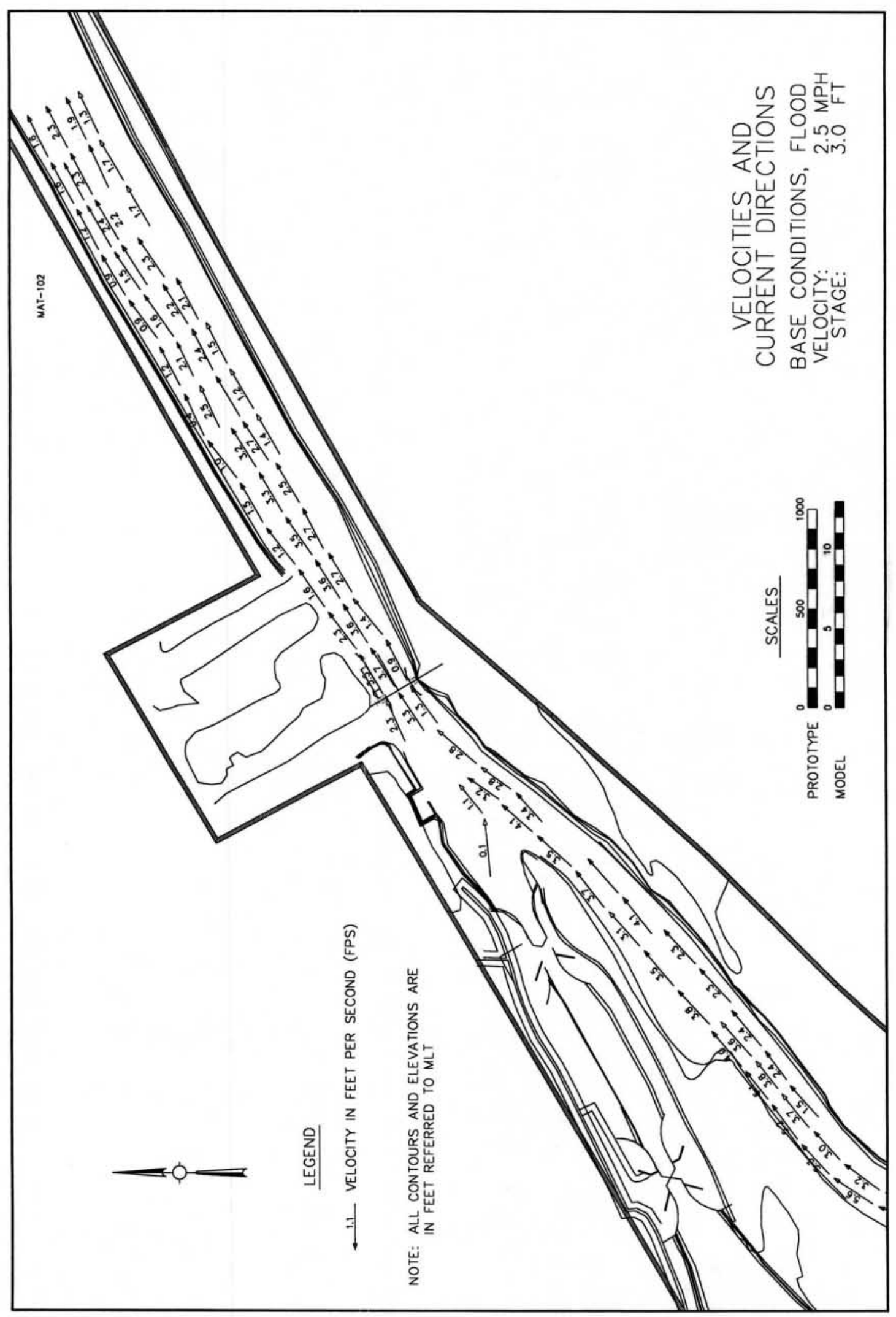

Plate 6 


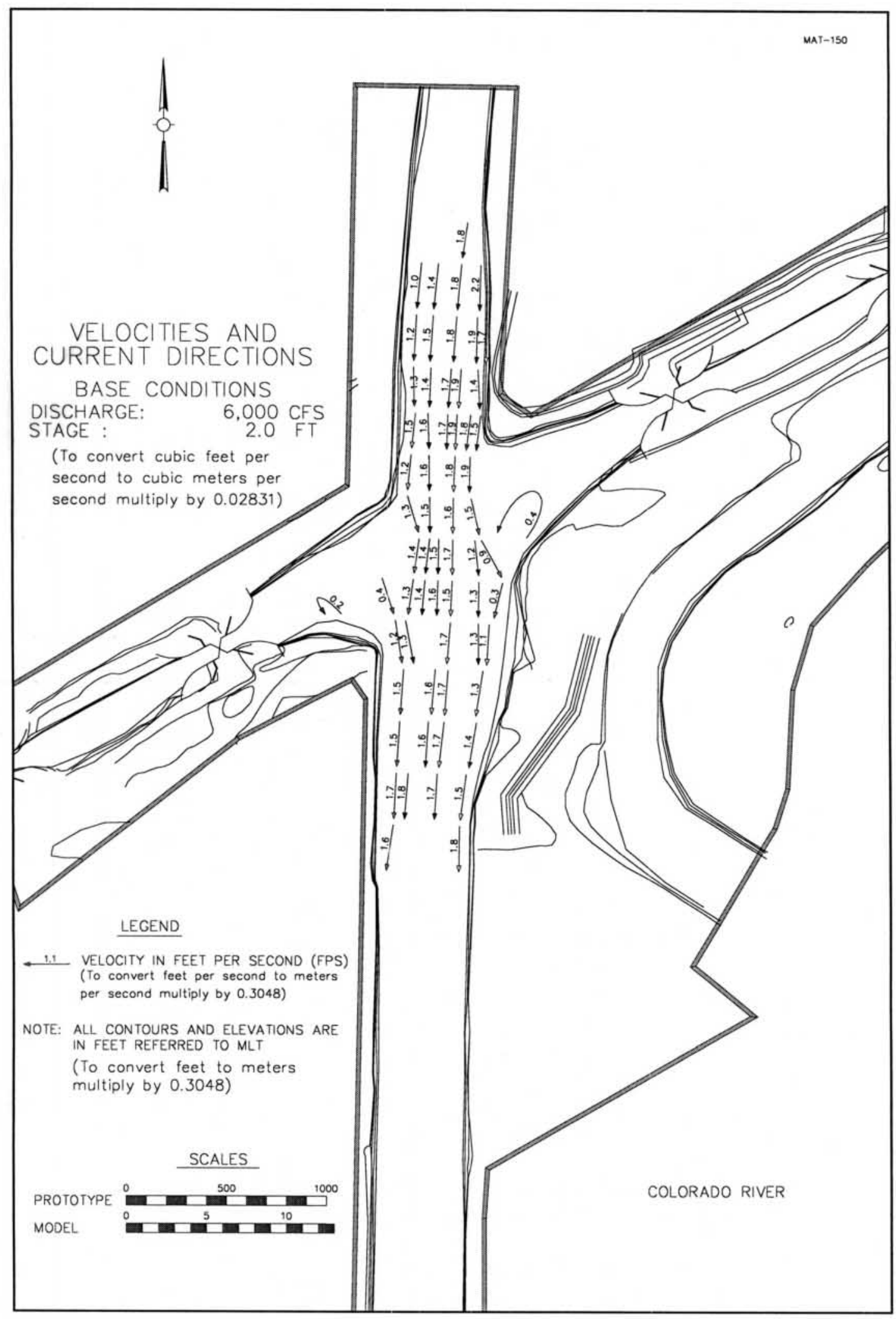

Plate 7 


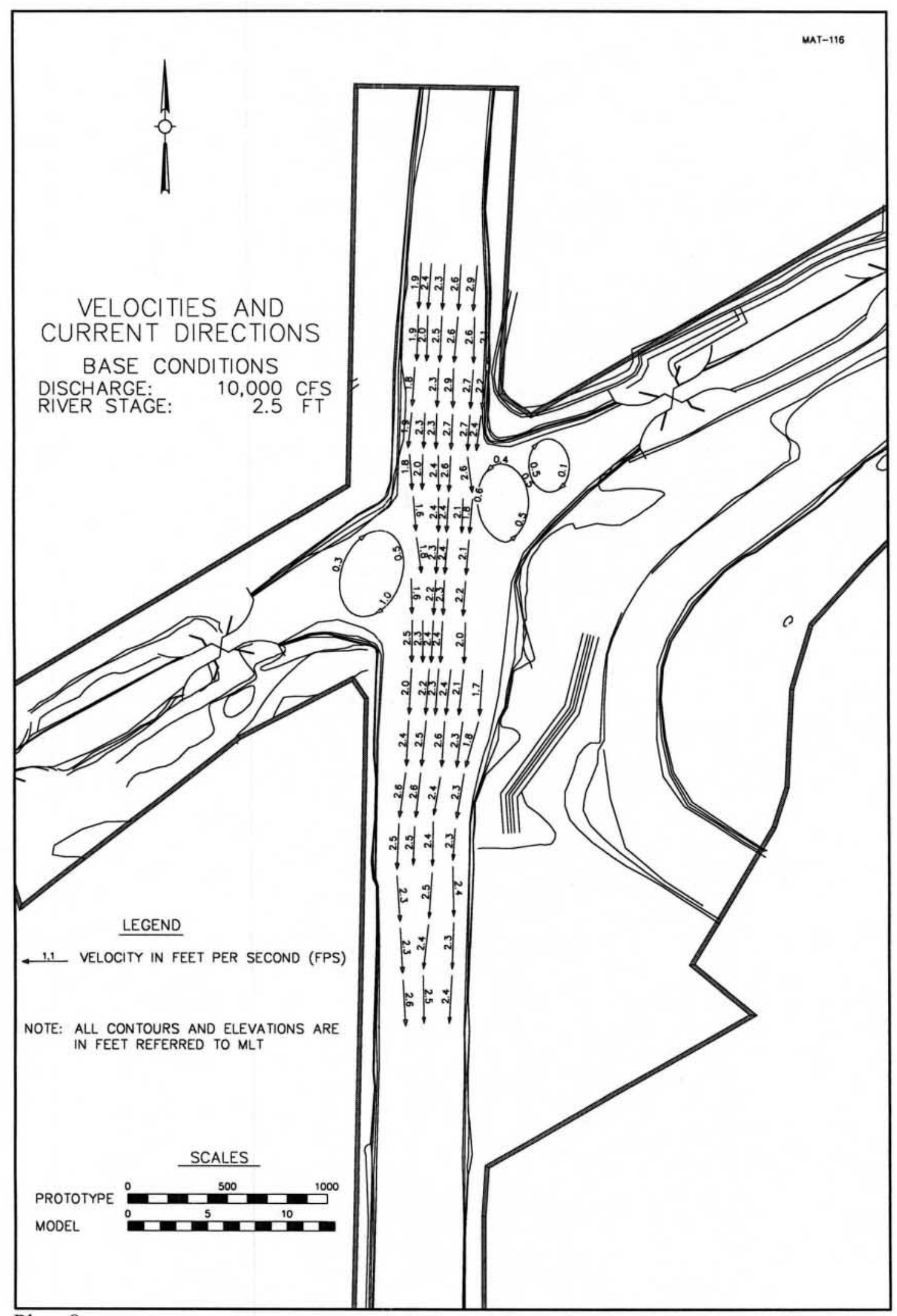

Plate 8 


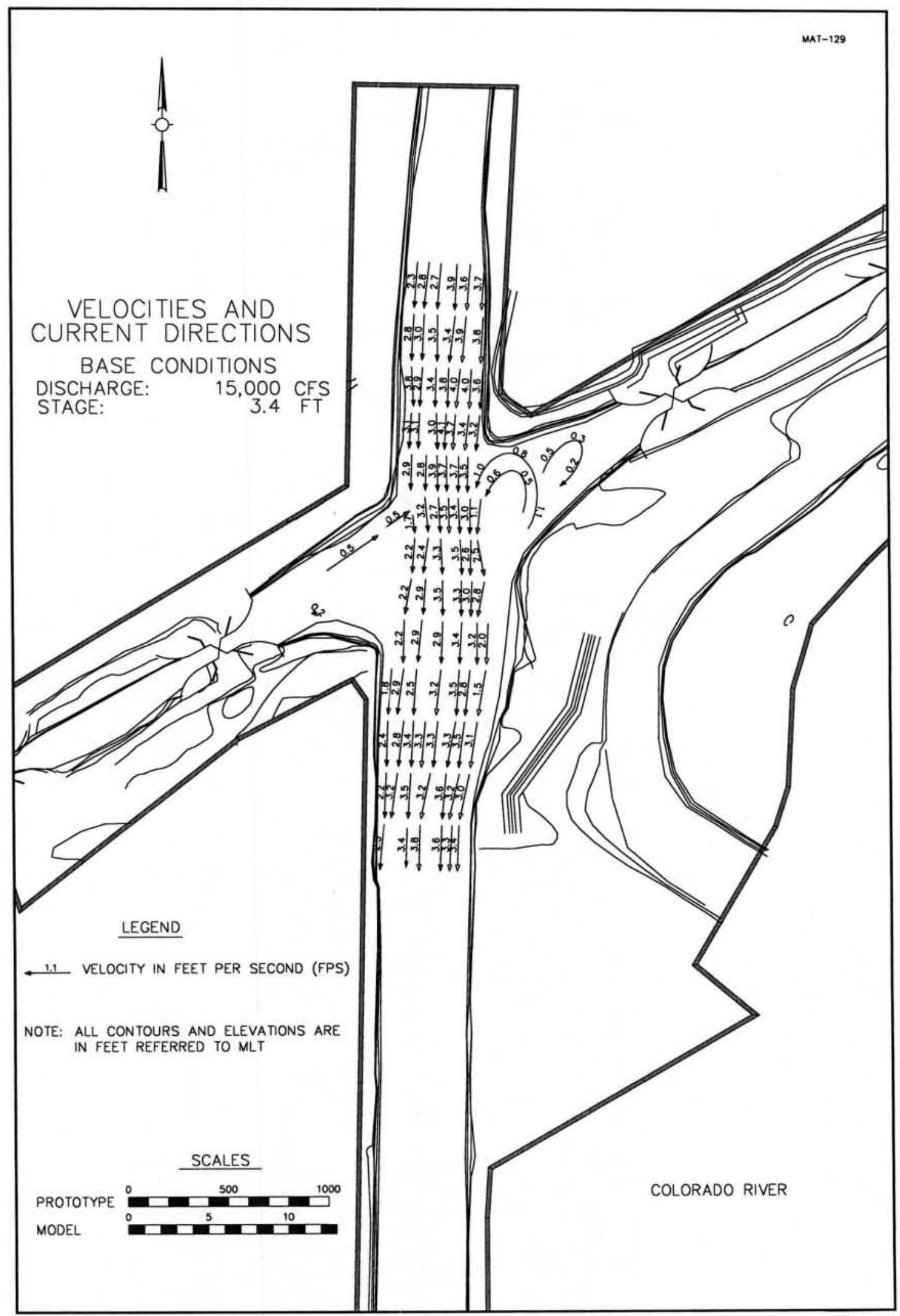

Plate 9 


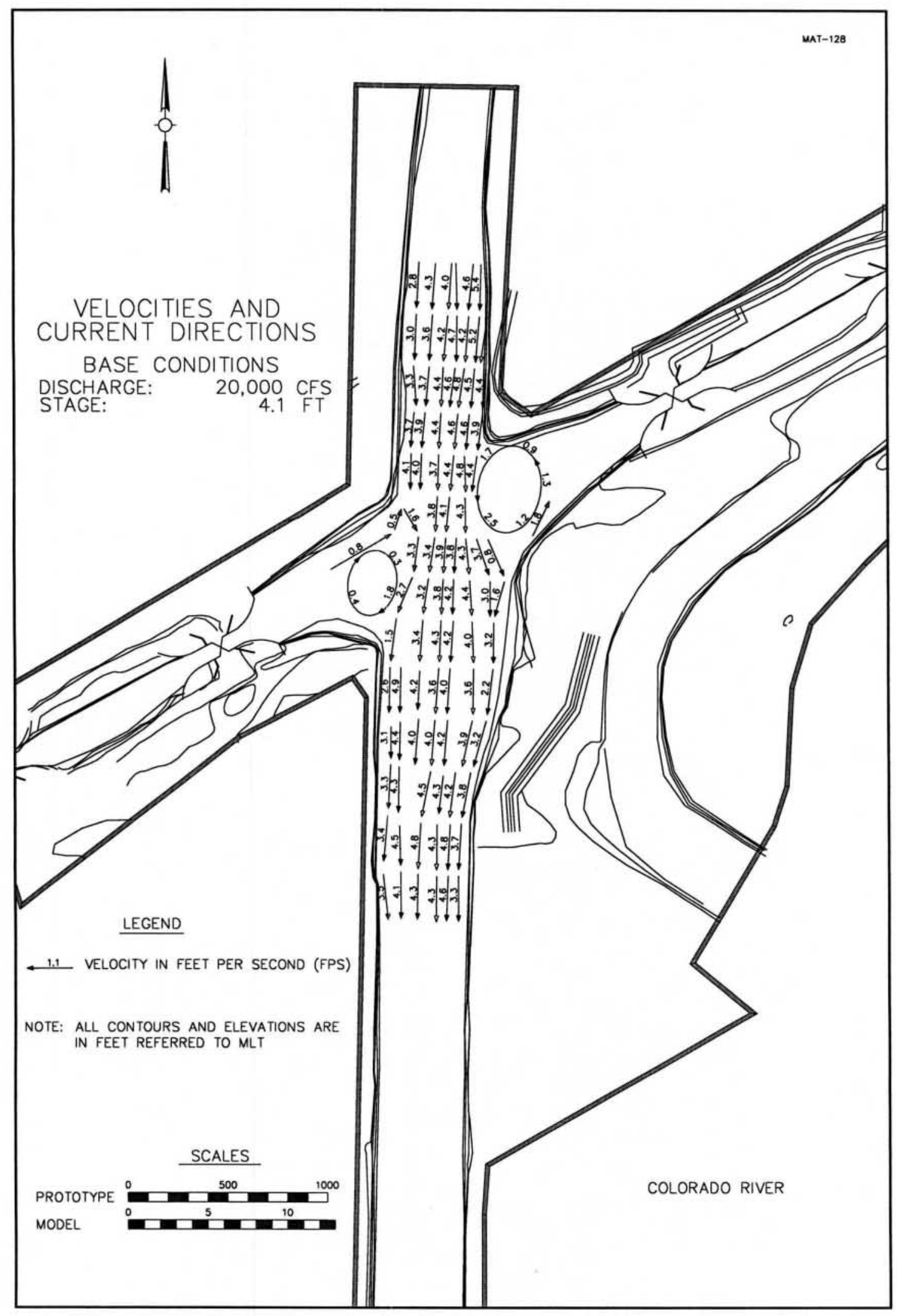

Plate 10 


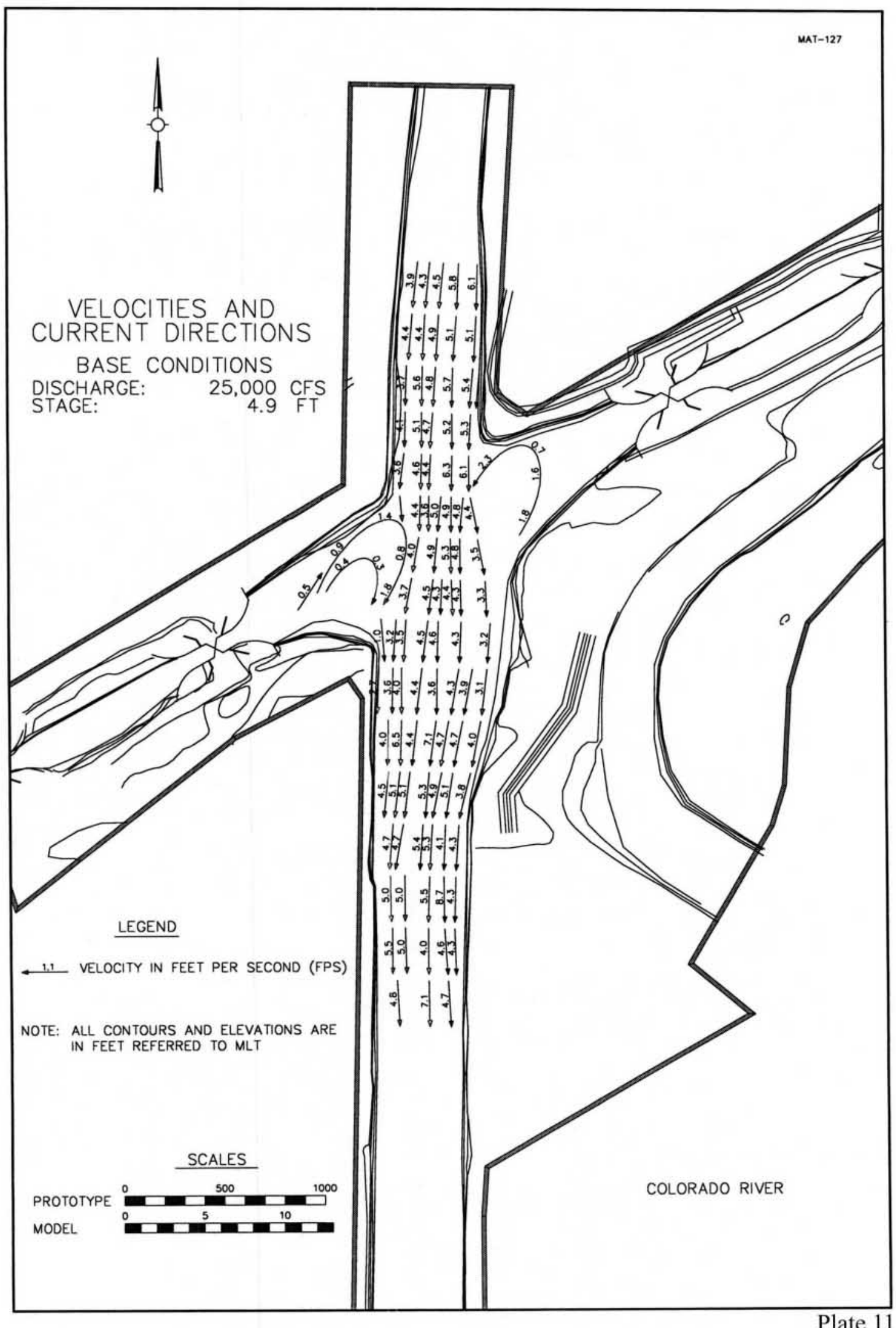




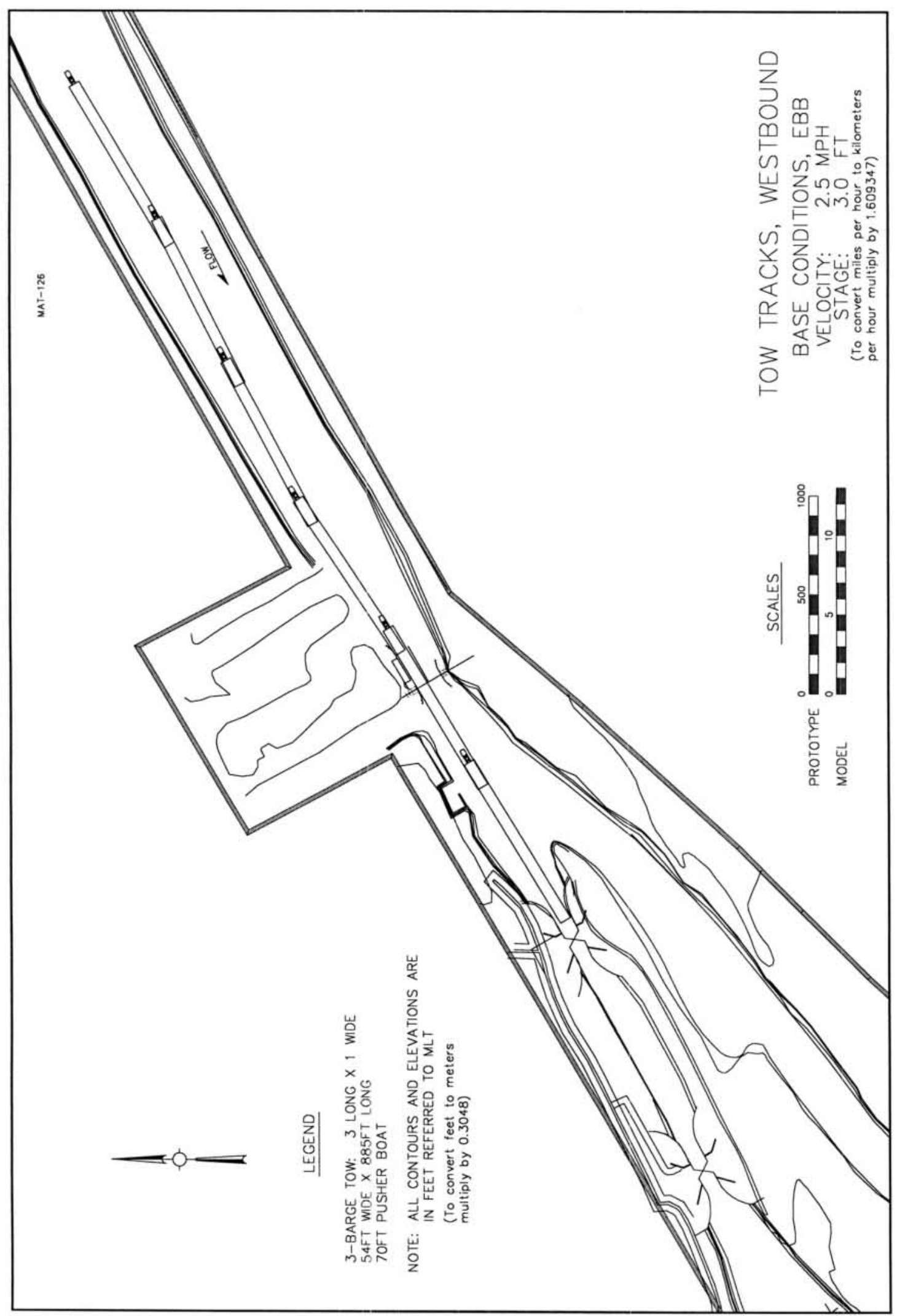

Plate 12 


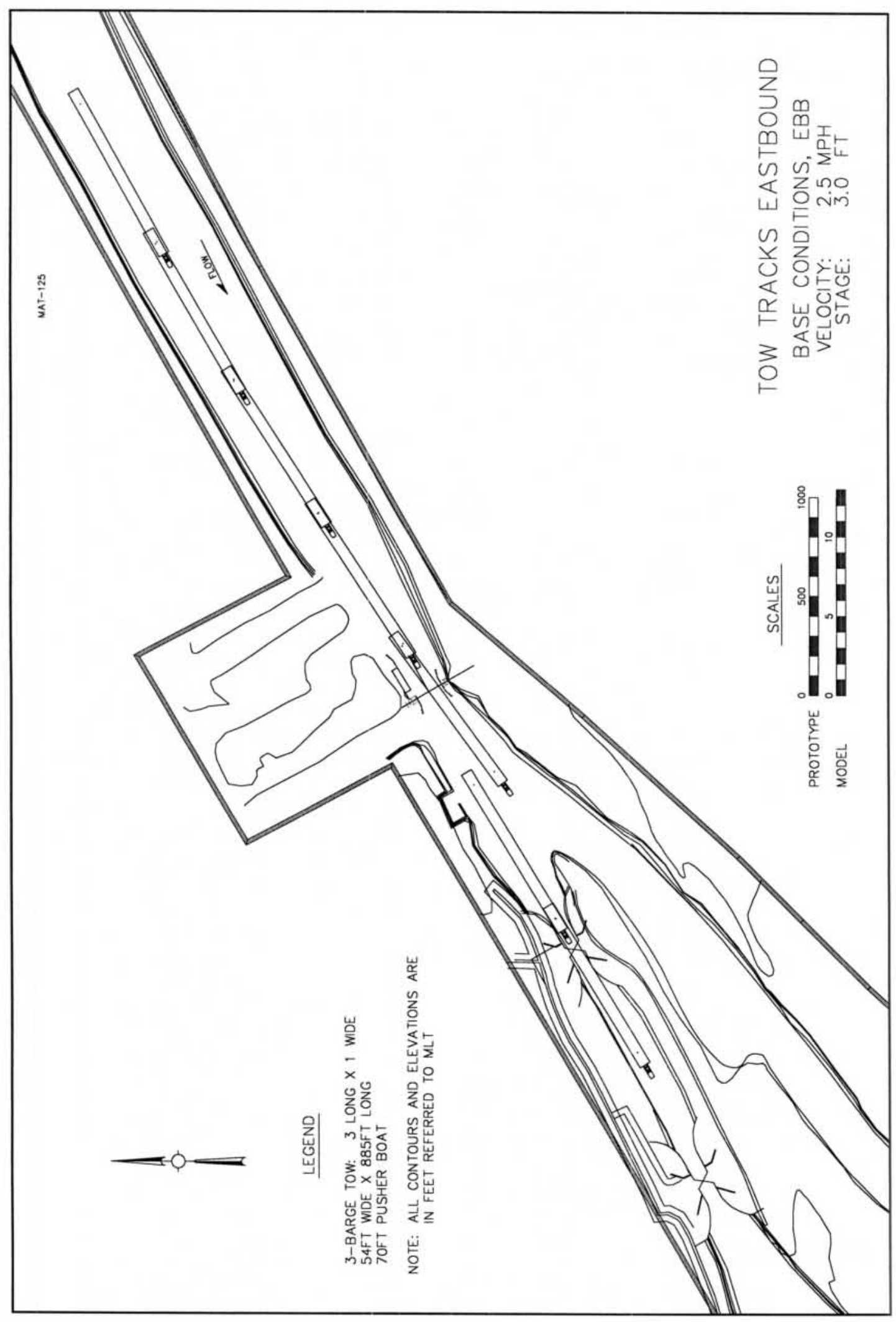

Plate 13 


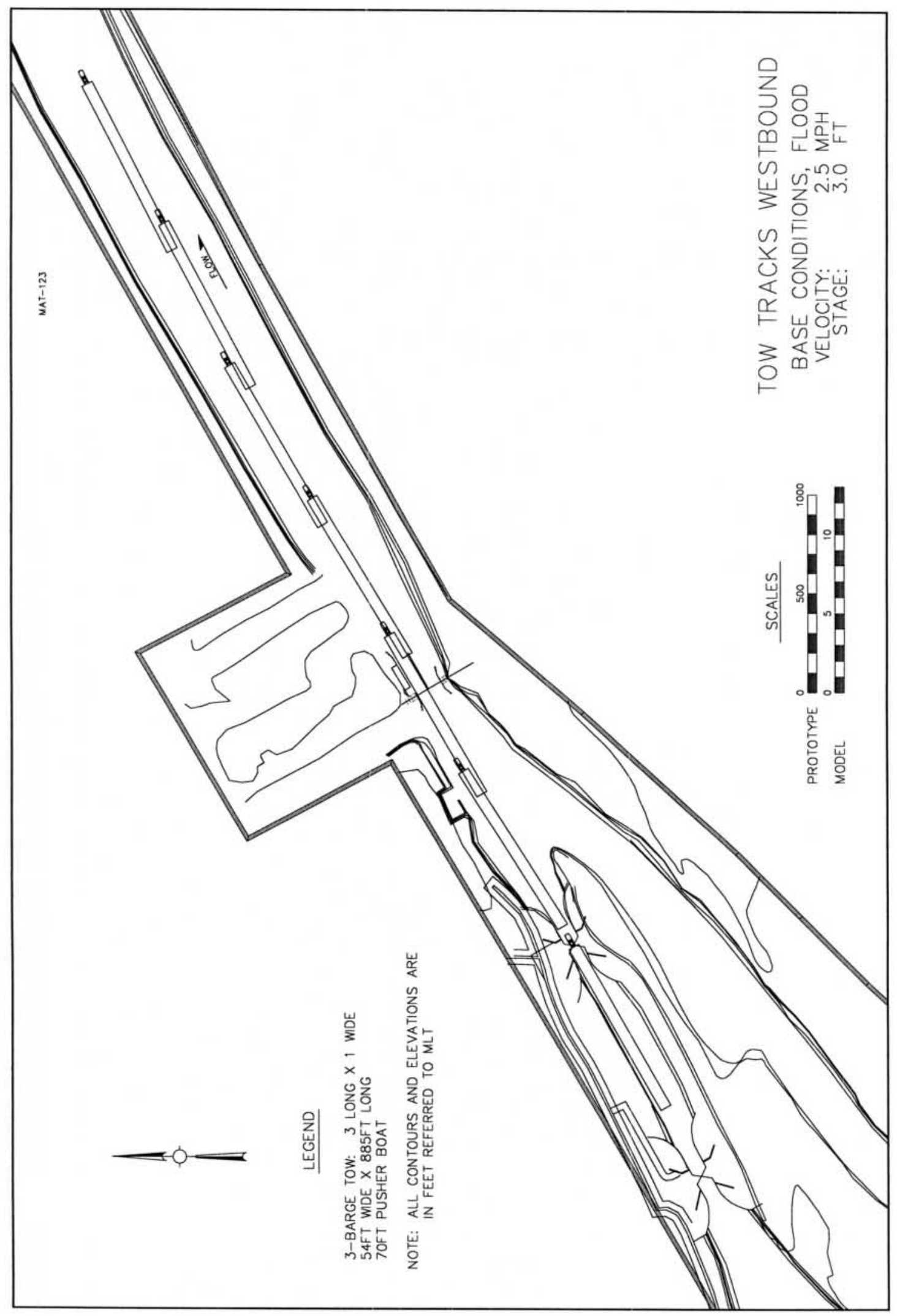

Plate 14 


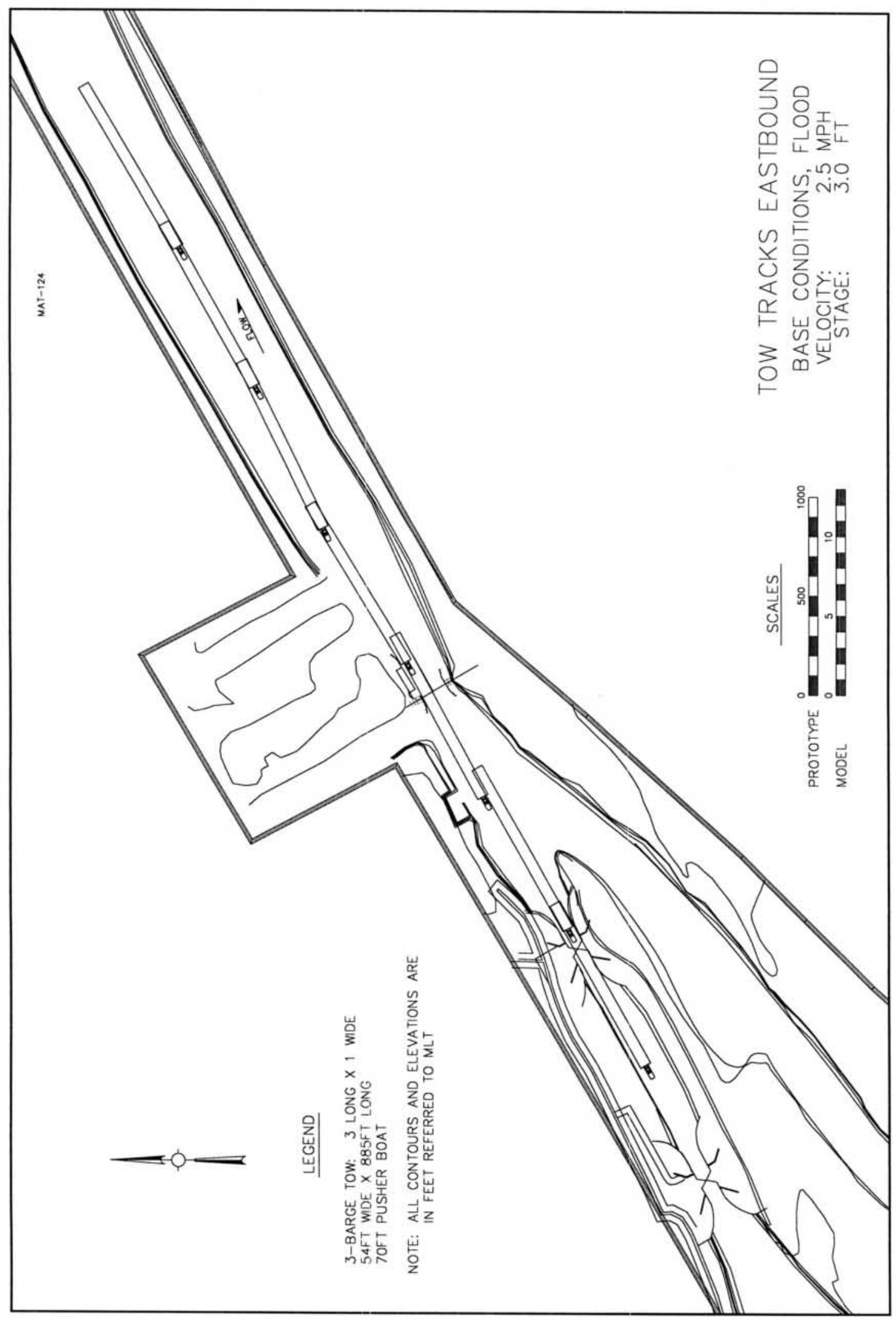

Plate 15 


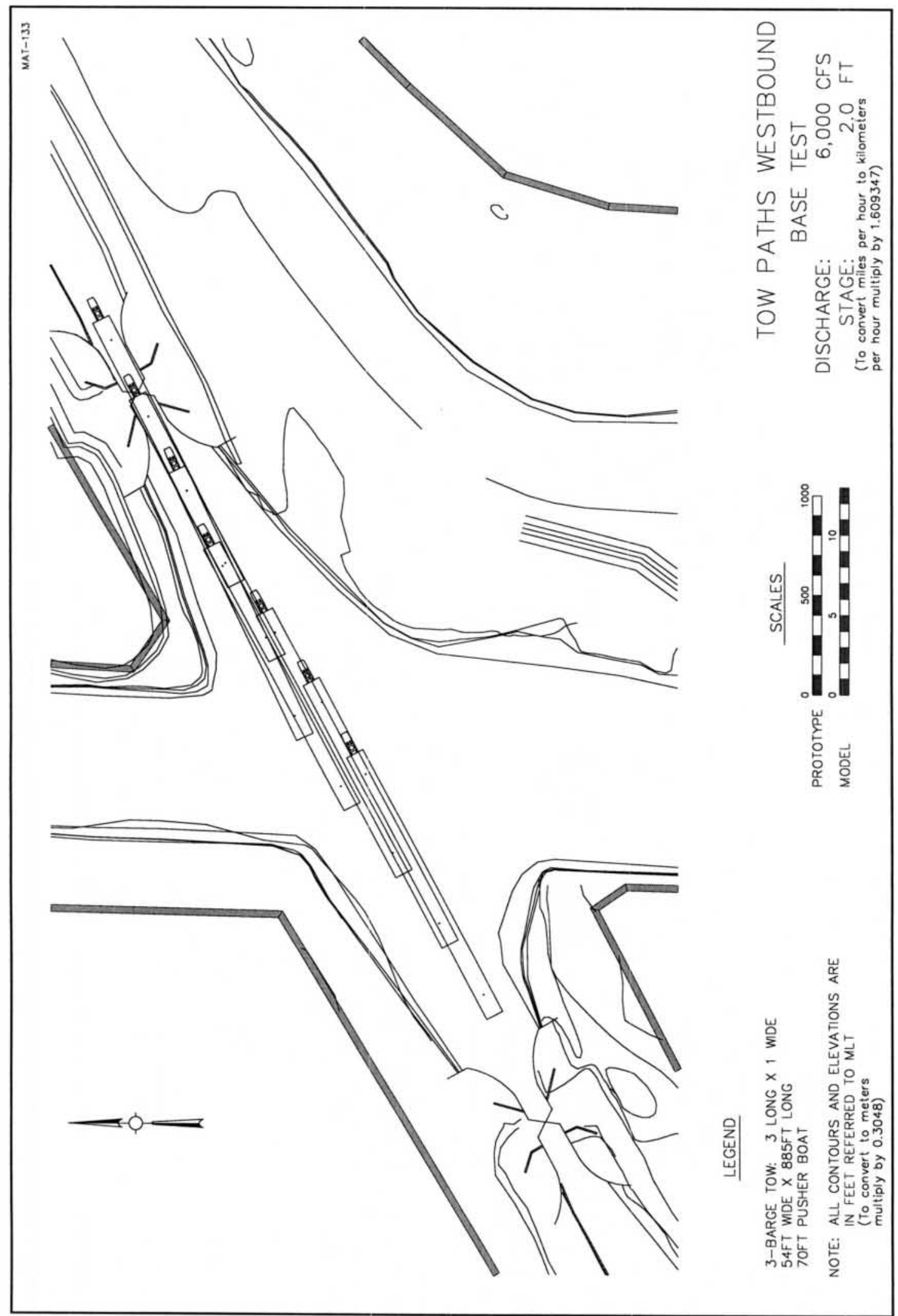

Plate 16 


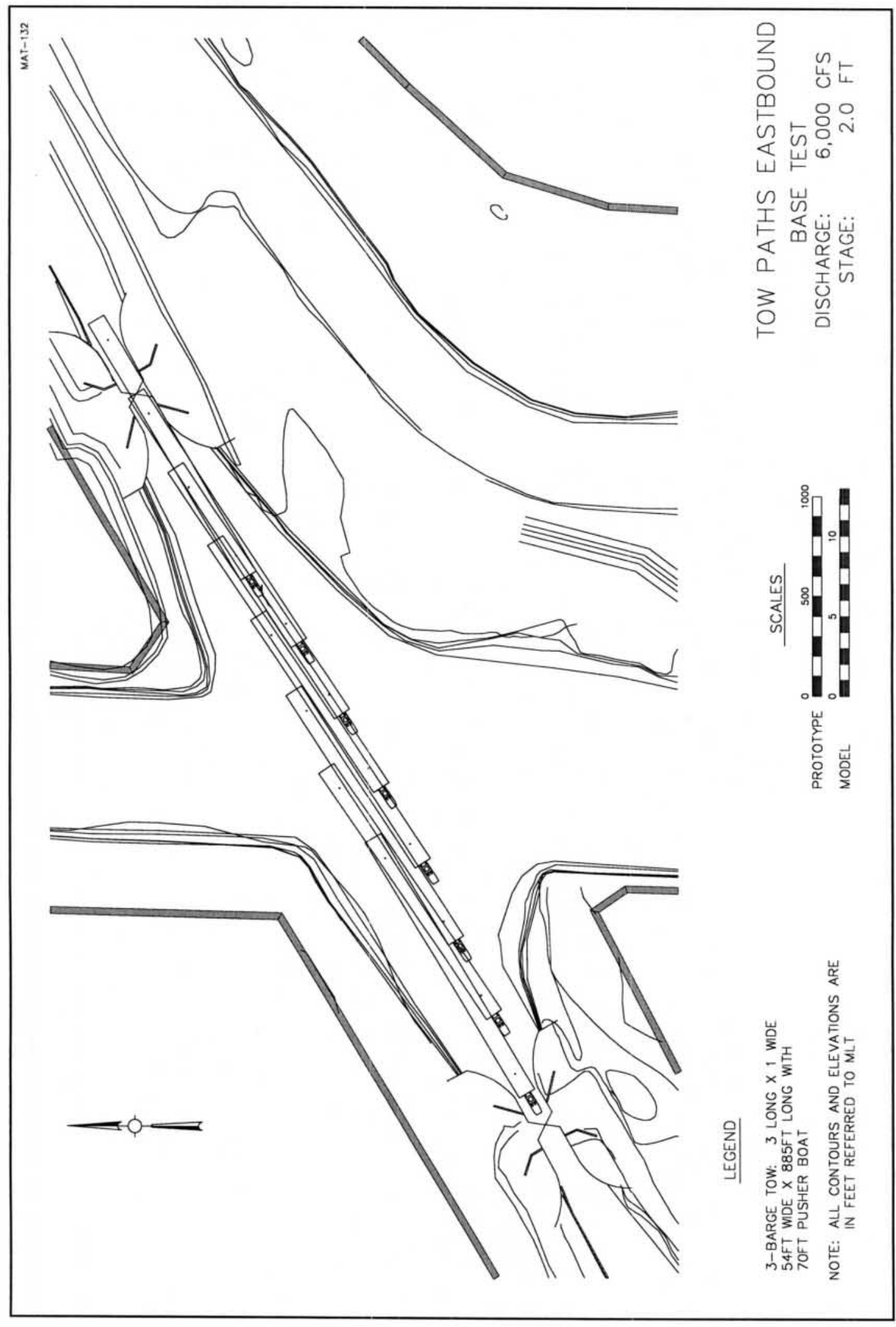

Plate 17 


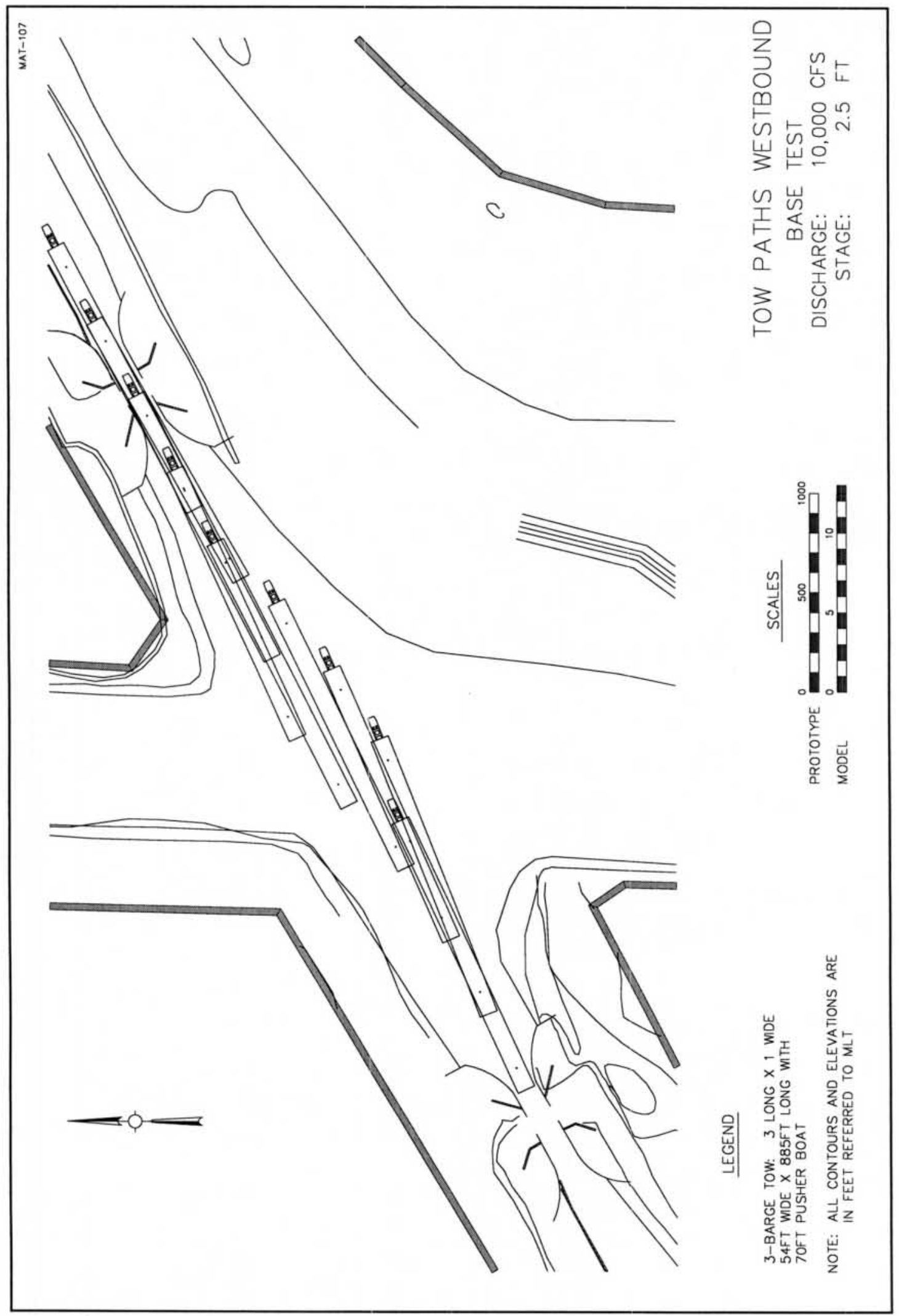

Plate 18 


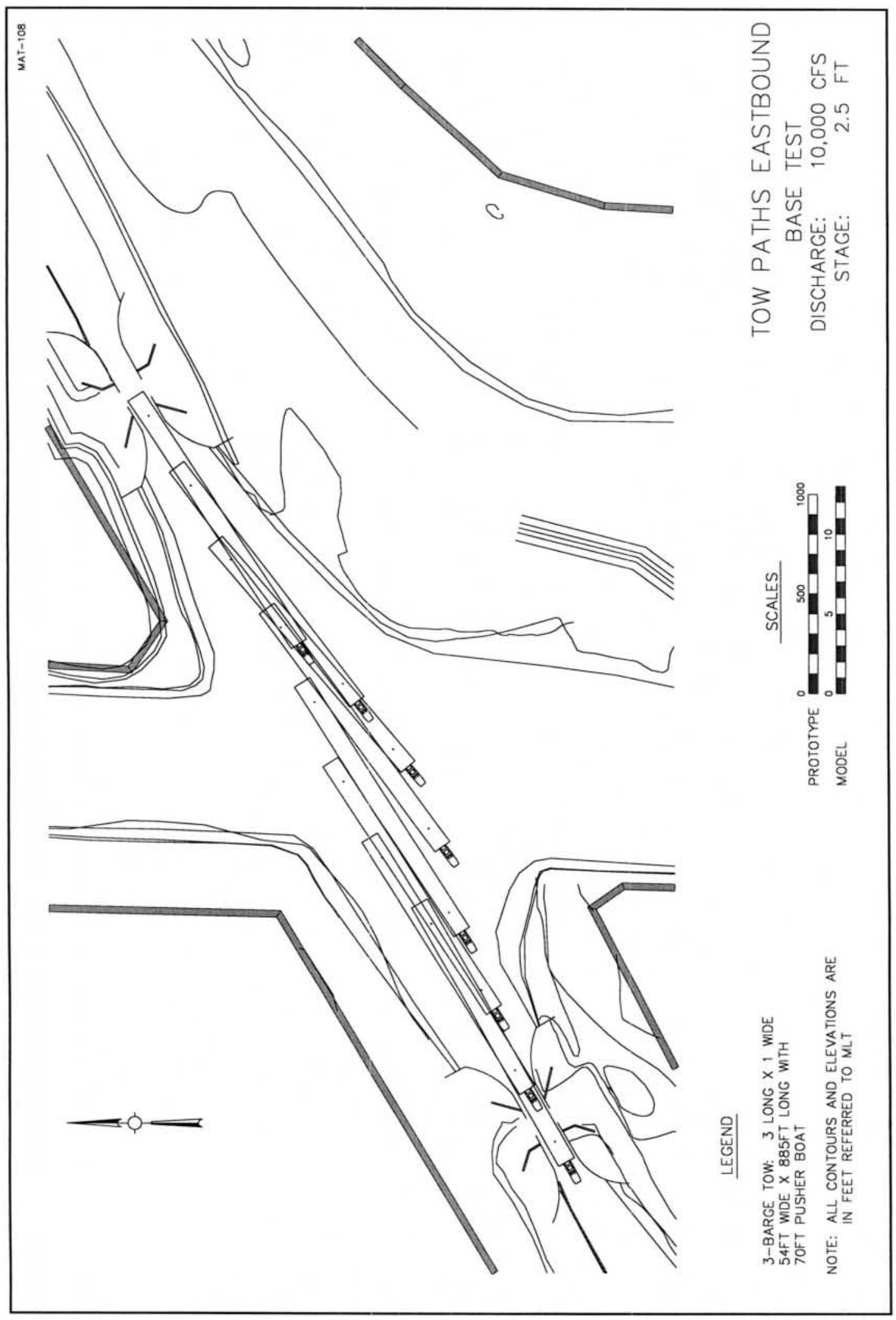

Plate 19 


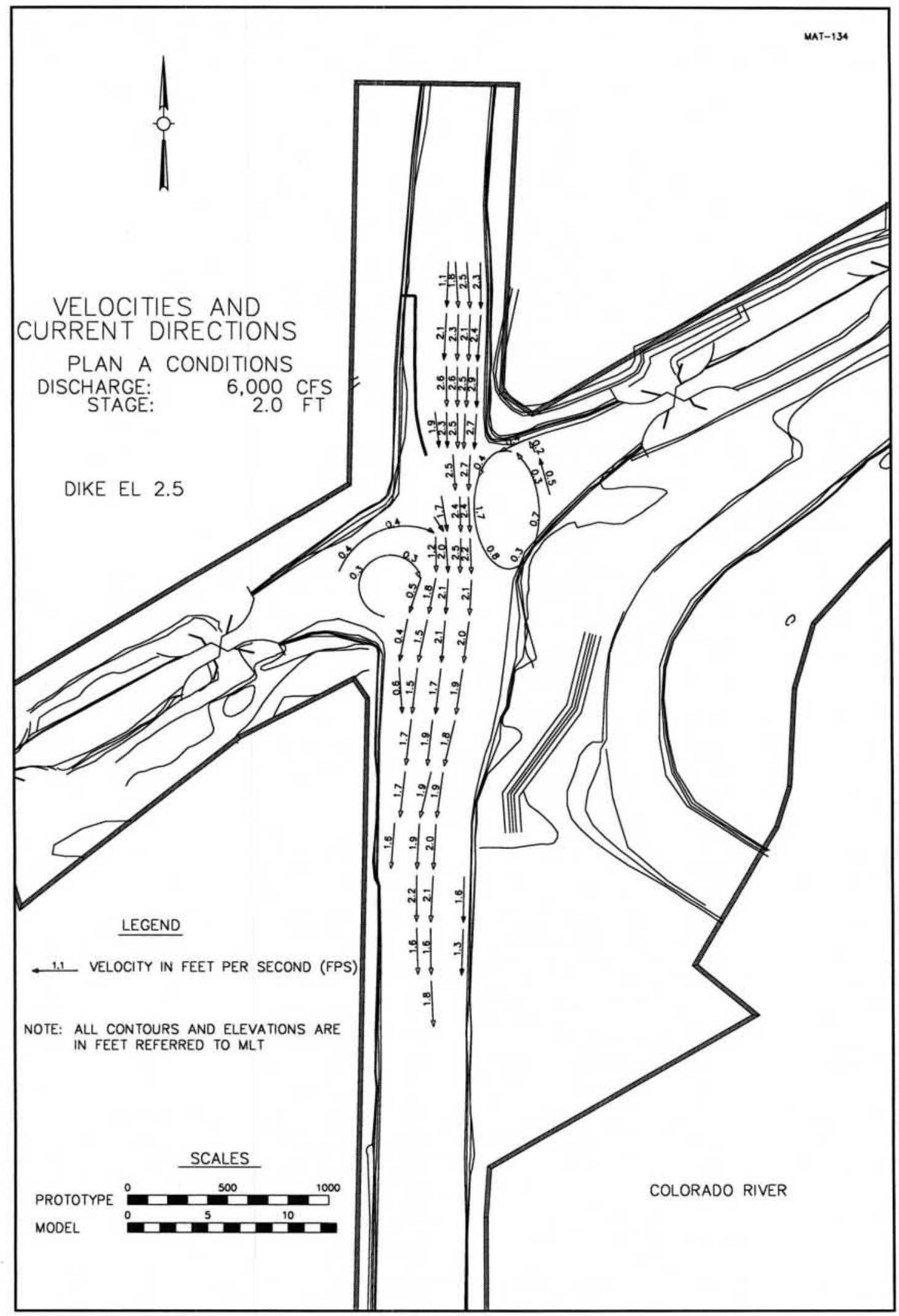

Plate 20 


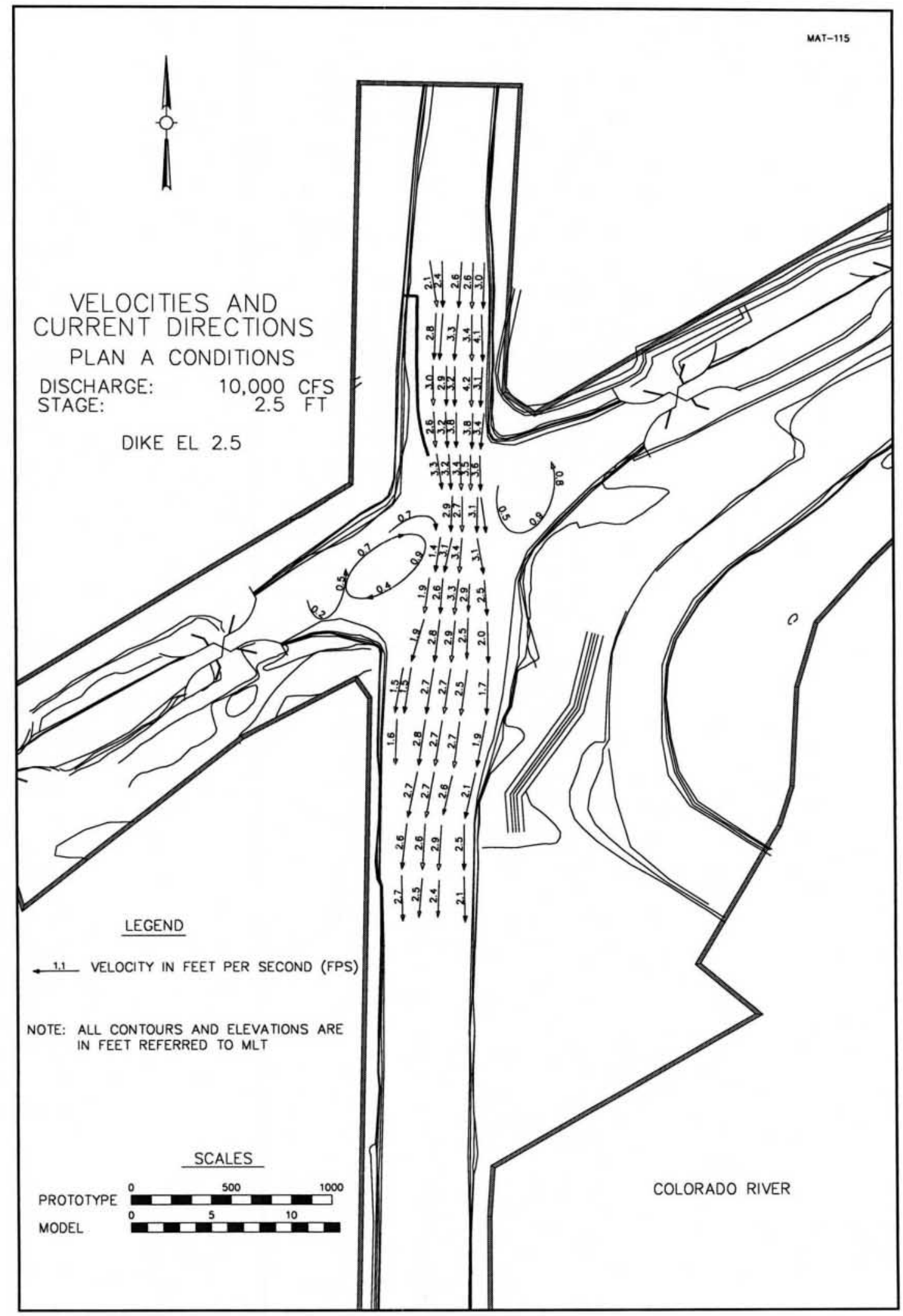

Plate 21 


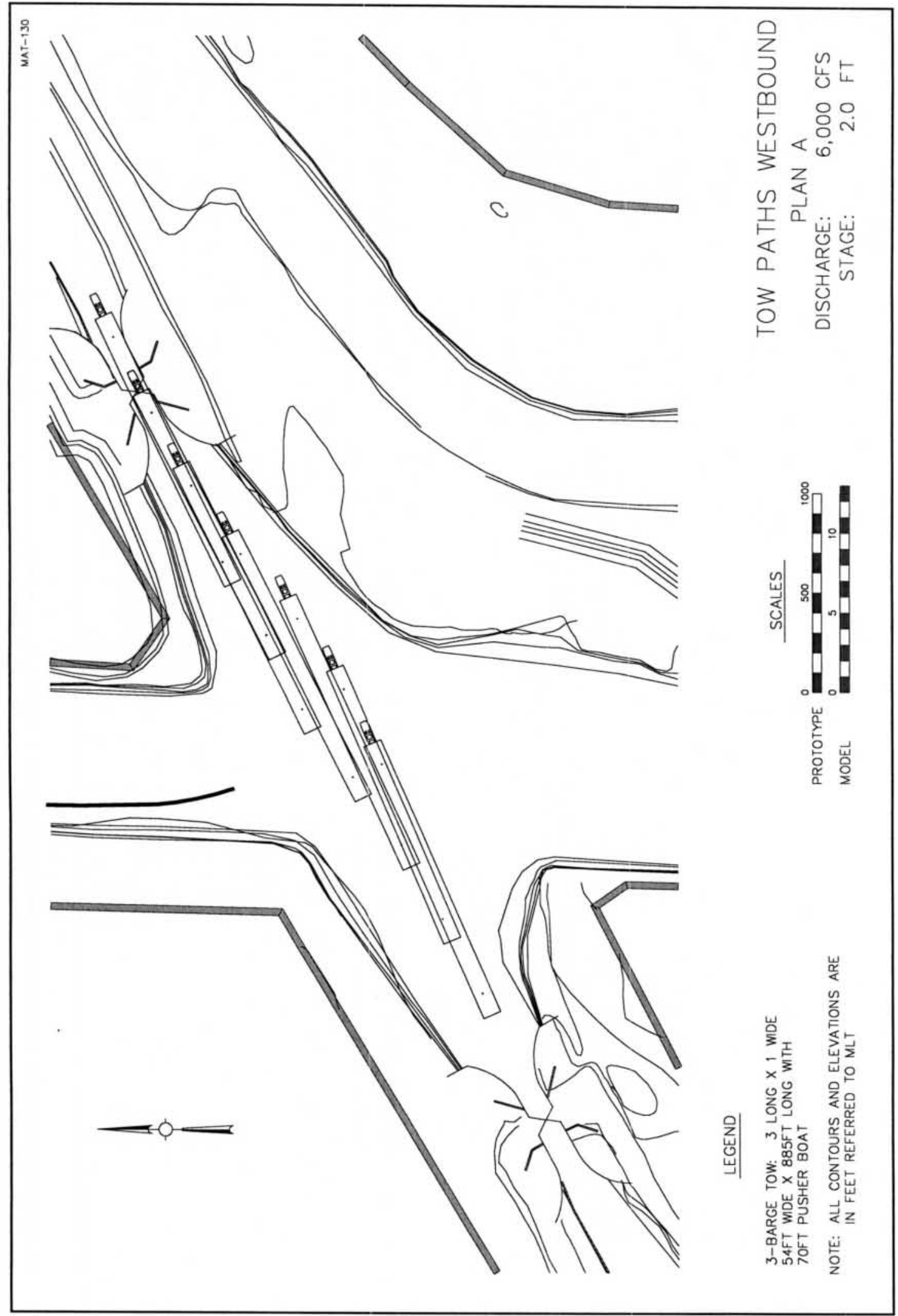

Plate 22 


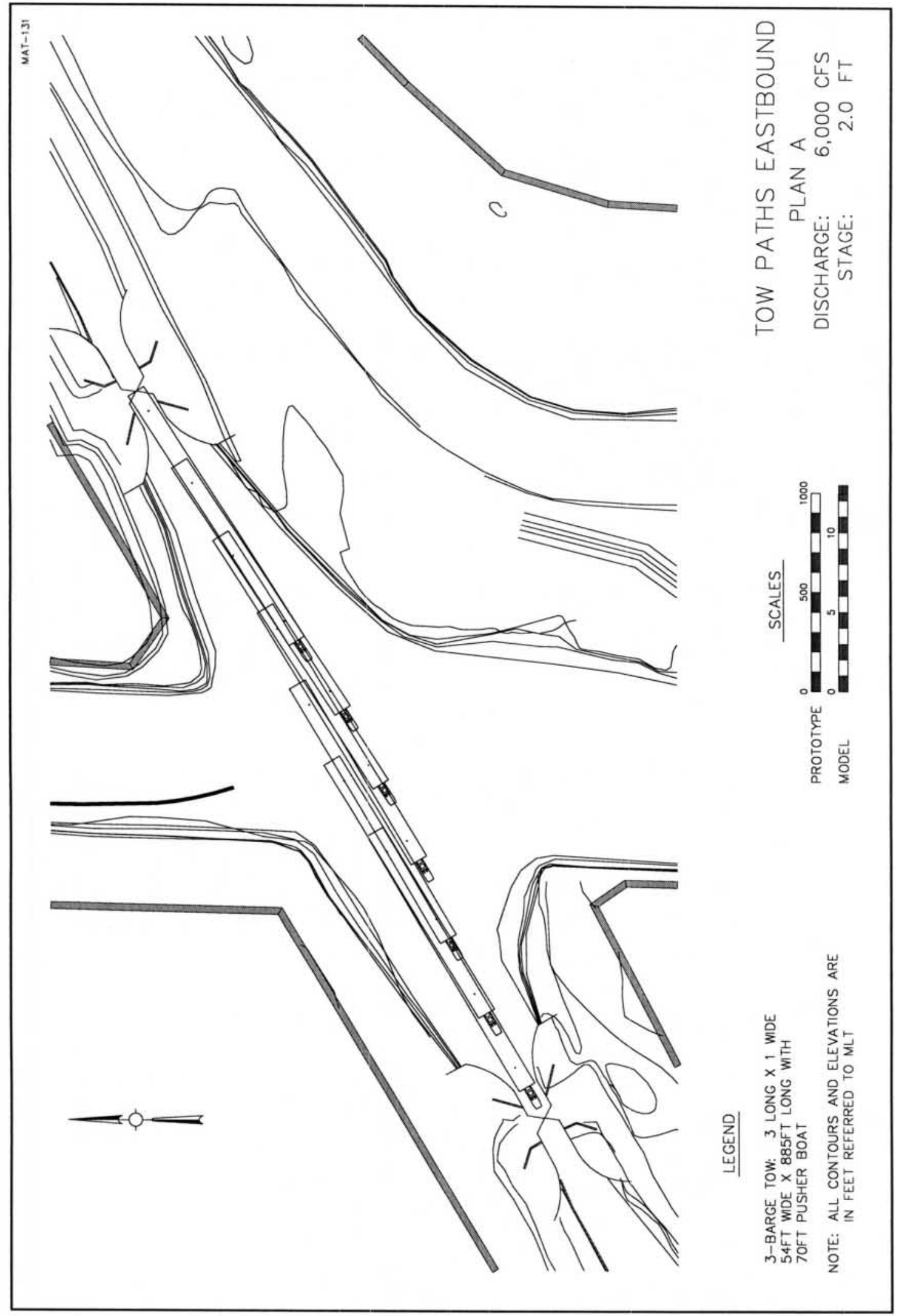

Plate 23 


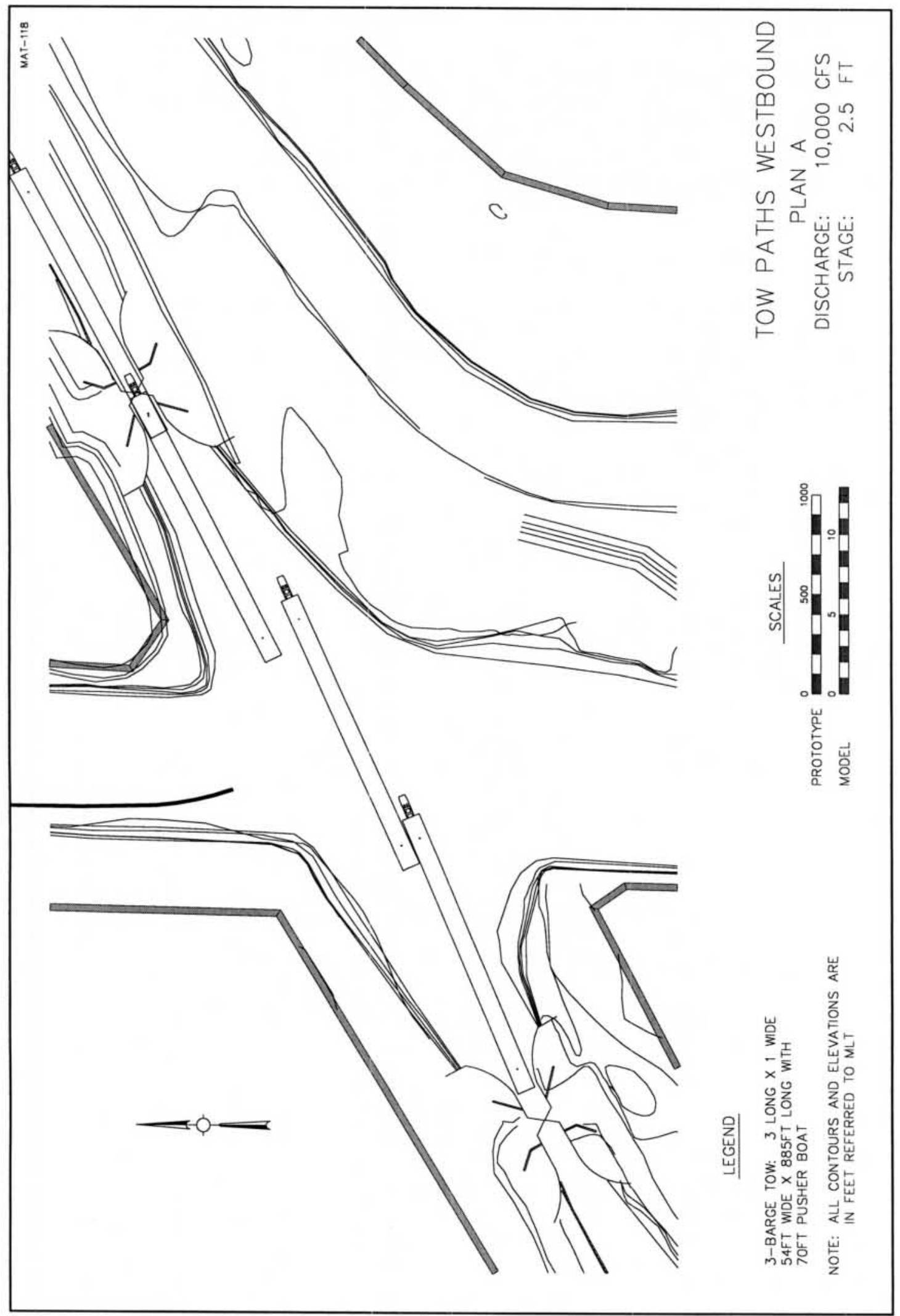

Plate 24 


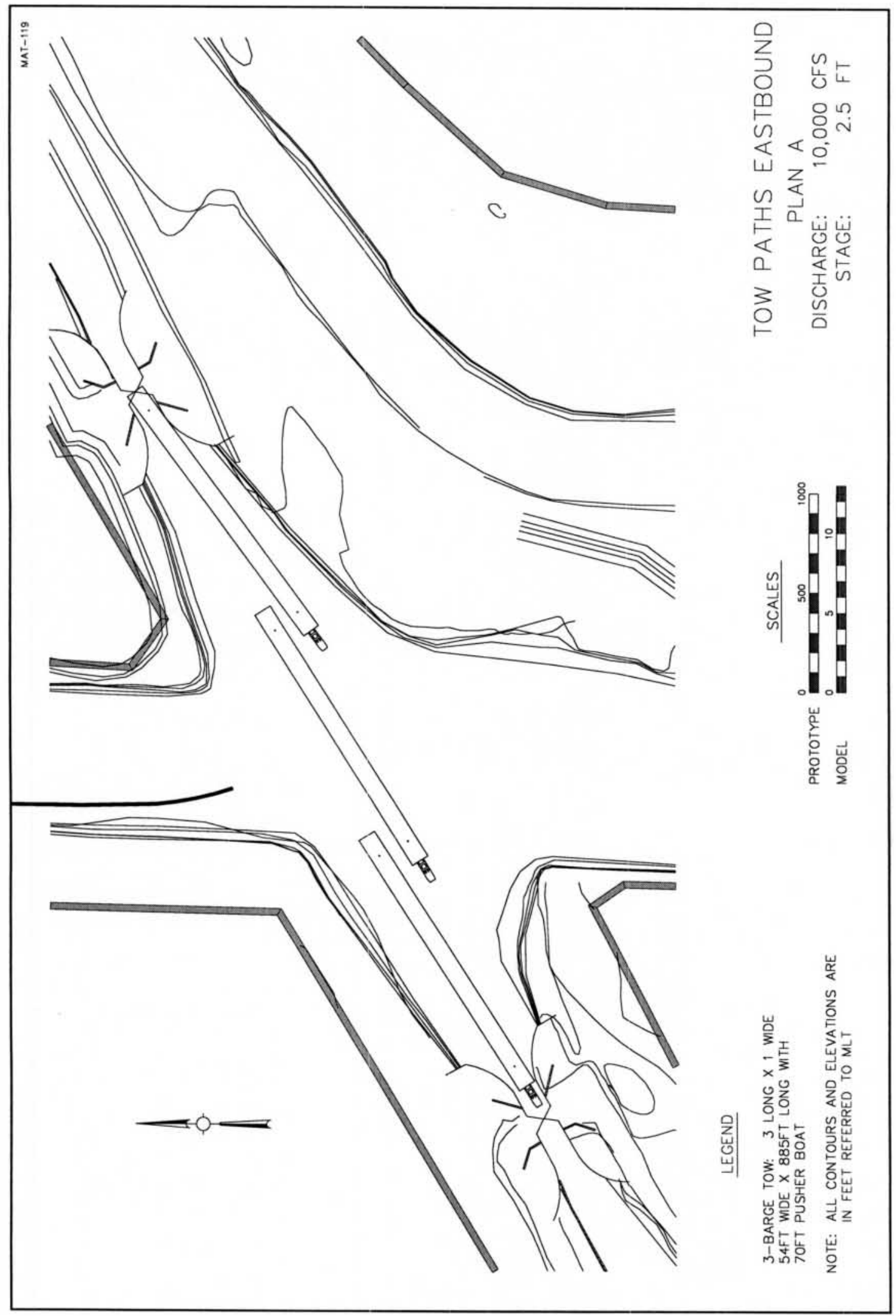

Plate 25 


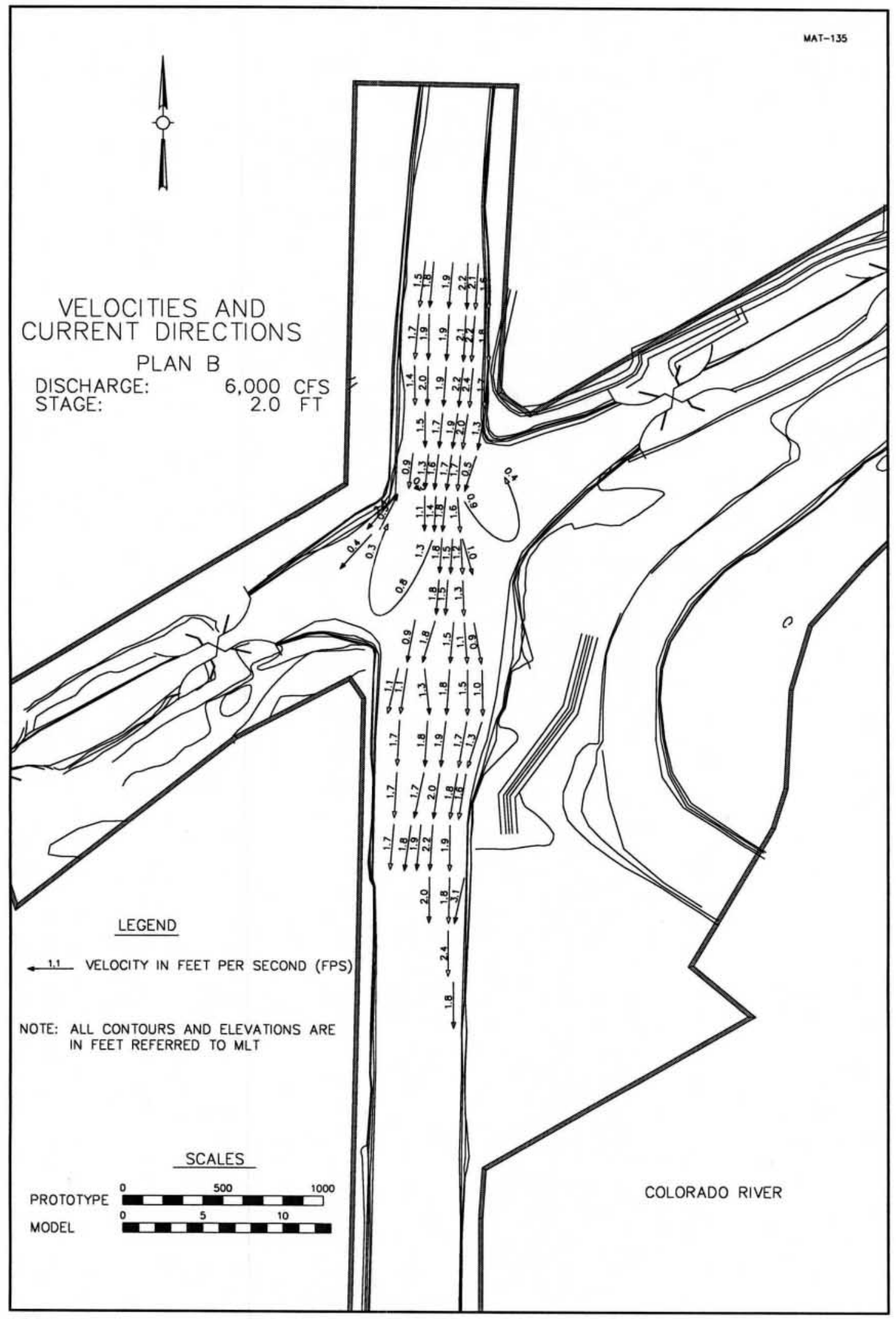

Plate 26 


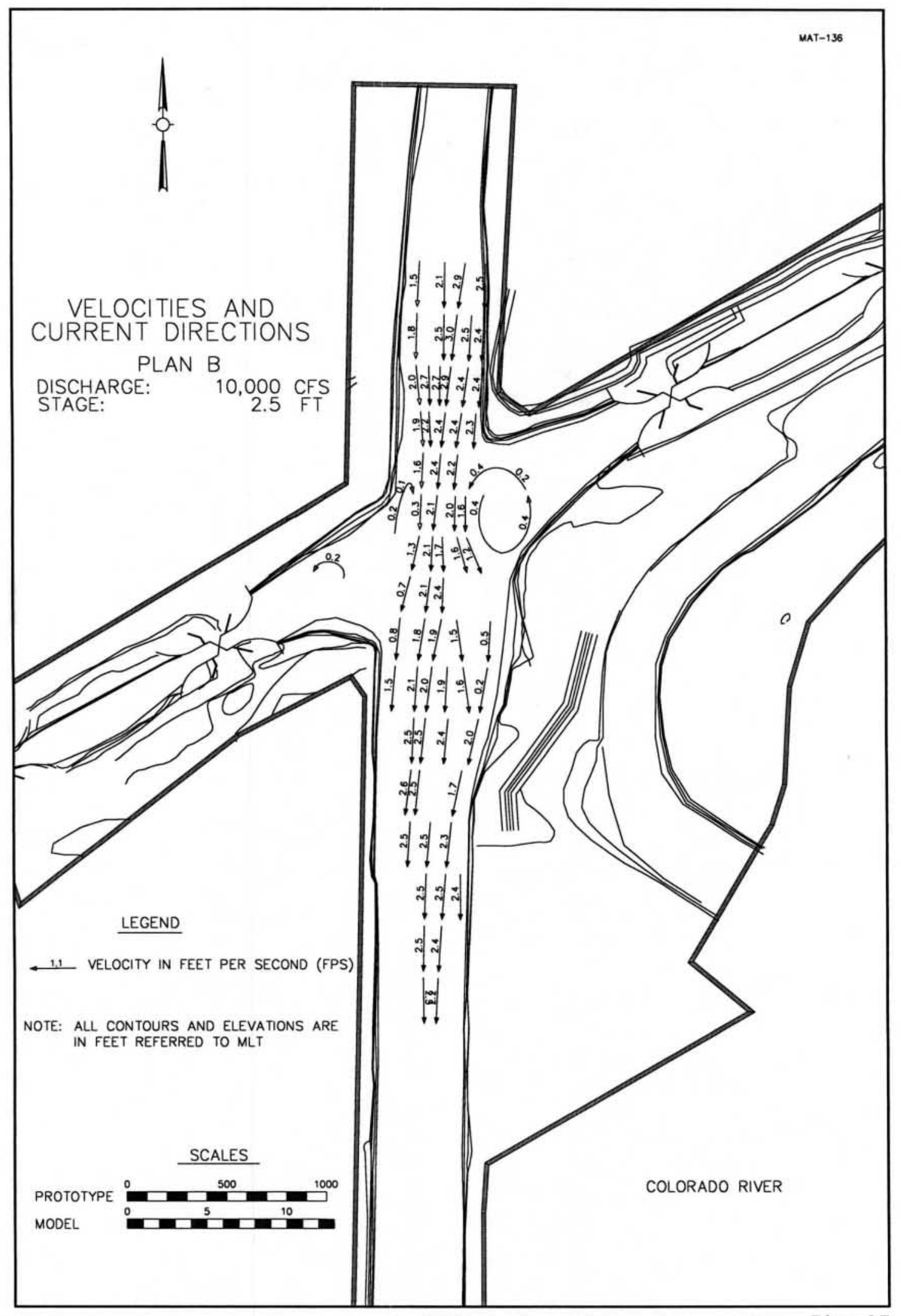

Plate 27 


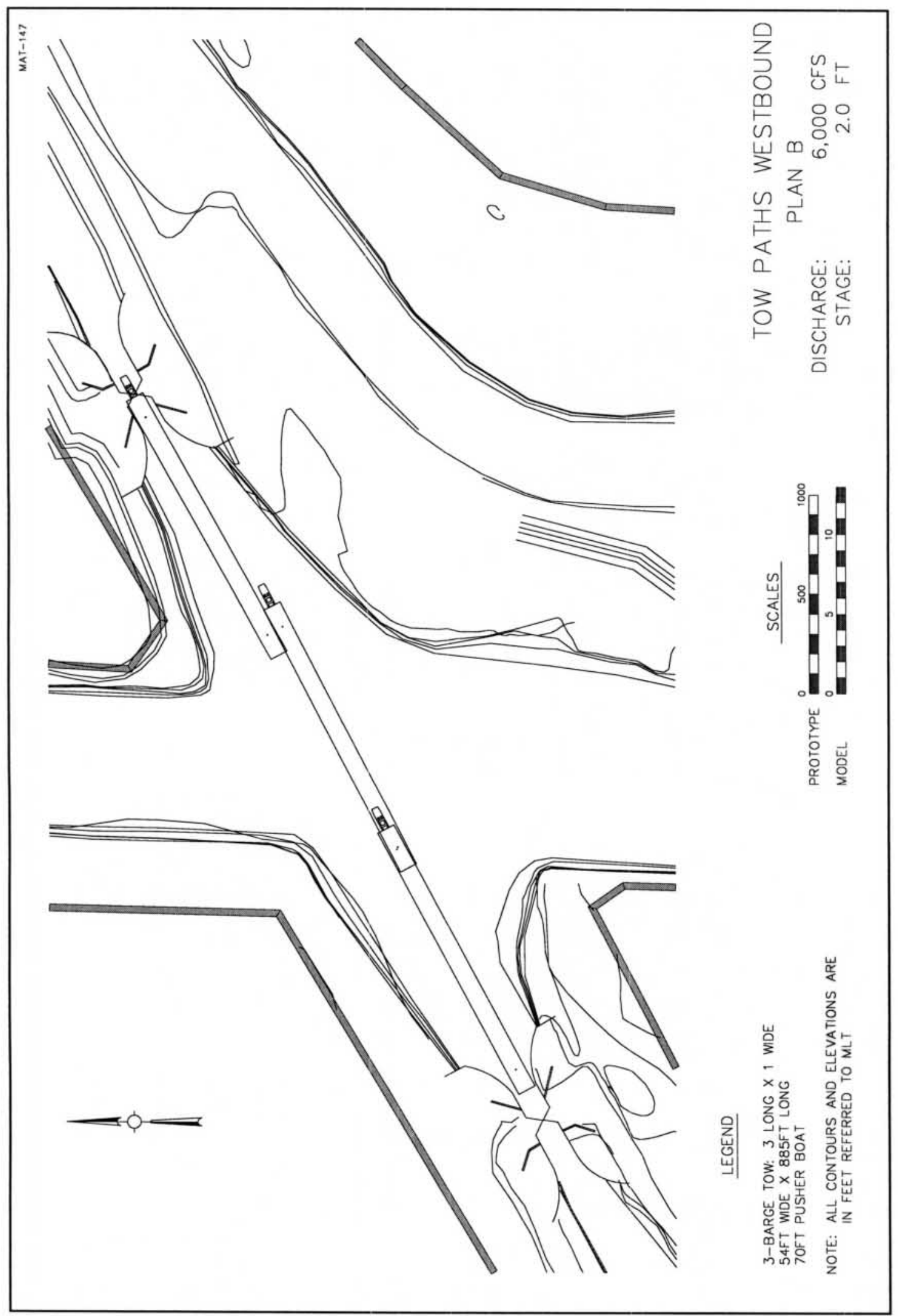

Plate 28 


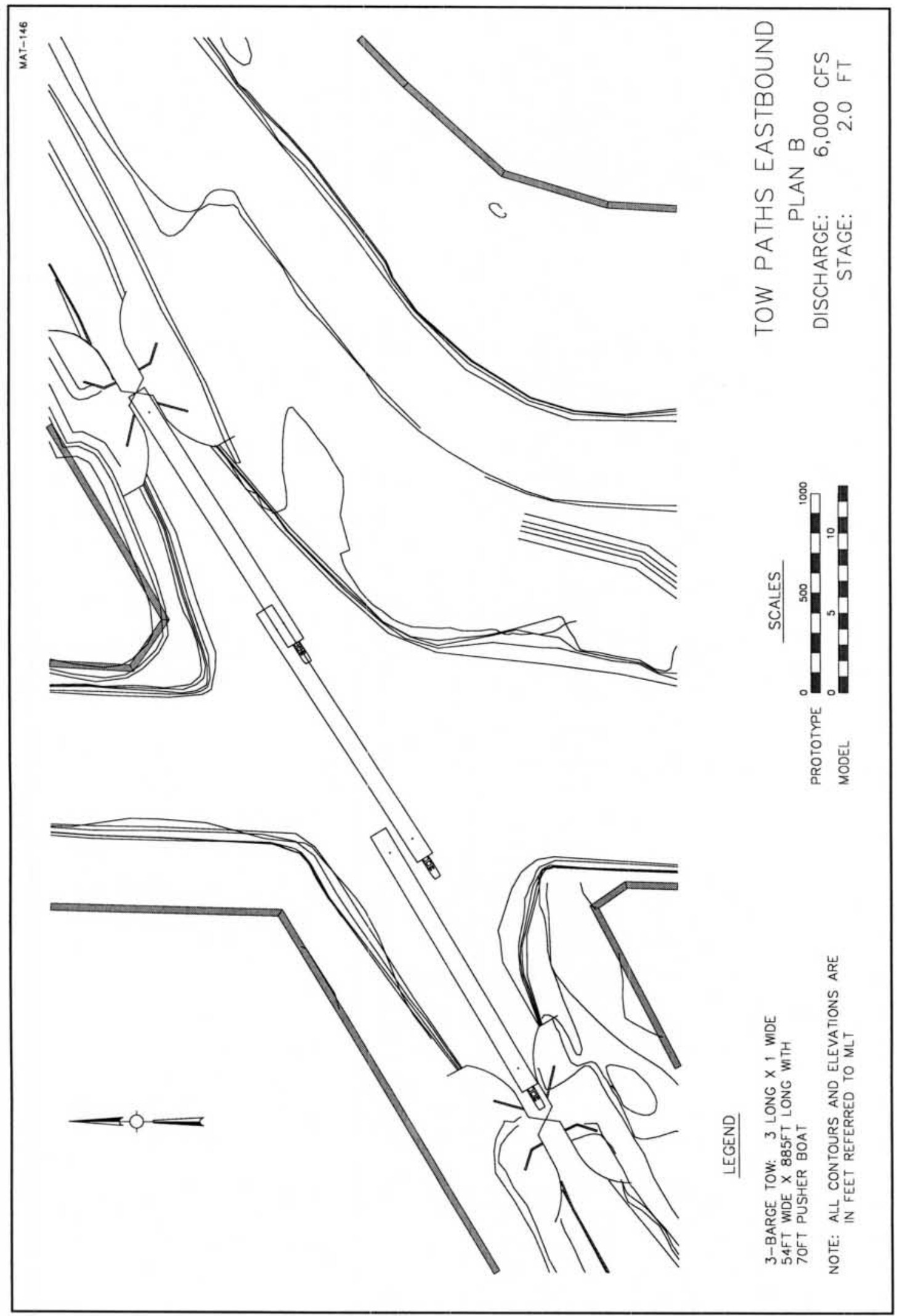

Plate 29 


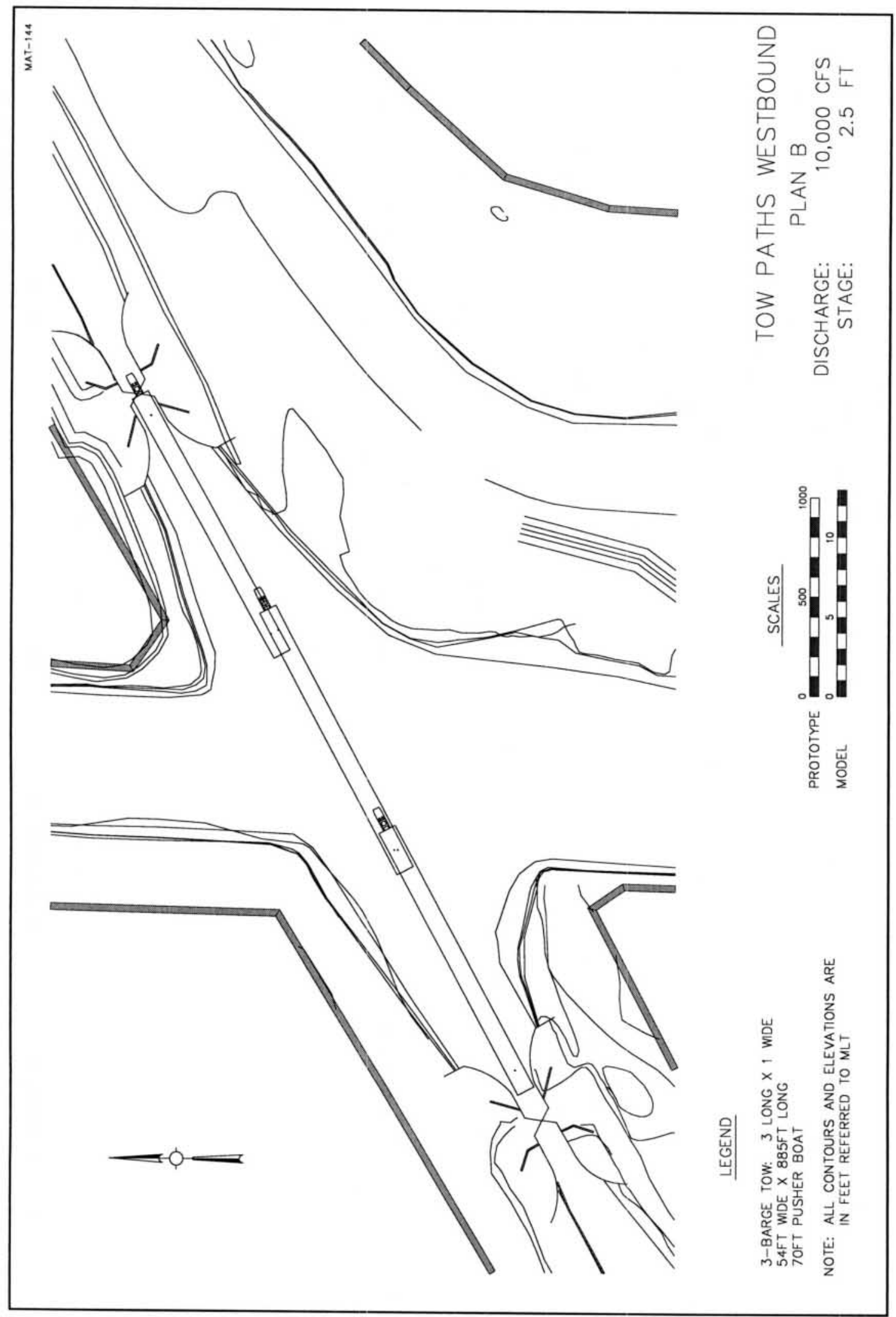

Plate 30 


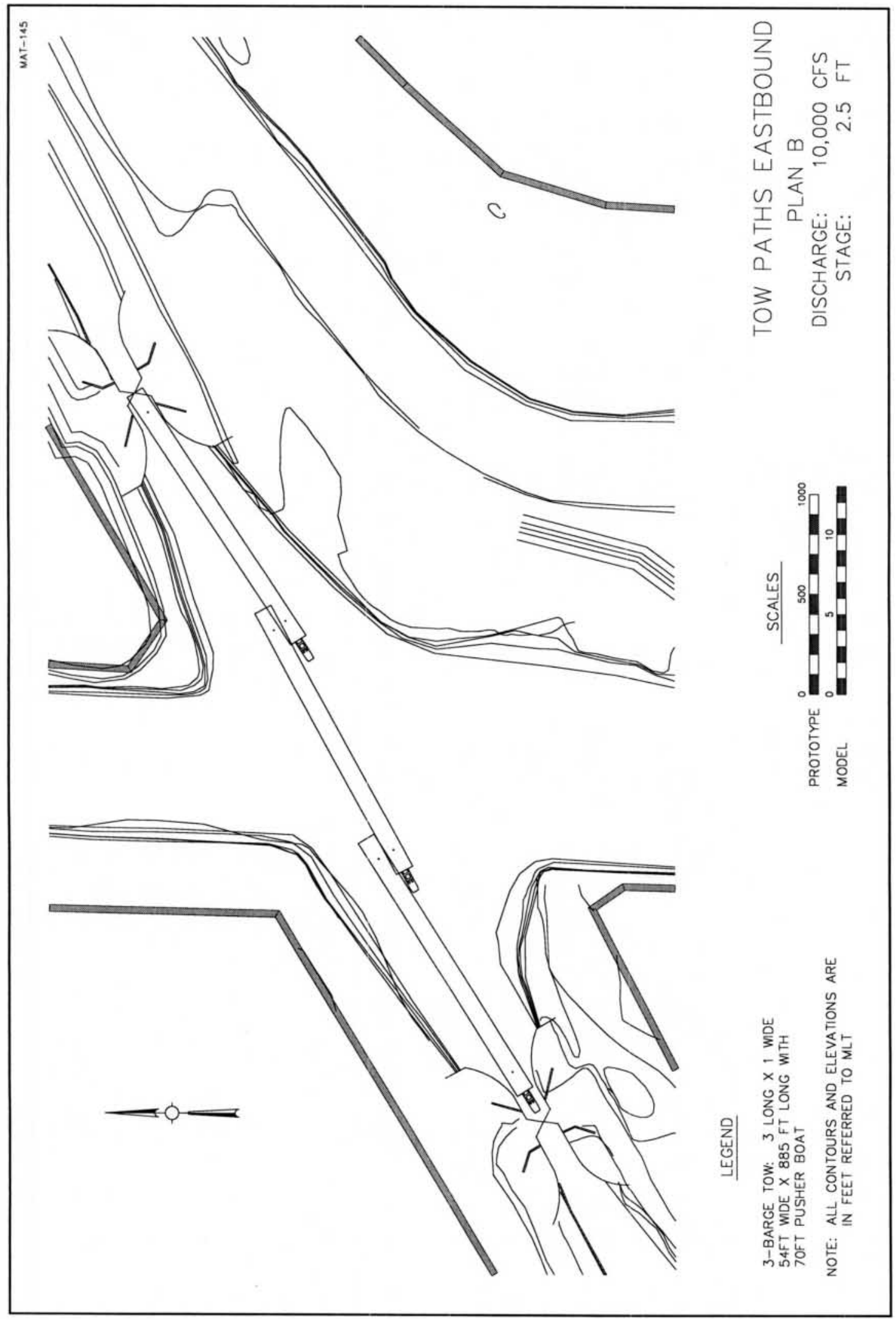

Plate 31 


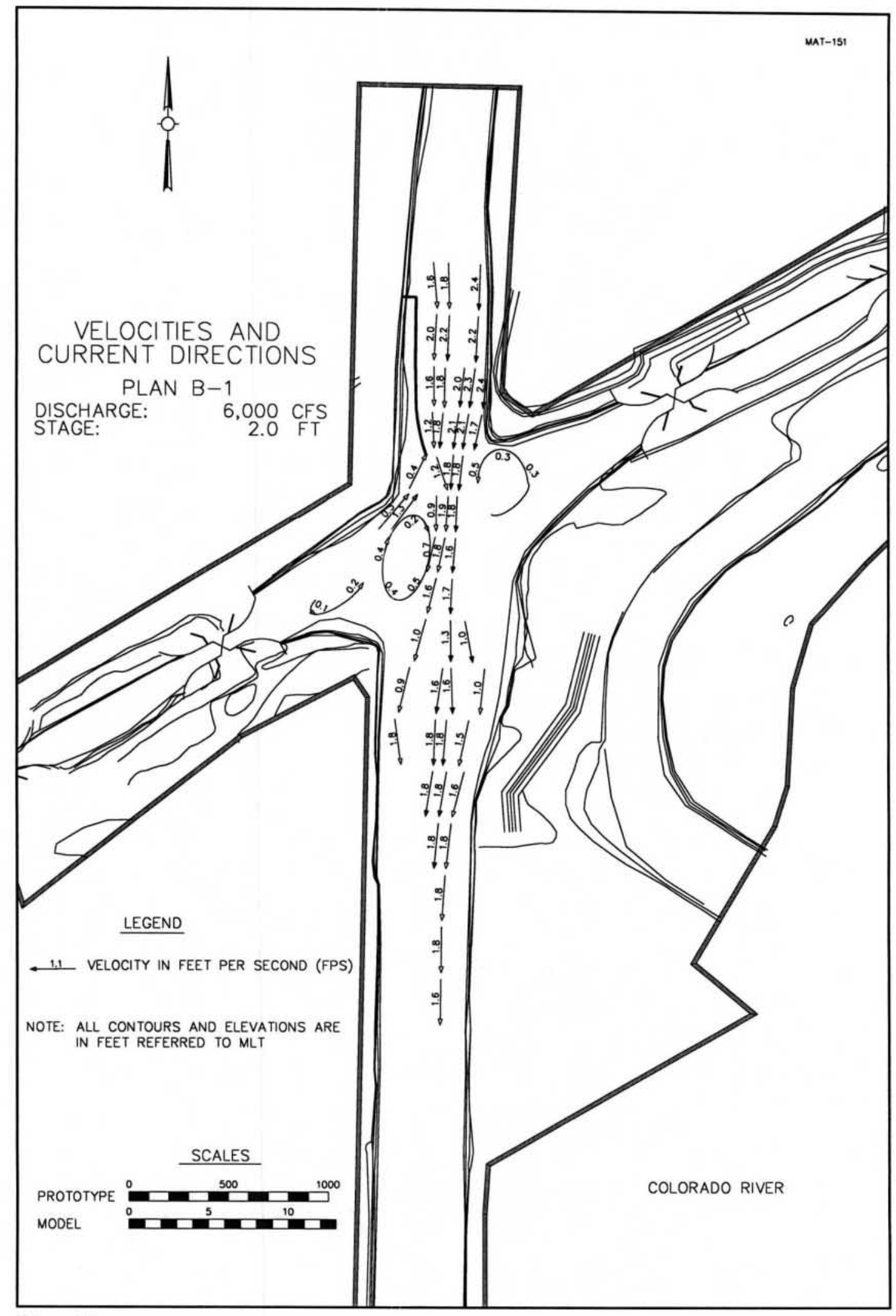

Plate 32 


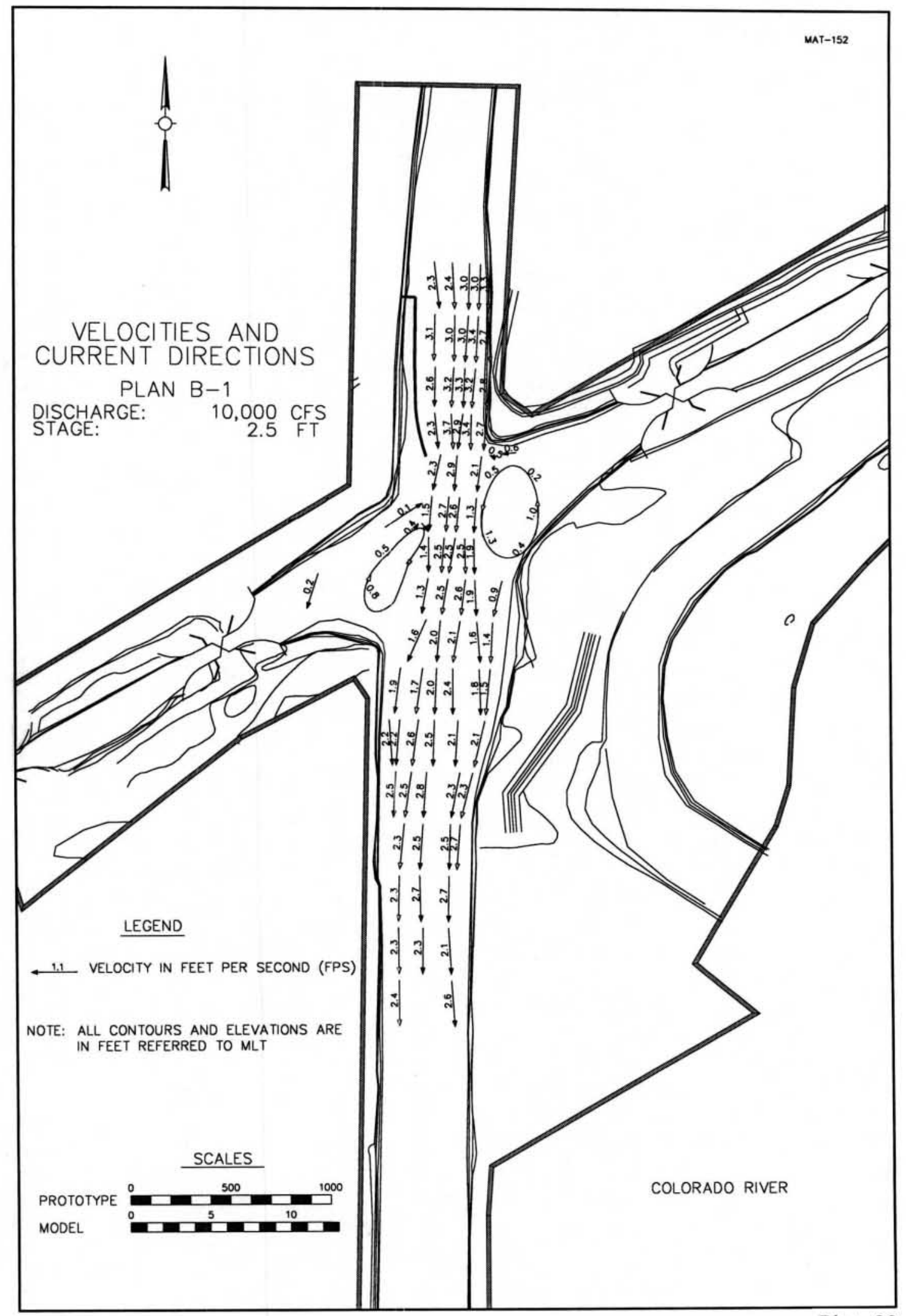

Plate 33 


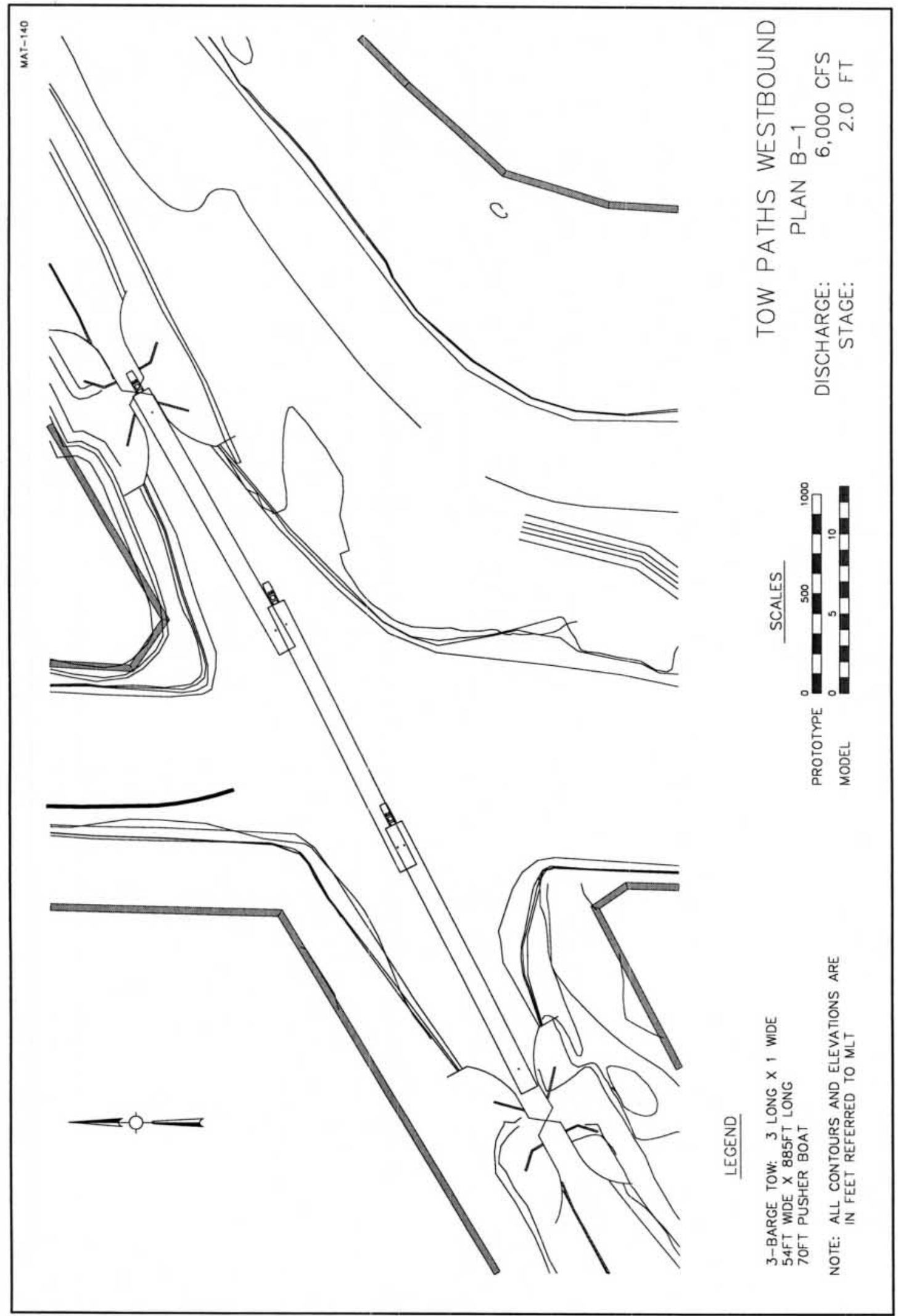

Plate 34 


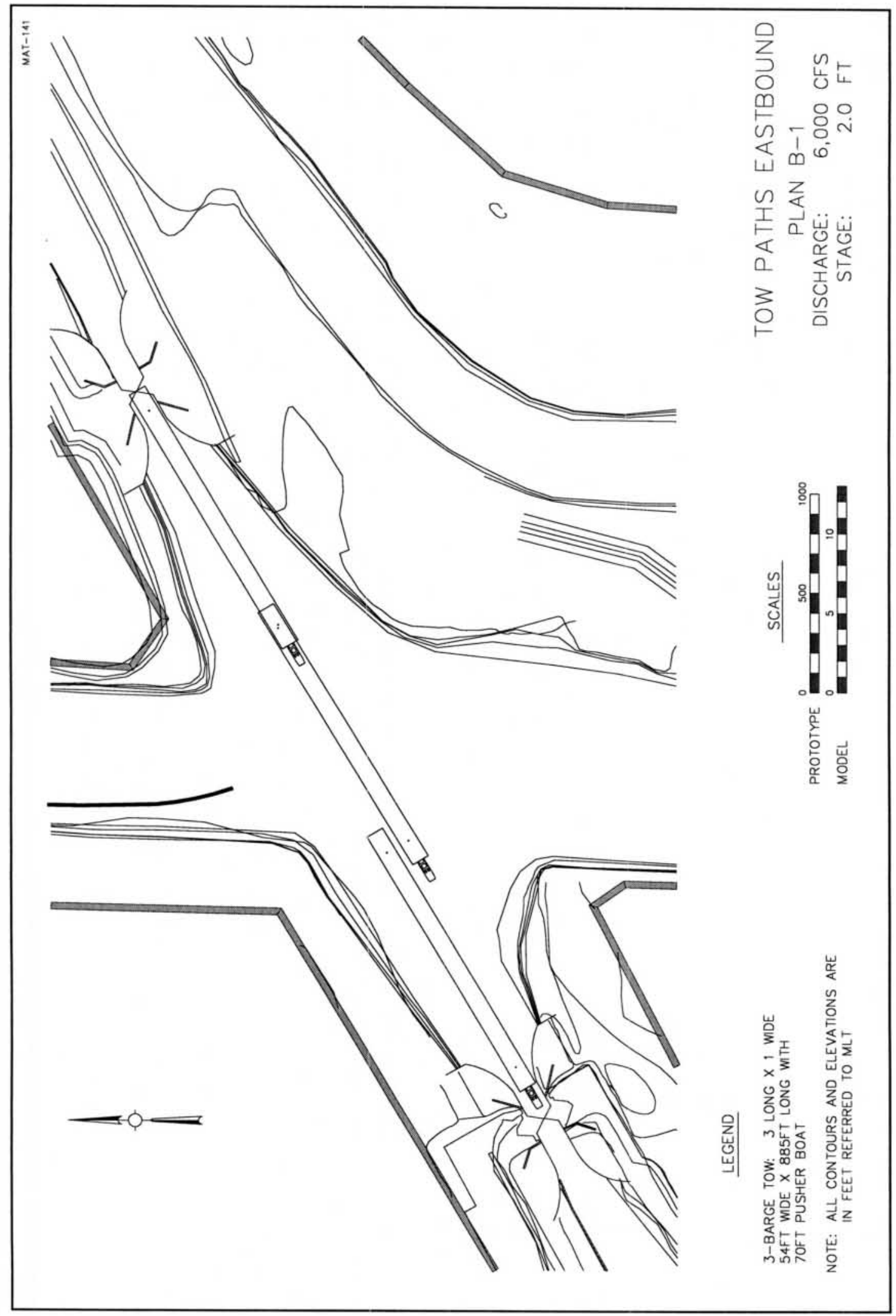

Plate 35 


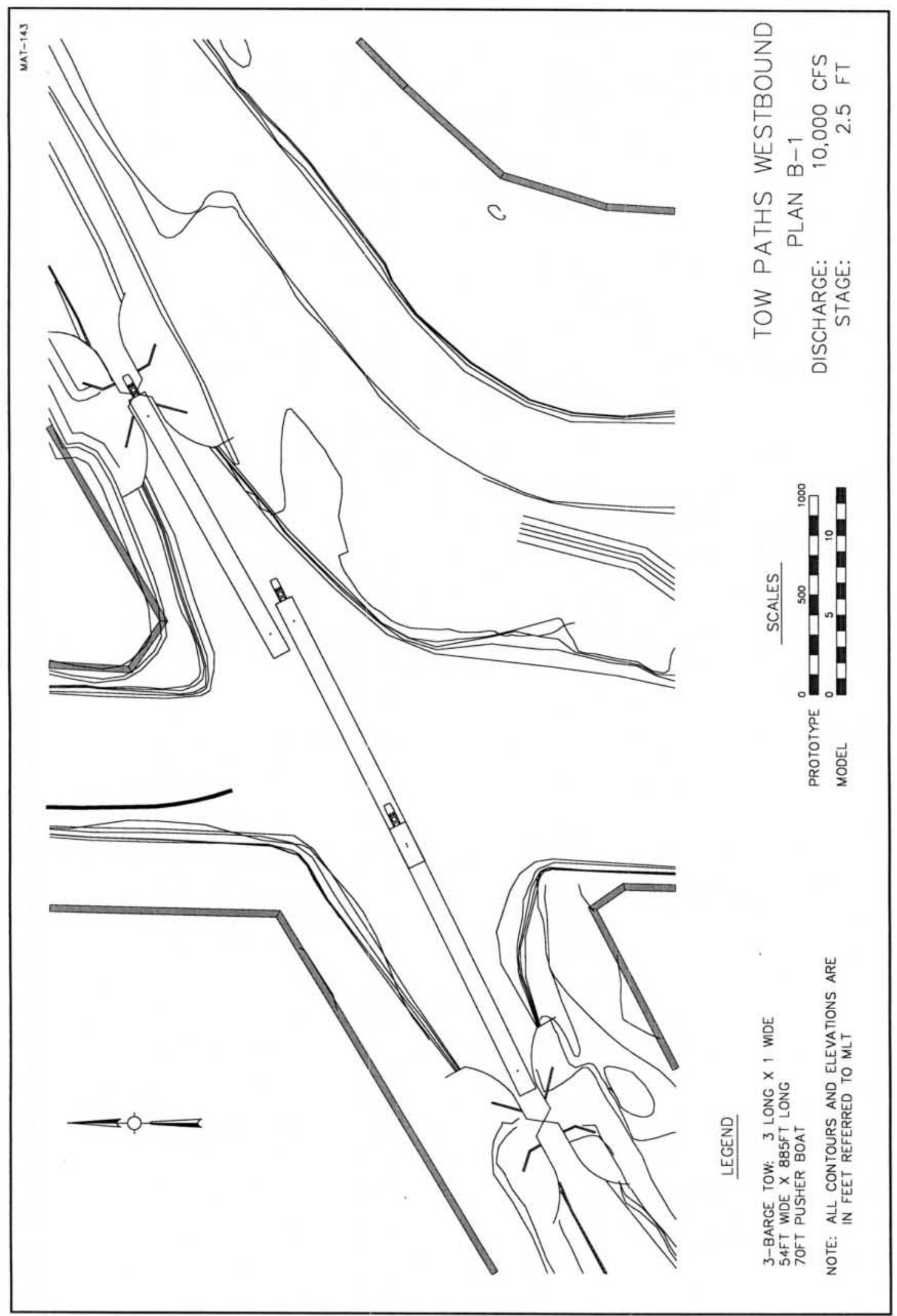

Plate 36 


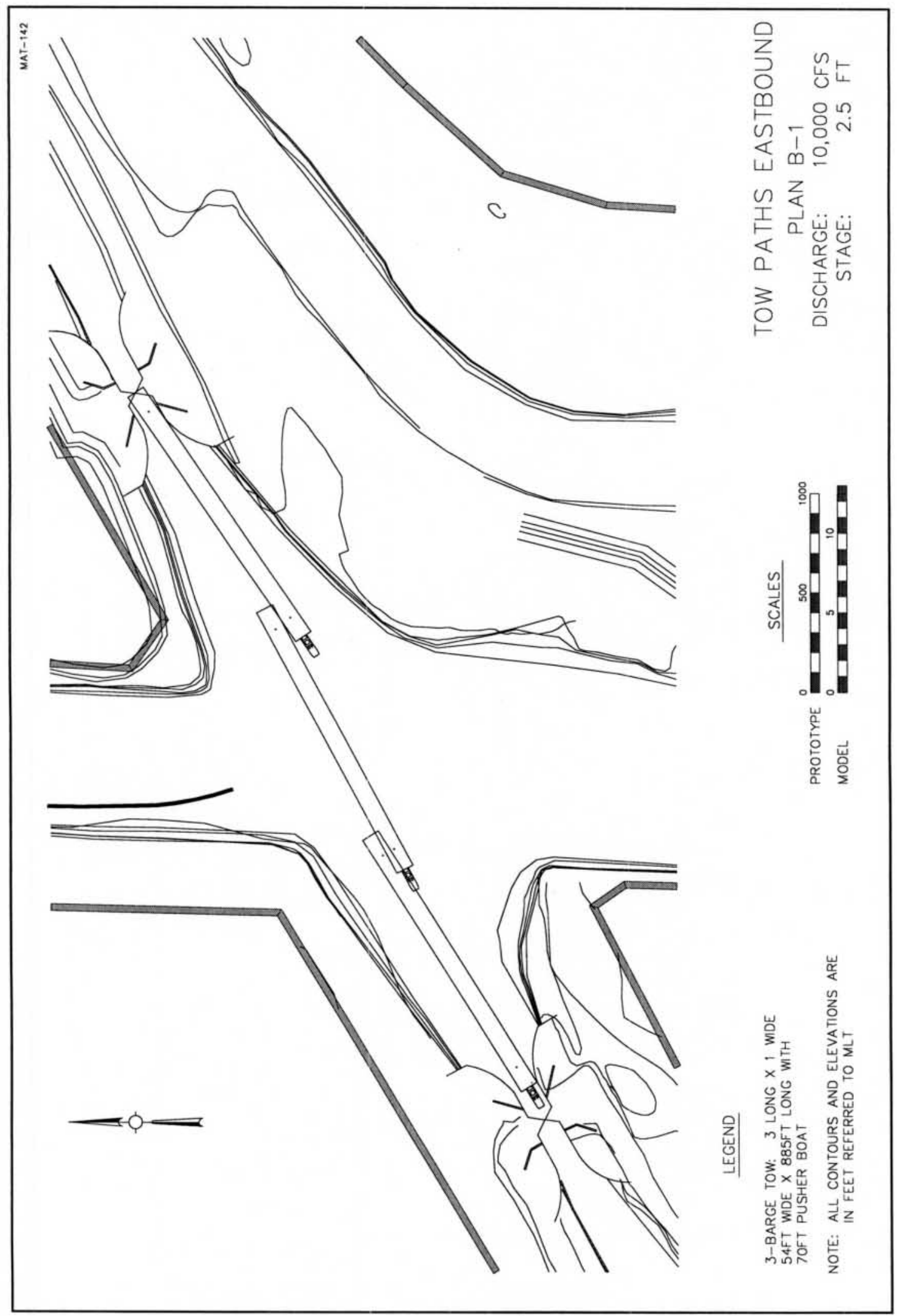

Plate 37 


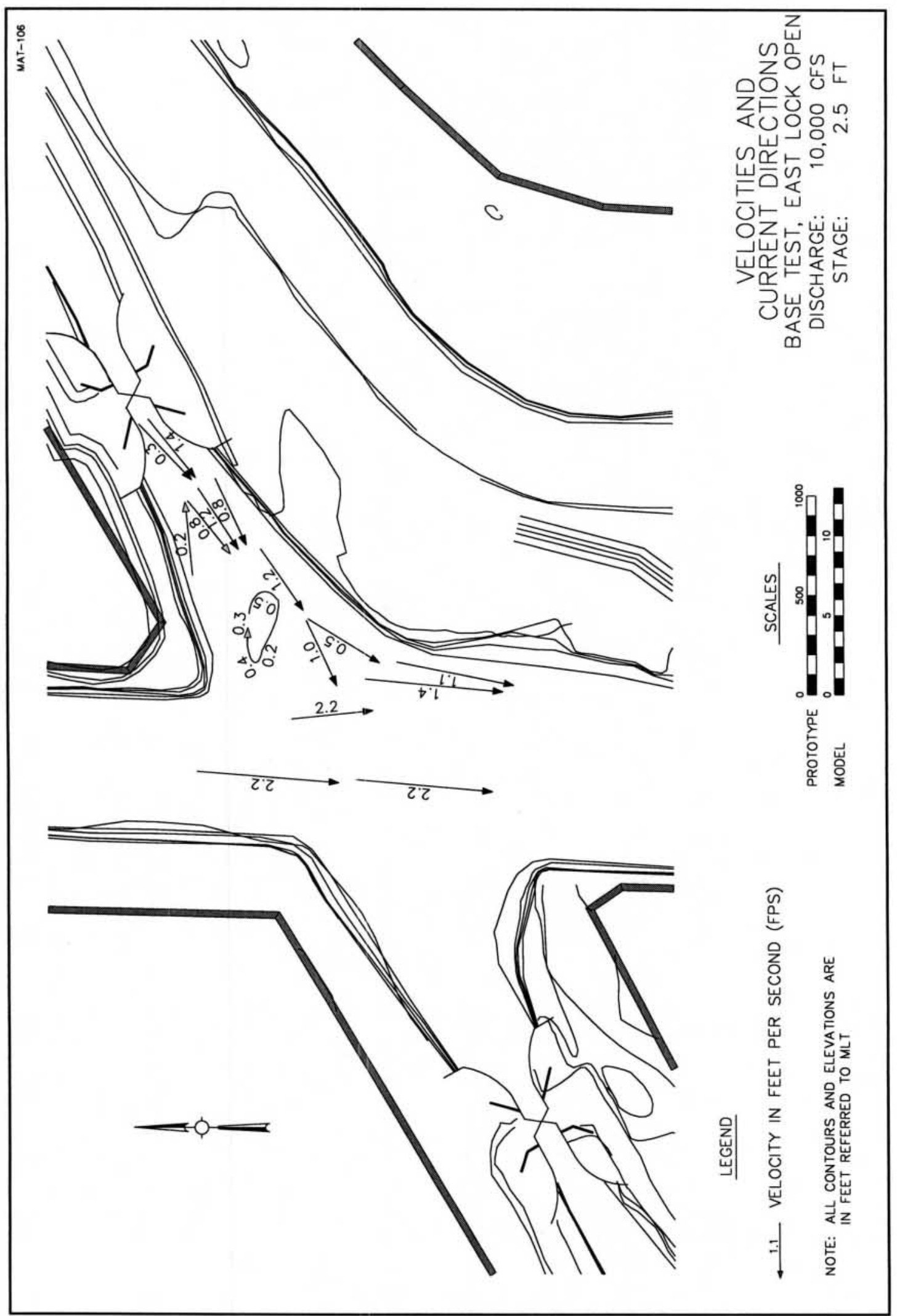

Plate 38 


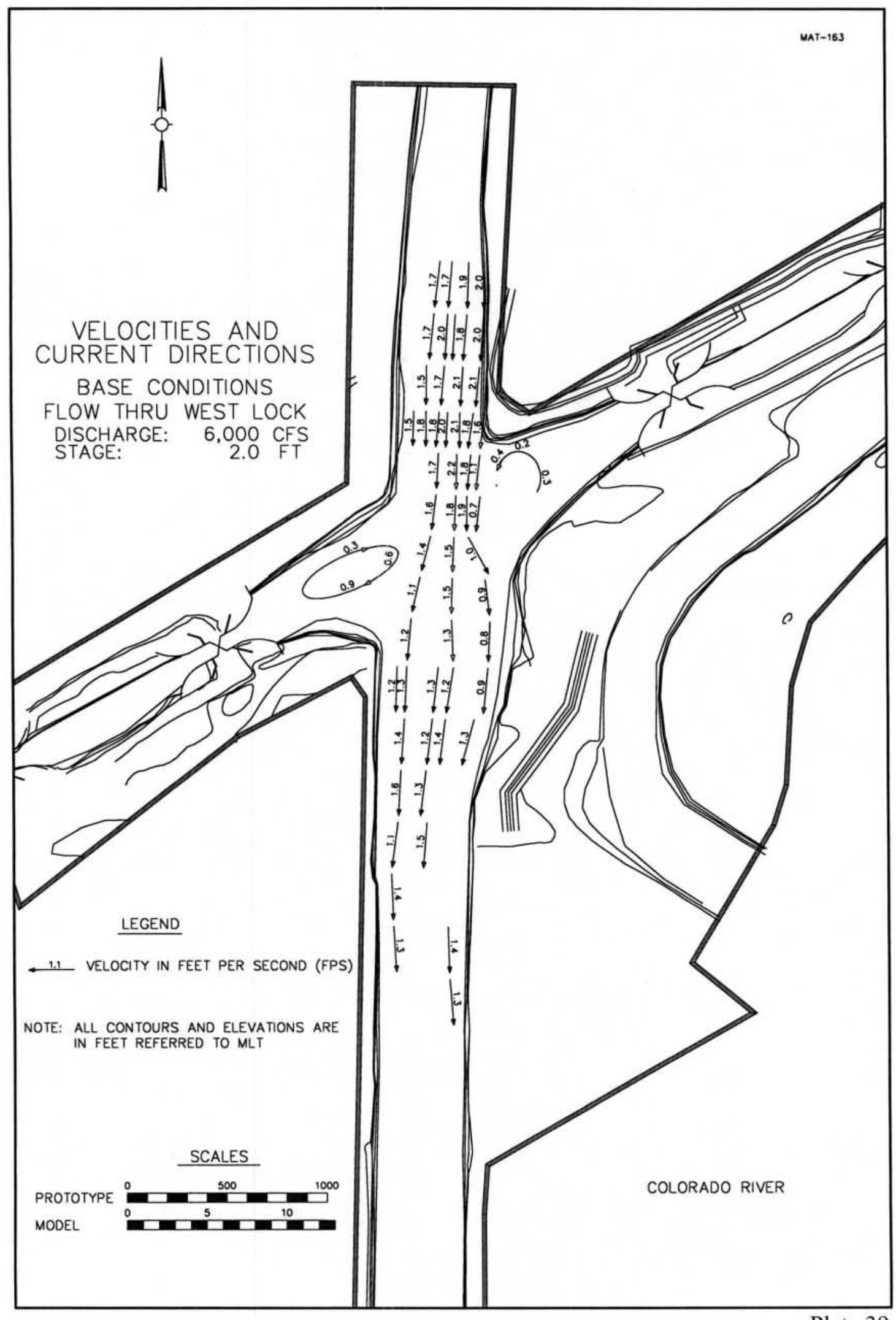

Plate 39 


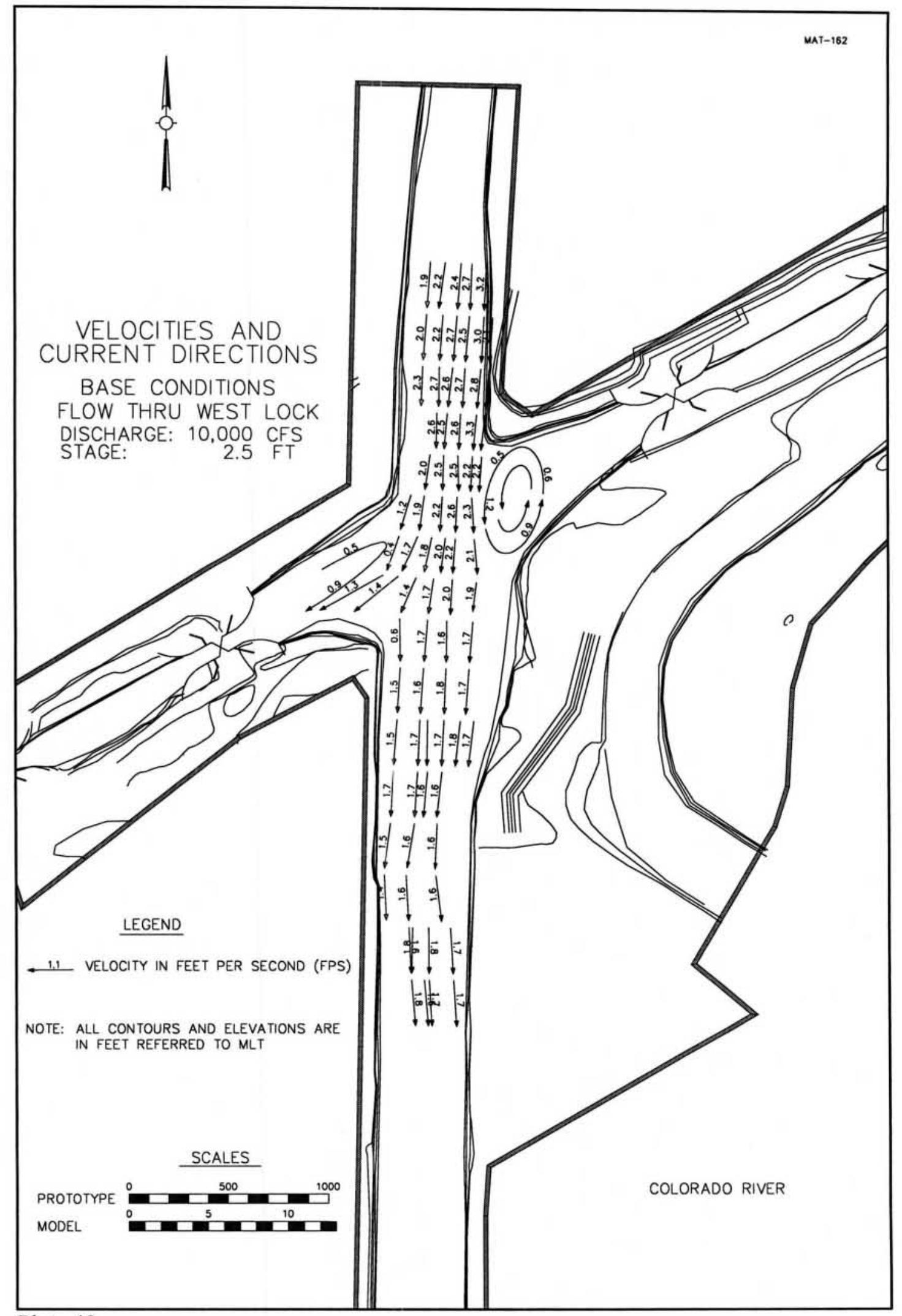

Plate 40 


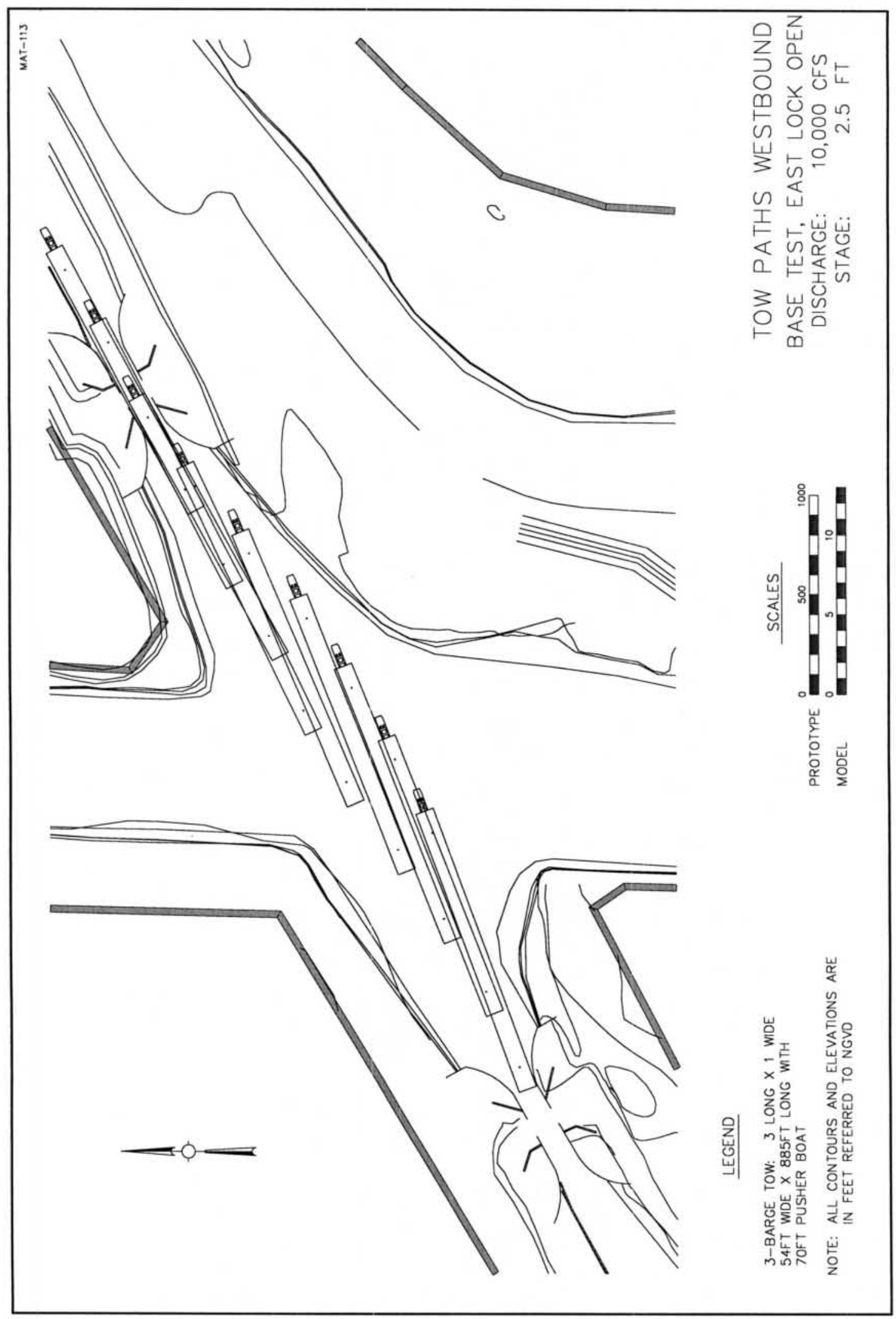

Plate 41 


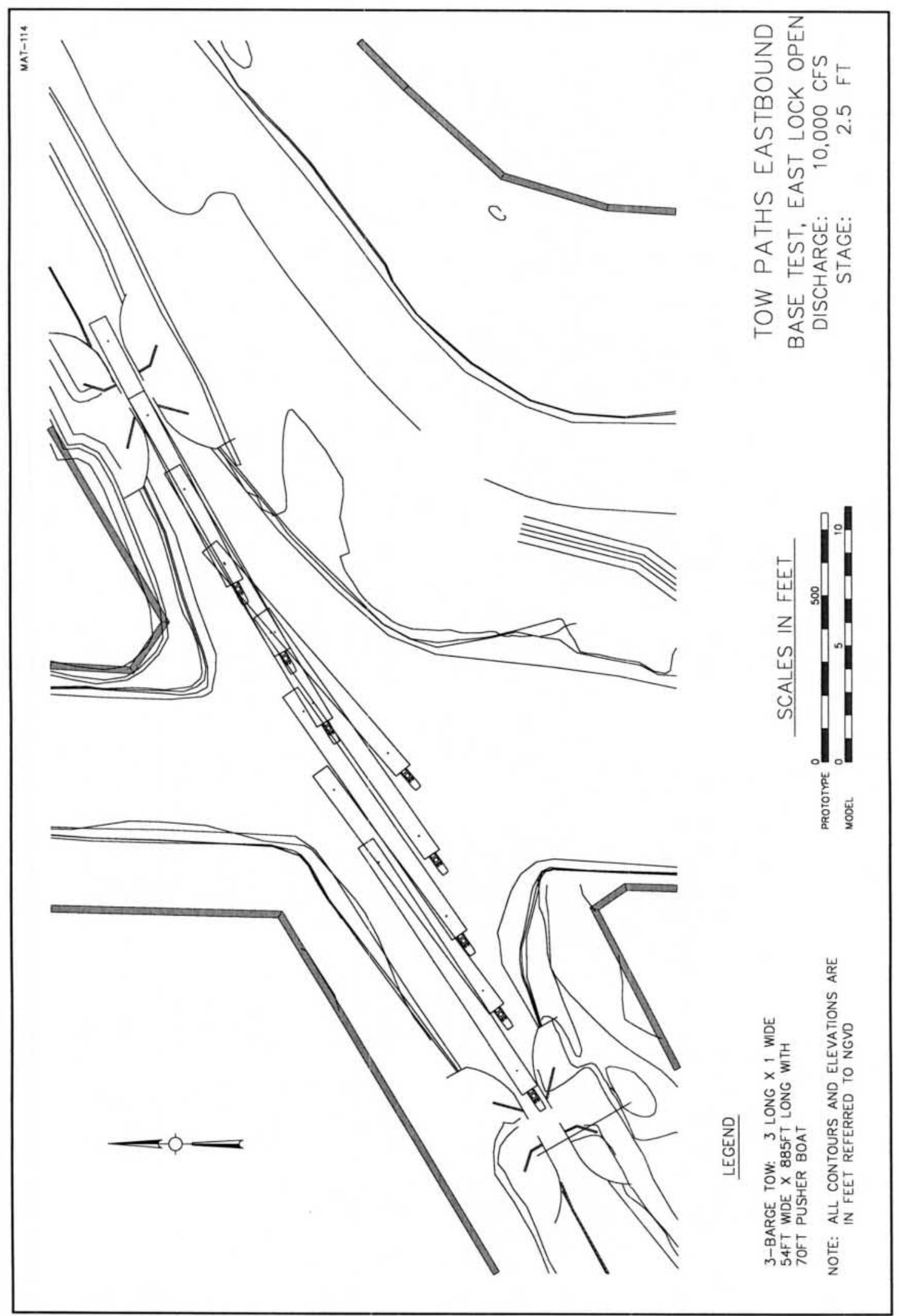

Plate 42 


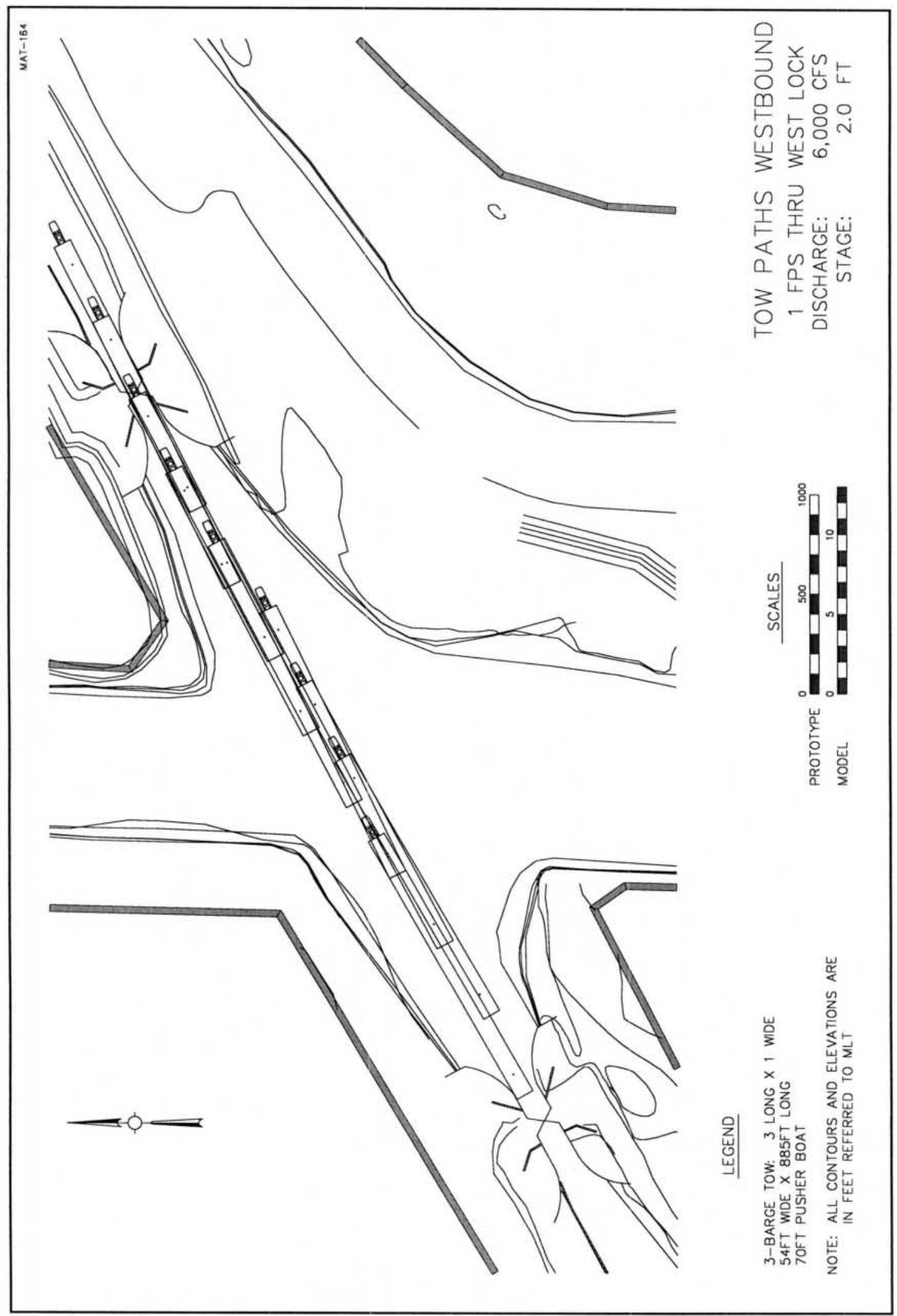

Plate 43 


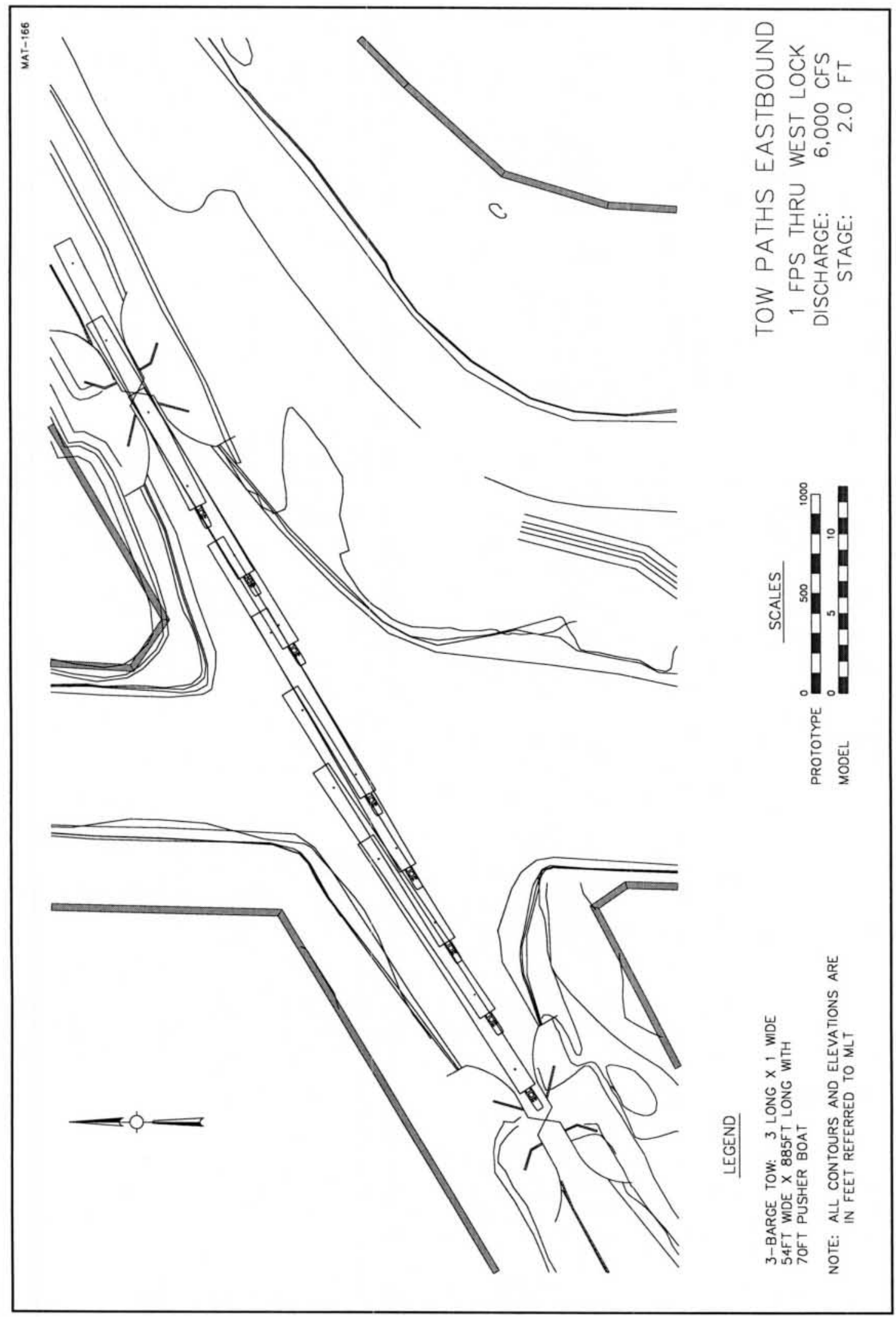

Plate 44 


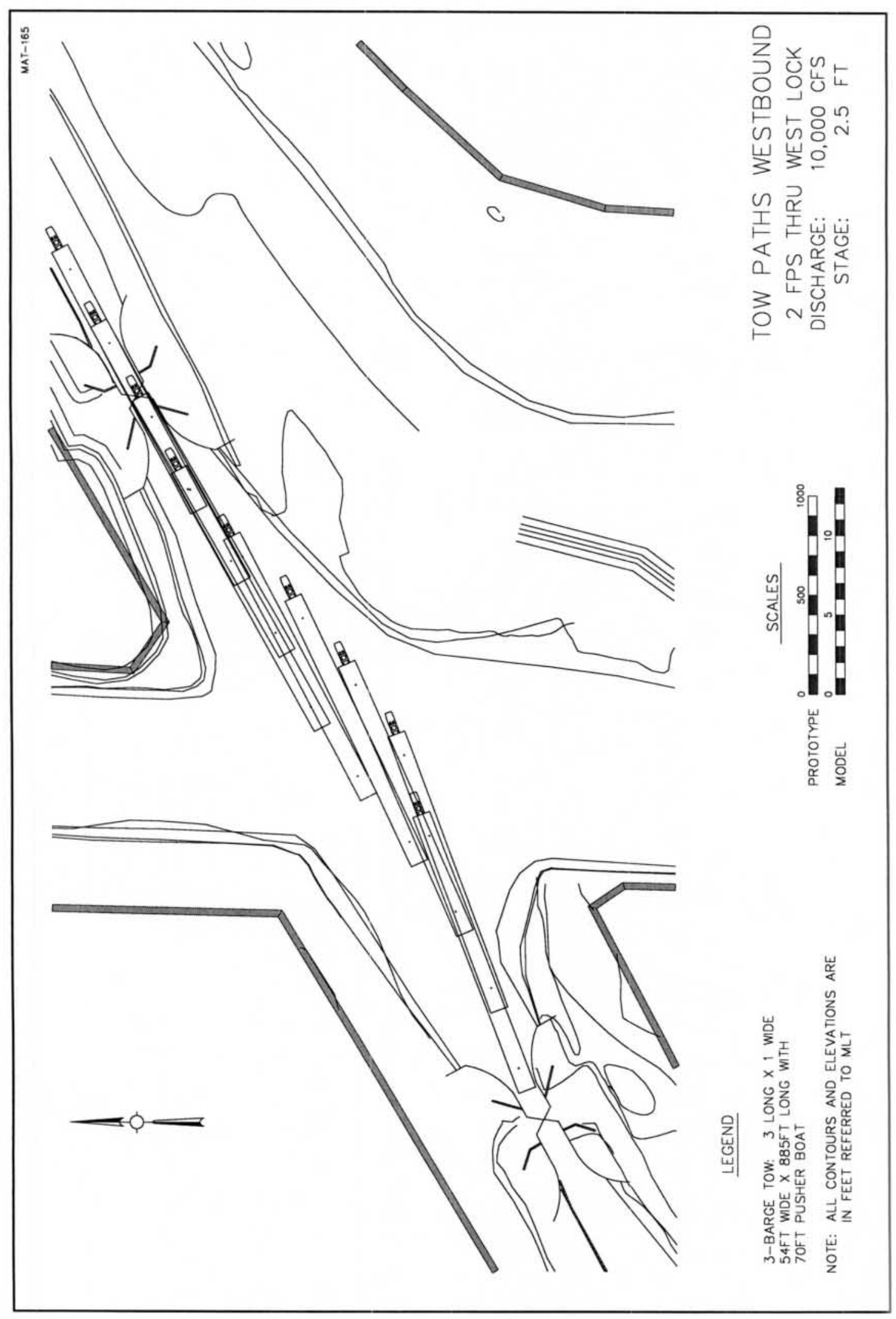

Plate 45 


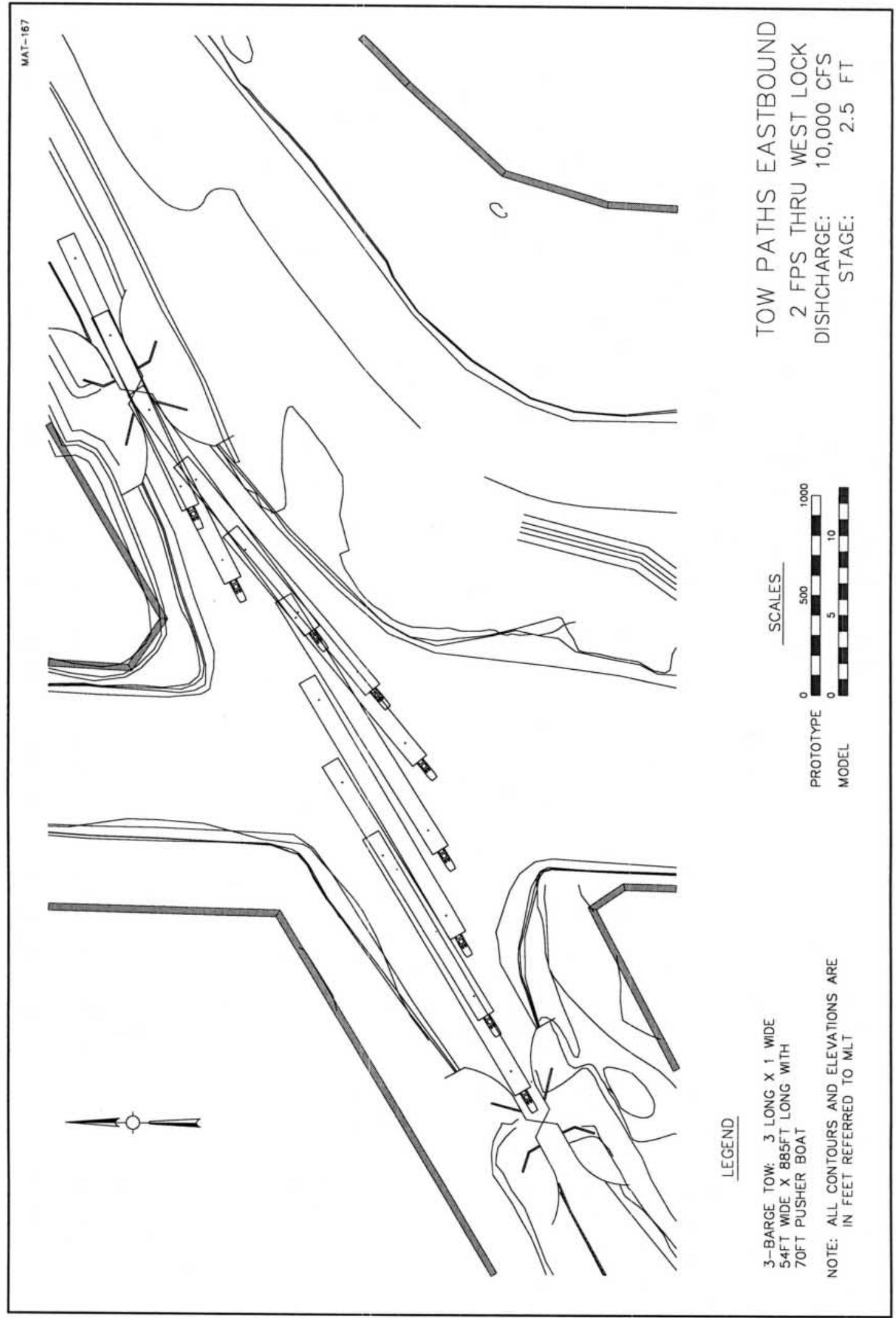

Plate 46 


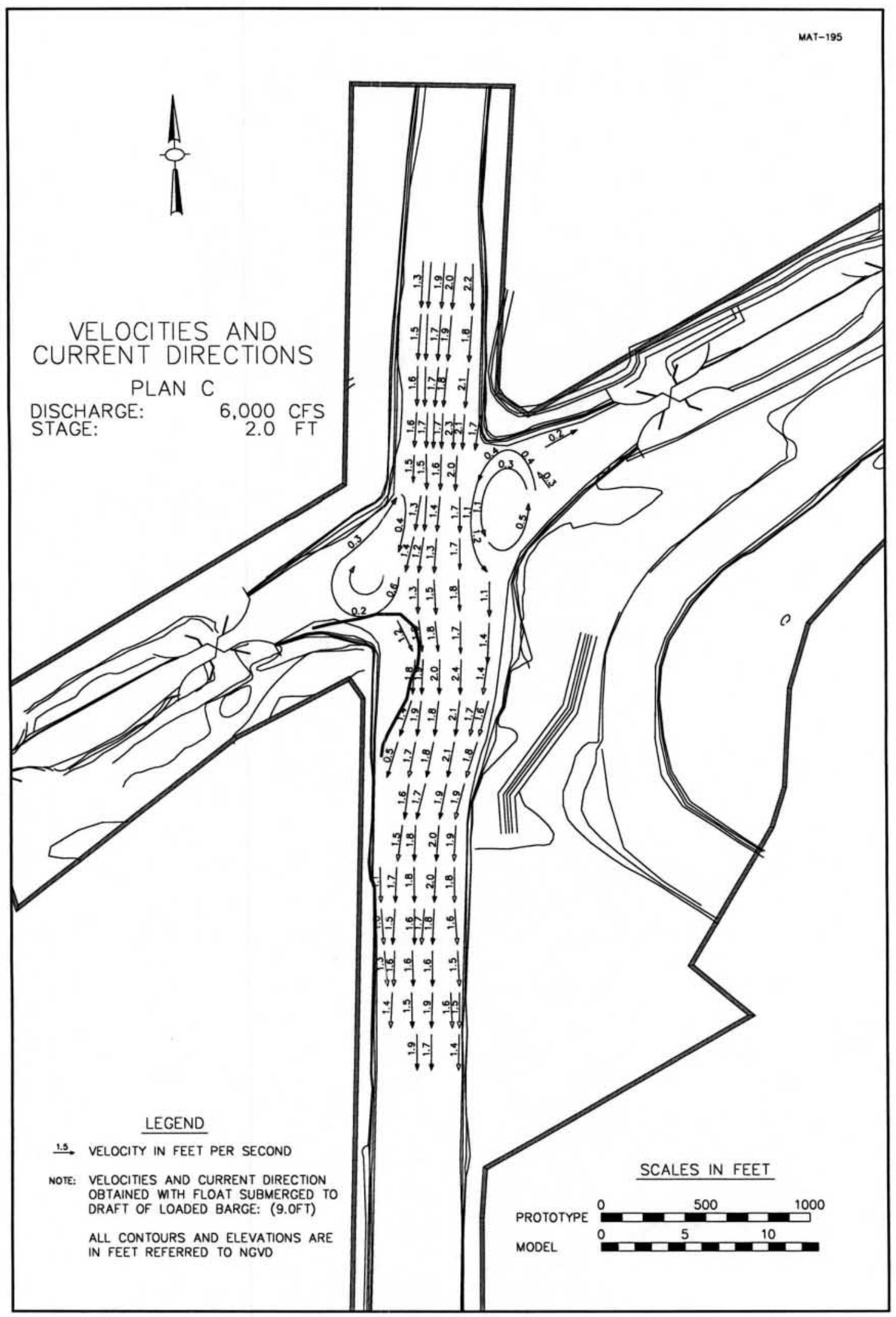

Plate 47 


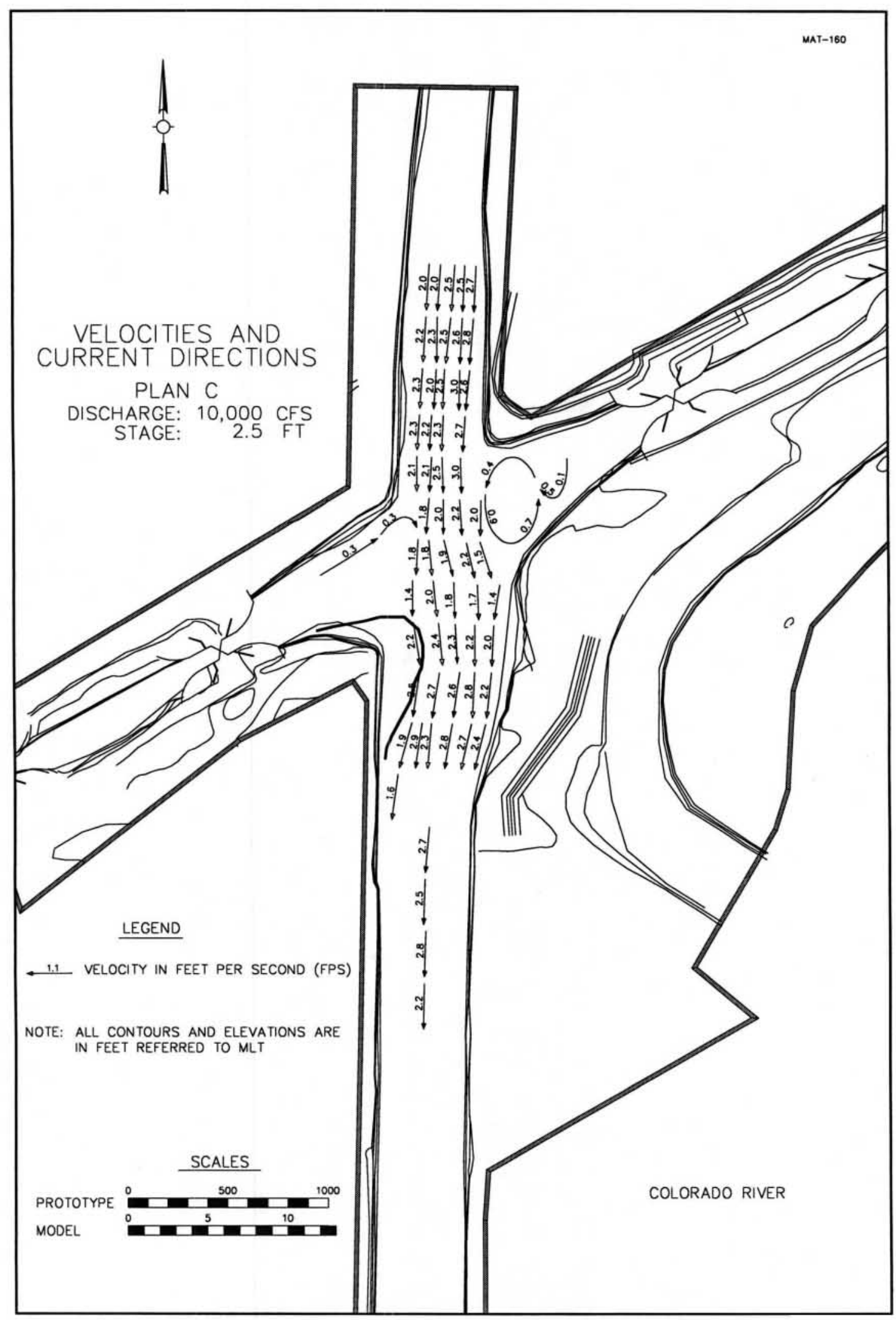

Plate 48 


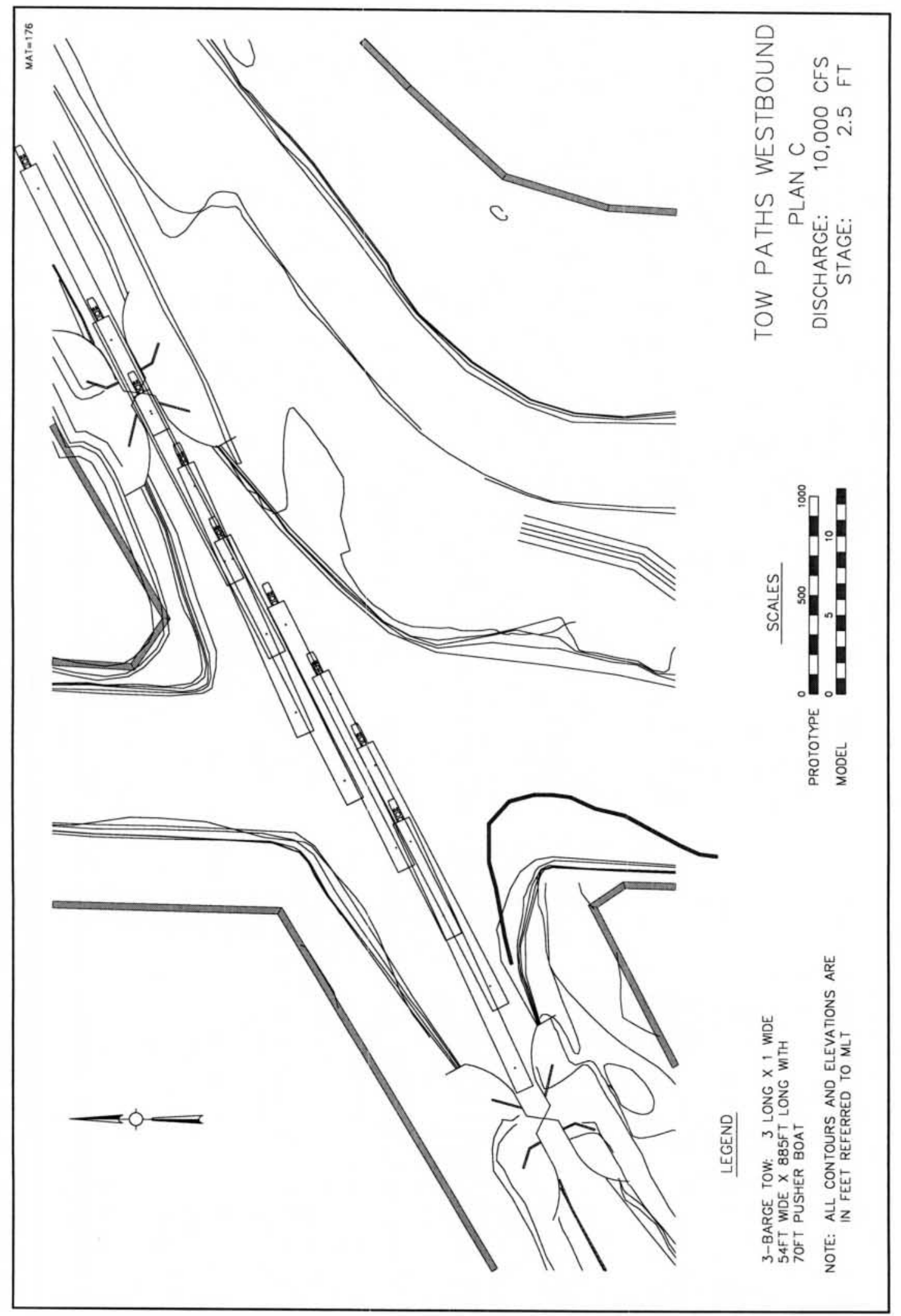

Plate 49 


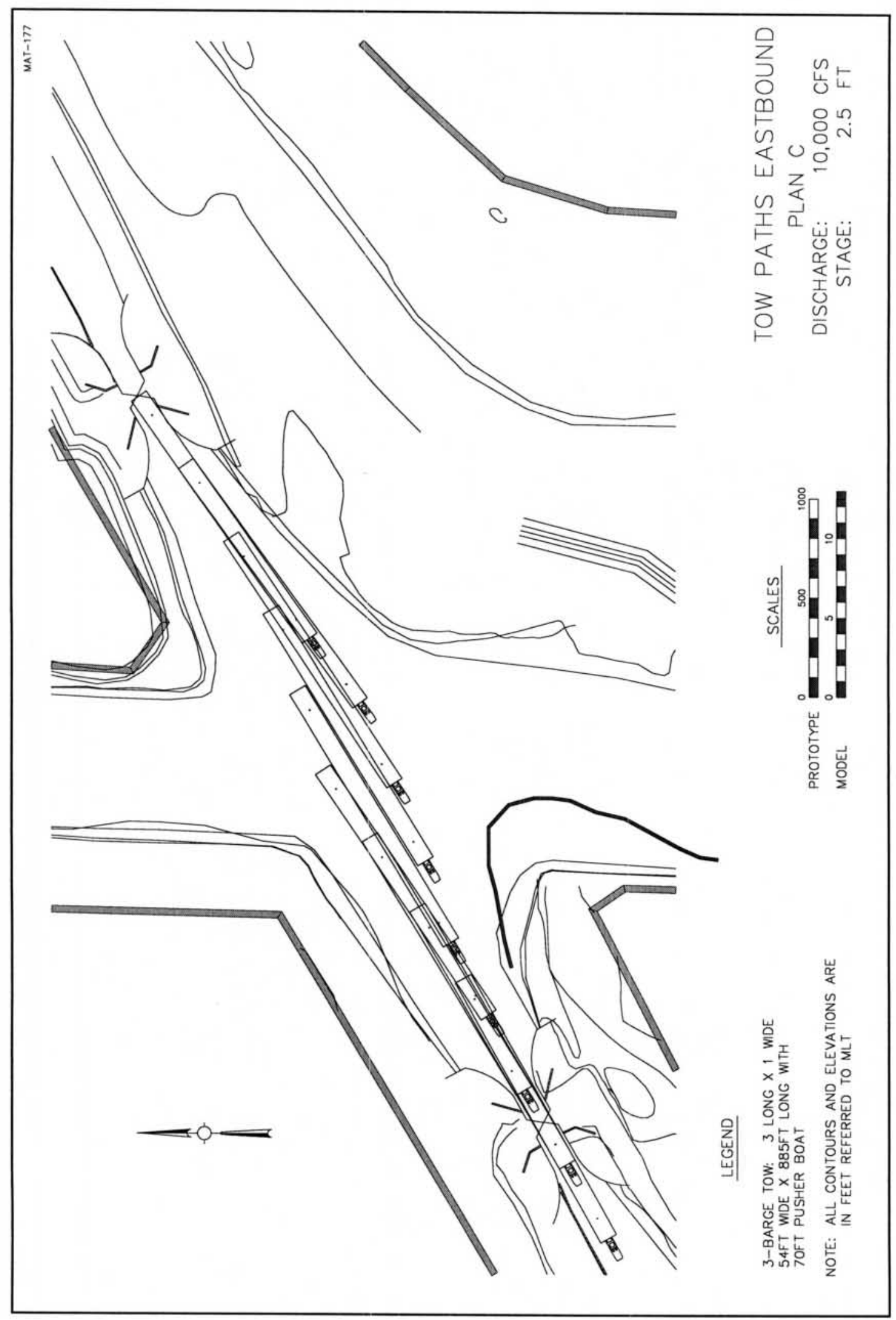

Plate 50 


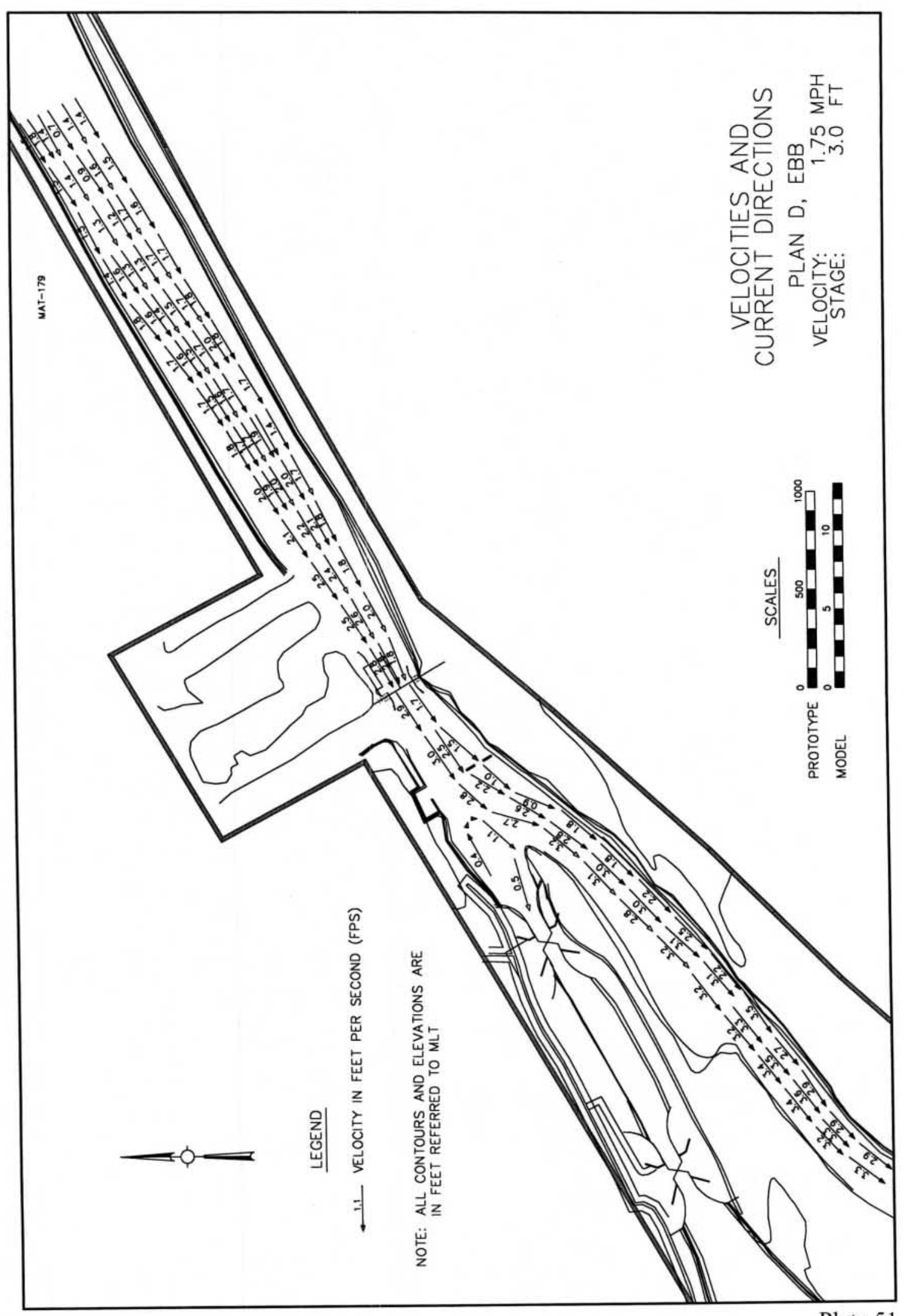

Plate 51 


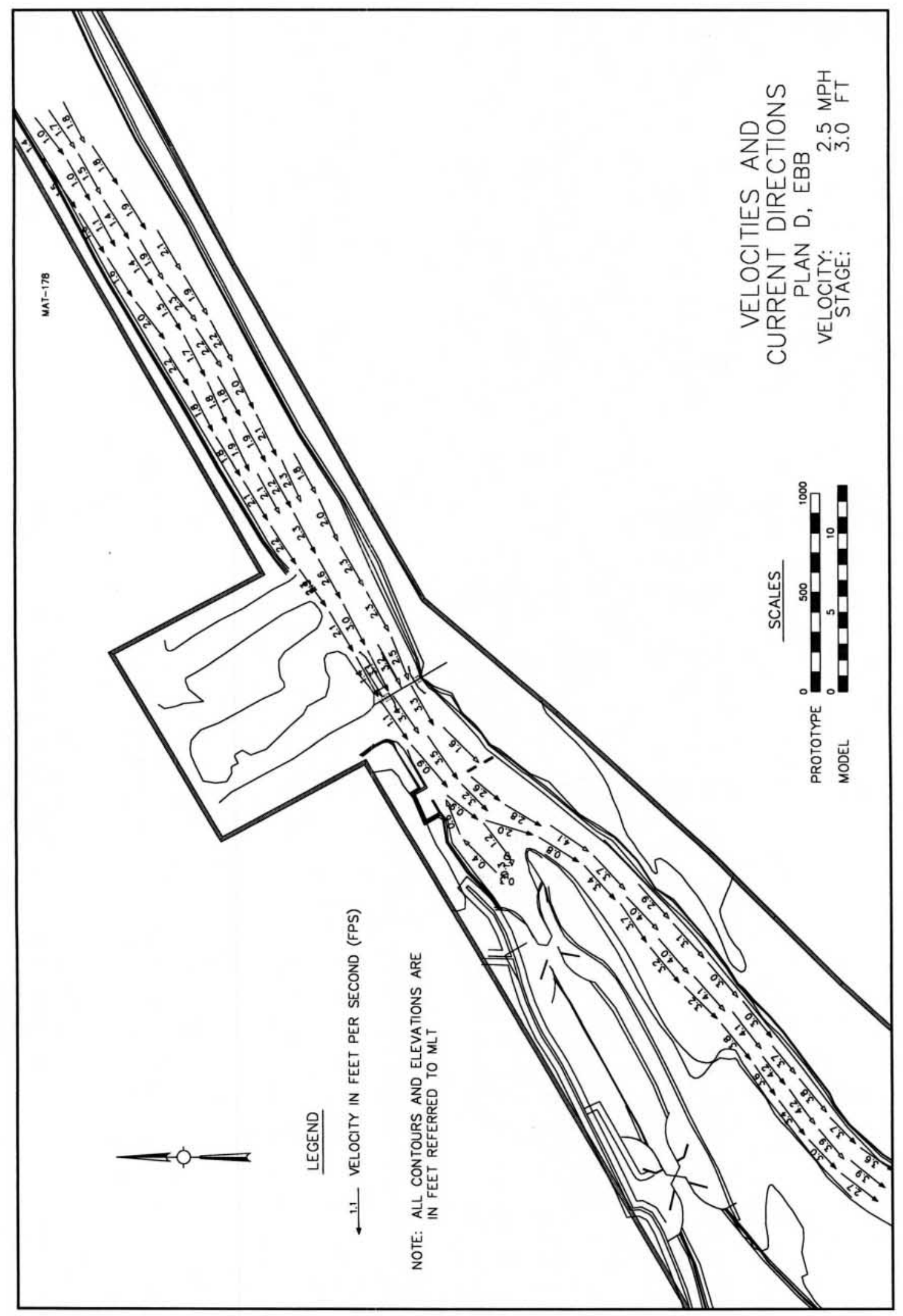

Plate 52 


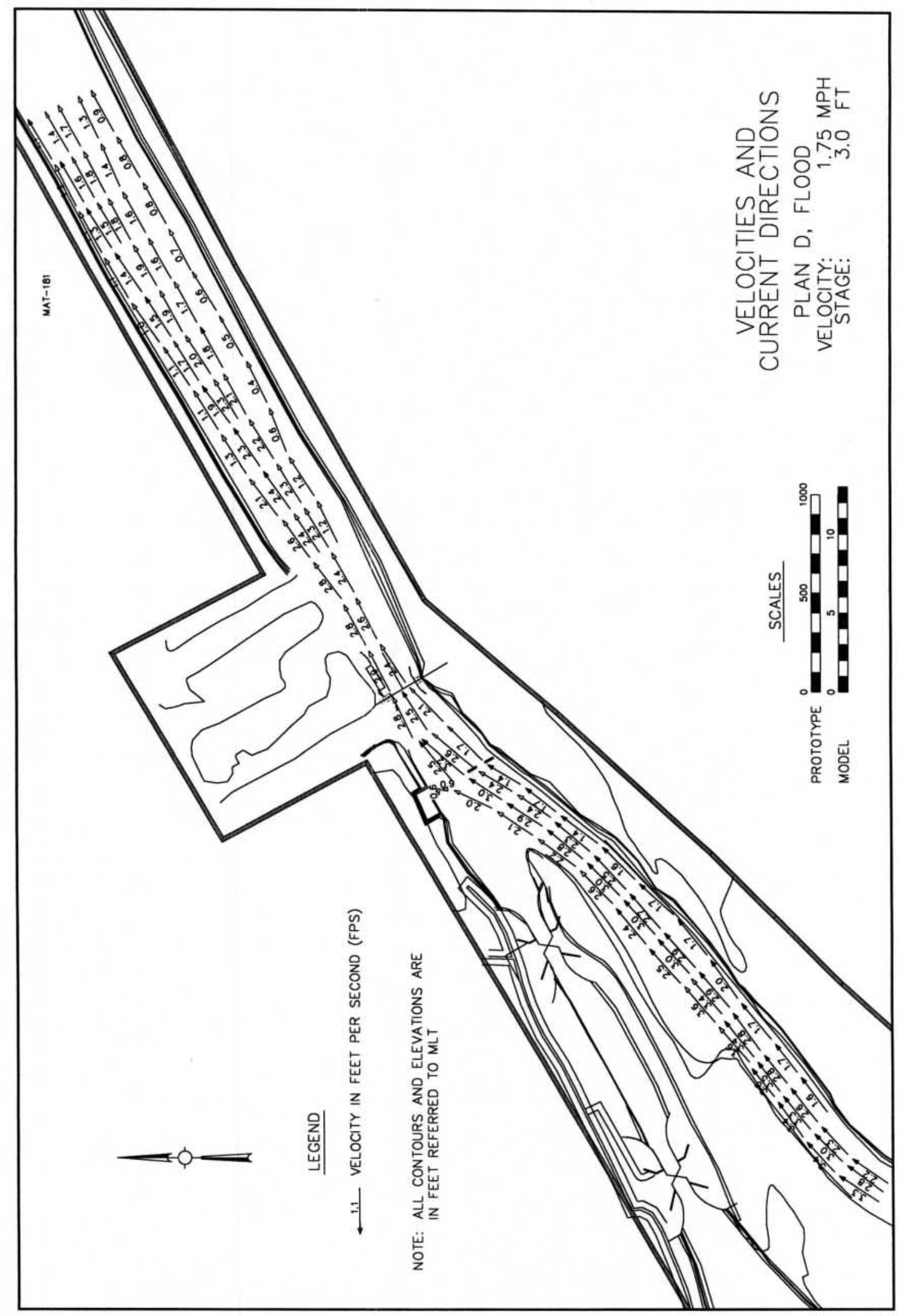

Plate 53 


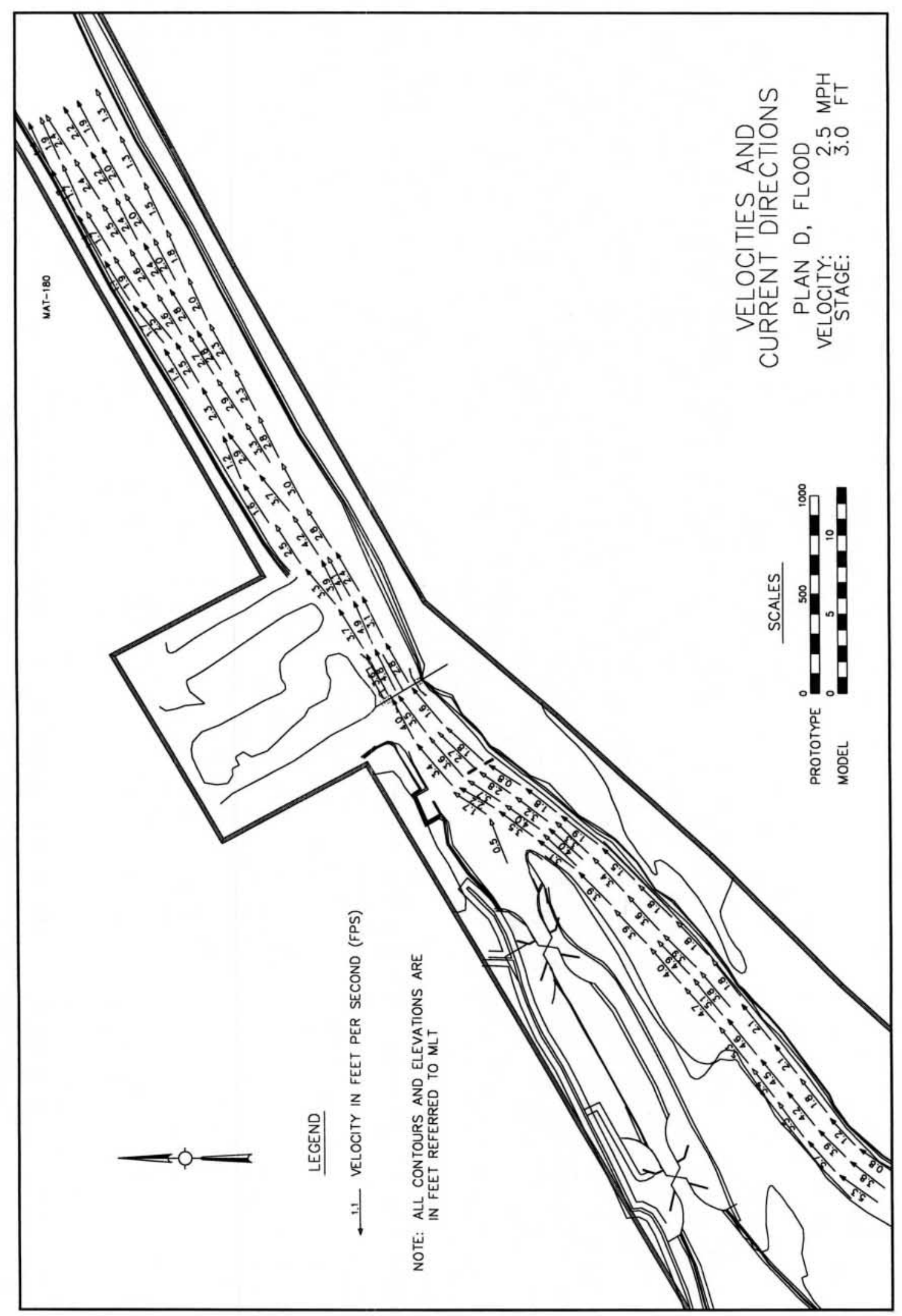

Plate 54 


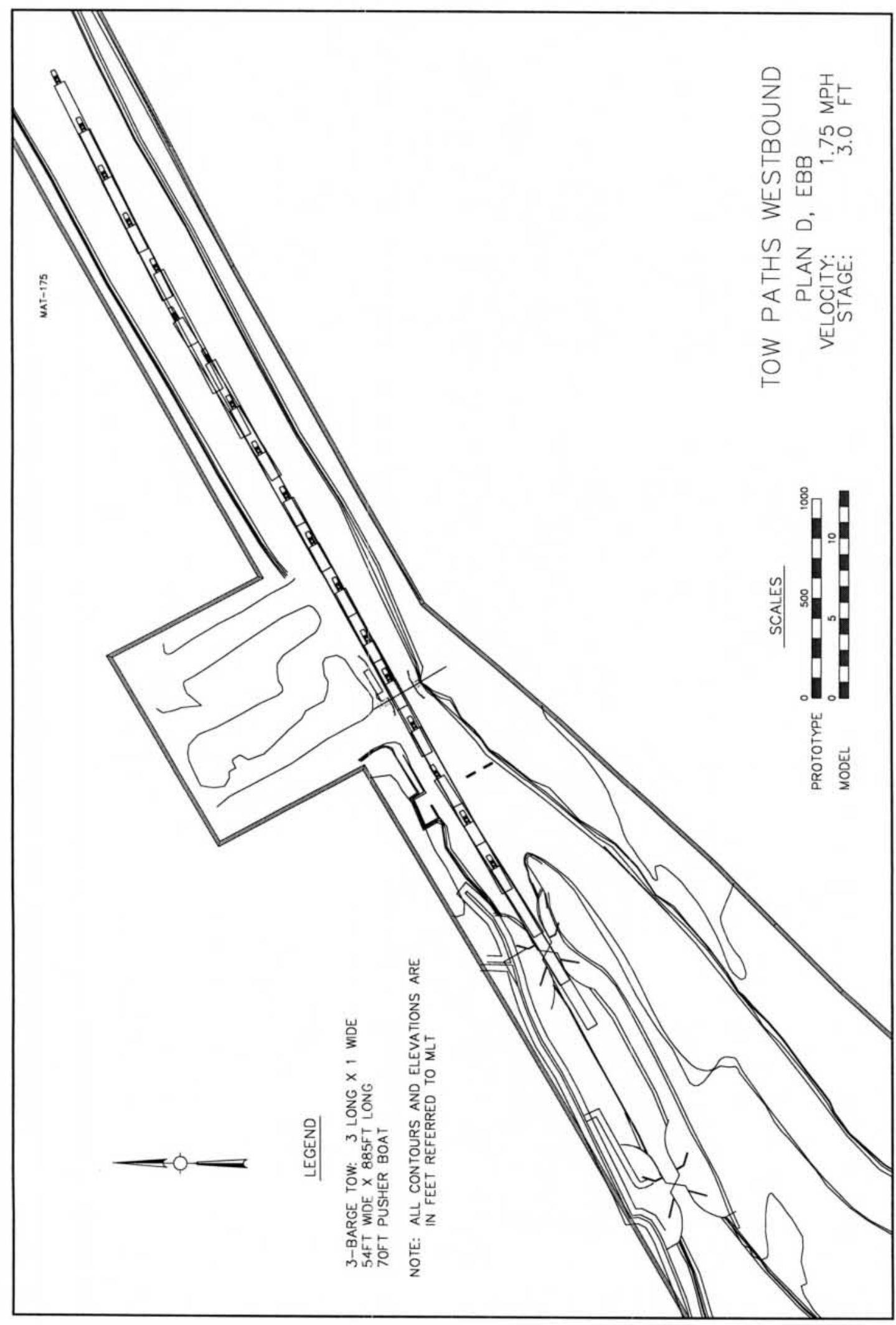

Plate 55 


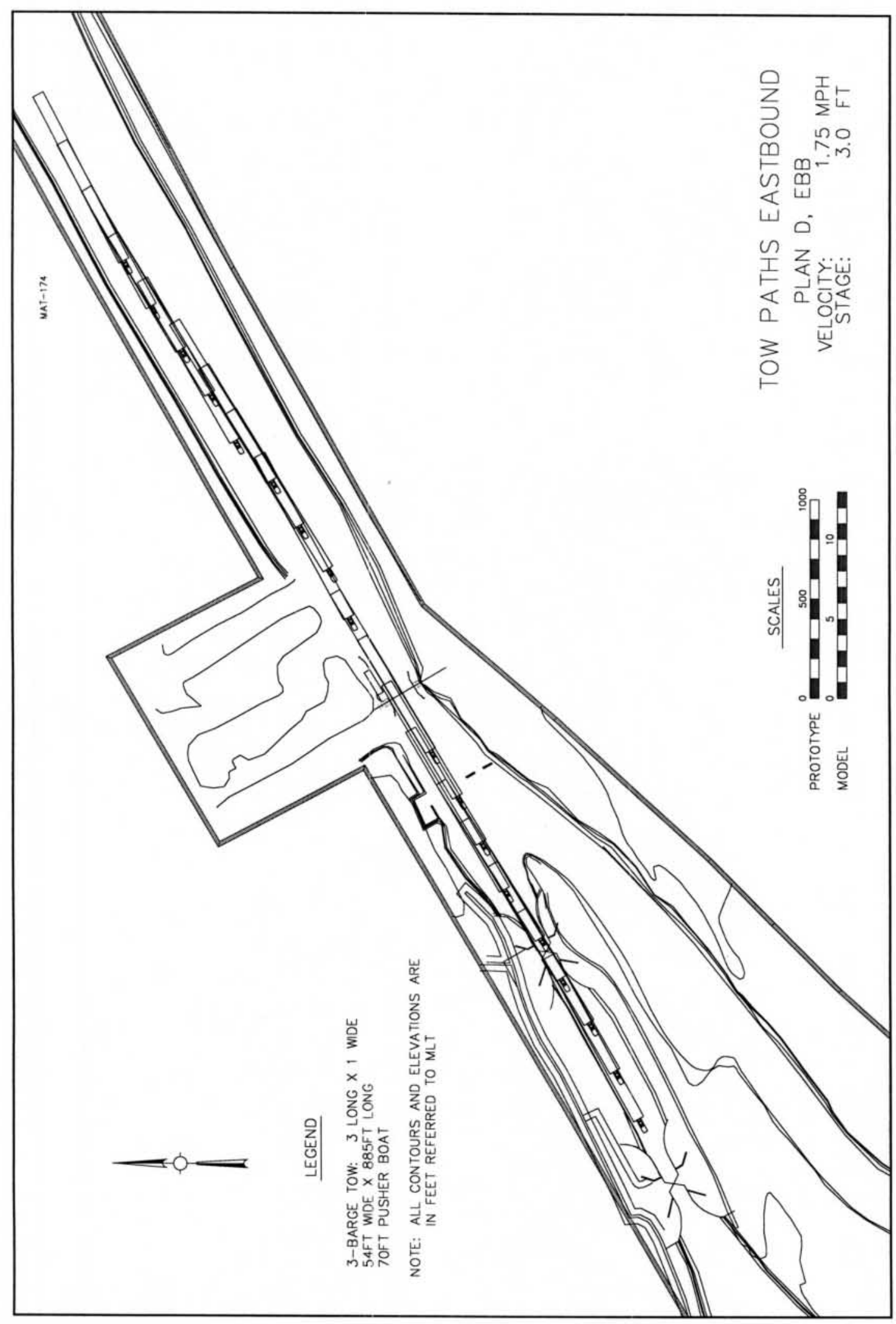

Plate 56 


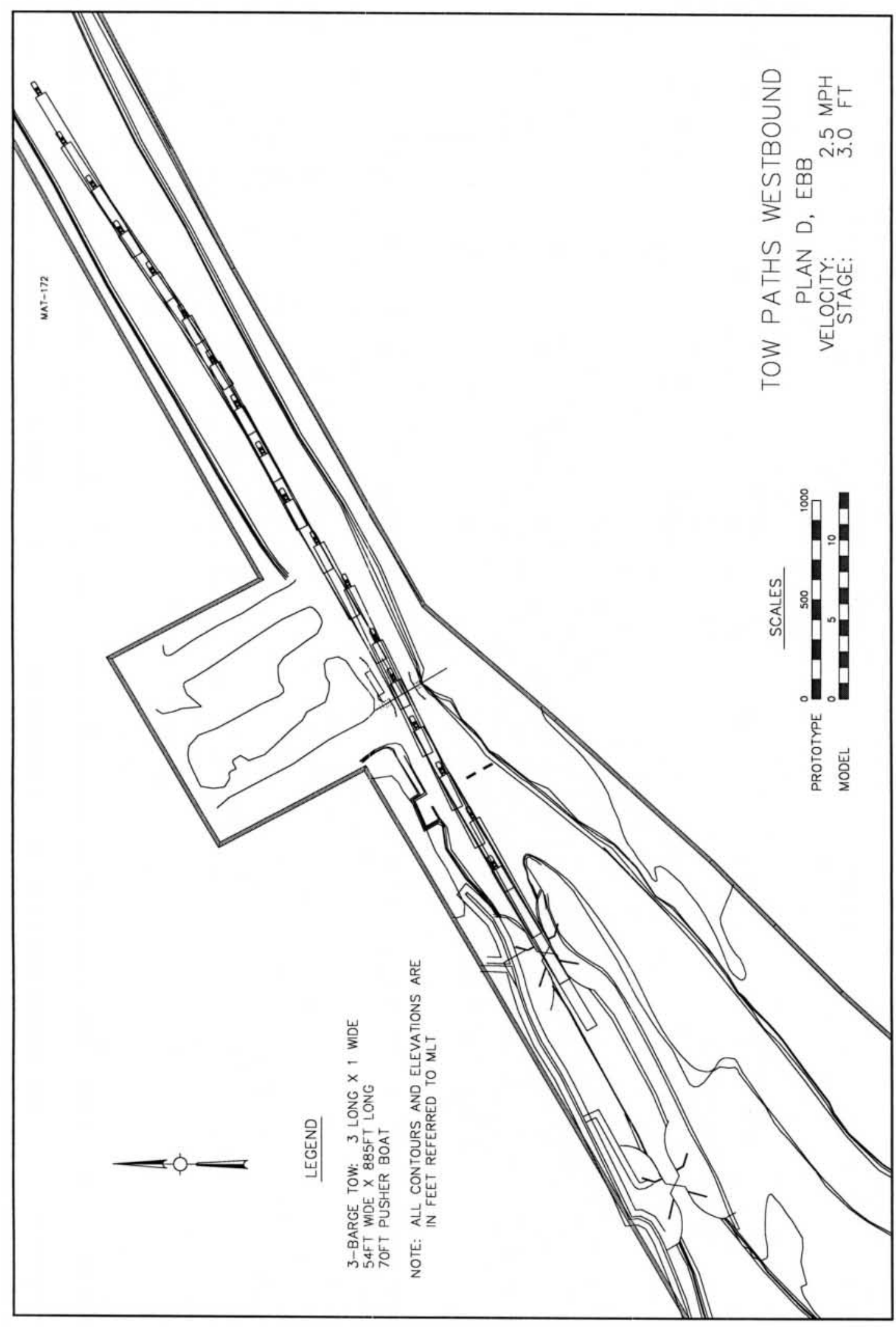

Plate 57 


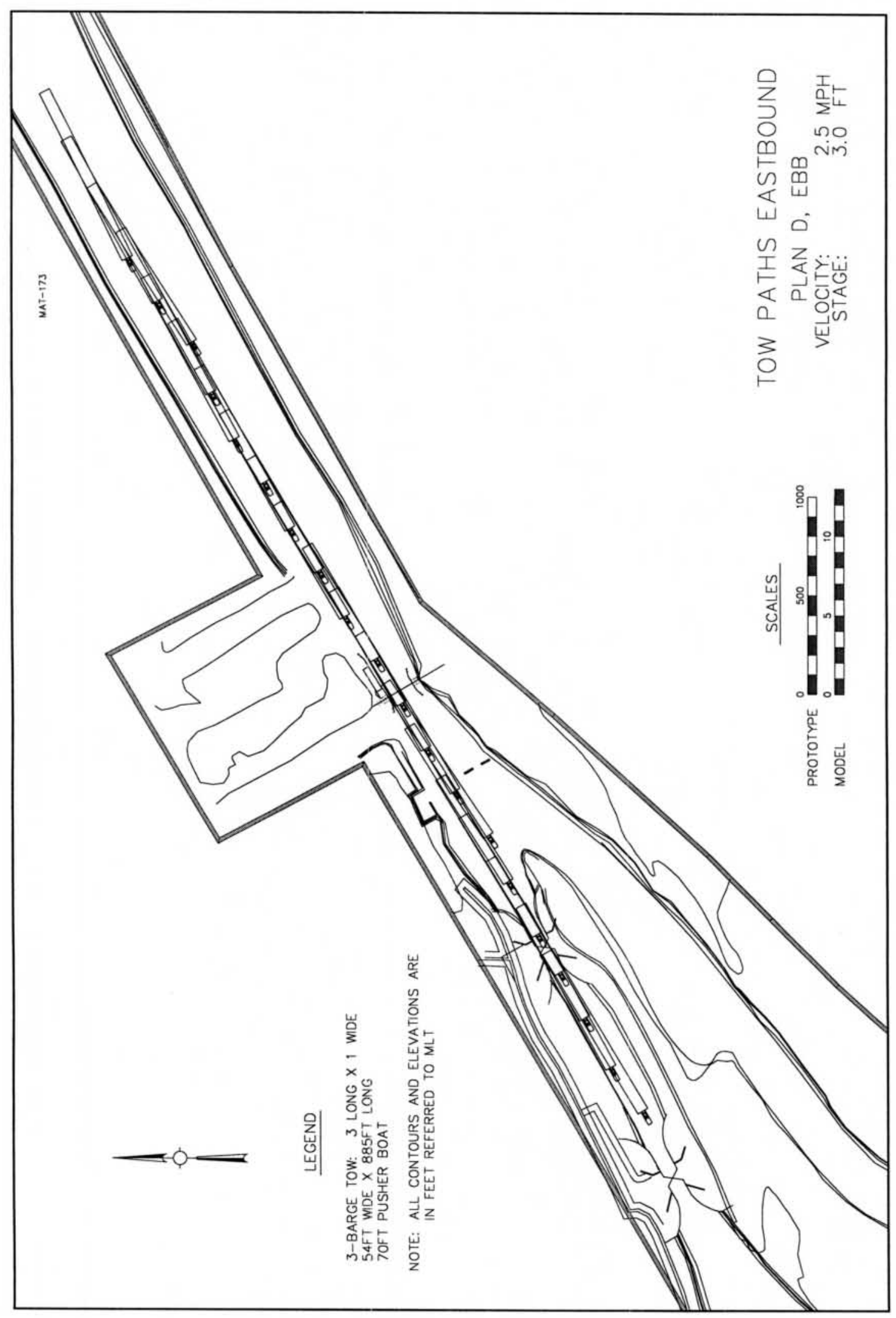

Plate 58 


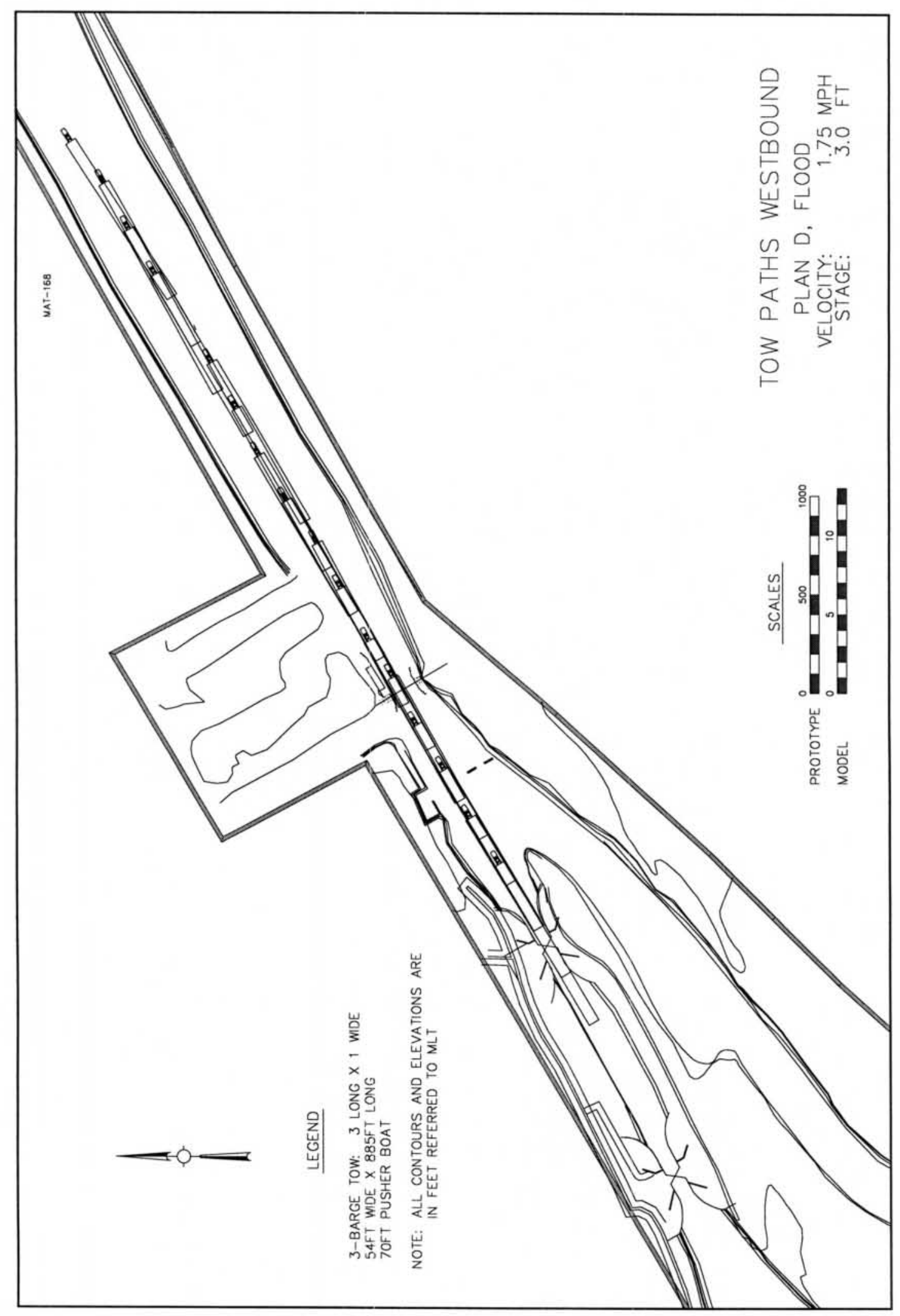

Plate 59 


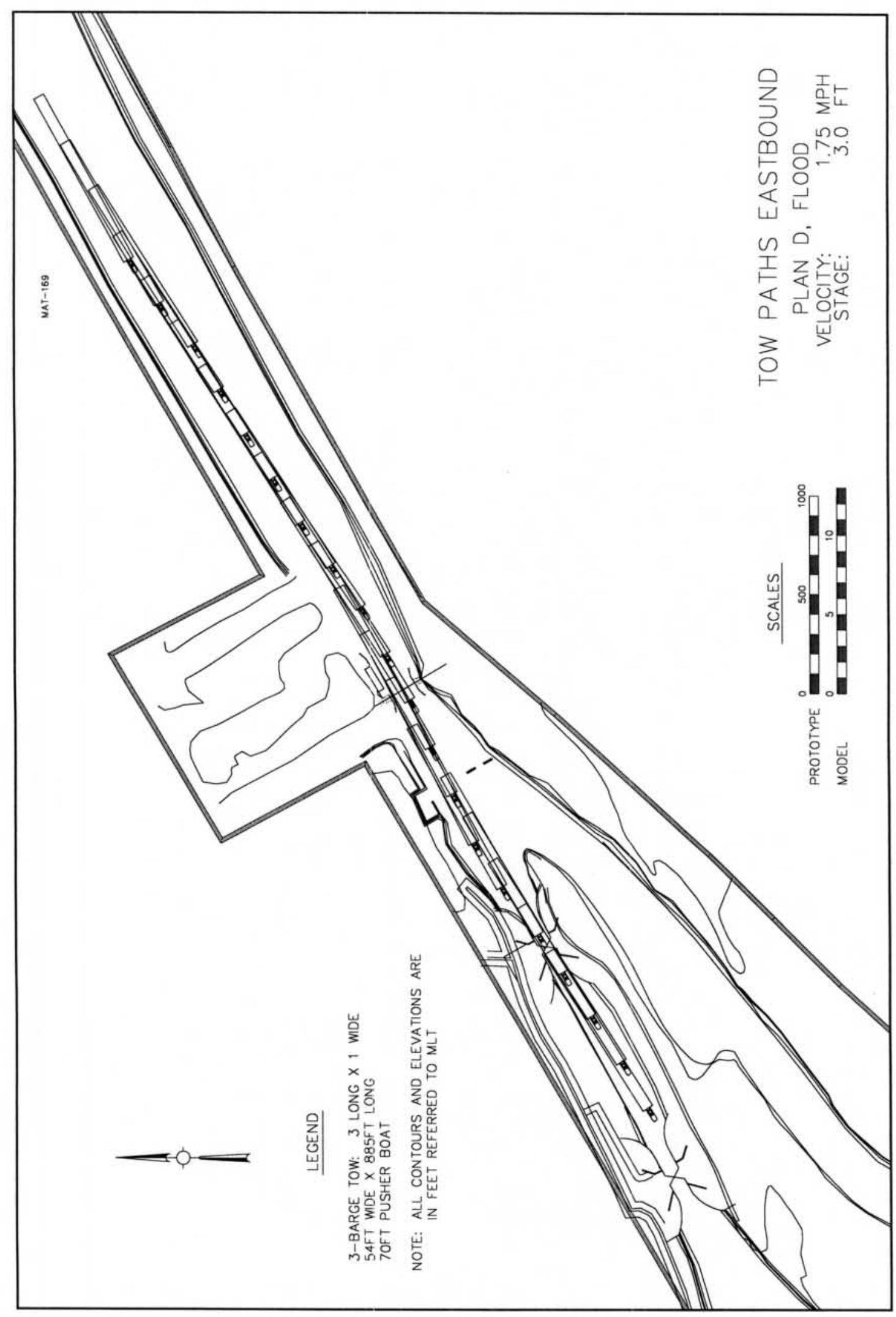

Plate 60 


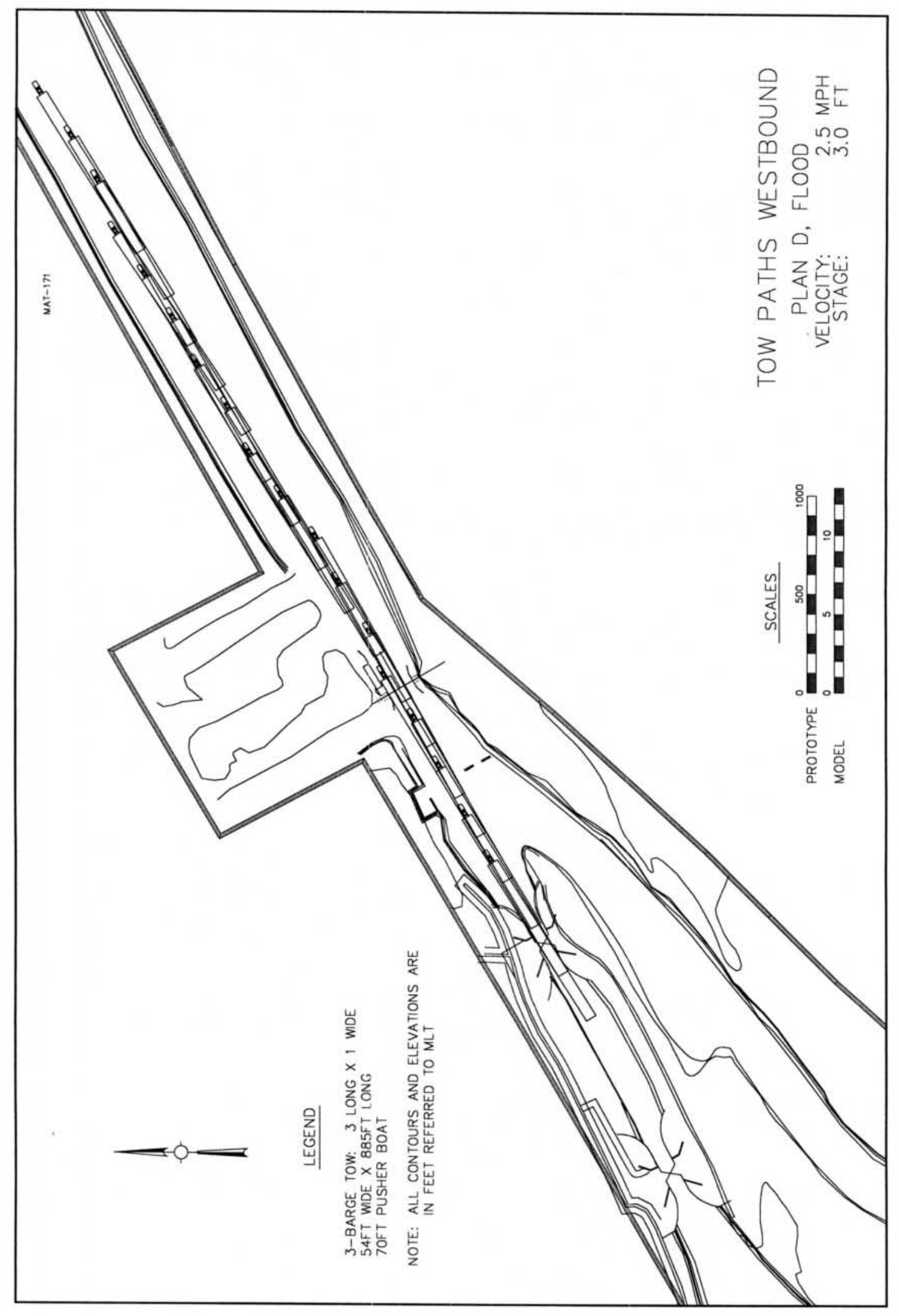

Plate 61 


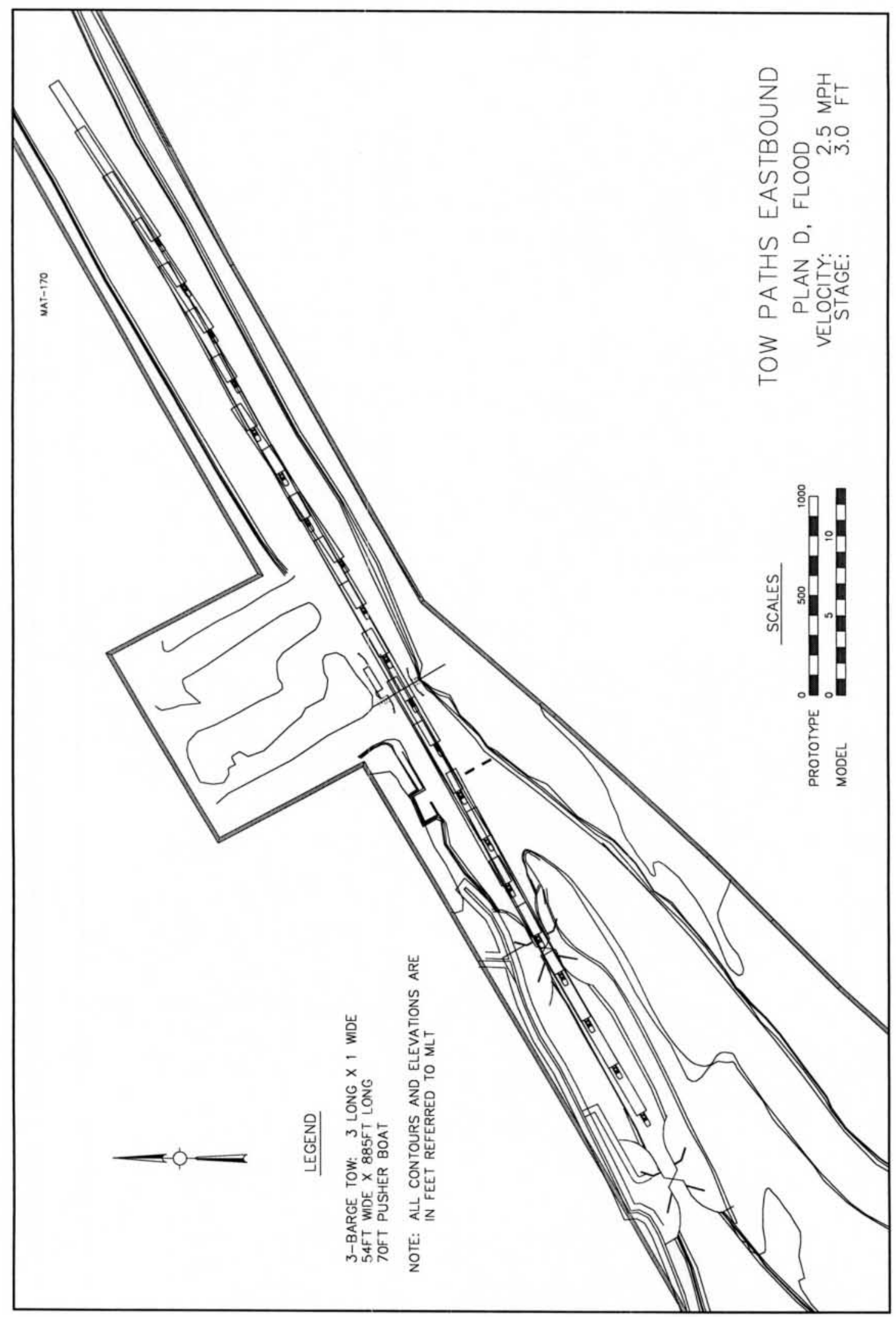

Plate 62 


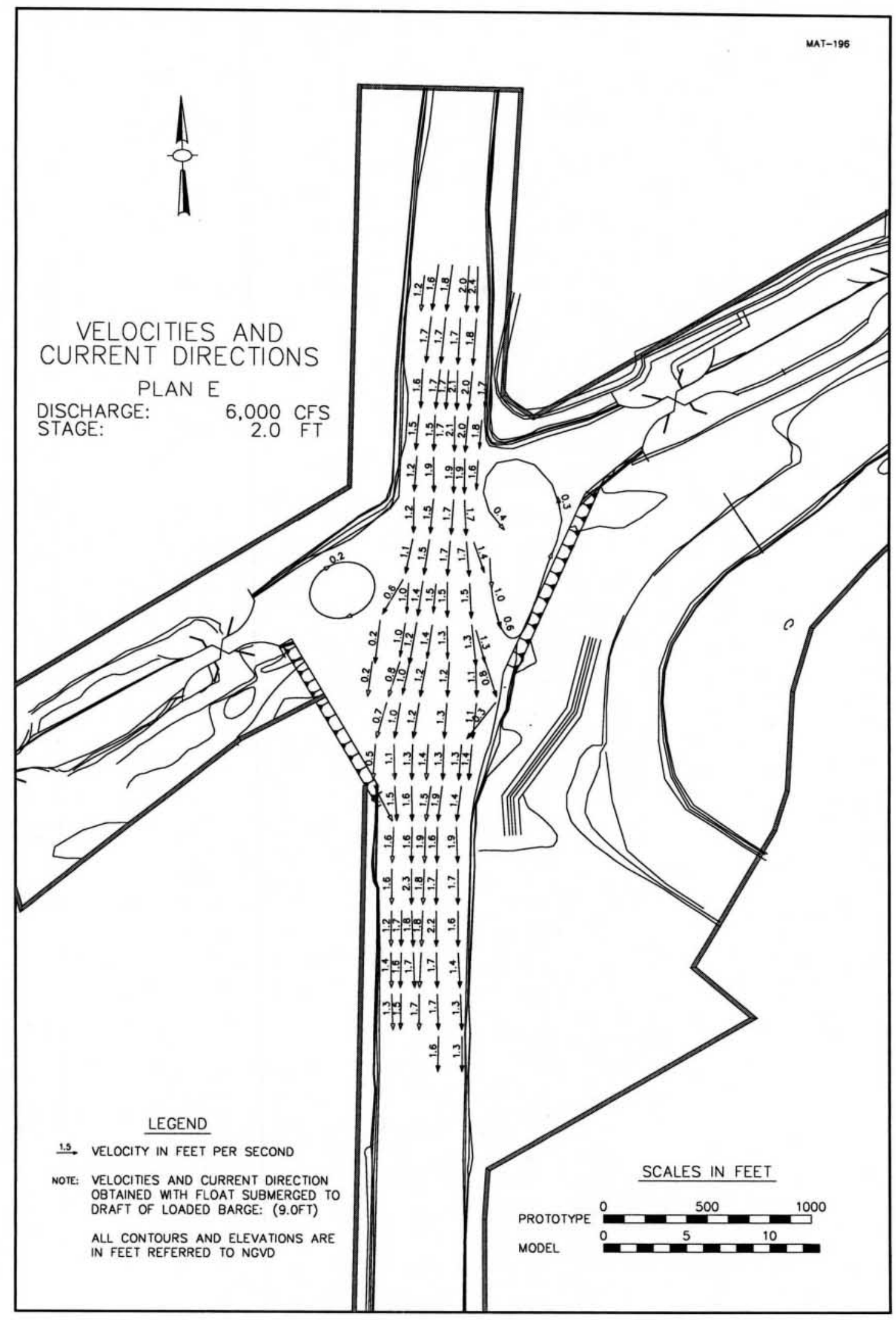

Plate 63 


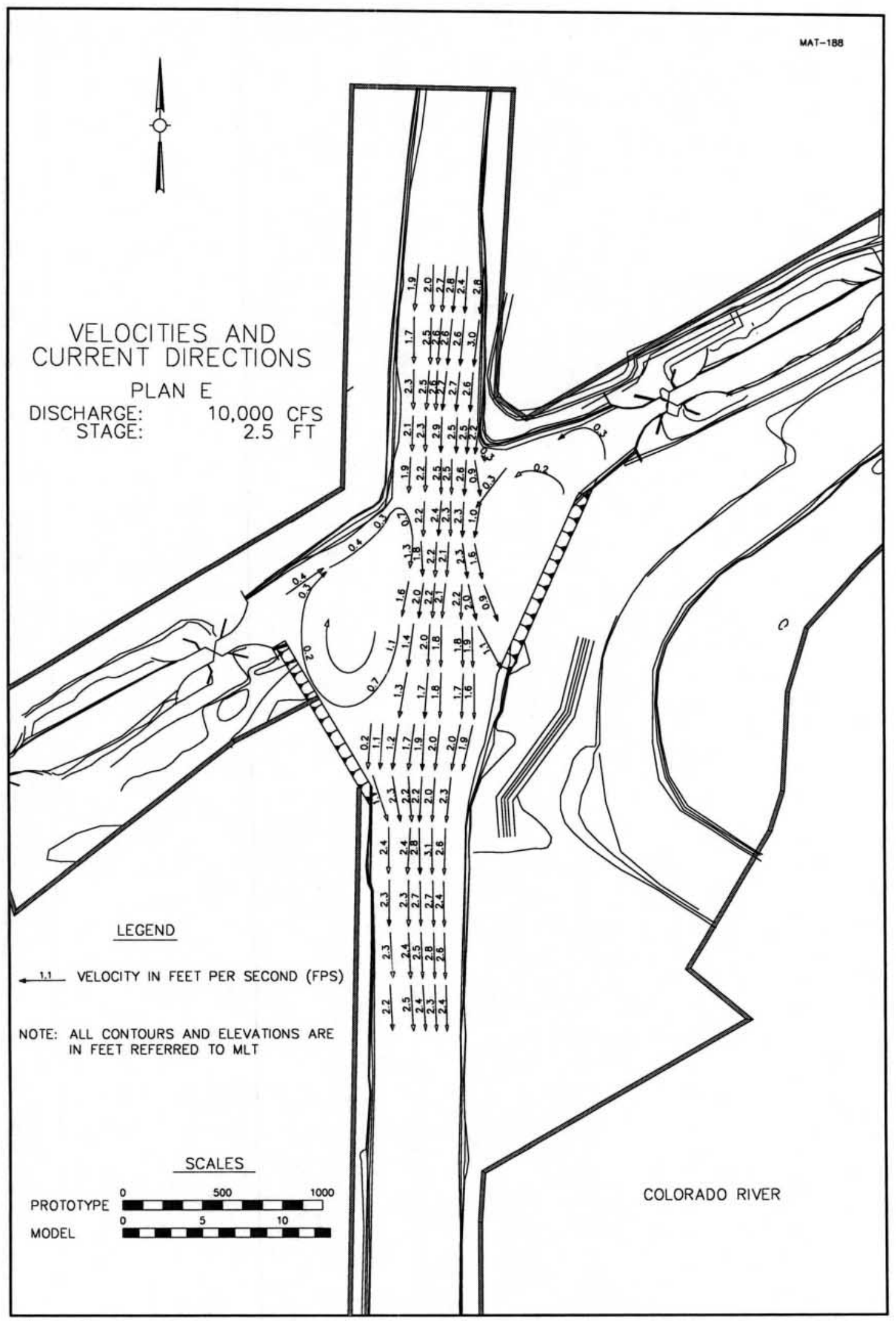

Plate 64 


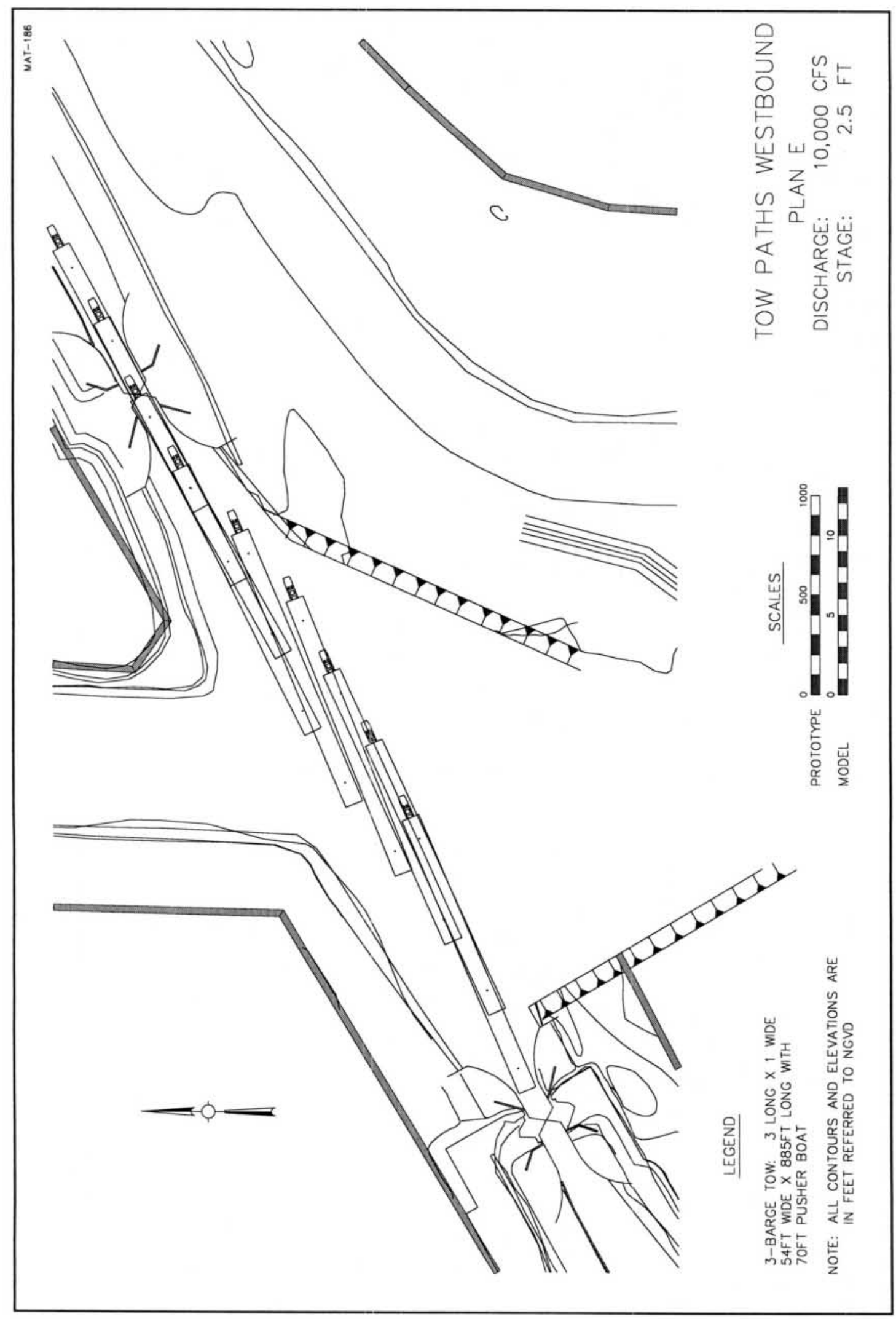

Plate 65 


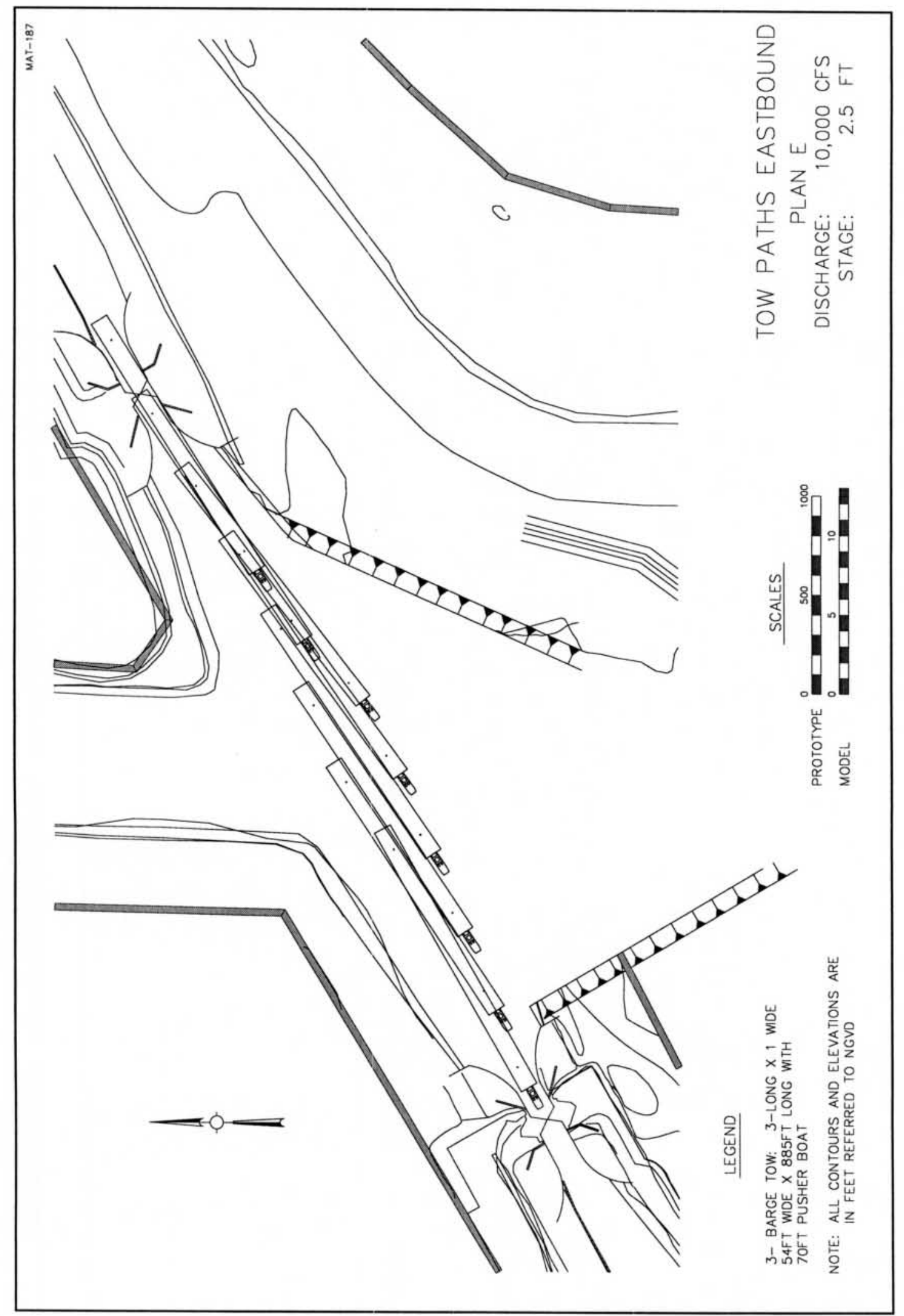

Plate 66 


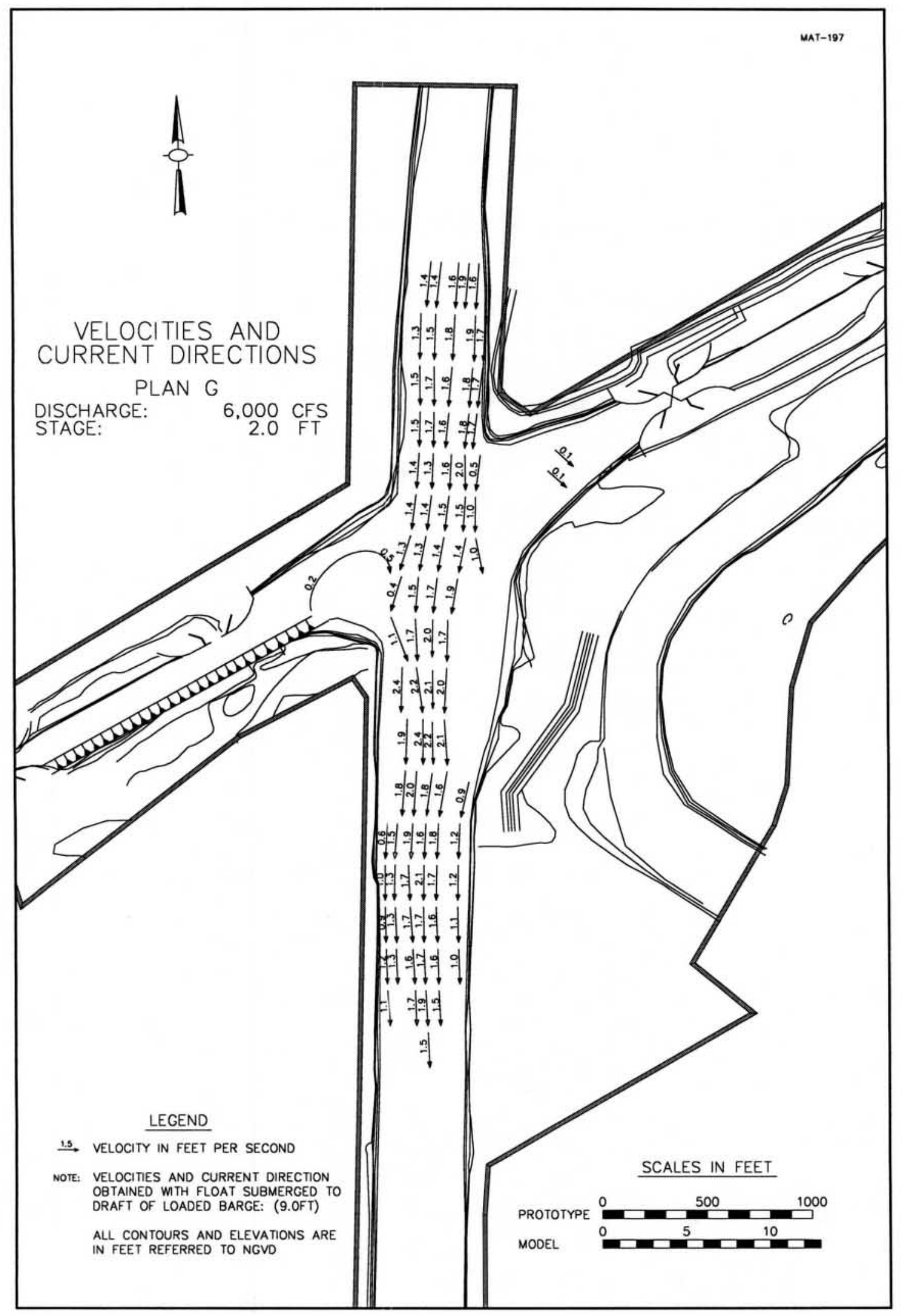

Plate 67 


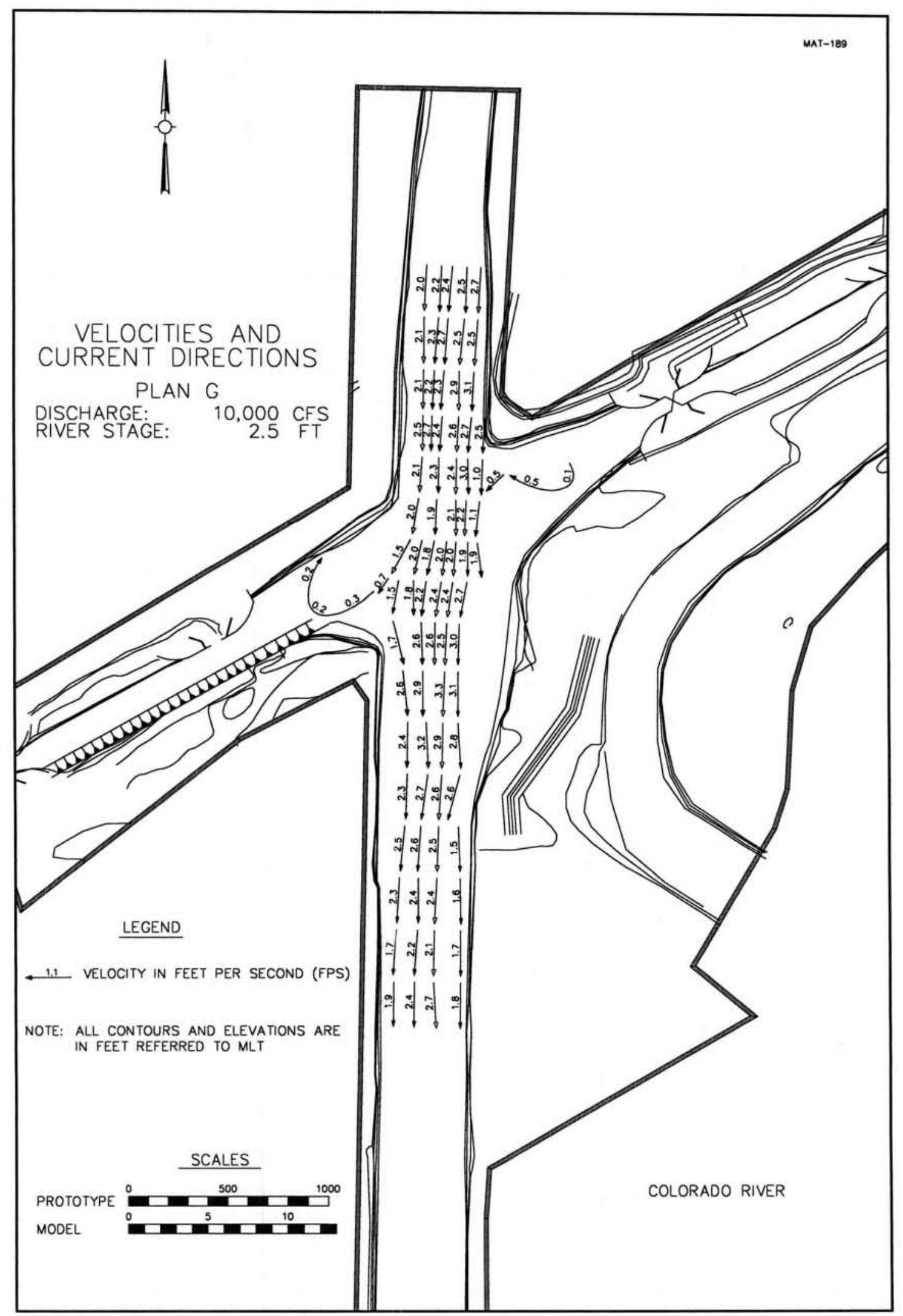

Plate 68 


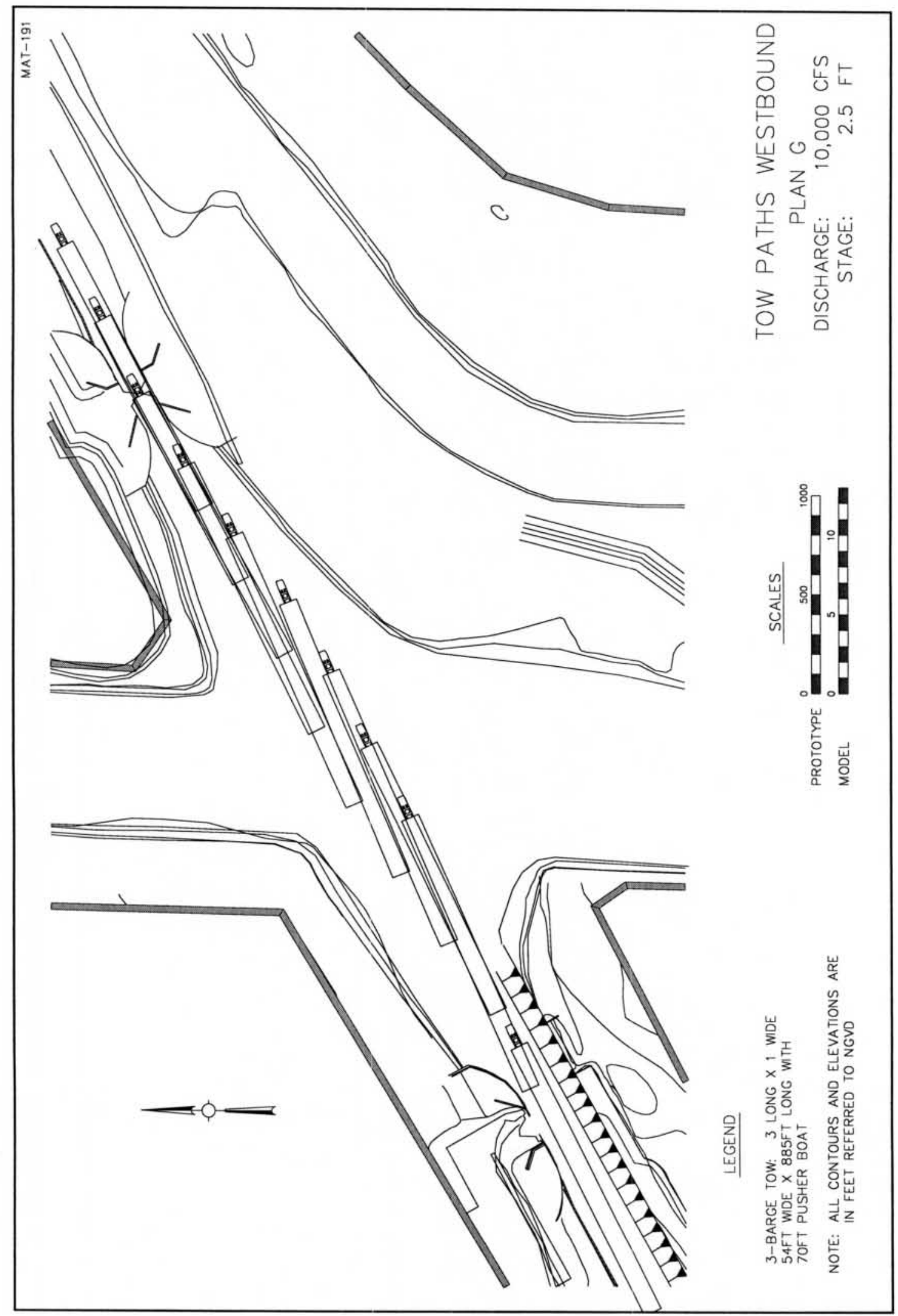

Plate 69 


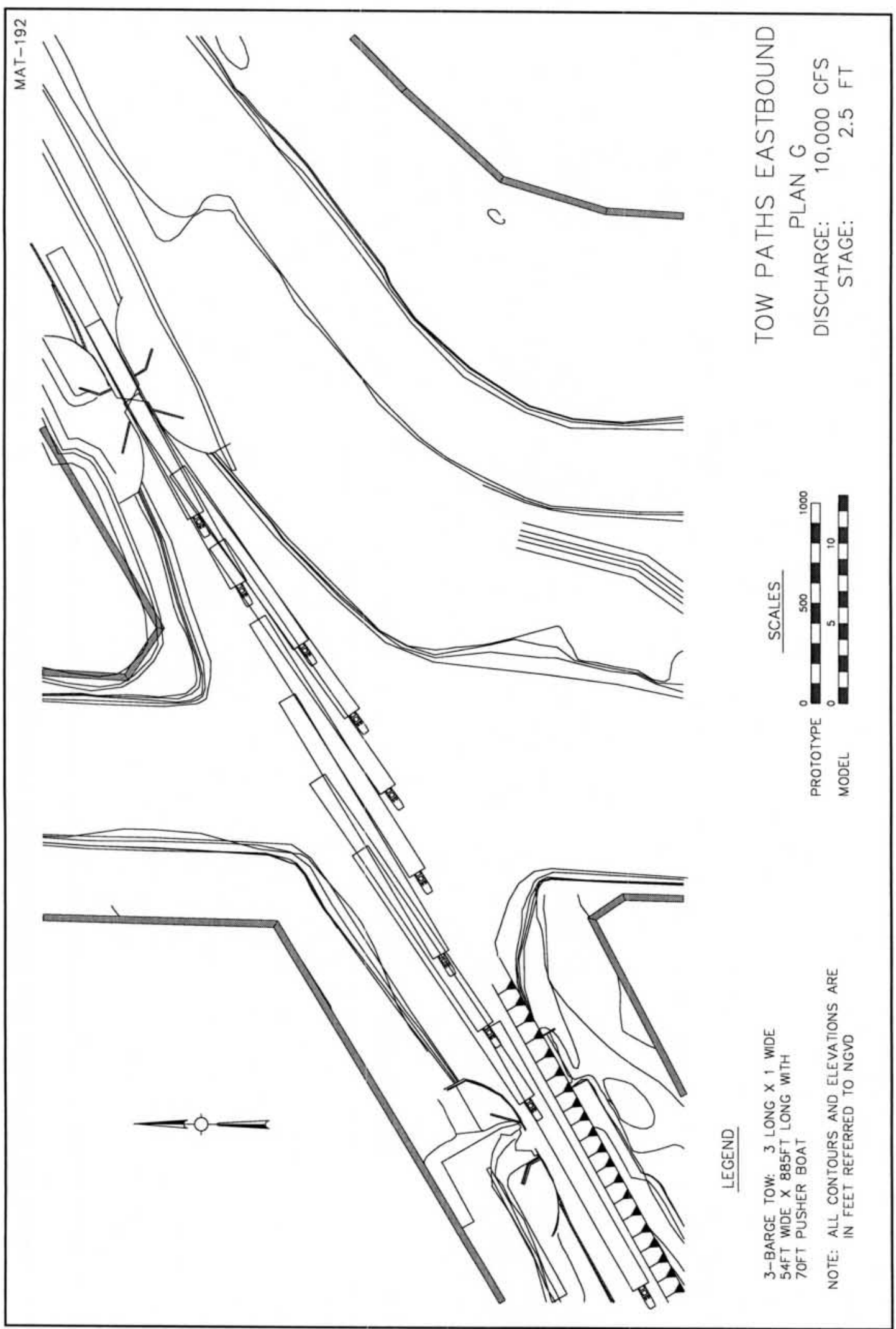

Plate 70 


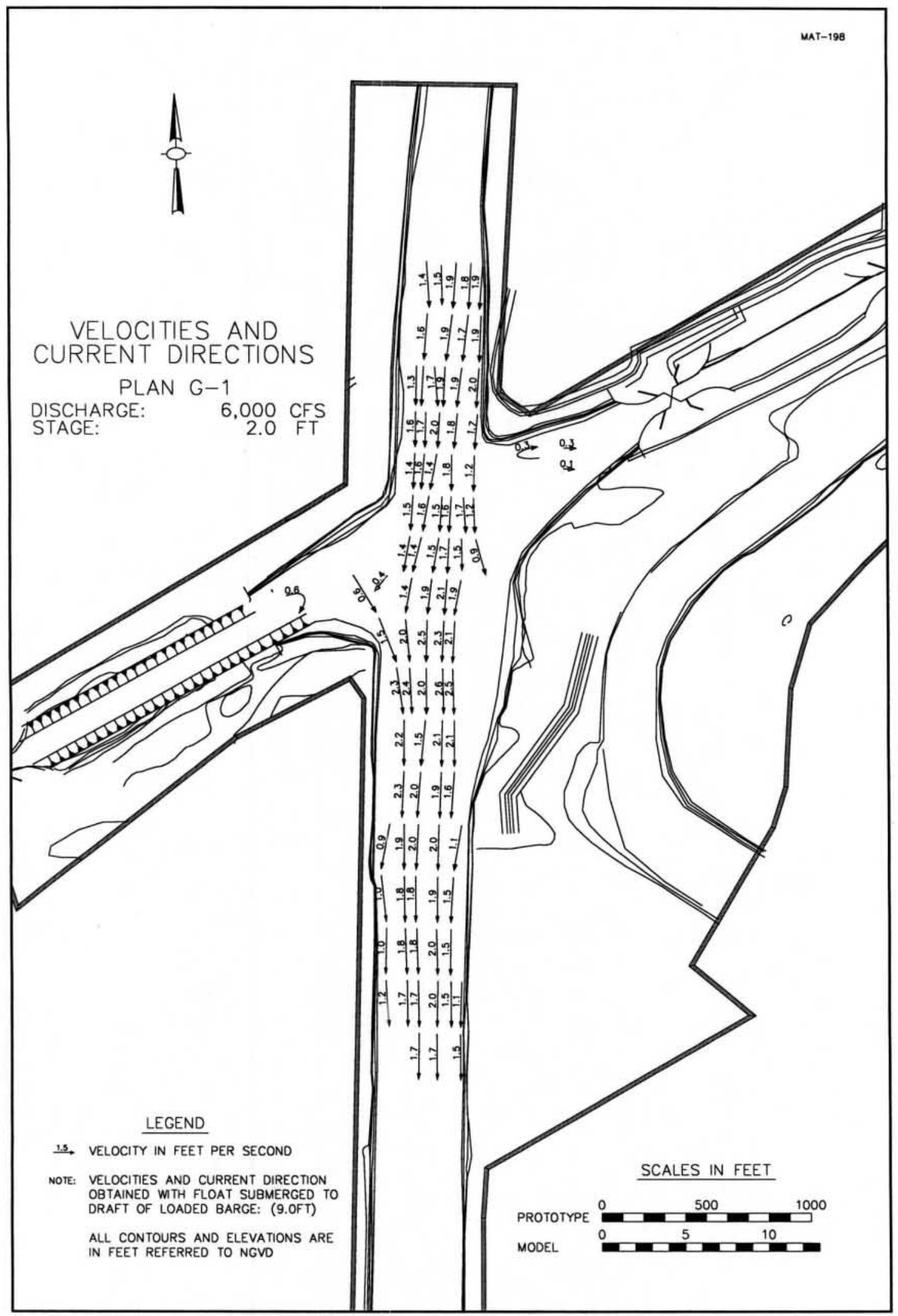

Plate 71 


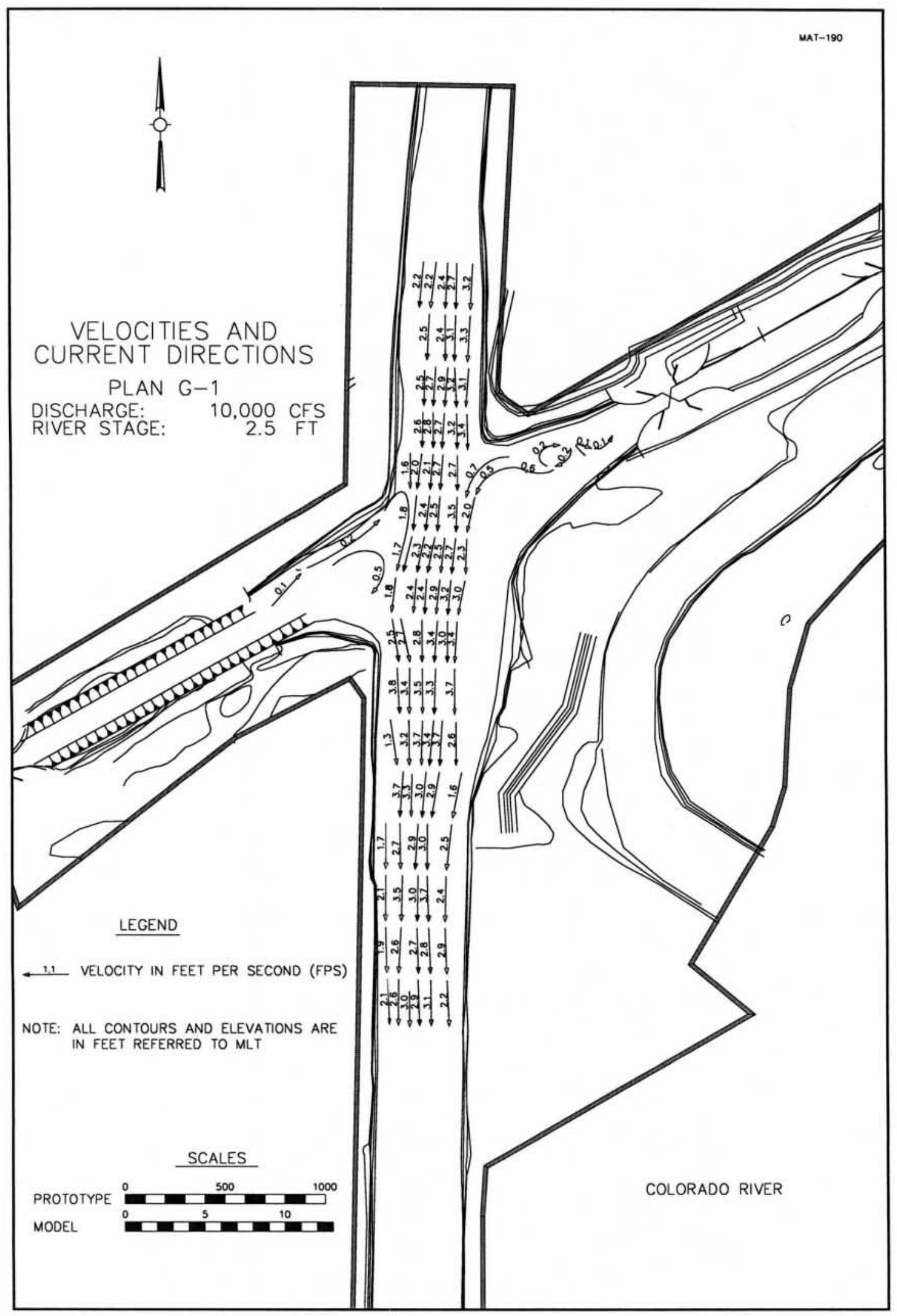

Plate 72 


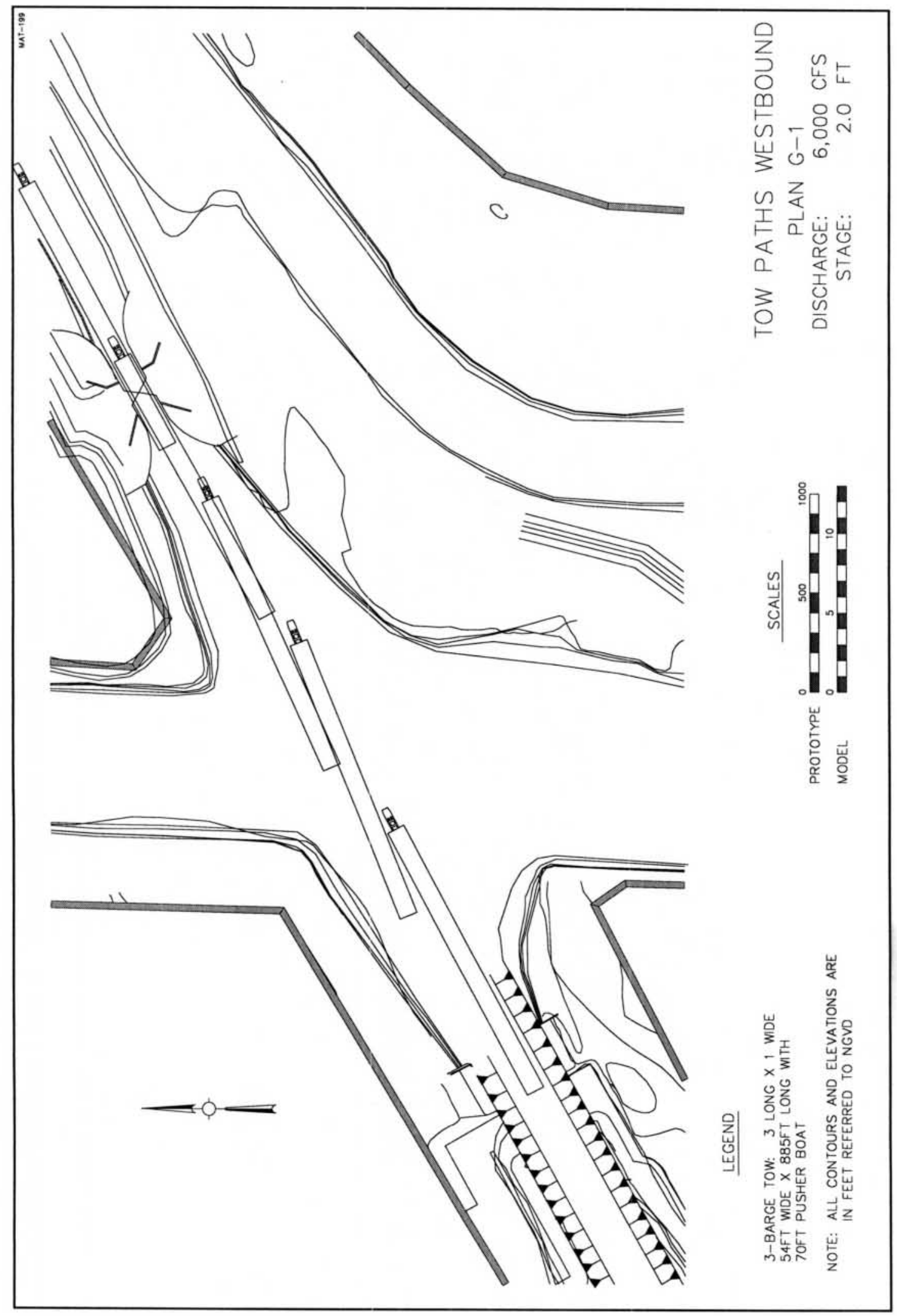

Plate 73 


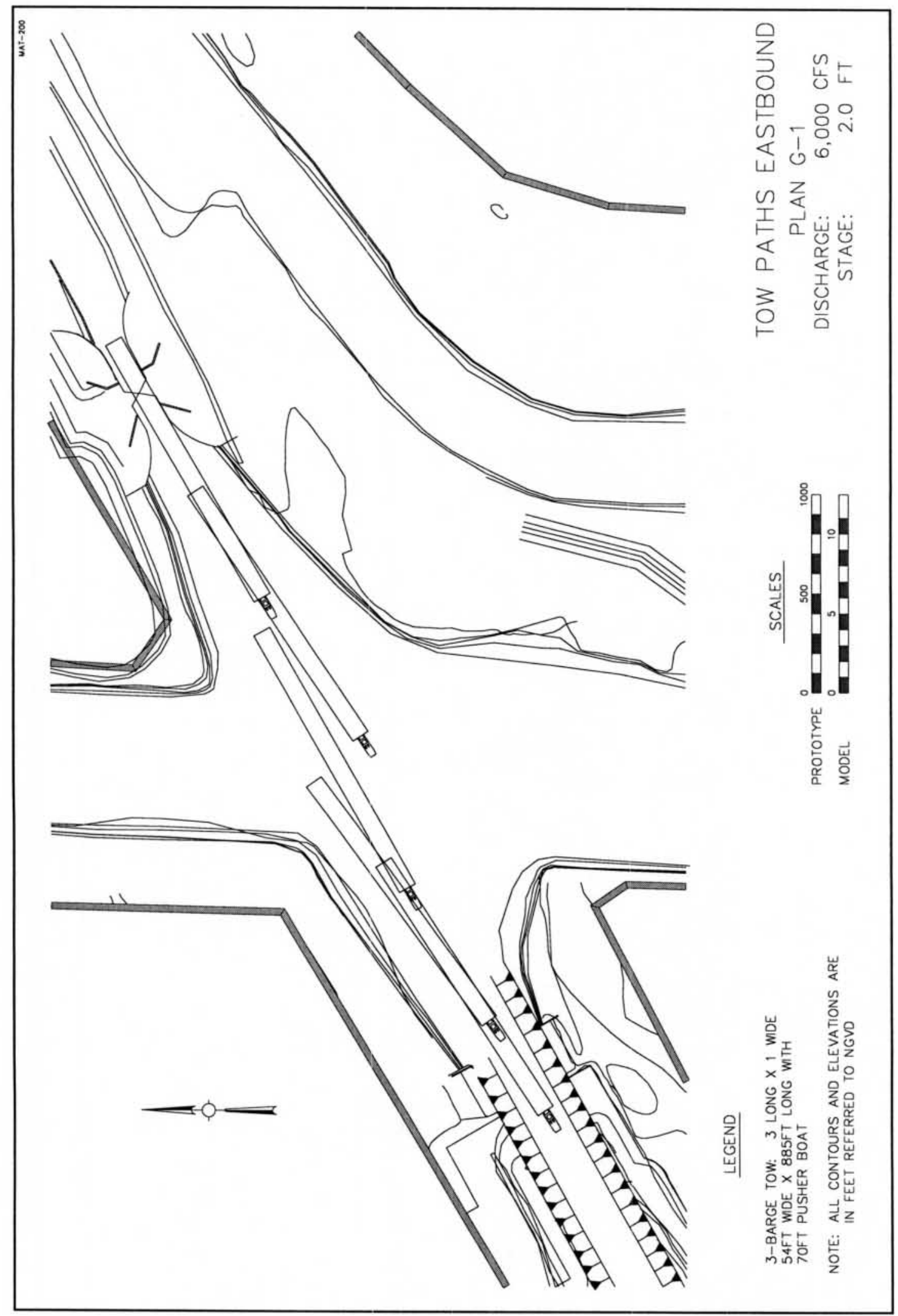

Plate 74 


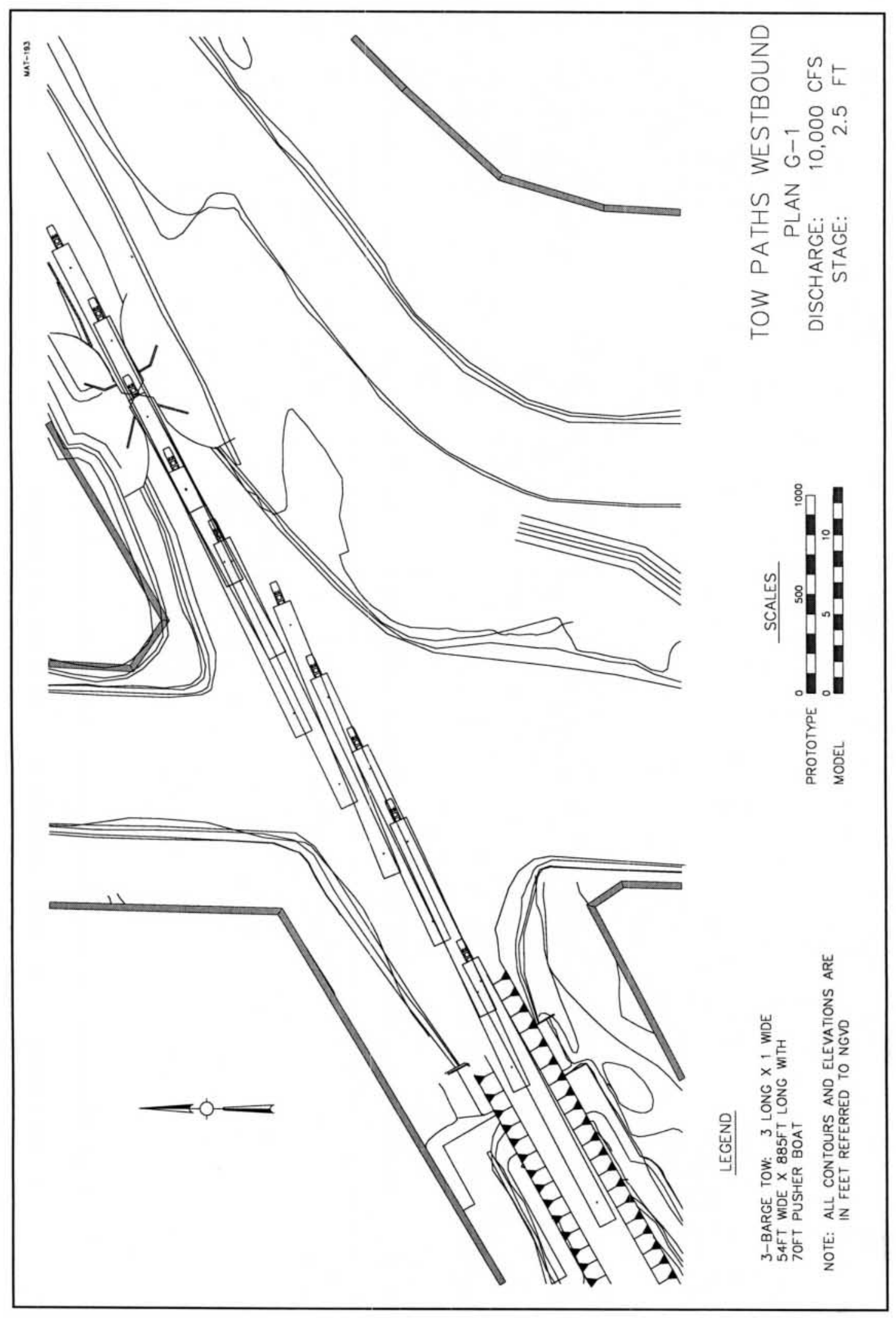

Plate 75 


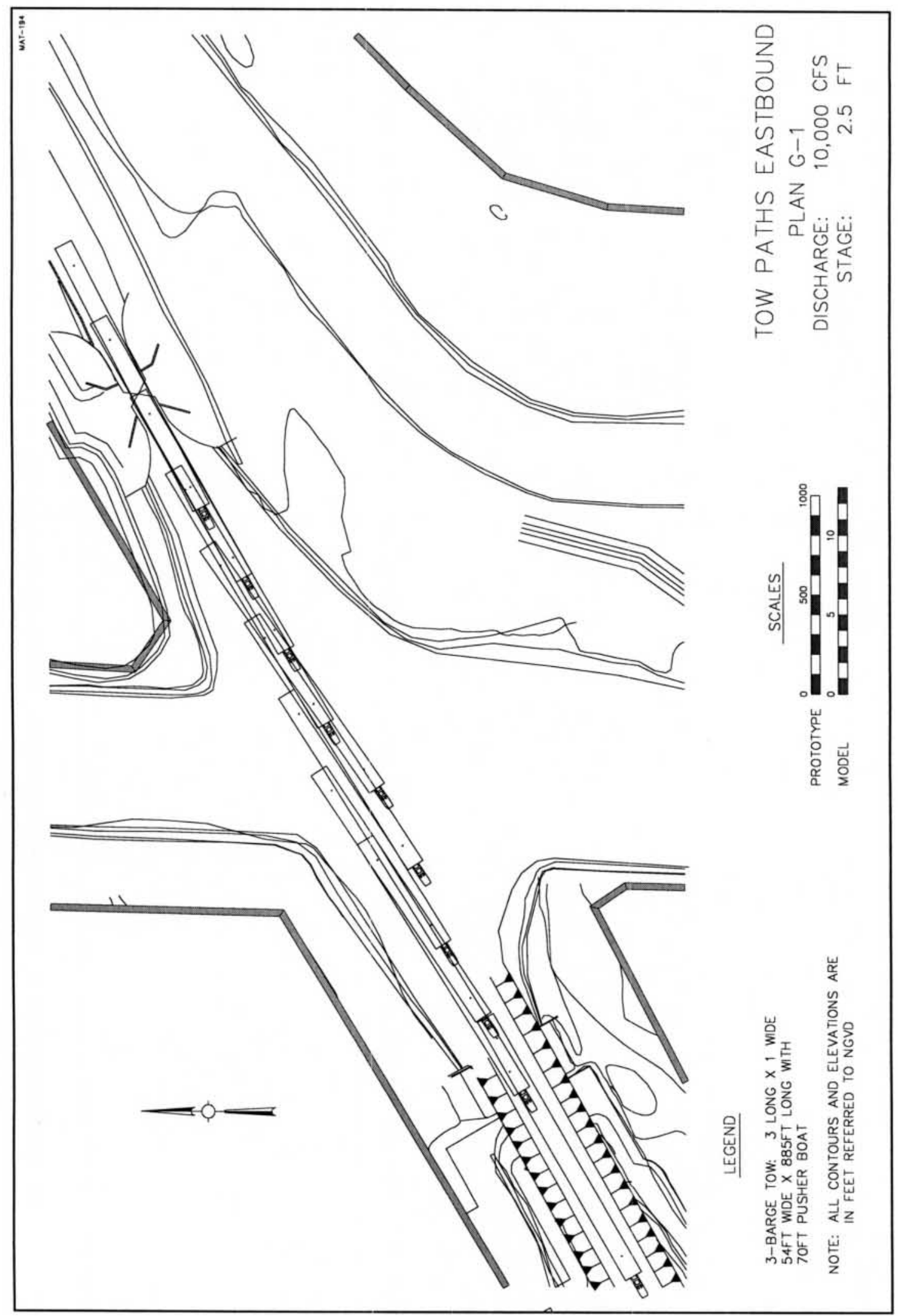

Plate 76 


\section{Appendix A Colorado River Southwest Corner Stabilization}

\section{Objective}

The objective of this study is to develop alternatives to prevent erosion of the Southwest (SW) corner of the intersection of the Gulf Intracoastal Waterway (GIWW) and the Colorado River (CR). The protection alternatives must also be suitable for westbound tows to land against if they are unable to cross the CR. This study is not intended to solve the navigation problem which was addressed in McCollum (in preparation) but does present one possible solution.

\section{Background}

The GIWW/CR intersection is shown in Figure A1. Prior to 1990, the CR flowed in the river channel east of the present dredged channel. In 1990, a diversion channel to Matagorda Bay was dredged and a closure structure was placed across the old river channel. Since that time, some erosion of the SW corner has occurred during high flows. Based on observations by lock personnel, the erosion occurred not from downstream directed velocities but from velocities moving in an upstream direction that were part of an eddy that extended about $60 \mathrm{~m}(200 \mathrm{ft})$ below the $\mathrm{SW}$ corner up into the West Lock approach. This eddy is conceptualized on Figure A2. The eddy in the West Lock approach likely prevents direct attack on the SW point by a wide range of CR flows. The North bank of the GIWW between the intersection and the West Lock appears to be experiencing some erosion, probably from the eddy in the West Lock approach. Any alternative that reduces the eddy strength should improve the stability of this bank. Lock personnel noted that during the high water on the CR, the West Lock was opened briefly and the eddy strength and attack of the SW point increased significantly. If the downstream directed velocity attack of the SW point caused the erosion, some type of deflector on the Northwest (NW) corner could be a solution to the erosion problem. With the upstream flows from the eddy being the likely cause of erosion, a deflector at the NW corner would have to be designed in a physical model to have any certainty 
that the eddy strength at the eroding bank did not increase as a result of the deflector.

Even prior to the diversion of the CR, problems were present with GIWW navigation crossing the $\mathrm{CR}$. As flow in the $\mathrm{CR}$ increases, tows have increasing difficulty controlling the head of the tow. The short distance from the intersection to the lock makes it impossible to use a large amount of power to overcome the currents in the river. The problem is more significant for westbound tows because of the shorter distance from the intersection to the lock and because of the angle of the intersecting waterways. When the pilot of a westbound tow realizes he will not make a successful approach to the West Lock, he reduces power and allows the CR currents to push the tow aground on the SW corner. The pilot then rotates the tow around the corner and into the West Lock.

After diversion of the $\mathrm{CR}$, pilots report increased difficulty crossing the CR. Some pilots attribute some or all of this difficulty to erosion of the SW corner and most agree that the SW corner is less suitable as a landing point. The U.S. Army Engineer District, Galveston, asked the U.S. Army Engineer Research and Development Center to make recommendations to achieve the previously stated objective.

\section{Constraints on the Solutions}

The following are constraints on the solutions:

a. The towing industry has made it clear that a hard structure like a mooring cell would result in damage to the barges or breaking of wires in the tow because the currents pushing the tow towards the point can be large.

$b$. A traditional riprap revetment is clearly not acceptable because of potential for damage to the barges. Use of small rock to armor the SW corner, even if it could be shown to be stable, is not acceptable because of concern about interference with dredging operations.

c. After tows land on the protected corner, the protection technique must be durable from the effects of the tow rotating around and sliding along the protection. This constraint eliminates most forms of large fabric bags like geotubes because of the high potential for tearing from barges impacting or sliding along the fabric.

$d$. The selected alternative must not interfere with the occasional tow that enters or exits the GIWW by turning into or out of the CR north of the GIWW. 


\section{Information Sources}

Contacts were made to numerous Corps Districts to find out if they had experienced a similar situation with a navigation channel crossing a river or if they had experience with a fender design that would be suitable for placement at the SW corner for the tows to land on. The Corps' Marine Design Center in Philadelphia, PA, was contacted for information on fendering. The Federal Highway Administration was contacted to see if any techniques used in protecting bridge piers from vessel impact would be suitable as a landing device at the SW corner. Also contacted were marine fender venders, several recommended the donut fender discussed subsequently.

\section{Possible Alternatives}

\section{Periodically rebuild point with dredged material (Figure A3)}

The point could be rebuilt using material from dredging the channel adjacent to the Southeast corner or the material at the mouth of the CR. Since significant erosion occurs only infrequently at high flows, the placed dredged material, depending on its characteristics, should be relatively stable for low and intermediate flows. If material proves to be too easily moved, alternate materials with a significant percentage of clay to increase erosion resistance should be considered, particularly at the point where erosive forces may be greatest. In conjunction with this solution, some type of soft dike could be installed perpendicular to the bank extending out from the West bank below the SW corner to break up the eddy action along the eroding SW corner. ${ }^{1}$ Location of the dike on the west bank of the dredged channel would probably require more study in the physical navigation model. It would have to be far enough upstream toward the corner to effectively intercept the eddy which would likely place it in a critical location where tows would have to land on this dike. This means that a suitable material would have to be found for the dike itself, subject to many of the same constraints as the corner. Another alternative in conjunction with using dredged material to rebuild the corner would be further study in the navigation model to find devices (such as deflector dikes at the NW corner) that reduce the attack of the flow on the SW corner that would prolong the life of the dredged material. Movement of the CR channel toward the left bank could reduce the eddy strength and prolong the life of the dredged material.

\section{Protect point with stable materials that tows can land on}

a) A dike could be built out of small sandbags from existing land to the original location of the SW corner as shown in Figure A4. The arrangement in Figure A4 should significantly reduce the strength of the eddy, particularly along the eroding bank. The sandbags would have to be made of a more durable

\footnotetext{
${ }^{1}$ Personal Communication, Capt. Marvin Reid, Coastal Towing.
} 
material than standard sandbags such as the material used in geotubes. Some movement of bags will occur during impact and maintenance will be required. b) A variation of this alternative is to construct most of the dike out of a geotube and only use sandbags on the nose of the dike. c) Alternately, line both sides of the SW corner with geotubes and place a mound of smallsand bags at the corner up against the geotubes that protrude far enough to ensure that tows will land on the mound of sandbags as shown in Figure A5. The small sandbags will shift during impact, some may rupture, and periodic maintenance of the sandbags will be required. This alternative could be used in conjunction with a rock revetment in the dredged channel along the West bank beginning about $60 \mathrm{~m}(200 \mathrm{ft})$ below the corner and extending downstream to the lower limit of erosion.

\section{Provide landing structure at SW corner so any protection can be used}

This landing structure would be some type of shock absorbing fender at the SW corner and could be used in conjunction with lining each side of SW corner with geotubes or possibly traditional methods like riprap revetment. Since the angle of the tow striking the fender will vary, it will be difficult to design a fender that will spread the impact force along more than one impact point. Shock absorbing "donut" fenders are one possibility. These fenders slide over a circular pile of up to $1.5 \mathrm{~m}$ - (60 in.-) diameter, float with changing water levels, and rotate as tows slide along the fender. The donut fenders are foam filled with a tough outer covering. Figure A6 shows a likely location for the donut fender. Donut fenders up to $4.2 \mathrm{~m}$ (13.75 ft) in diameter are available and deflect about $0.5 \mathrm{~m}(1.5 \mathrm{ft})$ based on information provided by one donut fender vender. This amount of deflection can result in large forces on the tow and on the donut depending on the tow size, speed, flow velocity, and where along the tow the impact occurs. A single donut fender by itself may not provide enough shock absorption and alternate designs could be used as shown in Figure A7 to increase the deflection during the process of stopping the tow and consequently, reduce the force on the tow. The Figure 7 designs are simply concepts that would have to be implemented by an experienced fender designer. Figure A7a shows a donut fender on a pivot frame that is constrained by a spring/shock absorber. The donut fender rotates and floats with changing water levels on a circular pile at the end of the pivot frame. Figure A7 uses the same pivot frame and replaces the spring with another donut fender on a fixed circular pile which allows the donut to rotate and float with changing water levels. Deflection of the Figure A7b design would be about three times that of a single donut fender. The design in Figure A7c was described by a vendor of marine fenders who saw this concept presented at a conference. His recollection was that it had been used on a railroad bridge on the Red River. Several Red River points of contact were asked, but no one knew about this installation. The design employs a heavy object suspended from above. As the tow impacts the object, the objects inertia and the lateral force that increases with deflection of the object act to stop movement of the tow. Rubber cushioning around the object would reduce shock at the initial impact. A design using a donut fender around the suspended object is another variation of this alternative. One marine fender vender suggested the 
"bumpers" used at many docks which are a cylinder of foam with the axis of the cylinder horizontal as shown in Figure A7d. The advantage of these devices is that they deflect up to 85 percent of their diameter because they are loaded from the ship on one side and the back support panel on the other side and have no interior cylinder like the donut fenders. Problems with this design at CR are ability to address changing water levels and potential problems with tows sliding along the device.

\section{Solve navigation problem so any protection can be used}

To address the navigation problem, one possible solution is to place donut fenders along the desired path of the tow across the intersection as shown in Figure A8. The first donut would be positioned outside the main flow in the CR so that the tow can get against the donut before the river flow exerts a significant force on the tow. The tow would then slide along the donut fenders, which rotate, to the lock on the other side of the CR. The 60-m (200-ft) spacing shown on Figure A8 would depend on what vessel length the system was designed for. The alignment shown on Figure A8 is along the south wall of each lock. The line of donut fenders could possibly be placed further south by up to about $22.86 \mathrm{~m} \mathrm{(75} \mathrm{ft)} \mathrm{because} \mathrm{once} \mathrm{the} \mathrm{stern} \mathrm{of} \mathrm{the} \mathrm{last} \mathrm{barge} \mathrm{gets} \mathrm{off} \mathrm{the} \mathrm{middle} \mathrm{donut}$ fender, the CR currents will rotate the head of the tow toward the lock entrance. Capt. Marvin Reid of Coastal Towing, showed this alternative to several pilots who expressed concern about the tow being pinned against the piling in a current that could lead to the tow capsizing. The pilots were also concerned about the ability of the occasional tow that uses the CR to navigate past the line of donut fenders.

\section{Recommended Alternatives}

Of the alternatives presented, the option of placing dredged material on the SW corner should be considered before any structural alternatives such as sandbag dikes or fenders. The life of the sandbag dikes and the uncertainty of the fenders being able to withstand extreme tow impact events are the basis for recommending the nonstructural alternative. In addition, any fender scheme will have the tow pinned against the fender by the flow which presents concerns about capsizing to the pilots. Placement of the dredged material rebuilds the corner to about its original shape and may result in improved navigation conditions. If the dredged material is rapidly removed by flow forces or if environmental restrictions prevent its use, the sandbag dike should be considered along with a maintenance plan to periodically add bags to the nose of the structure. If a fender design is considered, it is recommended that the Corps' Marine Design Center in Philadelphia and/or a marine fender consultant be retained and data from the physical navigation model be used to design the structure.

If you have questions, please contact Dr. Stephen T. Maynord at (601)6343284 or Mr. Charles Nickles at (601)634-3338. 


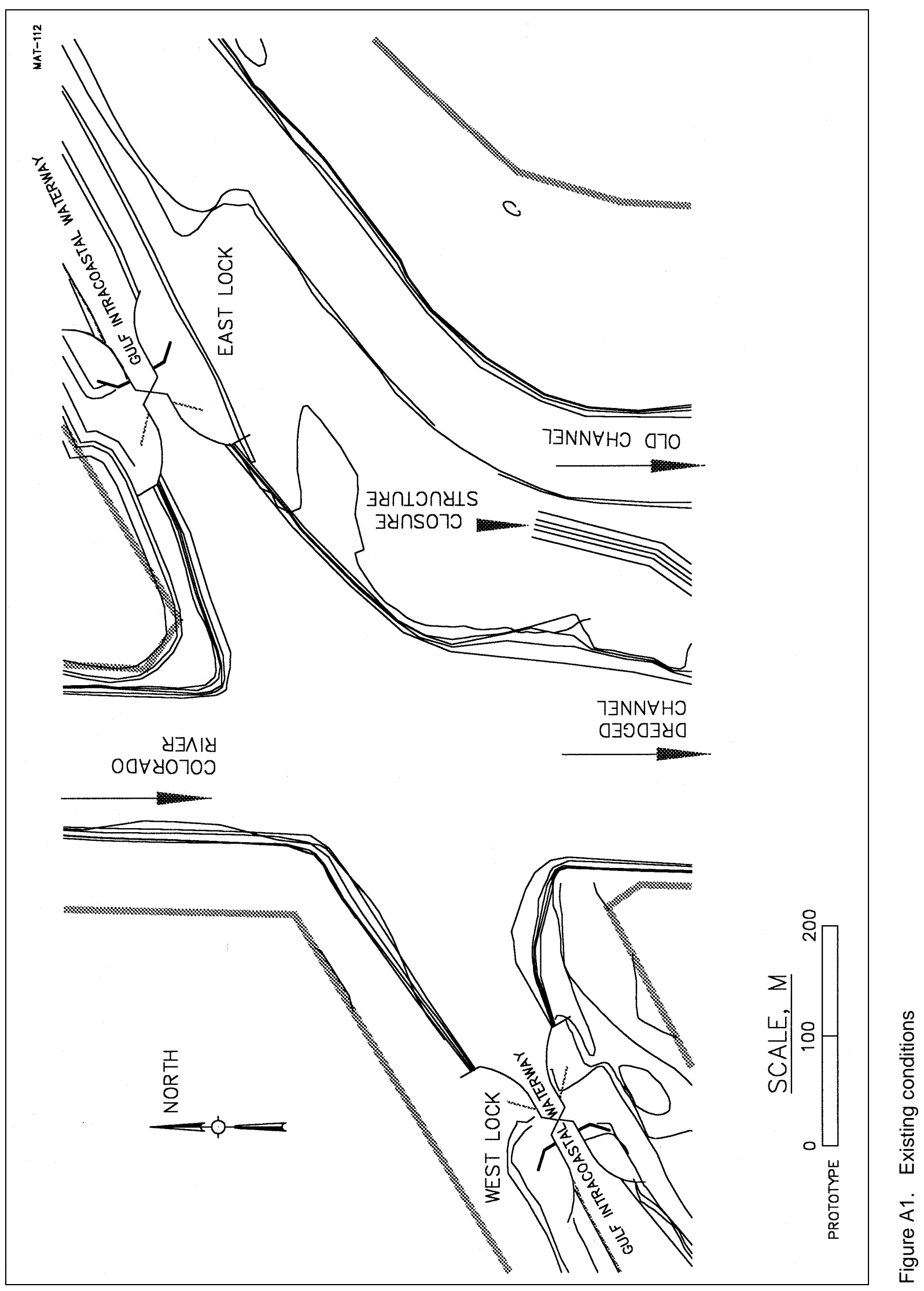




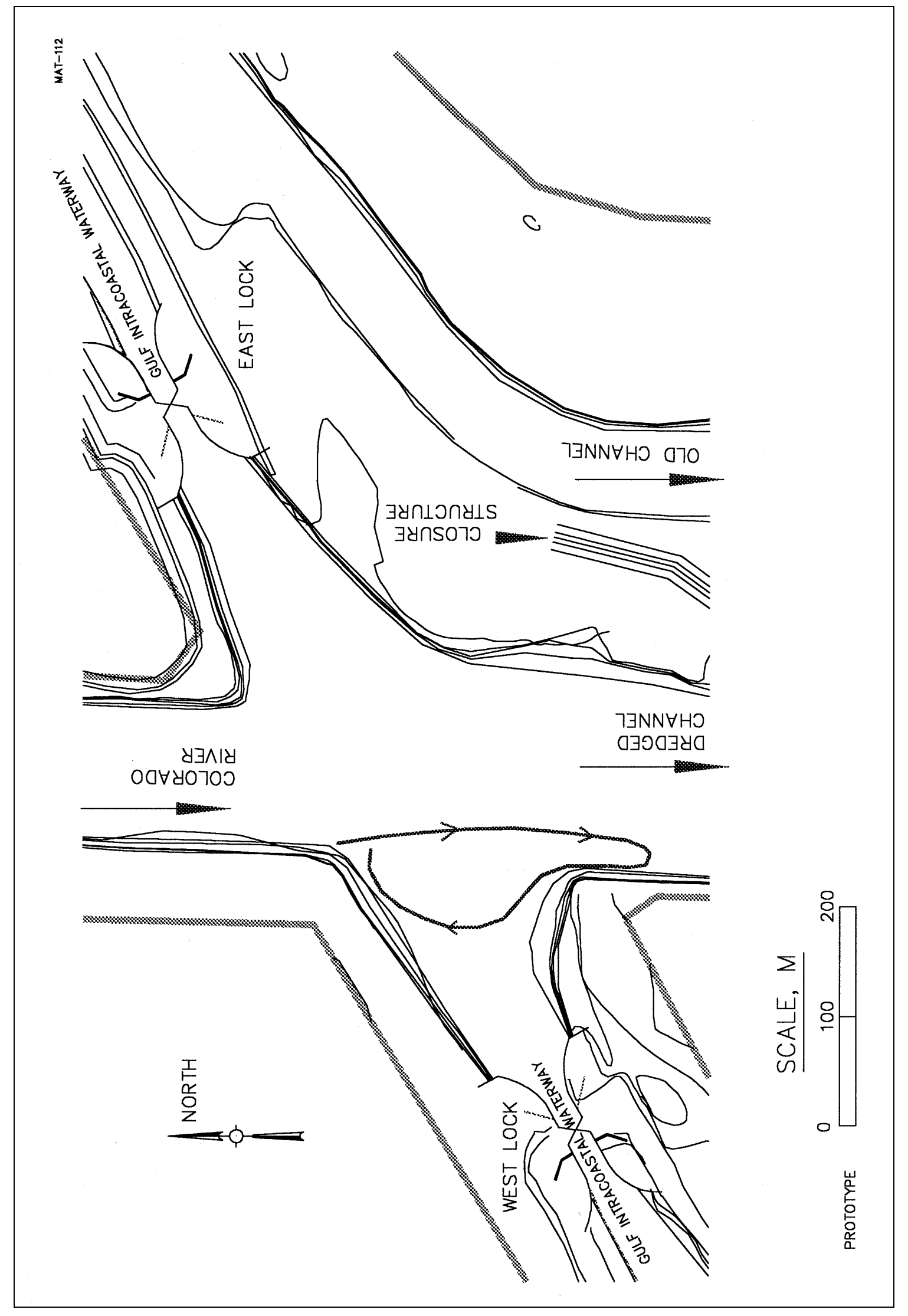

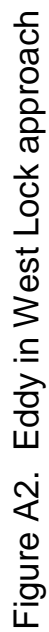




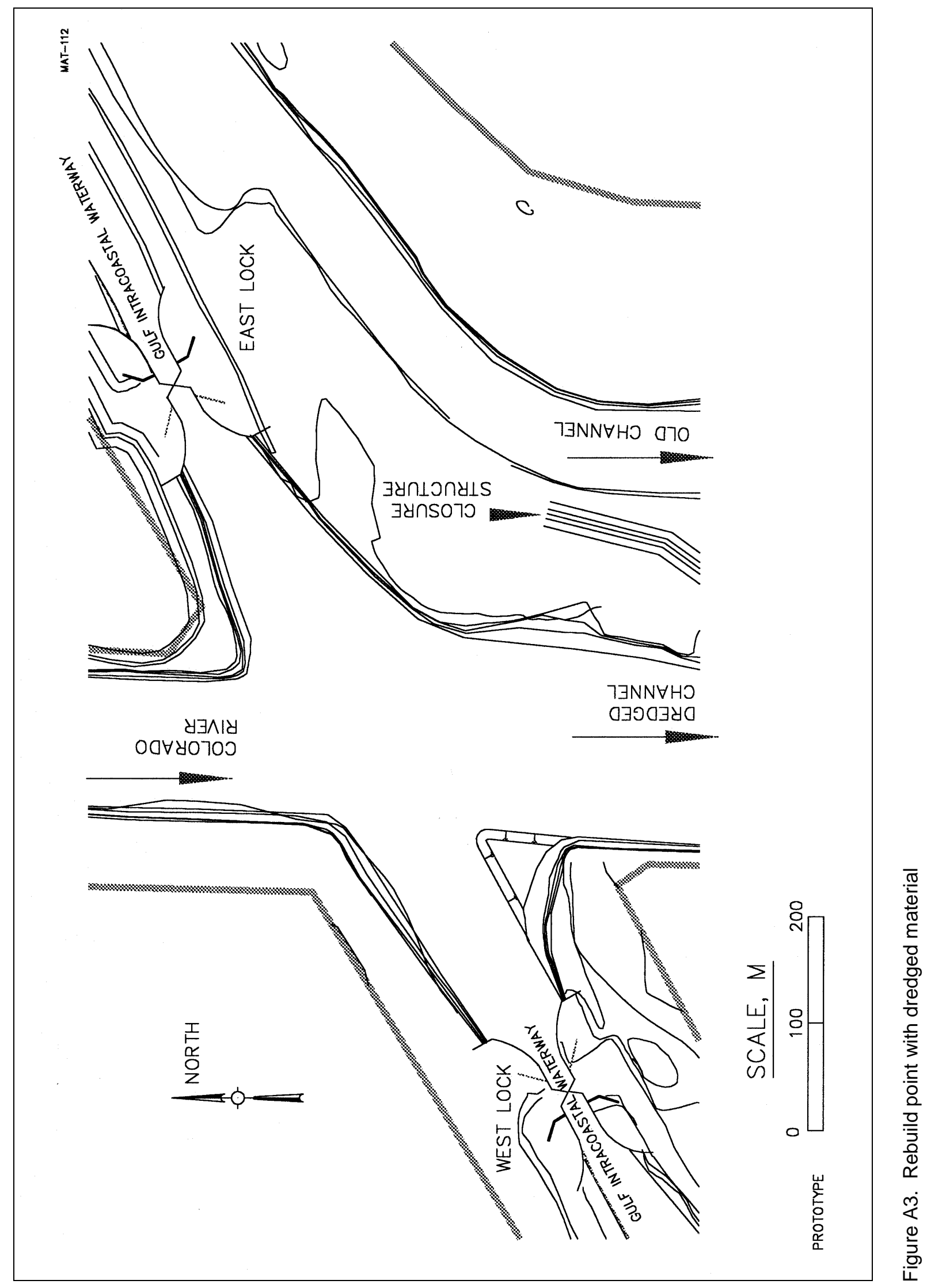




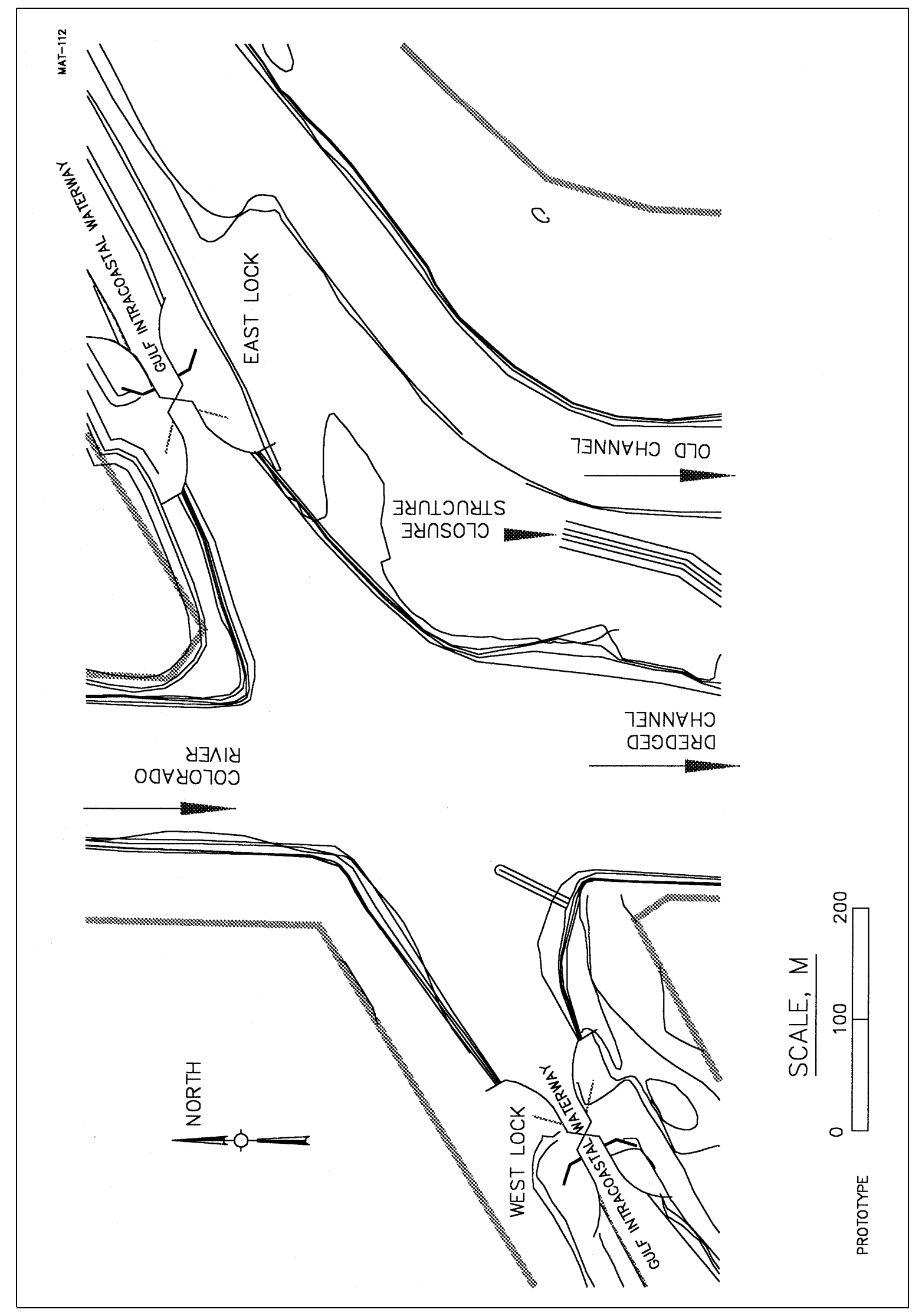

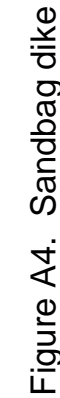




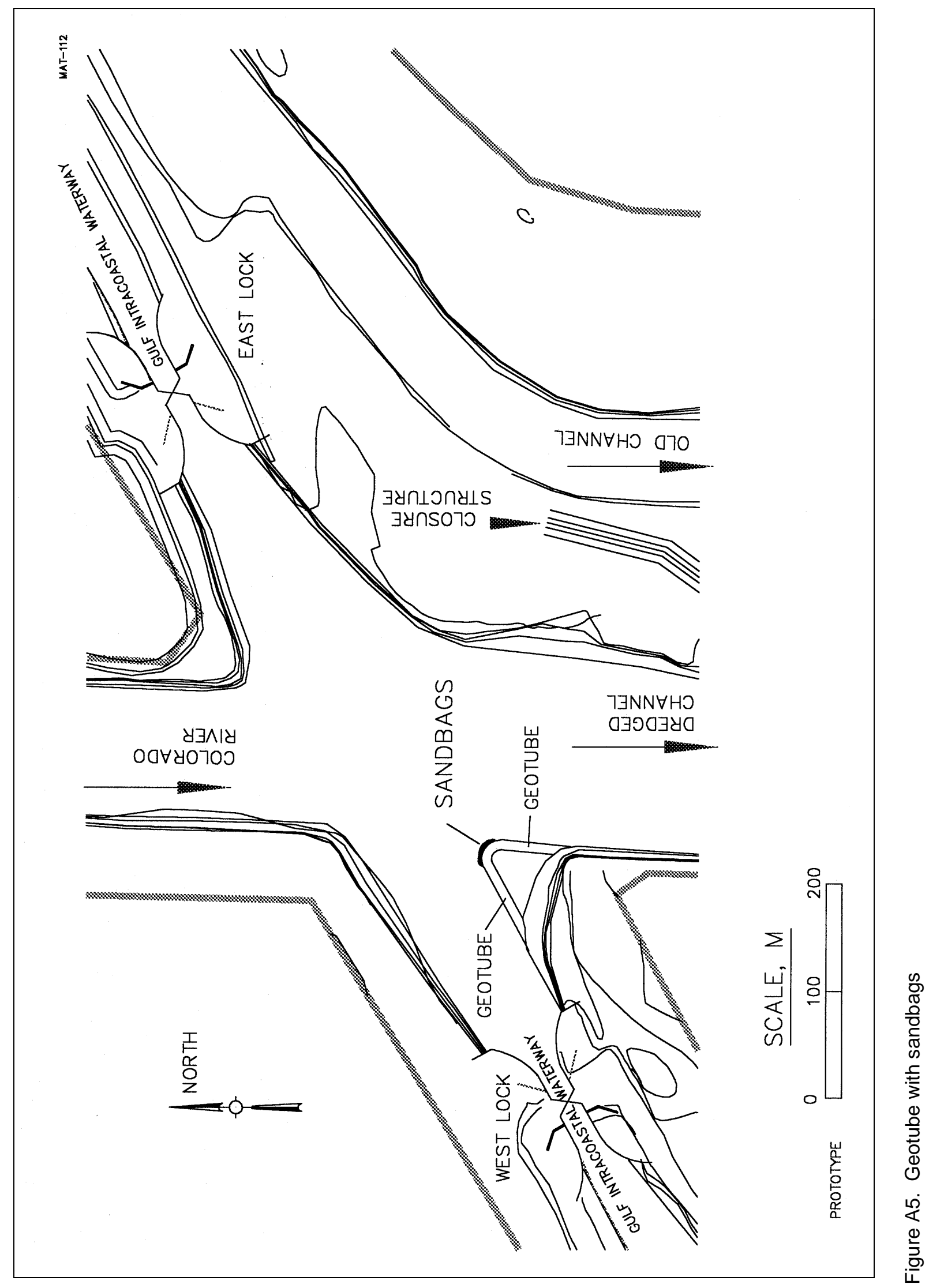




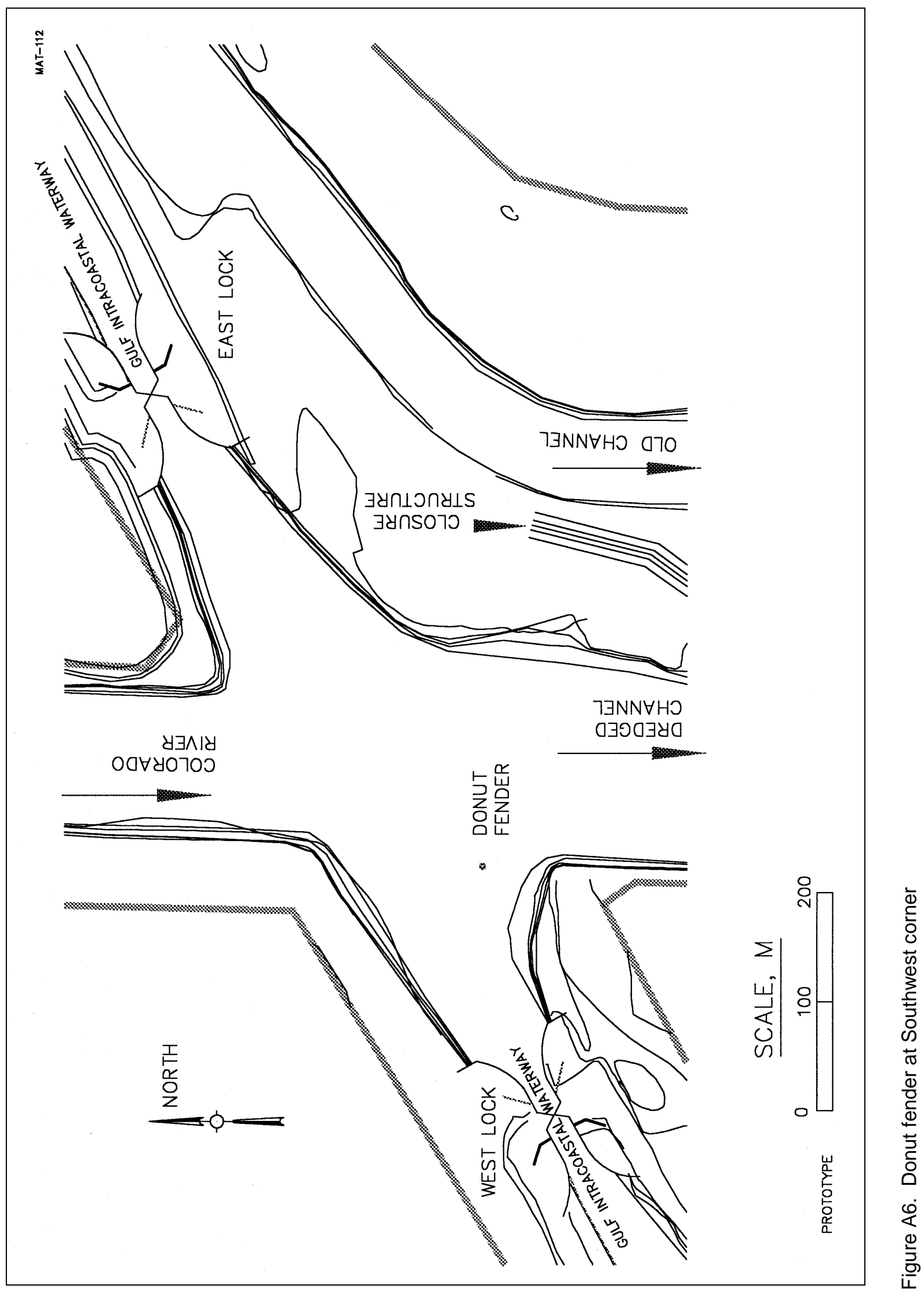

Appendix A Colorado River Southwest Corner Stabilization 


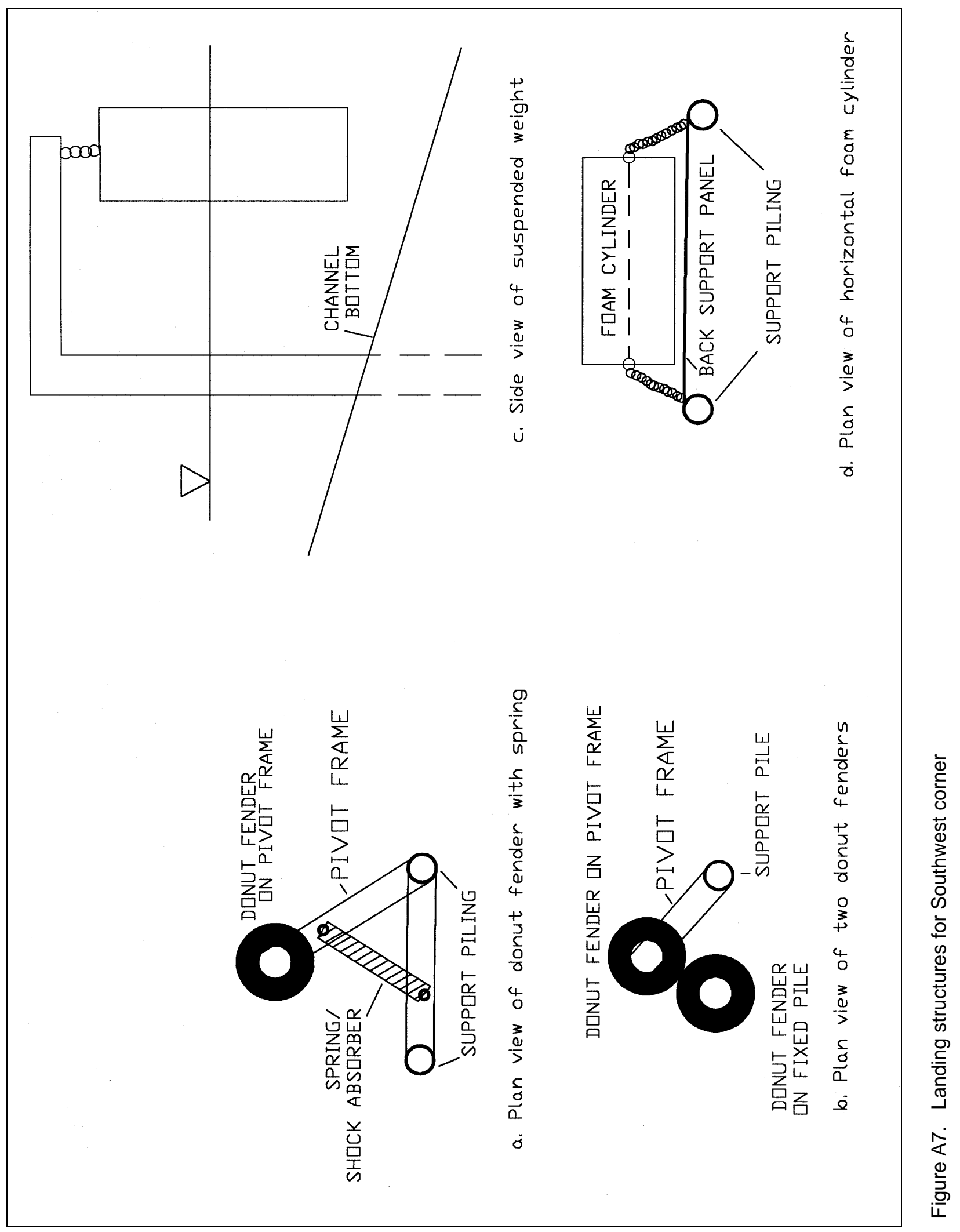




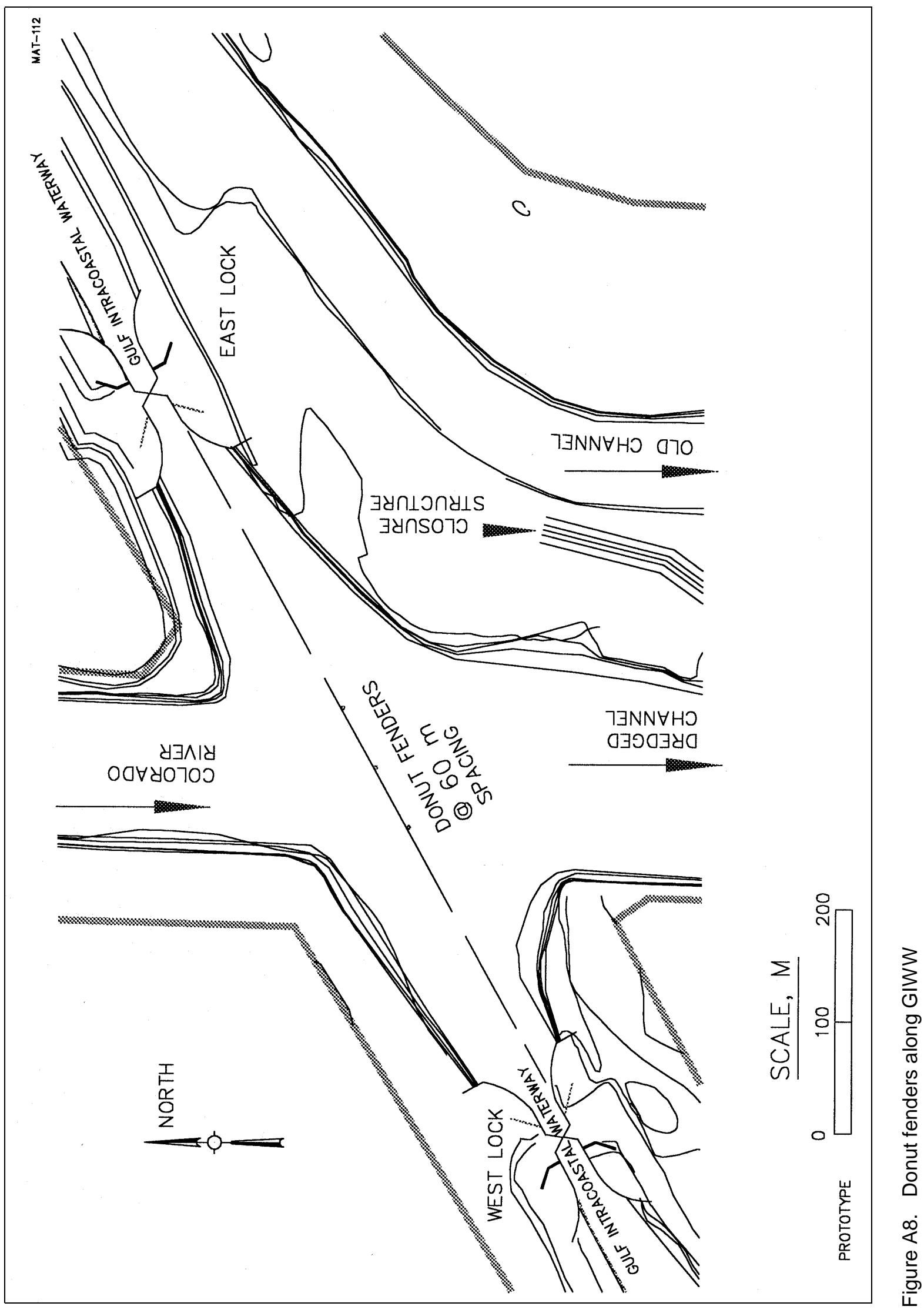

Appendix A Colorado River Southwest Corner Stabilization 


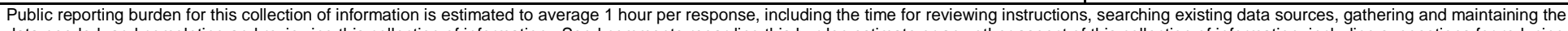

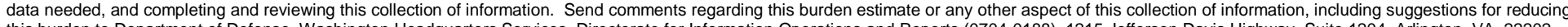

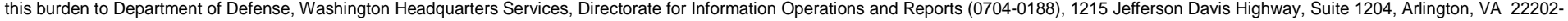

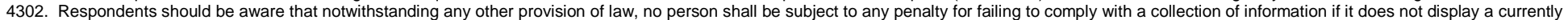
valid OMB control number. PLEASE DO NOT RETURN YOUR FORM TO THE ABOVE ADDRESS

\begin{tabular}{l|l|l} 
1. REPORT DATE (DD-MM- $Y Y Y Y)$ & 2. REPORT TYPE & 3. DATES COVERED (FrOm - TO)
\end{tabular}

November 2000 Final Report

4. TITLE AND SUBTITLE

Navigation Study, Colorado Locks, Colorado River, Matagorda, Texas

5a. CONTRACT NUMBER

b. GRANT NUMBER

5c. PROGRAM ELEMENT NUMBER

6. $\operatorname{AUTHOR}(\mathrm{S})$

Randy McCollum

5d. PROJECT NUMBER

5e. TASK NUMBER

5f. WORK UNIT NUMBER

8. PERFORMING ORGANIZATION REPORT NUMBER

U.S. Army Engineer Research and

Development Center

ERDC/CHL TR-00-26

Coastal and Hydraulics Laboratory

3909 Halls Ferry Road

Vicksburg, MS 39180-6199

9. SPONSORING / MONITORING AGENCY NAME(S) AND ADDRESS(ES)

10. SPONSOR/MONITOR'S ACRONYM(S)

U.S. Army Engineer District, Galveston

P.O. Box 1229

Galveston, TX 77553-1229

11. SPONSOR/MONITOR'S REPORT NUMBER(S)

12. DISTRIBUTION / AVAILABILITY STATEMENT

Approved for Public Release; distribution is unlimited.

\section{SUPPLEMENTARY NOTES}

\section{ABSTRACT}

A 1:70 physical navigation model was built to replicate the Matagorda Locks, approximately one mile of the GIWW east of the locks, approximately one-half mile of the Colorado River north of the GIWW, approximately one-half mile of the Diversion Channel south of the GIWW, and the Bypass Channel connecting the GIWW with the old Colorado River Channel. This report describes plans evaluated with this model to improve navigation through the Colorado River-GIWW intersection and also the GIWW as it passes the opening to the Bypass Channel.

\section{SUBJECT TERMS}

Bypass Channel

Colorado River

Diversion Channel

GIWW

Navigation

Colorado Locks Diversion

\begin{tabular}{|c|c|c|c|c|c|}
\hline \multicolumn{3}{|c|}{ 16. SECURITY CLASSIFICATION OF: } & \multirow{2}{*}{$\begin{array}{l}\text { 17. LIMITATION } \\
\text { OF ABSTRACT }\end{array}$} & \multirow{2}{*}{$\begin{array}{l}\text { 18. NUMBER } \\
\text { OF PAGES }\end{array}$} & 19a. NAME OF RESPONSIBLE PERSON \\
\hline $\begin{array}{l}\text { a. } \text { REPORT } \\
\text { UNCLASSIFIED }\end{array}$ & b. ABSTRACT & $\begin{array}{l}\text { c. THIS PAGE } \\
\text { UNCLASSIFIED }\end{array}$ & & & $\begin{array}{l}\text { 19b. TELEPHONE NUMBER (include area } \\
\text { code) }\end{array}$ \\
\hline
\end{tabular}

